\title{
WestVirginiaUniversity
}

THE RESEARCH REPOSITORY @ WVU

Graduate Theses, Dissertations, and Problem Reports

2012

\section{Vending Vice: The Rise and Fall of West Virginia State Prohibition, 1852-1934}

\author{
Michael J. Buseman \\ West Virginia University
}

Follow this and additional works at: https://researchrepository.wvu.edu/etd

\section{Recommended Citation}

Buseman, Michael J., "Vending Vice: The Rise and Fall of West Virginia State Prohibition, 1852--1934" (2012). Graduate Theses, Dissertations, and Problem Reports. 324.

https://researchrepository.wvu.edu/etd/324

This Dissertation is protected by copyright and/or related rights. It has been brought to you by the The Research Repository @ WVU with permission from the rights-holder(s). You are free to use this Dissertation in any way that is permitted by the copyright and related rights legislation that applies to your use. For other uses you must obtain permission from the rights-holder(s) directly, unless additional rights are indicated by a Creative Commons license in the record and/ or on the work itself. This Dissertation has been accepted for inclusion in WVU Graduate Theses, Dissertations, and Problem Reports collection by an authorized administrator of The Research Repository @ WVU.

For more information, please contact researchrepository@mail.wvu.edu. 
Vending Vice: The Rise and Fall of West Virginia State Prohibition, 1852-1934

Michael J. Buseman

\begin{abstract}
Dissertation submitted to the Eberly College of Arts and Sciences

at West Virginia University

in partial fulfillment of the requirements

for the degree of
\end{abstract}
Doctor of Philosophy
in
History

Elizabeth Fones-Wolf, Ph.D., Chair

Paul Rakes, Ph.D.

Ken Fones-Wolf, Ph.D.

Jack Hammersmith, Ph.D.

Ronald Lewis, Ph.D.

Department of History

\author{
Morgantown, West Virginia \\ 2012
}

Keywords: prohibition, temperance, West Virginia, Wheeling, industrialization, Anti-Saloon League

Copyright 2012 Michael J. Buseman 


\title{
Abstract \\ Vending Vice: The Rise and Fall of West Virginia State Prohibition, 1852-1934
}

\author{
Michael J. Buseman
}

West Virginia imposed state prohibition on its citizens on July 1, 1914. While the transition to a dry society was relatively quiet in the days leading up to July 1 , this tranquility belied the sixty-year battle waged between Mountain State "wets" and "drys" over liquor proscription. Beginning in the 1850s among evangelical Protestants, the anti-liquor movement pushed for different levels of alcohol proscription. By the 1880s, drys were pushing for a state prohibitory amendment to the West Virginia Constitution. The legislative efforts of these preprogressive agitators failed on multiple occasions. This political disappointment peaked with the statewide rejection of a prohibition referendum in 1888. In short, while teetotalers were able to secure local and county-level prohibition via ordinances and commission elections and chip away at the saloon trade through incremental adjustments to state liquor law, West Virginia was not yet ready to climb aboard the water wagon.

Around the turn of the twentieth century, Mountain State drys had activated a more sophisticated and well-funded propaganda campaign. The key to this development was the founding of the West Virginia Anti-Saloon League. Better organization was not enough, however, to explain why West Virginians would eventually authorize state liquor proscription in 1912. The Mountain State also experienced a rapid form of industrialization that changed its socioeconomic and political environment. These changes enhanced a philosophical shift from a laissez-faire, Gilded Age sensibility defined by intense political and social localism to an outlook more closely aligned with Progressive-era activism. In other words, before the turn of the twentieth century, West Virginians accepted localized liquor proscription, but tended to avoid more bureaucratic or statewide anti-alcohol fixes. Once industrialization hit and progressivism seeped in, however, Mountain State residents were more likely to accept the idea of imposing their beliefs on their neighbors.

In 1912, West Virginia voters overwhelmingly authorized a constitution amendment providing for statewide prohibition. Unfortunately for drys, in spite of their best efforts at closing off loopholes and plugging the dam, the Mountain State was never as dry as the Yost Law dictated. Bureaucratic inefficiency, corruption, and widespread illicit distilling delegitimized the law in the eyes of many West Virginians. By the time progressivism waned and America entered the Great Depression, most Americans - Mountain State citizens included wanted state and federal prohibition to go away. West Virginians repealed national prohibition in 1933 and the Yost Law in 1934.

The rise and fall of prohibition in West Virginia lends valuable insight and complexity to many of the Mountain State's post-bellum social, economic, and political struggles. "Vending Vice" is the story of the temporary victory of northern industrialization and centralized bureaucracy over southern Bourbon Democracy and localism. This tension existed in numerous 
states during the industrial period, but it was especially noticeable in West Virginia. It is also the story of socioeconomic change and upheaval, and the defensive imposition of middle-class, Protestant values over an increasingly diverse population. In the end, though, it is the story of the breakdown of the progressive impulse after World War I, the collapse of the post-war economy, and the gradual acceptance by most West Virginians - and their government - that liquor can be more than simply a social evil. 
For James, John Paul, MeMe, Mother, and Dr. Fones-Wolf. This didn't happen without you. 


\section{Acknowledgements}

A project of this size and scope never has one creator. I would like to thank anyone and everyone who believed in me, pushed me, reassured me, or listened to me. I would first like to thank my entire dissertation committee. Committee members Dr. Ron Lewis, Dr. Ken FonesWolf, Dr. Paul Rakes, and Dr. Jack Hammersmith focused my analysis, edited my mistakes, and forced me to think about placing "Vending Vice" in a larger (and better) context. I especially want to express my deep gratitude to Dr. Liz Fones-Wolf. Quite simply, this would not have happened without your patience, sincerity, and kindness.

I would like to thank the rest of the faculty in the WVU Department of History. Dr. Katharine Aaslestad, Dr. Matt Vester, Dr. Mark Tauger, and Dr. Robert Maxon always held me to a high standard in their classes. I would like to say thanks to Martha and Becky in the Department of History office. The whole department would come crashing down without you. I would like to express my gratitude to the friends and colleagues I have made and met over the past few years. Chuck Keeney, Jim DePalma, Jeff Leatherwood, Mark Myers, Melinda Hicks Charles Dusch, Jason Roberts, Ken Deitreich, Mehmet Tupeyert, Gene Van Sickle, and Jinny Turman-Deal were always willing to listen (and to put up with my bombastic opinions).

I would like to thank the staff at the West Virginia and Regional History Collection at WVU. The entire staff was always friendly, helpful, and willing to listen to my research updates, even when they were boring. Also, I'd like to express my gratitude to Beth Weinhardt at the ASL Collection at the Westerville Public Library. I appreciate you mining your sources, making sure it was worth the trip to Ohio, and being so friendly once I got there. I also want to thank Dr. Dan Long. Your advice and patient ear helped get me back on track. 
I would like to express my appreciation to my friends and family. James Bostic, John Paul Hill, and Bob Lasnik got me through this by listening to my litany of complaints, concerns, and crises. James, you were always there with a kind word and well-received distraction during our phone calls about Clemson and Miami football. John Paul, thanks for keeping me sane, reading my drafts, and listening to me drone on about the dissertation when you just got done with yours. Your patience and insight kept me working. Bob, you have stood by me through thick and thin. Our political conversations were a welcome relief from the drudgery of research and writing. I would like to thank my grandmother for being there when I really needed her and reminding me that other people and other generations have worked a lot harder than sitting and writing a dissertation. I'd also like to thank my aunts, uncles, and cousins for treating me the same no matter what and being there with an encouraging comment when I needed it most. Finally, I'd like to express my appreciation to my mother. Your accomplishments have always inspired me. 
Table of Contents

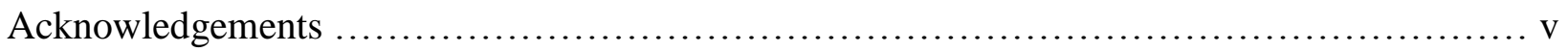

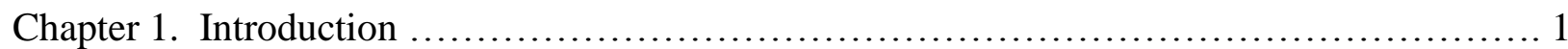

Chapter 2. Stumbling Toward Perfection:

The early Failures of State Prohibition

In West Virginia, 1852-1881 ........................................ 20

Chapter 3. Welding the Phalanx:

Organization, Early Coordination, and the

Road to West Virginia State Prohibition, 1881-1890s ....................... 61

Chapter 4. Drying the Mountains:

Sociopolitical Change, the Anti-Saloon League

Ascendancy, and the Triumph of State

Prohibition, 1890s-1912

Chapter 5. One Step Forward, Two Steps Back:

The Crisis of Enforcement and the Death of

West Virginia State Prohibition, 1913-1934 ........................... 168

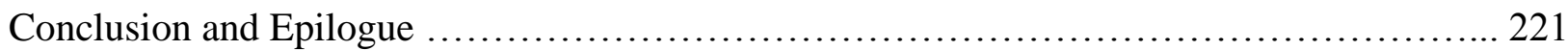

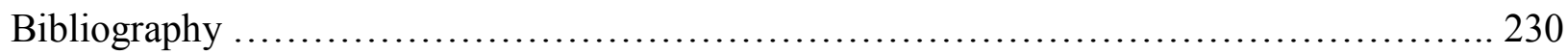




\section{CHAPTER ONE: Introduction}

State prohibition came to West Virginia at the stroke of midnight on Wednesday, July 1, 1914 via the Yost Law. Newspapers across the state ran front-page stories anticipating the momentous event. As the Charleston Daily Mail metaphorically reported the day before the law’s inauguration, "Old Man Barleycorn, who has reigned supreme in West Virginia for the last 50 years ... has about completed the packing of his suit case, and is receiving the greetings and well wishes of his many admirers today."1 West Virginians on both sides of the great prohibition debate reacted to the new law in different ways. Many dry crusaders respectfully celebrated the departure of "Mr. Barleycorn" with their church brethren and fellow moral travelers. The June 30 Daily Mail observed that "in cities and towns throughout the state the prohibition element has arranged for parades, church services and other demonstrations to take place at midnight tonight in celebration of the coming into operation of the prohibition law."2 The Women's Christian Temperance Union (WCTU) in Morgantown commemorated state prohibition by organizing a train ride, gathering, and picnic lunch at a local park. Other Morgantown drys decorated their homes, the city flew flags at the court house, and the millworkers in Sabraton adorned their factory with American flags and were heard "giving numerous cheers during the day."3

Despite the cheers of the drys in Morgantown, the transition to prohibition in West Virginia was relatively quiet overall. In fact, it was hard to tell that such a momentous shift in public policy had even occurred in some West Virginia cities. The evening edition of the July 1

\footnotetext{
${ }^{1}$ Charleston Daily Mail, June 30, 1914.

${ }^{2}$ Charleston Daily Mail, June 30, 1914.

${ }^{3}$ Morgantown Post-Chronicle, July 1, 1914, and Morgantown New Dominion, July 2, 1914.
} 
Parkersburg Sentinel reprinted reports from around the state in the front-page story entitled "Water Wagon Starts Quietly." In Wheeling, home to over 20 percent of the saloons operating in the entire state, "no demonstration marked the closing by the dry forces. No requiems were celebrated over the body of John Barleycorn, deceased." ${ }^{4}$ The muted reaction in Wheeling may have had something to do with the fact that Ohio County was not exactly a dry stronghold during the ballot box battle over state prohibition in 1912. In fact, Ohio joined only two other counties (McDowell and Hardy) in rejecting the constitutional amendment. Ohio County citizens rejected the amendment by greater than a two-to-one margin. ${ }^{5}$ Further down the Ohio River, the situation mirrored that of Wheeling as prohibition closed in on Parkersburg. The Parkersburg Sentinel commented on the eve of the Yost Law that the transition from wet to dry was proceeding "quietly and without disorder." This relative tranquility was the result of, according to the paper, the distributors' decision to prepare for the inevitable and sell off their stock early, especially on the last Saturday before July 1. Additionally, the Sentinel maintained that "the liquor dealers are retiring with good humor. They are all ready to obey the mandate of the law." It seems that even the prohibitionists' former enemies greeted the change with impressive poise.

While dry West Virginians and their former enemies greeted the new law with a mixture of subdued commemoration, stoicism, and maturity, Mountain State citizens not on the water wagon reacted to the ban on the purchase of alcohol by purchasing and consuming an awful lot of alcohol before July 1 . When reading the accounts of the last day of legal liquor in West Virginia, one cannot help but compare this booze rush with the semi-panicked but ultimately

\footnotetext{
${ }^{4}$ Parkersburg Sentinel, July 1, 1914.

${ }^{5}$ John T. Harris, ed., West Virginia Legislative Hand Book and Manual and Official Register, 1916 (rev.) (Charleston, WV: Tribune Printing, 1916), 722.

${ }^{6}$ Parkersburg Sentinel, June 30, 1914.
} 
orderly procession of Floridians entering and exiting hardware stores in search of plywood and generators right before a hurricane. Wet or dry, most West Virginians were aware of how the impending constitutional amendment was worded and how it was designed to operate. As one state newspaper ably summarized, "It will still be lawful for an individual to drink liquors in West Virginia, but it is against the law for him to make it, buy it, sell it or give it away." This meant, in short, that Mountain State drinkers would have to go out of state to secure their favorite beverages after June $30 .^{7}$

While the amendment's structure, at least initially, opened a gaping loophole for West Virginians (especially those on the border), many wets decided to stock up at their local store while the getting was still good. Local workingmen with newly minted paychecks in hand descended upon Moundsville the Saturday night before July 1 in order "to lay in at least a sufficient quantity of wet goods to last them over the Fourth."8 In Charleston, the scene was similar as many saloon owners and dealers cut their prices in order to clear what was left of their stock. The capital city also had its share of local visitors as "hundreds of suit cases bulging with bottles and jugs were carried through the streets of the city yesterday by out-of-town people on their way to the railroad stations after making purchases." The Daily Mail estimated that Charleston-area drinkers would spend around $\$ 40,000$ stocking up during the last two days (a Monday and Tuesday) of the wet regime. ${ }^{9}$ There were also significant runs on alcohol in Clarksburg and Wellsburg in the Northern Panhandle. In fact, this last-minute demand caused many saloons in these towns to close before midnight on the first. Of the eight saloons in

\footnotetext{
${ }^{7}$ Morgantown Post-Chronicle, June 30, 1914. Much more attention will be paid to how the structure of the law worked and, ultimately, undermined state prohibition in chapter five.

${ }^{8}$ Wheeling Register, June 28, 1914.

${ }^{9}$ Charleston Daily Mail, June 30, 1914.
} 
Wellsburg, only two remained open until the last night as the others had already sold their entire stock. Only six of Clarksburg's thirty-four saloons stayed open on the thirtieth as most proprietors had either cleared their shelves or were concerned about disorder as the deadline approached. ${ }^{10}$

In retrospect, these Clarksburg saloon owners had little to fear from West Virginia's thirsty masses as the prohibition amendment went into effect. The vast majority of reports indicate that, in spite of the late run on alcohol, Mountain State residents experienced little upheaval in late June and early July. Perhaps sharing his patrons' collective sense of inevitability and uncertainty about the future, one Charleston saloon owner placed a sign in his window identifying the period before July 1 as "The Last Days of Pompeii." 11 Unlike their ancient Roman cousins, however, most drinking West Virginians mirrored the attitude and behavior of liquor dealers and resisted the temptation to panic. While most cities and towns around the Mountain State inaugurated prohibition in an orderly fashion, the looming law did create a beehive of nervous and sometimes quite comical activity among wet citizens, especially in border towns.

Wheeling was undoubtedly the center of this nervous activity. This city was not only the center of population in the Northern Panhandle, it was also "the brewing capital of West Virginia," as local historian Albert Doughty asserts. ${ }^{12}$ While most prohibition supporters stayed quiet and stayed home as the law approached - apparently satisfied that their work was done procrastinating citizens from all over the northern part of West Virginia and neighboring states

\footnotetext{
${ }^{10}$ Parkersburg Sentinel, July 1, 1914.

${ }^{11}$ Charleston Daily Mail, June 30, 1914.

${ }^{12}$ Wheeling Sunday News-Register, May 30, 2010.
} 
descended upon the "city of lights" in every conceivable conveyance, searching for that lastminute bargain while local residents made sure to visit their favorite establishment for the last time. The final Saturday night before prohibition was, perhaps not unsurprisingly, extremely busy in downtown Wheeling. As the Wheeling Register remarked, "The wholesale stores, as well as the places of business of the retailers, were crowded, even jammed with people bent upon laying in a supply to tide them over." ${ }^{13}$ In spite of the large numbers of Saturday drinkers in the downtown district, the situation remained orderly and relatively tranquil. There were, of course, those who had a few too many, but local papers credited saloon owners for keeping a lid on conditions by remaining "especially solicitous in the matter and ... particularly careful not to allow any trouble to get beyond bounds." Additionally, newspapermen pointed out that the Wheeling Chief of Police handled the big night with considerable conscientiousness. In total, only five arrests were made Saturday night - three came from one fight over a shoe shine, another was the result of domestic assault and the last was for public intoxication. ${ }^{14}$

With the passage of the Yost Law, West Virginia became only the ninth state to impose prohibition on a statewide basis. In fact, West Virginians were the only citizens in the MidAtlantic to institute a dry regime at this point. ${ }^{15}$ Surrounded on all borders by five states where the sale of alcohol was still legal in at least some parts, Mountain State citizens ratified a constitutional amendment nearly six years before the passage of national prohibition. Not only did West Virginians ratify the amendment in 1912, they did so overwhelmingly. The total vote was 164,945 in favor and 72,603 against. The majority of citizens in fifty-two of the state's

\footnotetext{
${ }^{13}$ Wheeling Register, June 28, 1914.

${ }^{14}$ Wheeling Register, June 28, 1914.

${ }^{15}$ The other dry states as of 1914 were Maine, Kansas, North Dakota, Oklahoma, Georgia, Mississippi, North Carolina, and Tennessee; New York Times, June 29, 1914.
} 
fifty-five counties favored the amendment. Ohio (home to West Virginia's brewing industry and significant immigrant and Catholic populations), McDowell (home to a large coal mining industry and significant numbers of Catholics and African Americans) and tiny Hardy were the only counties to vote against prohibition. ${ }^{16}$ Even the New York Times commented on the margin of dry victory in its report on the imposition of the new law: "The 92,000 majority with which the people of West Virginia voted for prohibition was relatively the largest ever given by any state. ${ }^{17}$

The overwhelmingly easy victory of the 1912 amendment coupled with the mostly glowing reports filed by newspapers throughout the state on the eve of the amendment's implementation would suggest that the prohibition movement in West Virginia traveled a relatively smooth and uneventful path to its vision of social perfection. The seeming alacrity with which prohibition prevailed and the tranquil manner in which the transition from a wet to dry society occurred could even suggest that this reform was inevitable. After all, even the Wheeling Intelligencer, the state's leading media voice against prohibition, assumed an attitude of resignation as the new law approached: "There is no use in discussing the merits or objections of the prohibitory law at this time. It was endorsed by a majority of 92,000 voters, and it is up to these persons to decide whether they have done well or unwisely." 18

It is true that statewide prohibition was, in the strictest sense, inevitable by the summer of 1914. It should not be surprising that the Charleston saloon owner hung the sign that he did a few days before he went out of business. Wet elements in West Virginia knew prohibition was

\footnotetext{
${ }^{16}$ Harris, West Virginia Legislative Handbook, 722.

${ }^{17}$ New York Times, June 29, 1914.

${ }^{18}$ Wheeling Intelligencer, June 29, 1914.
} 
coming, and they knew it was coming for the better part of two years. The lag between the ratification of the amendment in the fall of 1912 and its implementation in the summer of 1914 gave the state's 1,200 saloon owners and liquor dealers time to make other arrangements and successfully mitigated the shock and anger that could have been experienced by thirsty West Virginians. According to the Intelligencer, those in the alcohol business "accepted their fate in a philosophical way. Many have already arranged to go into other businesses. Quite a few will leave the city for the time being on tours, but in no instance do they say they will leave Wheeling for good."19 The Republican organ may have overstated the economic pull of a dry Wheeling as another report suggested that "many" simply closed shop and fled the Mountain State. ${ }^{20}$

The experience of West Virginia's wets and drys on the eve of the Yost Law would indeed indicate, in isolation, that the implementation of constitutional prohibition was the simple and inevitable outcome of a well-coordinated and successful reform movement sustained and supported by a cadre of well-connected and influential West Virginians. After all, Mountain State prohibition was ahead of its time both regionally and nationally, citizens approved the referendum in overwhelming numbers throughout the state, the transition was relatively quiet, supporters were largely subdued in their celebrations, and even its strongest opponents seemed to have come to terms with the new law by the summer of 1914. However, the stable and inevitable transition from wet to dry described in newspapers in 1914 belies the real story behind the ultimate success of statewide prohibition. The truth is that, until citizens approved the referendum in the fall of 1912, the path to this particular vision of social perfection was far from clear and even further from inevitable.

\footnotetext{
${ }^{19}$ Wheeling Intelligencer, July 1, 1914.

${ }^{20}$ Morgantown Post-Chronicle, July 1, 1914.
} 
The triumph of state prohibition was the result of a vicious sixty-year campaign in which wets and drys campaigned for what they each considered their moral, political, and economic survival. The battle over this issue was the social version of trench warfare; it was never the blitzkrieg that it appeared to be in the hindsight of 1914 media reports. The words of one historian describing the fate of national prohibition later in the century are applicable to West Virginia: "Dramatic as the incidence of prohibition appears, it was not sudden. It was the culmination of a century of agitation." 21 In the case of the Mountain State, the organized movement to ban alcohol began in the evangelical Protestant churches over a decade before West Virginia even achieved statehood. The seemingly blasé reactions to the Yost Law were the result of absolute exhaustion on both sides of the issue. As one reporter pointed out, "The fight stretches over a wide period of years, during which both the dry and wet factions expended every effort for victory."22

As triumphant as the prohibition movement may have appeared in the summer of 1914, the truth is that drys had lost far more statewide battles than they had won in the decades leading up to the Yost Law. For most of the second half of the 1800 s and into the early $20^{\text {th }}$ century, West Virginia prohibitionists looked as if they had embarked on a hopeless, almost quixotic, quest to eliminate what they considered to be a great evil from the public square. Religious leaders and followers, a few businessmen, and some dry politicians preached temperance from the pulpit, constantly flooded the state senate and House of Delegates with prohibitionist petitions, and regularly submitted bills calling for state prohibition. In spite of this constant pressure, wet forces almost always tipped over the water wagon. Even when drys seemed to

\footnotetext{
${ }^{21}$ Sean Dennis Cashman, Prohibition: The Lie of the Land (New York: The Free Press, 1981), 2.

${ }^{22}$ McDowell Recorder, July 3, 1914.
} 
make some political headway and threaten the existence of legal liquor, they still lost.

Prohibitionists experienced near misses with their legislation on three occasions in the 1880s alone. The 1920 dry publication, The Evolution of Prohibition in the United States of America, lamented that "submission of an amendment failed for lack of four votes [in the Senate] ... in 1881. In 1883 a similar resolution passed the house but was defeated in the senate. The legislature of 1888 took favorable action but the amendment was defeated by . . the people."23 Bills, resolutions, amendments, and referenda aimed at restricting or eliminating the liquor trade appeared on many Senate and/or House agendas between 1863 and 1911 - the vast majority of these attempts failed. Ultimately, then, the first almost fifty years of organized prohibitionist activism is a story of disappointment, near misses, and failure.

In some ways, the Mountain State's early forays into liquor proscription follow more general, national trends. West Virginia failures in the 1870s and 1880s mirrored failures all over the United States. Only five states adopted prohibition in the 1870 s and only three of those, Maine, Kansas, and North Dakota, actually retained their laws. ${ }^{24}$ While the early movement in West Virginia flirted with success and ultimately failed on numerous occasions during the 1880s, dry citizens of other states also tasted defeat. According to historian Ann-Marie Szymanski, citizens in twelve states rejected referenda on constitutional prohibition between 1882 and 1890, revealing in the eyes of Szymanski a "lack of grassroots support for statewide prohibition." Similar to the 1870 s, the only states to authorize referenda or retain some form of statewide prohibition remained in the heavily Protestant and racially homogeneous upper New England

\footnotetext{
${ }^{23}$ Ernest H. Cherrington, ed., The Evolution of Prohibition in the United States of America: A Chronological History (Westerville, OH: American Issues Press, 1920), 178. Not only did the 1888 amendment fail, it failed by a majority of over 34,000 votes as only a few, mostly rural counties voted to go dry. Morgantown Post-Chronicle, November 6, 1912.

${ }^{24}$ David E. Kyvig, Repealing National Prohibition (Chicago: University of Chicago Press, 1979), 6.
} 
and Midwest regions. The nineteenth-century struggle for liquor proscription began to lose steam at the beginning of the 1890s. ${ }^{25}$ The flurry of prohibitionist action in the West Virginia Legislature also began to decline at roughly the same time. Historian Jack Blocker considers the 1890s to be "a period of failure for prohibitionists, an interlude of frustration" between the 1880 s and the first and second decades of the $1900 \mathrm{~s}^{26}$ It was in the first decade of the twentieth century that Mountain State drys began enjoying some success. Even then, these triumphs tended to take the form of minor and incremental adjustments to state law and liquor regulation. $^{27}$

As important as it is not to overstate the triumph of statewide prohibition in 1912, it is just as crucial not to paint the entire early movement against liquor as a complete failure or completely parallel to national trends. It is true that, in the purest sense, early agitation for statewide prohibition was a failure as the desired outcome was not attained. Local efforts, however, suggest that there was some anti-liquor progress in the late 1800s and very early 1900s. Thirty West Virginia counties were dry by $1906 .{ }^{28}$ In 1881 , at the height of the early political agitation for the statewide prohibition of alcohol, the number of teetotaler counties peaked at 39. ${ }^{29}$ Social commentators of the time and later historians incorrectly traced these outcomes to

${ }^{25}$ Ann-Marie Szymanksi, Pathways to Prohibition: Radicals, Moderates, and Social Movement Outcomes (Durham, NC: Duke University Press, 2003), 2-3.

${ }^{26}$ Jack S. Blocker, Retreat from Reform: The Prohibition Movement in the Unites States, 1890-1913 (Westport, CT: Greenwood Press, 1976), 6.

${ }^{27}$ These minor laws mainly passed between 1890 and 1909 and imposed or amended a number of incremental regulations (civil damage laws, Sunday closing, sales to minors, etc.) on liquor. Much more detail will be provided on these reforms in chapter four.

${ }^{28}$ Cherrington, Evolution of Prohibition, 256; there is some debate over this figure as James Timberlake asserts that "more than one-half" of West Virginia's counties were dry by 1908. James H. Timberlake, Prohibition and the Progressive Movement (Cambridge, MA: Harvard Press, 1963), 150.

${ }^{29}$ West Virginia Freeman, July 6, 1881. 
countywide local option votes. West Virginia citizens did not possess the right of local option elections as the state Republican Party was still calling for the passage of such a right in their 1908 platform. ${ }^{30}$

In reality, successful attempts at local and countywide prohibition before 1912 were considerably more ad hoc in nature. The most common strategy used by prohibitionists was to insure that county court judges, clerks, and commissioners were sympathetic to their cause. According to the Anti-Saloon League, "The constitution of West Virginia empowers the county commissioners to grant or refuse liquor licenses."31 For example, the New Cumberland Independent explained in 1907 that "the [liquor] question has never been submitted to a vote of the people, and under the law, the county court if so disposed, is authorized to grant liquor licenses." ${ }^{32}$ Had the Hancock County clerk decided to grant liquor licenses, he would have most likely been in considerable political trouble. The Northern Panhandle county was one of the very few locales to back state prohibition during the 1888 referendum. ${ }^{33}$

Residents of Mountain State towns and cities also had the option of banning alcohol via more localized ordinances before the imposition of state prohibition. As the ASL pointed out in its 1908 year book, "The Legislature grants to the councils of certain towns and cities the right to grant licenses."34 Some cities in West Virginia's northern coalfields had prohibitionist local ordinances in the late nineteenth and early twentieth century. However, these local laws were

\footnotetext{
${ }^{30}$ Gary J. Tucker, "William E. Glasscock: Thirteenth Governor of West Virginia” (PhD diss., West Virginia University, 1978), 26.

${ }^{31}$ Ernest H. Cherrington, ed., The ASL Yearbook: An Encyclopedia of Facts and Figures Dealing with the Liquor Traffic and the Temperance Reform, Volume 1 (1908) (Columbus, OH: ASL Publishing, n.d.), 192.

${ }^{32}$ New Cumberland Independent, September 19, 1907.

${ }^{33}$ Morgantown Post-Chronicle, November 6, 1912.

${ }^{34}$ Cherrington, The ASL Year Book, 1908, 192.
} 
not written in stone and were sometimes subject to the fluid political attitudes of changing populations. Established families in Fairmont, for example, were concerned that the 1890s growth of manufacturing plants in the area and the subsequent increase of immigrant workers would endanger their city's anti-liquor laws. ${ }^{35}$ Increasing numbers of Catholic workers actually changed prohibition laws in Clarksburg. New immigrant voters overturned the city's local prohibition ordinance in $1905 .^{36}$ If Mountain State teetotalers wanted to ban alcohol before the imposition of the Yost Law, they had to do it either indirectly through choosing dry county officials or locally in their own towns and cities. They never enjoyed the right to call countywide local-option elections. ${ }^{37}$

The experiences of Marion and Harrison County residents lend valuable insight into the overall narrative of West Virginia's early prohibition movement. Just as Clarksburg's dry elements learned in 1905, success was far from guaranteed in the early days. Triumph never followed an upward track in West Virginia. Success at the state level was never just a matter of time, especially before 1912. Early agitators faced setback after setback. There would be local victories and, as we know, some legislative lurches forward, but the movement always progressed in fits and spasms. Additionally, as Clarksburg and Fairmont show, Mountain State crusaders would not have the luxury of preaching primarily to a white, Anglo-Saxon, Protestant choir. West Virginia was not populated only by old-stock Protestants like Upper New England

\footnotetext{
${ }^{35}$ Ken Fones-Wolf, Glass Towns: Industry, Labor, and Political Economy in Appalachia, 1890-1930s (Urbana: University of Illinois Press, 2007), 155.

${ }^{36}$ Fones-Wolf, Glass Towns, 126.

${ }^{37}$ In fact, the state senate rejected county local option in 1909; only one session before the passage of the prohibition referendum on to the people. Ernest H. Cherrington, ed., The ASL Yearbook: An Encyclopedia of Facts and Figures Dealing with the Liquor Traffic and the Temperance Reform, Volume 3 (1910) (Westerville, OH: American Issue Publishing, n.d.), 83.
} 
was; it was not largely rural and Protestant like the Midwest (save larger cities like St. Louis and Chicago); it was not a racially controlled and ultimately evangelical democracy like the Deep South. The Mountain State was becoming black and white, urban and rural, native and immigrant, and Protestant and Catholic by the late nineteenth century - this would make selling a dry society that much more difficult. While the true believers were never able to impose their beliefs on the increasingly complex citizenry of the Mountain State between 1852 and 1912, they were successful in laying the groundwork for their eventual victory. It was in these lean years that dry and wet drafted their battle plans, crafted their arguments, rallied their forces, and skirmished.

Chapter two, entitled "Stumbling toward Perfection," is the first act of a story of failure, but it is also when the economic, moral, political, and social arguments that would inform the centuries-long battle over vice and its proper place in West Virginia society first emerged. It is, in short, the end of the beginning. West Virginians in the mid and late nineteenth century were simply not ready for state prohibition. Mountain State drys, on the other hand, were not ready to surrender - even after their failed legislative attempt at state prohibition in 1881. "Welding the Phalanx" (chapter three) covers the last two decades of the nineteenth century. With the exception of some minor, incremental adjustments to the liquor law, Mountain State drys continued to experience political frustration in the 1880s and 1890s, highlighted by the overwhelming rejection of a prohibition referendum in 1888. The Anti-Saloon League (ASL) was not yet active in the area and West Virginia had not yet undergone the unsettling sociopolitical changes necessary to activate prohibitionist sentiment in the majority of citizens. However, prohibitionists never succumbed to their seemingly endless series of legislative 
defeats. They soldiered on and settled on a strategy that would eventually lead to the victory of state liquor proscription, once the field was more fertile for such a progressive experiment.

Chapter four, "Drying the Mountains," details the last few years of the nineteenth century through the triumph of a state prohibition amendment during the 1912 election. The rise of the West Virginia Anti-Saloon League and its advanced organizational and fundraising infrastructure provided drys the political strength necessary to realize the potential of their new, gradualist strategy. This approach slowly tightened the regulatory noose around wets, effectively making them vulnerable enough to defeat in 1912. Of course, undecided West Virginians would never have sided with their teetotaler neighbors at the ballot box without fundamental transformations to their social, political, and philosophical surroundings. These changes were enough to scare swing voters away from the saloon and towards a supposed dry utopia. "One Step Forward, Two Steps Back" (chapter five) shows that, while the Mountain State may have been technically dry, it was far from a utopia after 1912. Lawmakers fought a defensive, and ultimately unsuccessful, battle against the Yost Law's regulatory shortcomings, the unwillingness of the majority of citizens to enforce the law, and the willingness of some to violate it. The state never convinced enough citizens that state (and, after 1919, national) liquor proscription worked. Consequently, when progressivism faded after the end of World War I and the economy crashed in 1929, politicians and their constituents were ready for a change. Mountain State citizens repealed national prohibition in 1933 and the Yost Law in 1934. Legislators replaced prohibition with a state liquor monopoly in 1935. This state found itself in the role of vice vendor for the first time. This role would only expand by the late twentieth and early twenty-first centuries.

Initial studies of the national prohibition movement focused on retroactively defending the repeal of the Eighteenth Amendment. According to Blocker, "prohibitionists were studied 
because of their freakishness, their differences from 'ordinary' people." This first historiographical wave's “capstone was Andrew Sinclair's Era of Excess, which pictured prohibitionists as rural fanatics and their crusade as a social aberration, a manifestation of extremism provoking extremism in return." ${ }^{38}$ Blocker argues that a "second phase" of prohibition studies emerged in the early to mid 1960s. Through works like Prohibition and the Progressive Movement by James Timberlake, historians "have demolished Sinclair's picture of rural fanatics and have shown instead that the prohibition crusade was firmly rooted within the native middle class. ${ }^{39}$ Scholars in the 1970s added layers of complexity to the historiography. As K. Austin Kerr explains, "historians were reinterpreting the story of prohibition, portraying it as a response in the mainstream of American reform to real social problems of alcohol use.... Prohibition was part of the social gospel. It was one quest for a social system wherein private behaviors conformed to the social good." ${ }^{40}$ Writers from other fields focused on the prohibition movement around the turn of the twenty-first century. For example, legal historian Richard F. Hamm has explored the interplay between the prohibition movement and bureaucracy in his 1995 work, Shaping the Eighteenth Amendment. According to Hamm, "the experience of the prohibitionists within the American polity from 1880 to 1920 can illuminate much about the nature of the interaction of reform and the structure of government. ${ }^{, 41}$ In her book entitled Pathways to Prohibition, political scientist Ann-Marie Szymanski investigates the electoral

\footnotetext{
${ }^{38}$ Blocker, Retreat from Reform, 4-5.

${ }^{39}$ Blocker, Retreat from Reform, 5.

${ }^{40}$ K. Austin Kerr, Organized for Prohibition: A New History of the Anti-Saloon League (New Haven, CT: Yale University Press, 1985), xii.

${ }^{41}$ Richard F. Hamm, Shaping the Eighteenth Amendment: Temperance Reform, Legal Culture, and the Polity, 1880 1920 (Chapel Hill: University of North Carolina Press, 1995), 2.
} 
approaches utilized by dry groups like the ASL. She finds "that choice of strategy - or how a social movement defines and pursues its goals - is important in determining whether the movement will succeed."

Studies of prohibition in individual states exist. In fact, West Virginia University MA candidate E. Kidd Lockard penned a thesis entitled "The Temperance Movement in West Virginia" in 1937. While the study provides an informative blow-by-blow narrative of the dry effort in the Mountain State from its beginning through repeal, space limitations and a lack of distance from the anti-liquor movement itself do not allow Lockard to place West Virginia's prohibition experience in a meaningful or objective sociopolitical context. Karina Thurston's 2009 MA thesis, entitled "Lenna Lowe Yost, Temperance, and the Ratification of the Women's Suffrage Amendment by West Virginia," also provides solid information on the role of influential women like Lenna Yost in the Mountain State prohibition movement. ${ }^{43}$ However, because Thurston focuses on all aspects of Yost's reform career and not just the anti-liquor crusade, her contribution does not provide a definitive investigation of West Virginia teetotalism. Thurston's thesis is indicative of the level of coverage afforded the prohibition movement in many monographs and scholarly collections about the Mountain State. Prohibition and temperance appear sparingly in the indices of West Virginia-related works, especially in studies covering the socioeconomic and political impacts of industrialization. ${ }^{44}$ Because these scholars

\footnotetext{
${ }^{42}$ Szymanski, Pathways to Prohibition, 5.

${ }^{43}$ Karina Thurston, “Lenna Lowe Yost, Temperance, and the Ratification of the Women's Suffrage Amendment by West Virginia" (MA thesis, West Virginia University, 2009).

${ }^{44}$ Prohibition and Temperance make an appearance in works like Ken Fones-Wolf and Ron Lewis, eds., Transnational West Virginia: Ethnic Communities and Economic Change, 1840-1940 (Morgantown: West Virginia University Press, 2002), Deborah R. Weiner, Coalfield Jews: An Appalachian History (Urbana: University of Illinois Press, 2006), and Fones-Wolf, Glass Towns.
} 
cover other topics or themes, however, prohibition and temperance typically fulfill a marginal rather than central role in the narrative.

"Vending Vice" endeavors to fill this important historiographical gap. Some New Deal scholars realized that in order to make sense of such an enormously complex set of programs, it was necessary to study Roosevelt's initiative on a state-by-state basis. This approach yielded valuable and instructive monographs like Jerry Thomas' 1998 work, An Appalachian New Deal: West Virginia in the Great Depression. "Vending Vice" is an attempt to apply this more local strategy to the overall historiography of prohibition. Michael Lerner and Bruce Stewart recently embraced this approach in their works, Dry Manhattan: Prohibition in New York City and Moonshiners and Prohibitionists: The Battle over Alcohol in Southern Appalachia. "Vending Vice" occupies an instructive space between these two studies. In the years encompassed by this dissertation, West Virginia was never purely southern or northern. It was never completely agrarian or industrial. While each party enjoyed extended periods of success, the Mountain State was never exclusively Democratic or Republican. Consequently, the uniquely complex prohibition experience in West Virginia provides insights that extend beyond the borders of the Mountain State. "Vending Vice" serves as a localized point of departure for other liquor proscription efforts in the industrial North, the rural South, and around the United States. The battle over state prohibition in the Mountain State is a West Virginian and American story. The changing fate of state liquor proscription in this corner of the Republic reflects the changing lives, experiences, fears, expectations, and priorities of not just West Virginians, but of all industrial-era Americans.

\footnotetext{
${ }^{45}$ Michael A. Lerner, Dry Manhattan: Prohibition in New York City (Cambridge, MA: Harvard University Press, 2007); Bruce Stewart, Moonshiners and Prohibitionists: The Battle over Alcohol in Southern Appalachia (Lexington: The University Press of Kentucky, 2011).
} 
Most importantly, though, it is hoped that the analysis provided in this dissertation will shed additional light on the social, political, and economic changes experienced by West Virginia citizens before, during, and after the turn of the twentieth century. In the mid to late nineteenth century, before industrialization had completely changed the face of the Mountain State, West Virginians who did favor prohibition were content to limit liquor consumption in their own areas. This localism was the result of a preindustrial and Southern-oriented aversion to organized state power. According to historian William A. Link, "While the temperance movement strenuously opposed alcoholic culture, it imposed limitations on individual behavior consistent with nineteenth-century conceptions of personal liberty and community responsibility. Temperance advocates accepted and often strongly endorsed the popular tradition against intrusive governance."46 This more locally oriented understanding of government power and social control helps explain why so many of West Virginia's towns, cities, and counties were dry before the turn of the twentieth century, but the entire state never was.

Localized approaches to alcohol control eroded as industrialization caused a fundamental shift in the socioeconomic character of the Mountain State. While both parties believed in development by the 1890 s, they disagreed on how best to encourage the process. West Virginia Democrats tended to favor "a low-wage, low-cost strategy" where the government invested as little as possible. The GOP, on the other hand, subscribed to "the political economy of most of the Northeast, opted for a strategy that relied on high tariffs and the gold standard, and was more accommodating to the wage demands of industrial workers." According to historian Ken FonesWolf, "Republicans won this struggle." ${ }^{47}$ This victory would be made complete in 1894 and

\footnotetext{
${ }^{46}$ William A. Link, The Paradox of Southern Progressivism, 1880-1930 (Chapel Hill: University of North Carolina Press, 1992), 34.

${ }^{47}$ Fones-Wolf, Glass Towns, xxv.
} 
1896 when Republicans swept into power. These elections, according to Fones-Wolf, "signaled a dramatic shift to popular support for the Republican economic program, and their representatives voted for sound currency and high tariffs." 48

As industrialization hit West Virginia, drys joined the Republicans and adopted their own version of a more interventionist approach to liquor proscription. As Link argues, "By the late 1890s . . prohibitionists had concluded that individual temperance efforts were not sufficiently compulsive; that the problem of alcohol was complex, and responsibility for it pervaded the social and political system; and that the solution lay in restricting individual freedom through governmental coercion."49 Mountain State teetotalers became more willing to use state and, eventually, federal power to slay the "Demon Rum." This change in philosophy would result in the implementation of state prohibition in 1914 and federal prohibition a few years later. This progressive and interventionist form of social control, of course, failed in West Virginia and the rest of America. However, this failure is not what is important in "Vending Vice." The rise and fall of state prohibition in the Mountain State matters because it helps shed light, in an accessible way, on the fundamental philosophical, social, economic, and political changes that occurred as a result of West Virginia's transformative experience with industrialization.

\footnotetext{
${ }^{48}$ Fones-Wolf, Glass Towns, 69.

${ }^{49}$ Link, The Paradox of Southern Progressivism, 39, 51.
} 
CHAPTER TWO: Stumbling Toward Perfection: The Early Failures of State Prohibition in West

Virginia, 1852-1881

Resolved, That we the members of the Western Virginia

Conference [of the Methodist Episcopal Church], will wage an unceasing warfare against this monster vice, until his sable flag, foul with the blood of the slain, shall be forever trampled in the dust. $^{1}$

Evangelical Protestant sects and local clubs comprised the vanguard of temperance agitation in the western portion of Virginia nearly three decades before the Mountain State founding of national groups like the Prohibition Party and Women's Christian Temperance Union (WCTU) in the early 1880s. ${ }^{2}$ While West Virginia was ahead of the regional curve in its authorization of statewide prohibition in 1912, it was generally in organizational lockstep with the rest of the nation in the early antebellum period. The temperance movement emerged as a legitimate political force by the 1820 s as the Second Great Awakening made its way across the nation and the American industrial revolution took root. ${ }^{3}$ One of the most important temperance groups in the antebellum period was the Sons of Temperance. Founded in New York City in 1842, this social order focused on three goals: "(1) to shield its members from the evils of

\footnotetext{
${ }^{1}$ Minutes of the Western Virginia Conference of the Methodist Episcopal Church for the Years 1848 to 1857 (n.p., n.d.), 208.

${ }^{2}$ The Prohibition Party first ran a presidential candidate in a West Virginia election in 1884. www.uselectionatlas.org (accessed October 2, 2010); the West Virginia wing of the WCTU began in 1883. Barbara J. Howe, "West Virginia Women's Organizations, 1880s-1930 or 'Unsexed Termagants.... Help the World Along,'” West Virginia History 49 (1990): 2. Accessed on www.wvculture.org (October 16, 2009).

${ }^{3}$ Ann-Marie Szymanksi, Pathways to Prohibition: Radicals, Moderates, and Social Movement Outcomes (Durham, NC: Duke University Press, 2003), 26. The author provides an instructive overview of the early temperance movement in chapter 2 .
} 
intemperance; (2) to furnish mutual assistance in case of illness; (3) to elevate them as men." Group bylaws required that every member take a total abstinence pledge. ${ }^{4}$ Szymanski argues that, superficially, "the Sons of Temperance ... could be dismissed as merely 'dry Masons"” because of the group's affection for the typical trappings of secret societies. ${ }^{5}$ However, she maintains that orders like the Sons of Temperance also served important community and even political functions beyond social exclusivity. Szymanski identifies Sons gatherings as "the temperance equivalent of 'free spaces,' or 'environments in which people are able to learn a new self-respect, a deeper and more assertive group identity, public skills, and values of cooperation and civic virtue." Some of the group's local affiliates also involved themselves in local and statewide politics in the 1840s, unlike some of its precursors which refused to engage in public policy. The Ohio and Virginia Divisions attacked local licensing laws in 1846 and $1847 .^{6}$

Monongalia County was home to a local branch of the Sons of Temperance during the antebellum era. ${ }^{7}$ This group kept records from 1851 to 1856 , meeting once a week in Temperance Hall (presumably in Morgantown). The minute book suggests, however, that this particular branch was much more a "free space" than a vibrant political force before the Civil War as members regularly violated bylaws and irregularly paid their dues. ${ }^{8}$ The apparent lack of real agitation on the part of the Morgantown Sons may have been the result of national

\footnotetext{
${ }^{4}$ Deets Pickett, ed., The Cyclopedia of Temperance, Prohibition and Public Morals (New York: Methodist Book Concern, 1917), 351.

${ }^{5}$ Szymanksi, Pathways to Prohibition, 32.

${ }^{6}$ The American Temperance Union did ally with the Sons to push northern prohibition laws; Szymanski, Pathways to Prohibition, 31-33.

${ }^{7}$ For a more detailed discussion of even earlier antebellum temperance groups in West Virginia, see chapter one of E. Kidd Lockard, "The Temperance Movement in West Virginia" (MA thesis, West Virginia University, 1937).

${ }^{8}$ Minute Books of the Society of the Sons of Temperance, 1851-1856, West Virginia and Regional History Collection, West Virginia University, Morgantown, WV - AM Number 487.
} 
temperance trends on the eve of the Civil War. While Sons of Temperance membership peaked in 1851 with over 220,000 members, the group's rolls declined later in the 1850s as support for prohibition waned. The imposition of so-called "Maine Laws," which called for statewide prohibition, proved difficult to sustain, political and judicial leaders seemed less willing to work with and maintain prohibitionist action, and the rebirth of a genuine two-party system in 1856 marginalized prohibition as "a distraction.",

Evangelical Protestants were by far the most aggressive proponents of temperance reform and prohibition in the ante and post-bellum periods. In Western Virginia, the most forceful group of aggressive reformers was the Methodist Episcopal Church (ME). Historian James Timberlake asserts that evangelical Protestants "gradually advanced towards more and more extreme remedies until total abstinence and prohibition finally came to be the accepted goal of temperance reform. By the 1890 s, these two principles were solidly entrenched." ${ }^{, 10}$ In the case of Western/West Virginia Methodists, however, this transition to prohibition was less gradual and occurred nearly forty years before Timberlake's timeline. One temperance publication incidentally printed by the Methodists - even claimed that prohibition was church policy from its founding: "Upon the organization of the Methodist Episcopal Church in America in 1784, the following was made part of the minutes: 'Q. Should our friends be permitted to make spirituous liquors, and sell and drink them in drams? A. By no means." It also maintained that the era in which the church took a stand against liquor "was anything but hostile to the use of intoxicants." ${ }^{11}$ It is important to note that the Methodist Church was by no means a splinter sect

\footnotetext{
${ }^{9}$ Szymanski, Pathways to Prohibition, 32, 34-35.

${ }^{10}$ James H. Timberlake, Prohibition and the Progressive Movement (Cambridge, MA: Harvard University Press, 1963), 10.

${ }^{11}$ Pickett, Cyclopedia of Temperance, 275.
} 
in Mountain State Christendom. Methodists constituted the single largest faith organization in West Virginia, comprising over one-third of the total religious "sittings" in the state in $1870 .{ }^{12}$ This meant, in essence, that Mountain State Methodists had a tremendous amount of social and political power and that a sizable minority of West Virginians would respect the position of their church leadership on the issue of alcohol policy.

This position would be made clear the decade before the state of Virginia was split in two. Members of the ME Church's Western Virginia region convened their annual conference in Morgantown in 1852. At the conference, church leaders formed a temperance committee for the first time and defined their faith's position on the liquor trade. Considering the consumption of alcohol "a great hinderance to the progress of the Gospel, as well as ruinous to all the best interests of society," they urged their fellow Methodists to "use [their] ministerial and personal influence, in any judicious way, for the suppression of the evils of intemperance in our several fields of labor." ${ }^{\prime 3}$ While the ME Church leadership clearly laid out its theoretical position on alcohol, they offered no structured or functional approaches to the destruction of the liquor trade at this point. The 1853 temperance committee, which also considered drinking a major issue, did "not think it expedient, however, to point out any uniform or particular modes of operation; but leave to the individual members of this body to promote the great cause of temperance in their several fields of labor."14

\footnotetext{
${ }^{12}$ West Virginia had an aggregate population of 442,014 in 1870. Of that, 152,865 were identified as "sitting" Methodists. Francis Walker, ed., A Compendium of the $9^{\text {th }}$ Census of the United States, June $1^{\text {st }}, 1870$ (Washington: Government Printing Office, 1872), 8 and 521.

${ }^{13}$ Minutes of the Western Virginia Conference, 147; The Methodist Episcopal Church's first General Conference in 1848 publicly reestablished John Wesley's prohibitionist decree, Ernest H. Cherrington, ed., The Evolution of Prohibition in the United States of America: A Chronological History (Westerville, OH: American Issues Press, 1920), 131.

${ }^{14}$ Minutes of the Western Virginia Conference, 176-77.
} 
ME leaders exhorted their followers to join the fight against the Demon Rum in the early 1850s, but they never progressed beyond righteous rhetoric. It would not take long, however, for the Methodists to begin augmenting their religious rhetoric with more functional legal and political marching orders. Wheeling, which hosted the 1855 conference, became the center of this evolution from high-minded but ultimately unorganized speechmaking to prescribed action. In issuing their statement, the 1855 temperance committee not only set a moral benchmark for their fellow Methodists, they also defined the ultimate measure of success for do-gooders throughout the Mountain State for the next six decades. Committee members reported that "the advocates of Temperance ask for the enactment of a strong prohibitory law [their emphasis] in this state, as the only hope of final success [their emphasis]." ${ }^{\prime \prime}$ At that moment, the Western Virginia Methodist Episcopal Church, part of the largest Christian denomination in Virginia, switched from a temperance to a prohibitionist church. The temperance committee's six members followed this pronouncement with a detailed list of six political and social strategies aimed at supporting the prohibition cause. This "plan of operation" urged religious leaders and laypeople to preach temperance in local churches, identify and recommend temperance political candidates to parishioners, encourage evangelists to preach temperance on the local level, send prohibitionist petitions to lawmakers, build schools and hire only dry teachers, and make sure that local church elders check the progress of these strategies on a quarterly basis. ${ }^{16}$ Two years later, conference attendees escalated the expected role of Methodist preachers in the prohibition fight, requiring them to preach temperance from the pulpit: "Therefore RESOLVED that we as a Conference use all proper efforts for the extirpation of this evil; and that it be the duty of each

\footnotetext{
${ }^{15}$ Minutes of the Western Virginia Conference, 244.

${ }^{16}$ Minutes of the Western Virginia Conference, 244-45.
} 
pastor to preach upon the subject of temperance at least once at every appointment in his charge." $" 17$

While disquieting to some modern Americans, this intersection between political action and faith was well within the realm of legitimacy in the nineteenth century - as it is considered in some religious denominations and movements even today. People of faith were not consciously attempting to pervert American political expectations of church-state separation. Rather, as legal historian Richard Hamm argues, they saw the law, morality, and God as inexorably linked: "Drys thought human law should strive to reproduce God's commands. . . . Therefore, laws that recognized the liquor traffic by regulating it were wicked as well as inadequate. Thus total prohibition became the only legitimate legal response to liquor.” Instructively, Hamm applies this description of what he identifies as "Mosaic" law to the Prohibition Party and WCTU of the 1880s and 1890s. ${ }^{18}$ As the $1855 \mathrm{ME}$ plan of operation demonstrates, however, the prohibitionist conception of "Godly law" existed in Western Virginia twenty-five years before the author identified it as a part of WCTU and Prohibition Party philosophy. In fact, committee members issuing the 1855 proclamation for state prohibition proffered the measure as part of a larger party debate on the liquor license question. Effectively, the ME Church, like its late-nineteenth century descendants, decided that liquor control via licensing was an unacceptably halfway measure and that state prohibition was "the only hope for final success [their emphasis]."19

Fortunately for Mountain State drys, West Virginia’s founders left open an avenue for this final success when drafting the new state constitution in 1863. Constitutional Convention

\footnotetext{
${ }^{17}$ Minutes of the Western Virginia Conference, 328.

${ }^{18}$ Richard F. Hamm, Shaping the Eighteenth Amendment: Temperance Reform, Legal Culture, and the Polity, 18801920 (Chapel Hill: University of North Carolina Press, 1995), 12.

${ }^{19}$ Minutes of the Western Virginia Conference, 244.
} 
delegates in Wheeling decreed that "laws may be passed regulating or prohibiting the sale of intoxicating liquors within the limits of this state. ${ }^{20}$ While this section provided anti-liquor activists with a tangible and codified goal, it also exposed the uncertain reality of state alcohol regulation in the early years of West Virginia. Lawmakers reserved the right to pass regulatory liquor measures because there were none. This lack of a regulatory structure led to a wildly confused scenario in which the governor himself was so concerned that he confronted the issue in his first inaugural address. Governor Arthur Boreman favored a state license system, which would control the liquor trade by issuing sales permits in exchange for a fee. He worried that if such a system was not enacted, "any person, whatever his character, may indulge in the indiscriminate sale of liquor with impunity, and to the great detriment of society." ${ }^{21}$ Anticipating the potentially deleterious social and even moral impacts of an unregulated liquor trade, Boreman wanted the state to take an active role in the management of vice. He did not, however, go so far as to pressure lawmakers for a prohibitory law. The governor's bureaucratic instincts proved prescient. Because the newly organized state initially lacked the authority to grant liquor licenses and federal agents assured liquor sellers that they were allowed to vend their products, he was forced to remit fines levied on distributors selling without a license. ${ }^{22}$ Mountain State politicians wasted little time correcting this confusion. The 1863 legislature took the governor's advice and passed a licensing law. ${ }^{23}$

\footnotetext{
${ }^{20}$ Quoted in Robert M. Bastress, The West Virginia State Constitution: A Reference Guide (Westport, CT: Greenwood Press, 1995), 173. For a description of the debate over this clause, see Lockard, "The Temperance Movement," 9-11.

${ }^{21}$ Journal of the Senate of the State of West Virginia, 1863 (Wheeling, WV: McDermott Printing, 1863), 14.

22 "Executive Document One," Journal of the Senate of the State of West Virginia, 1864 (Wheeling, WV: McDermott Printing, 1864), 6.

${ }^{23}$ Lockard, "The Temperance Movement," 11.
} 
West Virginia drys did not concern themselves with bureaucratic issues during the infancy of the new state. They saw the 1863 constitutional clause as an opportunity to impose their beliefs on the Mountain State, and they wasted very little time attempting to do so. Throughout the 1860s, anti-liquor advocates and their political allies flooded both houses of the legislature with bills and petitions aimed at eradicating the Demon Rum. In the very first session of the state senate in 1863 , legislators considered a prohibition bill, but it did not pass. ${ }^{24}$ Delegates and state senators introduced two separate bills in 1864. House Bill Number Two, entitled "A Bill to Prohibit the Distillation of Grain," would have punished, via a fine, the production of grain liquor. It, too, failed. ${ }^{25}$ Senators debated Senate Bill 20, which prohibited alcohol in the Mountain State and levied fines and jail time for violators. Instructively, the bill decreed that fines collected would be paid into the state school fund. ${ }^{26}$ Reinvesting fines into a school fund was probably designed to take the edge off of a radical proposal like statutory prohibition. After all, a free shool system was one of Governor Boreman's preferred issues. ${ }^{27}$ This political horse trading proved somewhat effective as Bill 20 passed the senate thirteen to six. Unfortunately for enterprising drys, it did not pass the house as delegates postponed action on the legislation and it died on the table. ${ }^{28}$

In spite of these very early failures, Mountain State prohibitionists continued their dry onslaught throughout the rest of the 1860s. In the spirit of the ME Church's 1850s

\footnotetext{
${ }^{24}$ Journal of the Senate, 1863 , bill directory and 297. The bill, considered in the Senate, was eventually tabled as the session drew to a close.

${ }^{25}$ Journal of the House of Delegates of the State of West Virginia, 1864 (Wheeling, WV: McDermott Printing, 1864), bill directory.

${ }^{26}$ Journal of the Senate, 1864 , bill directory.

${ }^{27}$ John G. Morgan, West Virginia Governors, 1863-1980 (Charleston, WV: Charleston Newspapers, 1981), 11.

${ }^{28}$ Journal of the Senate, 1864,76 and 89.
} 
recommendations, everyday West Virginians saturated the legislature with petitions urging their elected representatives to enact a prohibitory law. In 1864, citizens of Preston County sent a petition to the House of Delegates and it was referred to committee. ${ }^{29}$ This instance of activism would prove to be a mere preview of the flood to come in Charleston. Members of the 1866 session of the House of Delegates agreed to the creation of a Special Temperance Committee whose function was to handle the sheer volume of prohibitionist petitions entering the House chamber. $^{30}$ That same year, attendees at the ME Church Conference issued a proclamation requesting the formation of a special committee "to draft a memorial in the next Legislature of West Virginia, asking for the passage of a law prohibiting the manufacture and sale of ardent spirits." Additionally, the resolution called for the printing of enough petitions to provide conference members with two copies and influential delegates and senators with a copy at the beginning of the legislative session. ${ }^{31}$ Many other Mountain State citizens echoed the direct action of their Methodist cousins. The House of Delegates received fourteen separate petitions concerning the chamber's prohibition bill (House Bill Number 10) in 1867. ${ }^{32}$ Public demands for action prompted the legislature to retain its Special Temperance Committee for another year. It did not, however, prompt lawmakers to pass the bill. Legislators amended House Bill 10 to death, and it passed neither the house nor the senate. ${ }^{33}$

\footnotetext{
${ }^{29}$ Journal of the House of Delegates, 1864, 19.

${ }^{30}$ Journal of the House of Delegates of the State of West Virginia, 1866 (Wheeling, WV: Frew Publishing, 1866), 31.

${ }^{31}$ Minutes of the West Virginia Annual Conference of the Methodist Episcopal Church, Held at Morgantown, WV, March 21, 1866 (Wheeling, WV: Ewing and Company Printers, 1866), 17.

32 Journal of the House of Delegates of the State of West Virginia, 1867 (Wheeling, WV: Frew Printing, 1867), 301 and 309-312.

${ }^{33}$ Journal of the House of Delegates, 1867, 35-6 and 223.
} 
Dry politicians offered another, albeit watered-down, anti-liquor bill during the 1870 state senate session. They designed the legislation "to prevent drunkenness and to punish persons for adulterating intoxicating liquors, and to regulate the sale thereof." ${ }^{34}$ As allencompassing as it was vague in intent, legislators scarcely considered the bill. Senators laid Senate Bill 14 on the table and effectively ignored it to death. ${ }^{35}$ This pattern of submission and rejection would persist from the late 1860s well into the next two decades. While political failure became the order of the day in the 1860s, 1870s, and 1880s, the West Virginia prohibition movement was far from moribund. In fact, increasing numbers of Mountain State citizens joined the effort against legal liquor as more and more Protestant denominations declared themselves for prohibition and special interest groups and political parties emerged both on the national and state levels.

What is important to note about this period is that those joining the fight were true believers; they had to be because the movement continued to experience setback after setback. West Virginia Presbyterians and Baptists and members of the newly minted WCTU and Prohibition Party could not jump on the bandwagon because the wagon had a broken axle. Rather, as Prohibition historian David Kyvig describes the national movement, "A new wave of temperance agitation began with the formation of the Prohibition party in 1869 and the Women's Christian Temperance Union in 1873, two organizations which put prohibition at the top of a list of desired social and political reforms." ${ }^{, 36}$ In the Mountain State, this period of activism would

\footnotetext{
${ }^{34}$ Journal of the Senate of the State of West Virginia, 1870 (Wheeling, WV: Frew Printing, 1870), 48; in the interest of space, the author did not include every single early attempt at liquor regulation. For other attempts, see Lockard, "The Temperance Movement," chapter two.

${ }^{35}$ Journal of the Senate, 1870, 55.

${ }^{36}$ David E. Kyvig, Repealing National Prohibition (Chicago: University of Chicago Press, 1979), 6.
} 
comprise a key organizational interregnum between the overeager failures of the mid-1800s dry movement and its eventual success in the early 1900s. Prohibitionists were effective enough to force serious considerations of a constitutional amendment on three separate occasions in the 1880s, but they were not successful. While drys grew their constituency, developed organizational alliances, and refined their economic, moral, and political arguments, they remained too weak to overcome the economic, moral, and political retorts offered by friends and allies of legalized liquor and the prevailing political and philosophical wisdom of the post-Civil War era in which they operated. As Link contends in his work on southern progressivism, "Few features of social policy [during the post-Reconstruction era] were compulsory or coercive; except for grave emergencies, the sanctity of the individual and of personal liberty remained sacrosanct. This was a system of government in which bureaucracy played no role at all.,37 Most preindustrial West Virginia citizens and their elected representatives would have considered statewide prohibition far too "compulsory or coercive" to accept. In short, Mountain State temperance advocates from the end of the Civil War to the beginning of the 1880 s were ready to levy pressure but not yet able to win.

In 1868, members of the Independent Order of Good Templars laid the groundwork for the formation of a Prohibition Party one year later. They issued an organizational proclamation at their annual conference:

Whereas, We are convinced of the absolute necessity of political action in order to the uniform and ultimate success of the temperance reform, and whereas it is evident that neither of the now existing parties will formally adopt our principles, therefore resolved, that we recommend to the temperance people of the country the organization of a new political party whose platform and principles shall contain prohibition of the manufacture,

\footnotetext{
${ }^{37}$ William A. Link, The Paradox of Southern Progressivism, 1880-1930 (Chapel Hill: University of North Carolina Press, 1992), 7.
} 
importation, and sale of intoxicating liquors to be used as a beverage. $^{38}$

The Templars convened an organizational convention for a national group the next year and ran the first Prohibition Party ticket in the 1872 presidential race. ${ }^{39}$ This prohibitionist organization was active in West Virginia in the 1880s. Nineteenth-century temperance advocates credited the party with successfully forcing the submission of a prohibition amendment to the people during the 1887 state legislative session. Additionally, the group published a statewide prohibitionist newspaper - The West Virginia Freeman - out of Parkersburg. ${ }^{40}$ State Prohibition Party presidential candidates ran for the office from 1884 to 1920 and again from 1928 through 1932. In spite of growing anti-liquor sentiment throughout the Mountain State around the turn of the century, Prohibition candidates never captured more than 1.99 percent of the total vote in West Virginia. $^{41}$

This electoral failure, however, obscures the philosophical impact of the Prohibition Party on the national and state anti-liquor movements. In the 1920s, prohibitionist Ernest Cherrington claimed that the group's “clarion call for aggressive political action was largely responsible for breaking down the ancient doctrine that the temperance movement and political activity should be kept separate, which doctrine had been preached . . . for half a century."42 The Prohibition Party, then, dissolved the boundary between dry activism and the ballot box in the

\footnotetext{
${ }^{38}$ Quoted in Cherrington, The Evolution of Prohibition, 165.

${ }^{39}$ Cherrington, The Evolution of Prohibition, 166.

${ }^{40}$ Walter W. Spooner, ed., The Cyclopedia of Temperance and Prohibition: A Reference Book of Facts, Statistics, and General Information on All Phases of the Drink Question, the Temperance Movement, and the Prohibition Agitation (New York: Funk and Wagnalls, 1891), 116.

${ }^{41}$ www.uselectionatlas.org (accessed October 2, 2010).

${ }^{42}$ Quoted in Cherrington, The Evolution of Prohibition, 167.
} 
same way that Mountain State Evangelical Protestants sects had already dissolved the boundary between dry activism and the church pew in the 1850s. Not only did the party redefine the interplay between moral activism and politics, it also set the stage for the twentieth-century dry movement. Cherrington posits that "although it failed to accomplish its original purpose [the Prohibition Party] certainly helped clear the way for the non-partisan political activity which in later years succeeded in securing what the party as such could not secure."43 The West Virginia wing of the party remained part of the larger prohibition movement well into the 1900s. In fact, it allied itself with several other prohibitionist groups in 1912 and helped secure victory in that year's vote on statewide prohibition. ${ }^{44}$

One of the other groups heavily invested in the 1912 amendment campaign was the WCTU. Founded in Cleveland in the fall of 1874, the WCTU was a pro-temperance spin-off as it became "'the sober second thought' of the Woman's Crusade of 1873-74."45 The group was not a one-issue group like the Prohibition Party. In fact, local, state, and national chapters of the WCTU operated close to fifty "departments" addressing various social, moral, religious, and even economic issues by $1917 .{ }^{46}$ Despite the fact that the WCTU was a fledgling organization in the post-Civil War era, women had been a political force even before the founding of the nation.

\footnotetext{
${ }^{43}$ Cherrington, The Evolution of Prohibition, 167.

${ }^{44}$ Szymanski, Pathways to Prohibition, p. 158.

${ }^{45}$ Pickett, Cyclopedia of Temperance, p. 395.

${ }^{46}$ Pickett, Cyclopedia of Temperance, 395-396; the West Virginia WCTU maintained around twenty special-issue departments by the 1880 s. These included temperance literature, juvenile work, Sabbath school, scientific instruction, influencing of the press, prison and jail work, unfermented wine, railroads, legislation and petitions, flower mission, state and county fairs, colored people work, Union Signal and Freeman (prohibition organs), day of prayer, Sabbath observance, soldiers, hygiene, and social purity. Annual Reports of the Women's Christian Temperance Union, West Virginia, 1886-7-8 (Keyser, WV: Mountain Echo Printers, 1888), 31. Barbara Howe provides a short overview of these activities in "West Virginia Women's Organizations."
} 
According to historian Paula Baker, "From the time of the Revolution, women used, and sometimes pioneered, methods for influencing government from outside electoral channels. . . Women fashioned significant public roles by working from the private sphere."47 Organizers founded the West Virginia WCTU in western Maryland in the summer of 1883, yet historian Barbara Howe suggests that Northern Panhandle women may have jumped on the temperance bandwagon a few years before as "the 1877 Wheeling city directory lists the Ladies' Temperance Union, while the Ladies' Temperance Band was cited in the 1880 directory."48 WCTU organization proceeded quickly in the Mountain State. Members convened their first state convention in Parkersburg by 1884 with seven cities already housing local chapters by then. Union adherents provided a preview of their future anti-alcohol agitation at the first meeting when they "marched down Market Street stopping to pray for those engaged in the liquor traffic." 49

While members of the West Virginia WCTU wished to address a plethora of different issues, it was clear from the beginning that temperance reform via prohibition was at the top of their collective list. At its 1886 state convention, the organization spelled out its major concerns in a series of resolutions:

Resolved I. That the Women's Christian Temperance union is founded and builded [sic] on the twin basal rocks of total abstinence for the individual and legal prohibition for the State, and holding as we do, that the traffic in intoxicating liquors is a sin against God and a crime against the State, we denounce all systems

\footnotetext{
47 Paula Baker, "The Domestication of Politics: Women and American Political Society, 1780-1920," The American Historical Review 89 (June 1984): 621.

${ }^{48}$ Howe, "West Virginia Women's Organizations," 2. Accessed on www.wvculture.org (October 16, 2009). The author is not sure these early groups were connected to the WCTU.

${ }^{49}$ Quoted in Howe, “West Virginia Women's Organizations," 2.
} 
of taxation, license, or regulation, as utterly delusive, wrong in principle and ruinous in results.

II. That the Woman's Crusade for the total prohibition and utter banishment of the liquor traffic was inaugurated thirteen years ago, and we now declare to the world in this second decade of the war, that we will lay down our arms for nothing less than State and National Constitutional Prohibition, firmly established and faithfully enforced.

III. That in our own State we declare our immediate, pressing work to be, to secure the submission of a prohibitory amendment to a vote of the people. ${ }^{50}$

The constitutional elimination of the liquor trade was far from the only issue embraced in the group's long list of conference resolutions. Given the fact that prohibition-related causes comprised the first three items on the list, though, it is clear that most West Virginia WCTU members had turned their attention (and pressure) to state house and senate members by the mid 1880s. Historian Ruth Bordin argues that "the WCTU used all the techniques perfected by the modern Political Action Committee, and like present-day pressure groups produced its results with lobbying techniques that were quite independent of delivering the vote." Women focused on temperance, according to Bordin, because "women found temperance the most congenial cause through which to increase their involvement in public life. ... Women used the WCTU as a base for their participation in reformist causes, [and] as a sophisticated avenue for political action."

This clear, aggressive, and uncompromising position on alcohol caught the attention of and created philosophical alliances between the WCTU and the other political and religious elements of the nineteenth-century prohibition movement in the Mountain State. Perhaps acknowledging their disfranchisement, WCTU members stated "that while we are not and cannot

\footnotetext{
${ }^{50}$ Annual Reports of the WCTU, 18.

${ }^{51}$ These "techniques" included the petition; Ruth Bordin, Woman and Temperance: The Quest for Power and Liberty, 1873-1900 (New Brunswick, NJ: Rutgers University Press, 1990), xv and xxiv.
} 
be a political organization, we express our appreciation of those voters who declare their purpose to cast their ballots against the liquor traffic, first, last and all the time, for the protection of the home." This lack of real-world political power did not prevent the group from resolving that prohibitionist women should support the Freeman newspaper, a weekly that would eventually become an organ for the Prohibition Party. ${ }^{52}$ Additionally, ties bound through common moral cause existed between anti-liquor women and Mountain State evangelical Protestants early on. The 1874 ME Conference issued a proclamation lauding the efforts of the "Women's Crusade against Whiskey." ${ }^{, 53}$ West Virginia Methodists would even provide functional assistance to female prohibitionists a decade later. When Morgantown women organized the University City's WCTU chapter in 1884 and 1885, they met in the local Methodist Episcopal Church. ${ }^{54}$

West Virginia's ME chapels were far from the only Protestant churches echoing with the voices of prohibitionist agitation before the turn of the century. While eighteen separate Protestant denominations had adopted anti-liquor positions on the national level by 1917, many of the other most popular evangelical denominations in the Mountain State had turned against the Demon Rum by the 1880 s. $^{55}$ The Presbyterian Church joined the dry army almost as quickly as its ME cousins. At its 1864 General Assembly, the Presbyterians ordered "that the rule of total abstinence be enforced 'as rigorously as the honor of religion and the cause of temperance

\footnotetext{
${ }^{52}$ Annual Reports of the WCTU, 19; the West Virginia Freeman was initially an independent temperance weekly. While it is unclear when it became an organ for the Prohibition Party, it did reprint the party's slate in its 1888 issues.

${ }^{53}$ Minutes of the West Virginia Annual Conference of the Methodist Episcopal Church, Held at Fairmont, WV, March 11, 1874 (Wheeling, WV: Daily Intelligencer Steam Book and Job Press, 1874), 18.

${ }^{54}$ Women's Christian Temperance Union, Morgantown - Minutes, 1897-1934, West Virginia and Regional History Collection, West Virginia University, Morgantown, WV - AM Number 2998.

${ }^{55}$ Pickett, Cyclopedia of Temperance, 85.
} 
demands. ${ }^{, 56}$ West Virginia Baptists were not quite as alacritous as the Presbyterians or Methodists in their denunciation of the liquor trade. ${ }^{57}$ When the Baptist Church convened its first few annual meetings in the 1860 s, they neither made mention of temperance or prohibition nor did they manage specific committees addressing the issue. ${ }^{58}$ By the end of the next decade, however, Mountain State Baptists were firmly seated on the water wagon. In fact, their temperance committee's 1879 report closely mirrors the resolutions advanced by other churches and prohibitionist organizations:

We therefore recommend $1^{\text {st }}$. That our ministers be requested and urged to be untiring and ceaseless in their efforts to educate the people to a right conception of the alarming evils of intemperance.

$2^{\text {nd }}$. That great care be taken in the training of the young so that a healthy public sentiment on the subject of Temperance may be secured.

$3^{\text {rd }}$. That we as Christians and citizens work personaly (sic) and faithfully to secure total abstinence from strong drink on the part of all, and that our influence be exerted in our homes, in society and at the poles (sic) against intemperance.

$4^{\text {th }}$. That we deplore and denounce the practice prevailing to some extent in our State, of the illicit distilling of strong drink; and that we support with our votes and influence such laws and administrations as prohibits the sale of intoxicating drink. ${ }^{59}$

Additionally, Baptist leaders suggested a measure of interfaith and intergroup cooperation by the 1880s. Similar to their WCTU sisters, the temperance committee complimented and urged

\footnotetext{
${ }^{56}$ Cherrington, Evolution of Prohibition, 157. It is unclear exactly when West Virginia Presbyterians first advocated a dry position as the first meeting of the church's West Virginia Synod was not convened until 1904.

${ }^{57}$ The Broad Run Baptist Association did agitate for a prohibitory law in 1852; Lockard, "The Temperance Movement," 6.

${ }^{58}$ Baptist Church records are scattered. The first convention convened in 1865 and no mention was made of temperance at the 1865,66 , or 68 assemblies.

${ }^{59}$ Minutes of the $15^{\text {th }}$ Annual Session of the Baptist General Association of West Virginia (Parkersburg, WV: Elletson Book and Job Printer, 1879), 13.
} 
support for the Parkersburg Freeman in its 1881 report to the conference. ${ }^{60}$ The southern branch of the ME Church joined their estranged northern siblings in attacking legal alcohol a year before the establishment of the West Virginia WCTU. According to twentieth-century prohibitionist Ernest Cherrington, "The Methodist Episcopal Church, South [made] sweeping declarations against the liquor traffic and [stood] unreservedly for Prohibition" in $1882 .{ }^{61}$

It is important to note that, in spite of the burgeoning and relatively diverse collection of dry constituencies at work in 1880s West Virginia, the anti-liquor movement remained a minority cause before the turn of the twentieth century. With the possible exception of Prohibition Party members, one's religious, political, or social affiliation did not guarantee that he or she was a dry. West Virginia Methodists, Baptists, Presbyterians, and middle or upperclass women were not necessarily teetotalers simply because they were Methodists, Baptists, Presbyterians, or well-off women. While religious and social leaders may have urged their constituencies to swear off liquor, Mountain State citizens always reserved the right to ignore the advice. This truth only partially accounts for the fact that prohibition was far from an overwhelmingly popular cause in the late 1800s. Another factor is that, in spite of the fact that the West Virginia dry movement crystallized early relative to other parts of the nation, Gilded Age prohibition agitation operated before its time. When Mountaineer drys advanced their agenda in the 1880s, they were trying to sell a progressive-era reform to a citizenry that mostly remained ensnared in a pre-progressive mentality. In effect, these activists were protoprogressives. The sad truth that many drys learned only after their sound defeat in 1888 was that most West Virginians were either unwilling to support a drastic change like statewide prohibition

\footnotetext{
${ }^{60}$ Minutes of the Seventeenth Annual Session of the Baptist General Association of West Virginia (Parkersburg, WV: Elletson Book and Job Printer, 1881), 18.

${ }^{61}$ Cherrington, Evolution of Prohibition, 214.
} 
or they just did not care. As evidenced by the sheer number of dry counties in the 1880s, many Mountain State citizens accepted the idea of localized liquor proscription. However, they were not yet philosophically ready to authorize the same prohibitionist legislation on the state level. As Link asserts, "Post-Reconstruction southerners . . . despised concentrated power, most of all the governmental coercion and intervention that they believed anticipated military dictatorship and a negation of personal liberty." This pre-progressive attitude insured that "the implementation of alcohol policy ... operated under limitations that public opinion and local custom imposed." ${ }^{62}$

Mountain State prohibitionists created quite a political racket in the 1880 s, but most of the citizens around the state and many of the delegates and senators in Charleston simply ignored their cries. In essence, they were unable to win the grand political prize - the great moderate middle. To many drys, eliminating the legal trade in intoxicating beverages was a crusade. As we know already, beginning with the Methodists in the 1850s and continuing with the Prohibition Party and WCTU in the 1880s and 90s, Gilded Age teetotalers believed in a mosaic construction of the law where God's expectations could and must be applied to real-world policy. ${ }^{63}$ Total prohibition, then, was the closest thing to recreating heaven in West Virginia. However, prohibitionists, especially evangelicals, did not operate solely from a religious motivation. Many Protestants also contextualized and even argued the prohibition issue from a social and economic standpoint. Timberlake presents this two-headed approach in his introductory discussion of the progressive-era anti-liquor movement. He argues that "intemperance, therefore, was a vice to be combated not out of a concern for otherworldly

\footnotetext{
${ }^{62}$ Link, The Paradox of Southern Progressivism, 3, 7.

${ }^{63}$ Hamm, Shaping the Eighteenth Amendment, 12.
} 
salvation alone, but out of a this-worldly desire for freedom, prosperity, and happiness." To the evangelicals who supported the repeal of legal liquor, then, drinking held Americans back. According to Timberlake, "Economically and socially, intemperance was stigmatized by the evangelical churches because it struck at the well-being of the individual and prevented him from achieving success." 64

While the author was speaking of progressive-era evangelical prohibitionists on the national level, he could have easily been addressing the dry movement in the Mountain State before the dawning of the Progressive Era. Prohibitionist political, social, and religious groups launched attacks based on what they believed to be morally and economically correct philosophical arguments throughout the 1880s. Unfortunately for the drys, the majority of citizens, politicians, and opinion makers in pre-progressive West Virginia did and could not abide philosophically moralistic debates about right and wrong. Politicians and civic leaders had budgets to balance and reelections to win. While some delegates, state senators, mayors, and judges allied themselves with the movement and even actively fought for anti-liquor legislation, many political leaders either did everything they could to avoid the issue or actively opposed state prohibition. Many politicians politically sidestepped a state prohibition amendment because taking a stand on such a controversial and seemingly harsh measure could alienate portions of their respective constituencies. While it may have been safe for civic leaders from smaller, largely agrarian, and religiously monolithic locales like Clay, Hancock, and Nicholas counties to join dry activists out on their prohibitionist limb, other politicians faced significantly more complex socioeconomic constituencies and circumstances. ${ }^{65}$

\footnotetext{
${ }^{64}$ Timberlake, Prohibition and the Progressive Movement, 9.

${ }^{65}$ Clay, Hancock, and Nicholas were the only three counties to vote for state prohibition during the 1888 referendum; Morgantown Post-Chronicle, November 6, 1912.
} 
The Republican and Democratic parties were equally reticent to assume an official position. As historian Sean Cashman observes in his description of the national political scene around the turn of the twentieth century, "The two parties were like competing stagecoaches splashing each other with mud but going by the same road to the same place. The Republicans and Democrats were agencies to capture power. . . They did not interpret their task to include making controversial issues accessible." 66 In spite of their active and reasonably wellcoordinated efforts at political and public pressure, Mountain State drys also failed to control the public discourse in the 1880s. Evangelicals and their political and social allies may have organized conferences, issued proclamations, held rallies, joined marches, and even published a weekly prohibitionist organ, but they never controlled enough of the popular media to win. As one prohibitionist alleged at the beginning of the 1890s, "The Wheeling Intelligencer (Rep.) and Register (Dem.), the chief dailies of the State, fought the Amendment unscrupulously, and comparatively few of the country weeklies favored it. The newspapers generally were corrupted by saloon money." ${ }^{67}$ While the allegation of corruption is, by nature, difficult to prove, there is little doubt that many elements of the West Virginia press either did not favor prohibition or stayed out of the fray, especially once politicians submitted the amendment to the people during their 1887 session. They took these positions not necessarily because they were bought by secret saloon agents but because they believed -like many politicians - that acceding to such a largescale change could precipitate fundamentally negative changes to the social, moral, and economic reality of their respective locales and of the entire state. Therefore, these opinion makers, along with their political and liquor industry allies, countered the moralistically-based

\footnotetext{
${ }^{66}$ Sean Dennis Cashman, Prohibition: The Lie of the Land (New York: The Free Press, 1981), 6.

${ }^{67}$ Spooner, The Cyclopedia of Temperance and Prohibition, 116.
} 
contentions of the drys with their own, more well-grounded moral and economic arguments. It would be these real-world talking points that would, at least in the pre-progressive 1880s, prevail.

Dry agitators set the bar high in the 1880s. Eschewing the smoother road to state prohibition via a law passed by a simple majority in both houses (statutory prohibition), West Virginia teetotalers demanded constitutional prohibition. Perhaps not surprisingly, this statelevel call would presage the chosen strategy of the national prohibition movement during the progressive era. According to Kyvig, “An amendment to the [federal] Constitution obviously appealed to temperance reformers more than a federal statute banning liquor. . . Drys feared that an ordinary law would be in constant danger of being overturned." A Constitutional amendment would be much less subject to the changing whims of voters and their elected representatives. ${ }^{68}$ Of course, the process of obtaining a prohibitory amendment to the West Virginia Constitution was multi-layered and quite difficult. Drys not only needed to secure two-thirds votes in each chamber of the legislature, they also had to convince the majority of their neighbors to support prohibition in a subsequent statewide referendum. While the dry element's desire for a stronger, constitutional law is understandable, given the intensity of their beliefs, it probably prevented the passage of prohibition in the 1880s.

Mountain State Baptist leaders seemed more than willing to trade convenience and sure victory for permanence in 1881. The Temperance Committee at the Baptist annual meeting issued as its first resolution of the session "That we heartily endorse the present movement to secure an amendment to the Constitution of West Virginia prohibiting forever the manufacture and sale of intoxicating liquors within the limits of this state." Additionally, the committee

\footnotetext{
${ }^{68}$ Kyvig, Repealing National Prohibition, 7.
} 
promised Baptist support and encouraged "our people ... to aid the work by signing the petitions and securing signers for them, by holding meetings for arousing interest in prohibition and for an effective campaign when the amendment is submitted." It is important to note that Baptist leaders convened their annual session months after the 1881 legislature had voted down the amendment earlier in the winter. ${ }^{69}$ In spite of their timing, the combined strategies of popular pressure and mass meetings enunciated in these resolutions were and would continue to comprise the backbone of the anti-liquor movement, Baptist or not, both during and after the 1881 campaign. Perhaps not surprisingly, the Methodist Episcopal leadership, who attended their session in the fall as well, echoed the sentiments of the West Virginia Baptist Association. They also pledged cooperation with the state prohibition campaign. ${ }^{70}$

The Fairmont Index reported in a story reprinted in the Republican weekly Preston County Journal that petitions demanding constitutional prohibition were well received in Marion County. ${ }^{71}$ Legislative records indicate that the dry petition campaign was successful in more than just the northern coalfields. The 1881 state senate index listed sixteen separate petitions favoring a prohibitory amendment. ${ }^{72}$ On January 31 , dry petitioners and other supporters got their wish as the Committee of the Judiciary reported Senate Joint Resolution Number Nine back to the Senate. The Resolution's details were as follows:

that section 46 of article 6 of the Constitution, as it now is, be stricken out, and the following inserted in lieu thereof: The manufacture and sale of intoxicating liquors shall be forever prohibited, except for medicinal, scientific, and mechanical

\footnotetext{
${ }^{69}$ Minutes of the Seventeenth Annual Session, 1881, 18.

${ }^{70}$ Minutes of the West Virginia Conference of the Methodist Episcopal Church held at Moundsville, WV, October $5^{\text {th }}$ $10^{\text {th }}, 1881$ (Akron, OH: Beacon Publishing, 1881), 41-42.

${ }^{71}$ Preston County Journal, January 27, 1881.

${ }^{72}$ West Virginia Journal and Bills of the Senate, 1881 (Wheeling, WV: Public Printers, 1881), v.
} 
purposes; and the legislature shall enforce this section by appropriate legislation. $^{73}$

State newspapers wasted little time handicapping the bill's chances; opinions varied on whether or not Joint Resolution Nine would make it to the referendum ballot. The Fairmont Index reported that "it is the opinion of many ... that under the circumstances the chances would be against the success of the proposition."74 Wheeling Republicans who picked up their February 7 editions of the Daily Intelligencer probably came away just as confused as the journalists attempting to divine the resolution's ultimate fate. The editorial board seemed confident that the legislature would decide to approve the amendment and pass it on to the citizens for a vote. They were even convinced that a prohibitory amendment would have a fifty-fifty chance, if not better, of being approved in a referendum. However, another article detailing the uncommitted positions of prominent state senators was less sure. While it seemed to the reporter that the amendment would probably survive the House of Delegates, "[T]he passage of the amendment in its present shape by the Senate looks rather dubious.",75

In spite of its uncertain future, or perhaps precisely because of it, dry elements throughout the state threw their full weight behind Senate Joint Resolution Nine throughout the 1881 legislative session. Editors at the Intelligencer reported that 19,000 West Virginians from all over the state had signed petitions by early February "and also all political parties, as well as every variety of religious creed and faith, [were] praying the two houses to submit the amendment." ${ }^{, 76}$ At least one West Virginia newspaper commented on the unprecedented nature

\footnotetext{
${ }^{73}$ Journal and Bills, 1881, xv and 68-69.

${ }^{74}$ Quoted in Preston County Journal, January 27, 1881.

${ }^{75}$ Wheeling Daily Intelligencer, February 7, 1881.

${ }^{76}$ Wheeling Daily Intelligencer, February 7, 1881.
} 
of the volume of petitions flooding the state house. The Point Pleasant Register maintained that "we have never known so many petitions to the Legislature of this State upon any subject, as have been presented this session in behalf of the temperance cause."77 Of course, Mountain State teetotalers, many of whom had been waiting for an end to the liquor trade since before the rending of Virginia, hardly limited their efforts to prayer circles and petition signings. Only a few days after the judiciary committee reported the prohibition resolution to the Senate, friends of the legislation held a temperance meeting at the Fourth Street ME Church in Wheeling. This meeting was undoubtedly only one of many such rallies occurring throughout West Virginia while the legislature was in session. As one newspaper reported in the middle of February, "The temperance boom increases. Nightly meeting are held at different points in [Wheeling]."78 However, while it was only one of many, the Fourth Street rally provides valuable insight into the worldview that informed the 1880 s anti-liquor movement.

Judge Ferguson, a House of Delegates member from Kanawha County, was the featured speaker at the Fourth Street Church. His speech, which was apparently well received as the gender-mixed audience interrupted with applause regularly, struck a stark and uncompromising tone on the question of statewide prohibition. The judge argued that "I have lived long enough to know that the one remedy against the great evil is the total prohibition of the traffic." Ferguson was quick to dismiss the established system of granting licenses to sell alcohol on the local level. According to the delegate, the license system had to be considered in the most simplistic of terms: "[I]t is either right or wrong, and if wrong it is not right to license that wrong, and the government that does it perpetrates an outrage on its people... . The logical

\footnotetext{
${ }^{77}$ Point Pleasant Register, February 23, 1881.

${ }^{78}$ Quoted in Preston County Journal, February 17, 1881.
} 
conclusion therefore, is: that the traffic being wrong it should not be legalized." Ferguson also dismissed the loss of local and state revenue once state prohibition went into effect. He argued that the cost of felony cases comprised almost twice as much as the total state revenue produced from liquor licenses. The judge then pointed to his experience as a lawyer and claimed that the vast majority of the men he defended in murder trials committed the crime under the influence of alcohol. Ferguson framed the campaign to submit the amendment as "a question of the people people of both parties." Continuing his call for bipartisanship on the prohibition question, he warned state politicians that "if they allow party feeling to enter into this matter that the politics of this State will get such a shaking up as they never before experienced." At the end of his speech, the judge exhorted the attendees to remain vigilant and to continue signing and transmitting prohibitionist petitions: "The prohibitory amendment was passed in Kansas by the people speaking for it, working for it, and praying for it. That we must do.",79

The Fourth Street ME Church hosted another mass meeting about a week later on the night of February 10, 1881. This time, teetotalers heard from Dr. George Hayes of Washington, Pennsylvania. While the Wheeling Register did not reprint Hayes' speech in its entirety, it did provide a brief summary and recount one of the Pennsylvania speaker's more vivid and frankly spurious metaphors. In front of an audience that included citizens of both sexes and members of the legislature, Hayes advocated a prohibition amendment by telling the story of annoying pig sties in a neighboring town. He recounted that the local authorities determined that the animal pens were a nuisance, and law enforcement officials removed them. To Hayes, there was little difference between a pig sty and a saloon: "How much more a nuisance then was a saloon? For

\footnotetext{
${ }^{79}$ Quoted in Wheeling Daily Intelligencer, February 3, 1881.
} 
he would rather have a pig sty next door to him than a saloon." ${ }^{80}$ Of course, liquor elements and their wet allies did not simply stand by and allow West Virginia drys to control public and political opinion. While wets were certainly not as vocal or even as publicly organized as their dry opponents, they offered up their own roster of writers and speakers to influence opinion, especially in the halls of government. At one point during the legislative session, the liquor interests presented to lawmakers copies of a speech from Christian temperance advocate and university Chancellor Dr. Crosby of New York in which he opposed the prohibition of wine and beer and doubted the efficacy of total prohibition "as a means to eradicate drunkenness."

For the most part, the editorial board of the state's most important daily - the Wheeling Intelligencer - attempted to stay out of the fray in spite of its location in West Virginia's brewing capital. Editors at the Republican Intelligencer chose to adopt the middle-ground position of favoring submission of an amendment to the people. While not necessarily advocating a position, the Intelligencer did acknowledge the growing dry sentiment throughout the Mountain State: " $[\mathrm{H}]$ ere in our own state there are about one-half of the counties that do not grant a license to sell liquors as beverages, and it is not to be disguised that the growing and aggressive public sentiment of the State is radically in the temperance direction." This public opinion, according to the Intelligencer, was being pushed by the flood of statistics suggesting that liquor was the cause of many social ills. Because of this overwhelming sentiment, editors at the Republican daily stated that "no matter what their own private sentiments may be ... it is their duty as legislators to take cognizance of the wishes of nineteen thousand respectable people [petitioners]

\footnotetext{
${ }^{80}$ Wheeling Register, February 11, 1881.

${ }^{81}$ Preston County Journal, February 17, 1881. He is identified as Chancellor of the University of New York in the account in the Wheeling Register, February 18, 1881.
} 
in the state" and submit the amendment. ${ }^{82}$ Journalists at the Intelligencer probably underestimated the number of teetotaler counties at the beginning of 1881 . They did not, however, underestimate the rise of dry opinion in West Virginia. One prohibitionist paper reported in July of 1881 that there existed "thirty Prohibition counties in April, and forty-one in June." 83

While the Intelligencer tried its best to retreat from the political battle, its editorial pages and especially those of the Democratic Wheeling Register became the center of a rhetorical battle between wet and dry forces in early and mid February. Realizing that the prohibition issue was simply too politically sensitive for either party to support or oppose openly, some interested readers attempted to strike a conciliatory tone - simply arguing that politics should be avoided, the resolution should be approved, and the amendment should be sent to the people. ${ }^{84}$ However, many citizens tried on the philosophical vestments of their respective camps and shouted in favor of or against state prohibition. One prohibitionist reader, writing under the pseudonym "J.", adopted oddly progressive-era language in dismissing the right of liquor distillers and sellers to their investments. Further, he argued that "it is a principal as old as government itself that the rights and interests of the individual [his emphasis] must give way to the common weal." "J." then asked the men and women of the state to think of their homes and the families affected by the alcohol trade and "in the name of humanity- in the name of God let them give the people the poor privilege of saying whether they will have this traffic or not." ${ }^{\prime 85}$

\footnotetext{
${ }^{82}$ Wheeling Daily Intelligencer, February 7, 1881.

${ }^{83}$ West Virginia Freeman, July 6, 1881. The figure of 41 was actually 39 as two of the counties included in the dry ledger (Greenbrier and Monroe) allowed liquor at their resorts. These counties tended to be interior or rural. 
Anti-amendment reader "Justice" offered his opinion on the resolution in the Wheeling Register. Arguing that the Intelligencer was effectively in league with and encouraging Mountain State prohibitionists, he maintained that "the cry of fanaticism and old fogyism will be used against us as a very effective means to retard our progress." He then presented figures to underscore the economic importance of license revenue to the city and the farmers of the state derived from the liquor trade in Wheeling. After presenting these numbers, he wondered aloud: "How much do our ministers, children, churches, and others closely connected with every hysterical movement contribute to replenish our empty treasuries?" "Justice" even implied that some of the 19,000 petition signatures may have been forged: "Let the nineteen thousand children, women, and nom de plumes [his emphasis], who pay no taxes, some of whom do not enjoy even the privilege of living, pay to the present legislature thirty thousand dollars [in lost license revenue] to defray the actual expenses of an experimental election of such tenor." ${ }^{\prime 86}$ Another interested citizen by the name of "Plain Talk" supported submission of the amendment but was concerned about how some temperance mass meetings would be perceived by West Virginia Christians. Noting that such rallies had been held on Sunday evenings, the writer cautioned "that it is exceedingly repugnant to the feelings of many serious Christians to attend a temperance meeting ... to find that it assumes more the character of a theatrical performance than that of a sober reformatory movement. ${ }^{, 87}$

This small sampling of opinion indicates the intensity of feeling on both sides of the prohibition question, at least among those who had an opinion on the matter. State senators attempted to navigate these philosophically and morally charged waters as they convened the

\footnotetext{
${ }^{86}$ Wheeling Register, February 16, 1881.

${ }^{87}$ Wheeling Register, February, 18, 1881.
} 
1881 legislative session. While many politicians trod around the issue as carefully as possible, there is some evidence to suggest that the will to let voters decide on the resolution existed, especially at the beginning of the session. Only a few days after the judiciary committee referred Joint Resolution Nine to the Senate on February 4, representatives, led by Senator Faulkner (a staunch opponent of the resolution), voted eighteen to five in the affirmative to take up the resolution out of order, making the legislation the special order of the afternoon a week later. ${ }^{88}$ When February 11 arrived, throngs of interested citizens descended upon the capital, eagerly anticipating discourse on the prohibition resolution. However, Senator Faulkner was able to lay Resolution Nine on the table until the sixteenth. The interested parties "left as with one mind, disgusted at the failure of the Senate to consider the amendment." 89

Citizens indeed got their chance to watch the political sparks fly on February 16. Interested parties, including many women and key temperance advocates, flooded the senate, excited by the prospect of the resolution's consideration during the afternoon session. ${ }^{90}$ Over the next two days, the state senate echoed with a vexing mix of rhetoric, debate, accusations, rebuttals, and procedural sleights of hand far too complicated to retell fully here. Ultimately, opponents of the bill, led by Berkeley County Senator Faulkner and Ohio County Senator Woods, secured enough anti-prohibition support to outmaneuver the bill's proponents, led by Jackson County Senator Brown. ${ }^{91}$

\footnotetext{
${ }^{88}$ Wheeling Daily Intelligencer, February 5, 1881; Journal and Bills of the West Virginia Senate, 1881 (Wheeling, WV: Public Printing, 1881), 87-88.

${ }^{89}$ Wheeling Daily Intelligencer, February 12, 1881.

${ }^{90}$ Wheeling Daily Intelligencer, February 17, 1881.

${ }^{91}$ Wheeling Daily Intelligencer, February 17, 1881, and, February 18, 1881.
} 
When the bill came up for consideration on the sixteenth, senators scrambled to complicate the resolution's procedural path. Judge Brown asked the Senate for a one-week postponement, Faulkner requested immediate action, and Woods demanded that the resolution be indefinitely postponed. ${ }^{92}$ Initially, the strategy adopted by opponents of the bill may seem counterintuitive as Senator Faulkner, who had asked for a delay only a few days earlier, was now requesting immediate consideration of the resolution. This shift was probably the result of Faulkner's and Woods' confidence that they now possessed the necessary votes to force immediate consideration then indefinite postponement of Joint Resolution Nine, which would effectively kill the legislation for the 1881 session. Senator Brown, perhaps now concerned about his thinning support base, claimed that the bill needed to be postponed for a week because of other, pressing legislation on the docket. ${ }^{93}$ The Jackson County member also warned that indefinite postponement of the measure would only delay the issue until the next session and that West Virginia politicians could not avoid deciding on state prohibition forever. ${ }^{94}$ According to Brown, "The people have petitioned for the privilege of voting on this question and we have no right to refuse them. . . Let us not shirk our duty in this matter." ${ }^{.95}$ Ultimately, Brown's appeals fell on deaf ears. On the seventeenth, senators voted fifteen to nine to postpone indefinitely consideration of the resolution, effectively snuffing out state prohibition for at least one year. ${ }^{96}$

While a brief overview of the bill's procedural fate is necessary, arguments advanced by proponents and opponents of state prohibition are just as important. In the course of the 1881

\footnotetext{
${ }^{92}$ Wheeling Daily Intelligencer, February 17, 1881; Wheeling Register, February 17, 1881.

${ }^{93}$ Wheeling Daily Intelligencer, February 17, 1881.

${ }^{94}$ Wheeling Daily Intelligencer, February 17, 1881; Wheeling Register, February 17, 1881.

${ }^{95}$ Wheeling Daily Intelligencer, February 17, 1881.

${ }^{96}$ Wheeling Register, February 18, 1881; Journal and Bills, 1881, 141-142.
} 
senatorial debate and the many debates to come, many of the shreds of evidence and rhetorical strategies that would be marshaled and implemented over the next 130 years emerged. Additionally, the regional and economic realities considered by the citizens' representatives when deciding whether or not to support prohibitionist or authorization legislation begin to come to light. It is appropriate that an anti-prohibitionist senator from the industrial and brewing capital of West Virginia butted heads with a prohibitionist senator from one of the Mountain State's most rural counties during the 1881 session. As one reader opined just a few days before the commencement of hostilities, "No political party heretofore in this state has taken a position on the temperance question. It would be dangerous for a party to do so." Therefore, according to the reader, this lack of a party prohibition plank "allowed the people belonging to either party to be free to be governed by individual opinion. ${ }^{97}$ While some party clarity would eventually develop on the prohibition question, most politicians - and citizens for that matter - would consider the economic, moral, and political conditions of themselves, their neighbors, and their constituents when deciding whether or not they favored the limitation or liberalization of "vice."

Ohio County Senator Woods, when defending his motion for indefinite postponement, argued that his strategy would reveal the prevailing opinion of the prohibition resolution and gauge sentiment in the chamber. ${ }^{98}$ While his contention was only partially true, as he most likely pushed for postponement because he knew he had the votes to do so, Woods was not completely disingenuous. State senators did effectively avoid an up or down vote on whether or not to pass the resolution on to the House of Delegates and then perhaps on to the citizenry. However,

\footnotetext{
${ }^{97}$ Wheeling Register, February 11, 1881.

${ }^{98}$ Wheeling Register, February 18, 1881.
} 
senators still debated the merits of state prohibition - albeit quite cautiously - and cast the votes, even if procedural, which determined the ultimate fate of antiliquor legislation in 1881.

Proponents of the measure borrowed heavily from dry talking points as they argued against indefinite postponement and for a statewide prohibition referendum. In addition to the usual moral and economic evidence presented by antiliquor activists, senators like Judge Brown cast themselves as the protectors of the peoples' political will. In their eyes, Mountain State legislators were obligated to pass on the resolution because the stream of dry petitions circulating the Capital chambers had indicated the citizenry's wishes. Opponents of Joint Resolution Nine, on the other hand, were forced to navigate a treacherous political path. While they had to defend the interests of their constituencies by marshalling evidence suggesting that a state prohibition law was impractical, would damage economies, and would violate property and political rights, senators like Faulkner and Woods had to avoid looking like they were ignoring the will of the people. Additionally, these senators needed to strike a balance between supporting temperance and opposing this version of temperance legislation.

On the sixteenth, Senator Dennis from Greenbrier County, who favored postponing the resolution indefinitely, responded to Brown's admonition that the senators not shirk their legislative duties. Careful to maintain his image as a man in favor of temperance, Dennis reassured the audience that "he freely confessed that he was a temperance man, and regretted the evils of drunkenness as much as any Senator on the floor, but he didn't propose to shirk his duty."99 While Brown rushed to clarify his statement and another pro-resolution senator expressed his objections to indefinite postponement, Senator Faulkner shortly seized the initiative and outlined the problems with the bill and his reasons for supporting its postponement.

\footnotetext{
${ }^{99}$ Wheeling Daily Intelligencer, February 17, 1881. Dennis is identified in the February 18 edition of the Wheeling Daily Intelligencer as the senator from Greenbrier County.
} 
Wondering why the people needed to be burdened with a vote on state-level prohibition, Faulkner pointed out that half of the petitioners, many of them women, signed in favor of a prohibitive measure "because they objected to the saloons." They were not aware, according to Berkeley County's senator, that the State Constitution already allowed for the limitation of the liquor trade and the regulation of public drinking establishments. ${ }^{100}$

Faulkner continued his speech by restating the majority of the wet coalition's platform. Like Senator Dennis, Faulkner reassured the body that he and his anti-resolution allies were not in favor of intemperance. He maintained that, contrary to popular belief, the anti-resolution senators were not anti-temperance; they simply disagreed that complete prohibition would create a temperate citizenry. According to the Eastern Panhandle politician, "You cannot legislate men into temperate and moral habits. It cannot be done by coercion, but must be the result of moral suasion." Faulkner then commented on the problems inherent with administering and imposing prohibition on the state level by pointing at Maine. He argued that their state prohibition law did little to limit the availability of liquor or save the family. The senator also wondered aloud how the state's dry citizens proposed to refill the state's coffers once prohibition eliminated over $\$ 35,000$ in revenue. According to Faulkner, "If this [revenue] were removed, it would necessitate, to make up the deficit, an additional tax of 3 cents on every $\$ 100$ valuation of property." Berkeley County's senator also detailed the recourse that West Virginia's liquor interests would retain as property owners if state prohibition became the law of the land. Faulkner argued that Mountain State wets had a constitutional right to their private property and asked, "Could not the owners of large distilleries and breweries recover [their losses] from the

${ }^{100}$ Wheeling Daily Intelligencer, February 17, 1881. 
State?" ${ }^{\prime 101}$ Continuing his economic argument, Senator Faulkner concluded his speech by reminding the body's members that his constituent county was home to a distillery producing liquor sold not in West Virginia, but to outside markets in Baltimore and Philadelphia. He claimed that state prohibition would force the distiller across state lines into Maryland, thereby eliminating 200 jobs in West Virginia. ${ }^{102}$ Evidence suggests that the local decision makers and constituents who resided in border counties agreed with Senator Faulkner's assertions concerning the economic dangers of implementing statewide prohibition. Of the fifteen counties that still allowed liquor sales by the summer of 1881 , twelve bordered at least one other state. ${ }^{103}$

Jackson County's Judge Brown, the main supporter of the prohibition resolution, responded to Faulkner's lengthy speech by appealing to the rights of the citizenry to decide on the question. He reminded the assembled legislators that Mountain State petitioners were only asking the Senate for a chance to vote on the question, not to decide whether or not to ban alcohol. Senator Smith, another dry legislator, followed Judge Brown by listing intemperance's supposed evils and asking Ohio County Senator Woods to drop his motion for indefinite postponement. Smith claimed that he was willing to amend the bill and exempt wine and beer from prohibition. Woods denied the request, maintaining that such an alteration would create a bill that the people did not demand. The Ohio County senator's unwillingness to drop his motion, even when presented with a relatively generous exemption, suggests that Woods was confident in his side's majority. It also suggests that wets saw the possibility of prohibition legislation as a zero-sum proposition, just like their dry counterparts. Senator Faulkner closed

\footnotetext{
${ }^{101}$ Wheeling Register, February 17, 1881.

${ }^{102}$ Wheeling Daily Intelligencer, February 17, 1881.

${ }^{103}$ West Virginia Freeman, July 6, 1881.
} 
the day's proceedings, arguing that the resolution's advocates had failed to defend their position and reiterating the deleterious effects that a state prohibition law would exact on private industry. The debate on the prohibitory resolution would extend into the next day. ${ }^{104}$

The February 17 session convened in front of another large crowd of spectators. Within fifteen minutes of bringing the proceedings to order, the senators had dispensed with routine business and gravitated towards the pending order of indefinite postponement. Pro-resolution Senator McGregor, who had presented a petition from students at the Women's College as the day opened, fired the first volley in defense of state prohibition. He argued that the evidence presented by anti-resolution senators showing how ineffective prohibition was in other states came from newspaper articles and "that he considered newspaper reporters to be a very unreliable class, or in other words, he said they worked for the side that paid them the most." McGregor then presented his own set of statistics that he claimed vindicated the state prohibition system at work in Maine. ${ }^{105}$ Senator Dennis, speaking for indefinite postponement, responded to McGregor's assertions. Like many of the other anti-resolution senators, Dennis acknowledged the evils of liquor at the beginning of his remarks. Once he issued his temperance disclaimer, the Senator from Greenbrier County questioned the practicality and constitutional viability of the amendment. Since Congress was the only body that retained the right to regulate interstate commerce and the current amendment contained no order to ban the importation of liquor from other states, Mountain State prohibition would be rendered null once alcohol flowed in from neighboring states. Dennis also reminded the body that the state constitution allowed lawmakers

\footnotetext{
${ }^{104}$ Wheeling Register, February 17, 1881.

${ }^{105}$ Wheeling Register, February 18, 1881.
} 
to pass statutory prohibition at any time. ${ }^{106}$ Senator Brown responded with a reframing of the issue at hand. Brown asserted that the real question being debated was whether or not the people of West Virginia should be allowed to vote on a prohibitory amendment, not whether the amendment was "proper and right" or not. As the morning session closed, the Jackson County Senator reminded those in attendance that a simple prohibitory law, as advocated by Dennis, could be eliminated by the next legislative session and that "the people want the matter fixed for all time." 107

Debate on placing the resolution on the table continued in the afternoon session. Senator Dawson was the first to speak after the recess. While personally favoring local option as the best system of liquor control, he spoke against indefinite postponement, favoring the citizenry's right to vote on state prohibition. After establishing himself as a protector of the peoples' voice, Dawson attempted to refute the argument that the state would lose revenue in a prohibitionist regime. Interestingly, the senator advanced the same argument and cited almost exactly the same figures that Kanawha delegate Ferguson presented in his speech to the Fourth Street ME Church two weeks earlier. According to both politicians, the state paid nearly twice as much in felony case fees - many of these cases undoubtedly caused by liquor - as it received in license sales every year. ${ }^{108}$ It is clear in this case that, like the platform planks of the wets, pro-amendment talking points had been well established by the middle of February. Senator Dawson closed out

\footnotetext{
${ }^{106}$ Wheeling Register, February 18, 1881.

${ }^{107}$ Wheeling Daily Intelligencer, February 18, 1881.

${ }^{108}$ Both men claim that the state paid around $\$ 65,000$ in felony fees while it received either $\$ 35,000$ or $\$ 36,000$ in license revenue; Wheeling Daily Intelligencer, February 3, 1881, and Wheeling Daily Intelligencer, February 18 , 1881.
} 
his address by maintaining that the volume of petitions warranted the passage of the resolution to the people. ${ }^{109}$

After a brief speech made by another anti-amendment senator, Ohio County Senator Woods concluded the debate. He responded to Dawson by arguing, quite accurately, that the Senate was not obligated to abide by requests made in every petition they received. As the Intelligencer summarized Woods, "The Legislature has the right to use its discretion in the matter as to what shall be done and what not done."110 Additionally, the senator from Ohio County, like his counterpart from Greenbrier County, questioned the feasibility of enforcing state prohibition with five wet states bordering West Virginia. He also advanced the wet position in favor of local sovereignty. As the Register recapped, each county has the ability to allow or ban the sale of alcohol and "What right have the people of Ritchie County to say that Ohio County shall not grant licenses if they desire to? It is a local matter and foreign people have no right to interfere." Woods also echoed the private property argument advanced by Senator Faulkner, reminding his fellow legislators that the amendment provided no remuneration for the lost property of liquor interests. Finally, the Ohio County senator even expressed doubt about the authenticity of the thousands of petition signatures. He argued that the total number of petitioners was probably around 7,000 as "many of the names were signed in the same hand writing." 111

As debate on the resolution closed, Senators Woods and Brown engaged in a rather snippy exchange about comments made by Brown regarding the interests lobbying against

\footnotetext{
${ }^{109}$ Wheeling Daily Intelligencer, February 18, 1881.

${ }^{110}$ Wheeling Daily Intelligencer, February 18, 1881.

${ }^{111}$ Wheeling Register, February 18, 1881.
} 
passage of the bill. Once this unpleasantness ended, the senators killed the bill, voting fifteen to nine to postpone indefinitely its consideration. ${ }^{112}$ Perhaps it is appropriate that the two days of debate on Senate Joint Resolution Nine ended on such a discordant note. The 1881 session indicates that, with the possible exception of one senator's attempt to offer a compromise amendment to the law (and even this may have been designed to slow down the postponement effort), there was simply little middle ground between supporters and opponents of state prohibition. The Wheeling Register lamented this political reality in its February 18, 1881, edition, published one day after the death of the resolution. As the Democratic editors opined, the debate over the prohibitory resolution was "not properly an issue between temperance and intemperance, or between the friends of temperance reform and its enemies." Instead, while West Virginia drys risked marginalizing more moderate elements of the temperance issue by insisting on dictating policy and labeling those against the measures as enemies, "The issue presented is really one between the friends of license and the friends of prohibition, as methods of reforming the evils of the liquor traffic." The Register questioned the utility of a state prohibition law, citing prominent temperance agitators like Chancellor Crosby. Therefore, according to the editors, there existed "fair ground for a difference of opinion as to the expediency of inaugurating a policy of absolute prohibition when there is no general conviction or sentiment among the people which can guarantee the execution of it." There did not exist, however, "fair ground at all, for vituperation and abuse of men who claim the liberty of judgment and dissent from the extremists on these points."

\footnotetext{
${ }^{112}$ Wheeling Daily Intelligencer, February 18, 1881.

${ }^{113}$ Wheeling Register, February 18, 1881.
} 
Whether it is accurate to label nineteenth century Mountain State prohibitionists as extremists or not, there is little doubt that most of these activists reserved little space for gray area on the liquor question. To an extent, their very understanding of the inextricable link between God's law and man's government dictated that the Demon Rum be swept out of West Virginia as completely as possible. As was indicated by the proceedings of the 1881 legislative session, drys retained a considerable roster of political allies and advocates. While many of these politicians were not necessarily as bone dry as their constituents, they understood, like good elected officials do, that it was in their best electoral interest to advance the priorities of the enfranchised. Of the nine senators who voted not to postpone consideration of the joint resolution (a de facto vote for prohibition), only one - Senator Summers from Kanawha County - hailed from a county that would still be wet by the summer of $1881 .^{114}$ On the other hand, those engaged in the liquor and brewing industry, either directly or indirectly, also saw the prohibition debate in black and white. The end of the liquor trade meant the destruction of their business or their clients. In addition, for cities like Wheeling, a state ban on alcohol meant the dismantling of an entire industry, and its resulting tax contribution. Anti-prohibition politicians, while not necessarily as wet as their brewing industry patrons, also fought for their constituents' side of the issue because defeat in the legislature meant eventual defeat at the ballot box.

And then there was the great middle. While the prohibition issue made for great political theater in the late nineteenth century and the state's newspapers were more than happy to report the proceedings, the complex interplay between society, government, and sin simply did not retain the undivided attention of most West Virginians. The Register was correct in arguing that "there [was] no general conviction or sentiment among the people which [could] guarantee the

\footnotetext{
${ }^{114}$ West Virginia Journal and Bills, 1881, 142; delegates and senators are identified by county of residence in JC Dillon, ed., West Virginia Blue Book, 1976 (Charleston, WV: Jarrett Printing, 1976), 280-285, and 290-310.
} 
execution of [state prohibition] so as to protect such a law from contempt."115 In a time before Progressive-era notions of the perfectibility of man, Mountain State citizens were simply not ready for such a fundamental shift in their organic law, and neither were the men elected to represent their interests. As one West Virginia weekly pointed out, "It is believed that if the proposed amendment had been more limited in its scope it might have passed the Senate." 116 However, this blasé attitude toward social and political reform among the majority of West Virginians would not last forever. The 1881 defeat of state prohibition, while instructive in drawing the battle lines between wet and dry for the next thirty years, was certainly not the end of the road. As the Preston County Journal opined, "This question is and has been agitated by the people a great deal, and there is no doubt there is a great struggle in the near future on it." 117 Mountain State advocates of prohibition would only redouble their efforts, organize, and attempt to move the disinterested majority off their position in the moderate middle. Theirs would not be an easy road. Between 1881 and 1912, state-wide prohibitionists would endure more defeats than victories on their bumpy road to victory. While their increased activism and organization would certainly have a great impact on the eventual implementation of state prohibition, the changes, movements, and anxieties emerging both in West Virginia and around the nation in the late nineteenth and early twentieth century would also force the banishment of legal drink forward in the Mountain State's public and political discourse until its residents were finally ready to attempt the noble experiment.

\footnotetext{
${ }^{115}$ Wheeling Register, February 18, 1881.

${ }^{116}$ Preston County Journal, February 24, 1881.

${ }^{117}$ Preston County Journal, February 24, 1881.
} 
CHAPTER THREE: Welding the Phalanx: Organization, Early Coordination, and the Road to West Virginia State Prohibition, 1881-1890s

\begin{abstract}
The only consistent position that a Christian can take on the subject [of liquor] is total abstinence as a beverage for himself, moral suasion for his family and church, and legal prohibition for his country. We hail with delight the growing sentiment all over the country in favor of legal prohibition, and we pledge ourselves not to relax our efforts in this direction until we have secured for our beloved mountain State an amendment to its Constitution forever prohibiting the manufacture and sale of intoxicants as a beverage. ${ }^{1}$
\end{abstract}

A few days after the death of the 1881 prohibition resolution, the Freeman Publishing Company released the first edition of its temperance newspaper, the West Virginia Freeman, out of its Parkersburg office. While attempting to assume a modest posture, the weekly organ's editor, I.H. Johnson, could barely conceal his confidence: "Its coming calls for no apology. If there be room for it [the paper], it has a freeman's right to come, and proffering its labors, prefer its claims. If there be no room for it, it is humble enough to believe, "twill be its own fault." 2 The paper's staff was clear about their goals and agenda. According to the first edition's editorial page, "It will therefore come boldly and aggressively, bearing the flag of Prohibition [their emphasis]; and whether advancing successfully or meeting seeming repulse, will proclaim for every temperance measure."3

\footnotetext{
${ }^{1} 20^{\text {th }}$ Annual Session of the Baptist General Association of West Virginia, Held at Charleston, WV, November 6 to 9 , 1884 (Akron, OH: Beacon Publishing, 1884), 23.

${ }^{2}$ West Virginia Freeman, February 23, 1881.

${ }^{3}$ West Virginia Freeman, February 23, 1881.
} 
With an initial printing of only 1,000, the Freeman's publishers quickly endeavored to build the organ's audience throughout the state by making copies available to local newspapers. Johnson reprinted the thoughts of other editors in his March 9, 1881 edition. It is reasonable to assume that the editor chose only the most favorable input from the Mountain State's other editorial pages. Most of the newspapers listed complimented the Freeman's content, formatting, and intentions. The Marietta $(\mathrm{OH})$ Register, however, expressed concern over the possible dominance of the temperance issue within the newspaper's pages. The Buckeye State editor asserted that the Freeman would gain enough statewide subscriptions to make up for its loss of local interest within Parkersburg due to its largely temperance-oriented message. While the Register expressed its support for the fledgling publication, it also hoped that "Johnson [would] have the discernment so seldom found in Temperance papers, to guard against too much Temperance preaching." ${ }^{4}$ I.H. Johnson commented on the Register's input by reiterating his paper's unabashed support for the dry cause. The prohibitionist editor expressed his gratitude and commented that "You do not mean to warn us against preaching Temperance too much, but against preaching other virtues too little. We'll try to profit by the suggestion."

In the eyes of Johnson, his weekly filled an important editorial void in West Virginia's news media. The editor argued that local papers operating within the state owed their allegiances to any number of special political or industrial interests and were not designed for statewide circulation. Denominational organs, on the other hand, "have a ... religious purpose to serve, and cannot pay much attention to, or devote much of their valuable space to temperance

\footnotetext{
${ }^{4}$ Quoted in West Virginia Freeman, March 9, 1881.

${ }^{5}$ West Virginia Freeman, March, 9, 1881.
} 
literature. ${ }^{\circ 6}$ The Freeman, therefore, could be a success precisely because it was not a local paper or religious weekly. Johnson asserted that "there is . . a vacuum of sufficient size to admit an independent weekly newspaper, of decided temperance proclivities. We lay to our soul the flattering unction that Freeman is just such a paper as this." Additionally, the Freeman could be a special interest publication in the purest sense, free from the influences that prevented other newspapers from focusing on ending the liquor trade. As the editor proclaimed, "With the Freeman there is no axe to grind [their emphasis] - no party to serve - no denominational interests to superintend - no local specialty to write up." This left the paper free "to devote itself to one work - the victory of the temperance cause in the State of West Virginia." Perhaps most importantly, the Parkersburg publication, according to the editor, would serve as a de facto philosophical and organizational exchange for temperance elements throughout the state. Ideas, arguments, and events from West Virginia's widely divergent dry forces could be disseminated on the statewide level and "aid us to obtain a uniformity of sentiment, perfect our organization, systematize all of our work, husband our strength, [and] strike no aimless and useless blows."7 Delegates at the 1881 West Virginia State Temperance Convention, which Johnson attended, apparently agreed with the Parkersburg editor. The Committee on Press and Literature, recognizing "the necessity of a common medium of intercourse between the various sections of the State, to secure harmony of purpose and unity of action," acknowledged the Freeman and asked attendees to support and contribute to the weekly. In its report, the Executive Committee officially approved and sanctioned Johnson's publication. ${ }^{8}$

\footnotetext{
${ }^{6}$ West Virginia Freeman, March 16, 1881.

${ }^{7}$ West Virginia Freeman, March 16, 1881.

${ }^{8}$ Quoted in West Virginia Freeman, July 6, 1881.
} 
Although I.H. Johnson's paper never reached mass circulation and only lasted a little over seven years, the efforts of the West Virginia Freeman comprised an instructive philosophical and operational turning point between the almost constant failures of the mid to late nineteenth-century dry movement and its eventual legislative and electoral success in the early twentieth century. ${ }^{9}$ This is not to suggest that this publication was the main reason that prohibitionist sentiment eventually won over a majority of enfranchised West Virginians between 1881 and 1912. However, in its calls for greater bipartisan and nondenominational organization and statewide communication and activism, this small, independent paper out of Parkersburg previewed the style of agitation that, along with a number of other national and state-level factors and changes, would eventually win the battle for statewide prohibition.

In essence, the West Virginia Freeman operated like the Anti-Saloon League (ASL) years before that transformative body even existed. Unfortunately for the Freeman's readers and other West Virginians who wished to impose their vision of social perfection on the Mountain State, foreshadowing the future strategies of the more successful ASL was not the same thing as actualizing these approaches. The ASL was not yet present in the 1880s and early 1890 s, and the fundamental political, social, and economic changes that would sow a much more fertile field for prohibitionist agitation around and after the turn of the twentieth century had not yet fully transformed the Mountain State and its people.

Ultimately, then, the period between 1881 and the 1890 s is one of continued, late-1800s legislative disappointments, the resounding defeat of statewide prohibition in 1888 , continuing organizing efforts, and the beginning of incremental prohibitionist victories around the turn of

\footnotetext{
${ }^{9}$ Precise circulation of the Freeman is hard to determine, but existing evidence suggests that the paper's subscription-based circulation never exceeded several thousand copies. The Freeman collection in the WVRHC abruptly ends on December 19, 1888 - perhaps not ironically only a few weeks after the 1888 prohibition amendment referendum failed in November.
} 
the twentieth century. "Welding the Phalanx" provides a necessary overview of the last two decades of the nineteenth century and sets the stage for the victory of statewide prohibition in 1912. While Mountain State drys ultimately failed to reach their final destination in the 1880 s and 1890s, they learned cooperation, gained valuable experience in the legislative realm, founded new organizations, and settled on a more incremental strategy that would eventually propel them to prohibitionist victory a little over a decade into the twentieth century.

Mountain State prohibitionists must have privately believed that their ultimate goal of a statewide antiliquor law was as far away as it ever had been in the days and weeks after the indefinite postponement of Joint Resolution Nine. After all, while members of the Senate had cast symbolic votes for and against the resolution's tabling, supporters of state prohibition must have felt the outcome anticlimactic as there was no official up or down vote, in spite of their best efforts. However, West Virginia Freeman editor I.H. Johnson did not allow a post-session pall to depress dry forces in the spring of 1881. In his March 23 edition, Johnson lauded the efforts of Jackson County State Senator and dry political leader Judge Brown during the 1881 debates, refuting wet charges of fanaticism and describing Brown as "a worthy champion of the people." Additionally, the editor immediately attempted to turn his audience's attention to the adjourned legislative session to be held in January 1882. Johnson charged his readers with the task of using the time before the 1882 session to urge their representatives to pass a prohibitory law. As the editor pleaded, "Go to them kindly, but earnestly, and beg them in the name of God, in the name of humanity, in the name of the suffering women and children, to let the people say, whether this traffic shall be tolerated or not."10

\footnotetext{
${ }^{10}$ West Virginia Freeman, March 23, 1881.
} 
Attempts at activism and organization were not solely rhetorical in the months between the 1881 and 1882 legislative sessions. The April 6, 1881, Freeman published a short report on the Parkersburg meeting of a "State Temperance Executive Committee." While evidence suggests that this was not the first meeting of this body, its lofty goals nonetheless comprise a significant evolution in the strategy and organization of the dry movement in West Virginia. This body operated a lot more like a central or steering committee for a larger, statewide movement than an individual special-interest or religious group. Convened with board members from all over the state (many of them hailing from rural counties), the executive committee set a date for the 1881 State Temperance Convention (June 28), invited "all Temperance organizations within the state" to join the cause and attend the convention, and voiced support for the West Virginia Freeman. Most importantly, though, they announced that they would recommend at the convention that every Mountain State county "appoint one or more agents to thoroughly organize the Temperance work ... during the Summer and Fall" and issued a resolution that every county and locality should be urged to call their own temperance meetings and send delegates to the state convention. ${ }^{11}$

The State Temperance Convention, convened on June 28 at the Fourth Street ME Church in Wheeling, must have appeared quite different from the usual political, social, or religious mass meetings of the time because of its relative diversity. Freeman editor Johnson, who published a record of the convention's proceedings in the July 6 issue, observed the crowd gathered on the Emma Graham, steaming from Parkersburg to Wheeling: "There were democrats, republicans, greenbackers, Methodists, Baptists, Presbyterians, etc, lawyers, farmers, editors, railroad men, and men of all classes, and ladies, old and young." Indeed, Johnson

\footnotetext{
${ }^{11}$ Quoted in West Virginia Freeman, April 6, 1881.
} 
counted thirty-four delegates from eleven counties spread from Tyler all the way down to Summers on his boat alone. ${ }^{12}$ While the social, religious, and political diversity of the attendees is noteworthy, their singular and ambitious devotion to a single cause is more important. Instead of a group of WCTU members issuing resolutions or urging petitions on behalf of the WCTU or a collection of West Virginia Baptists doing the same on behalf of the Baptist church, the Wheeling conventioneers pushed for a streamlined, statewide movement that would, indeed, weld disparate Mountain State denominational and organizational interests into a unified, prohibitionist phalanx. Convention leadership understood that this kind of campaign would need to spring up from local grassroots. In fact, the first statement that the convention's temporary chairman made was that "we are here to effect a permanent organization in every county and district in the State. We have met to work - to organize for work, for action and for voting, not for speech-making."13

In its report to the conference body, the state temperance executive committee simultaneously admitted to the current condition of the prohibitionist movement in West Virginia and reassured the conventioneers that there existed a burgeoning anti-liquor feeling in West Virginia. Pointing to the increasing number of no-license counties, Chairman Dave Johnson maintained that "while only limited progress has been made in the work of organization, we mark with extreme satisfaction the rising sentiment of Prohibition throughout the State." To encourage better coordination and to make the most of the growing dry sentiment, conference attendees formed seven separate committees, including those on Credentials, Permanent Organization, County Organization, State Agents, Petitions and Canvasses of the State, Press and

\footnotetext{
${ }^{12}$ West Virginia Freeman, July 6, 1881. I.H. Johnson not only attended the convention, he was named the Secretary pro tem.

${ }^{13}$ Quoted in West Virginia Freeman, July 6, 1881.
} 
Temperance Literature, and Time and Place of the Next Meeting. ${ }^{14}$ A number of these groups presented noteworthy reports and resolutions to the conference. For example, the Petitions Committee, in addition to calling for the drafting and dissemination of a prohibitionist petition for the 1882 session, apparently responded to wet allegations by requesting "that all petitions be so certified as to leave no doubt as to the fact of their having been signed by qualified voters." Conference members unanimously adopted the report once the committee added an amendment to the resolution requiring actual signatures on the petitions when possible. ${ }^{15}$

Delegates also decided to include female prohibitionists as they accepted and acted on the Press and Literature Committee's recommendation to name three women to "a Central Committee on Temperance Literature" in Wheeling. Members charged these activists with disseminating "approved temperance literature" through existing dry organizations. ${ }^{16}$ Convention delegates issued six resolutions as their meeting approached its conclusion on June 29. The statements echoed many of the positions assumed by other West Virginia organizations. They decried the liquor trade as "the greatest evil," accepted prohibition as the remedy, pledged energy and funds, asked state politicians to authorize the prohibition amendment during the 1882 session, urged cooperation from all dry groups, petitioned Sunday School teachers to lecture on abstinence, and challenged Mountain State young people "to sign the abstinence pledge."17

While convention delegates may have left Wheeling filled with vim and vigor that midsummer evening, their collective will had chilled as quickly as the winter air in late January. I.H. Johnson lamented the lack of focus and effort on the part of dry forces as their second chance at

\footnotetext{
${ }^{14}$ Quoted in West Virginia Freeman, July 6, 1881.

${ }^{15}$ Quoted in West Virginia Freeman, July 6, 1881.

${ }^{16}$ Quoted in West Virginia Freeman, July 6, 1881.

${ }^{17}$ Quoted in West Virginia Freeman, July 6, 1881.
} 
constitutional prohibition approached with the opening of the 1882 adjourned session.

According to the Freeman's editor, "We regret very much that many friends of the cause

throughout the State have been too careless about circulating and returning petitions." ${ }^{, 18}$ In spite of the carelessness of some dry activists, Johnson struck a pensively hopeful tone as House Joint Resolution Number Eight began its voyage through the House of Delegates. According to the editor, "It seems to be conceded that it will receive the requisite two-thirds in the House. But its fate is uncertain in the Senate." While "the Legislature would have been buried under thousands of names" had the allies of prohibition been more attentive to their cause, Johnson still maintained that most politicians were aware of the people's desire for submission of the amendment. ${ }^{19}$

Petitions from around the state still reached the house chambers as the vote on the resolution neared. The Register noted that delegates presented ten separate petitions from county residents and religious bodies on January $31 .^{20}$ The Freeman reprinted a number of comments from other state newspapers in its February 1 edition. Of course, all of these excerpted editor's notes, whether in favor of statewide prohibition or not, at least supported the submission of the resolution to the people. The Fayette Enterprise, for example, opined that "the quickest and best way to dispose of the Prohibition Amendment is for the Legislature to submit it to the people." While the Weston Democrat doubted the chances of the amendment if submitted to the people, its editors nonetheless backed submission: "No member commits himself to the advocacy or support of the measure by voting to submit it ... the large and respectable number that have

\footnotetext{
${ }^{18}$ West Virginia Freeman, January 25, 1882.

${ }^{19}$ West Virginia Freeman, January 25, 1882.

${ }^{20}$ Wheeling Register, January 31, 1882.
} 
petitioned for its submission, have rights that should be recognized by the Legislature."21 Not all Mountain State newspapers were supportive, even conditionally, of House Resolution Eight. On the same day as the Freeman's reprinting of positive press coverage, the Democratic Wheeling daily, the Register, launched a three-pronged attack on the possibility of a state prohibition amendment. The Register's editors did not attempt to deny the existence or evils of intemperance, nor did they refute the need to suppress drunkenness. Rather, they wished to consider "whether the proposed amendment is a proper measure for the suppression of the evils." ${ }^{22}$ In their estimation, it was not.

According to the editors, "Viewed from the standpoint of public policy, the proposed amendment strikes us as unwise and unnecessary." 23 In the eyes of the Register, a statewide prohibitory law was nothing more than a moralistic attempt at fixing human behavior, had done nothing in any state to alleviate intemperance, and ignored the fact that a clause already existed in the state constitution providing for the imposition of statutory prohibition. Much like their neighbors in the dry press, the detailed arguments presented by the editors of the Register virtually mirrored the standard talking points advanced by their allies in the public and political realms. Focusing on the concept of personal freedom, the Register argued that the amendment was “an attempt to either abolish a man's appetite by statute, or to deprive him of his individual liberty to indulge that appetite in any degree whatever. You must change the nature of man before you can accomplish either of these ends by such a process." 24 In addition to advancing the personal liberty argument and pointing to the failure of state prohibition in other states

\footnotetext{
${ }^{21}$ Quoted in West Virginia Freeman, February 1, 1882.

${ }^{22}$ Wheeling Register, February 1, 1882.

${ }^{23}$ Wheeling Register, February 1, 1882.

${ }^{24}$ Wheeling Register, February 1, 1882.
} 
(something that anti-prohibition politicians did during the 1881 floor debates), these Northern Panhandle wet journalists also attacked a prohibitory constitutional amendment as "absolutely without excuse, unnecessary, superfluous, and vexatious." Echoing the common wet refrain that prohibitionists did not need a constitutional amendment because they could pass a prohibitionist law at any time, the Register asserted that the state's founding fathers had placed a clause enabling legal prohibition because they "wisely considered that a prohibitory liquor law was better as an act of the Legislature than as a constitutional provision." In the eyes of these wets, the imposition of a more permanent form of state prohibition via amendment was far too risky: "We submit that prohibition in West Virginia ... is too serious an experiment to put in the constitution, beyond the power of repeal by the Legislature." 25

Most delegates disagreed with the Register's opinion as they came quite close to passing House Joint Resolution Eight during the 1882 adjourned session. Delegates treated the resolution as carryover business from the 1881 session where legislators offered repeated amendments and eventually tabled the legislation towards the end of the session. ${ }^{26}$ Unlike their counterparts from the prior session, who were virtually split on the issue, the 1882 house members seemed more willing to pass the prohibition experiment on to the senate. Resolution eight failed by a slim margin of forty votes for and twenty against. While forty to twenty appears to comprise the two-thirds margin necessary for passage of amendments, several absences and vote pairings kept the number under the "two-thirds of all the members elected to

\footnotetext{
${ }^{25}$ Wheeling Register, February 1, 1882.

${ }^{26}$ Journal of the House of Delegates of the State of West Virginia for the $16^{\text {th }}$ Session, 1881 (Wheeling, WV: Johnston Printing, 1881), 272-273.
} 
the House." 27 Mountain State drys, who had come as close as they ever had to passing a prohibitory amendment through at least one chamber of the state legislature, were again forced to defer their dream for another year. In the February 8 edition of the Freeman, published only a few days after the amendment's defeat, I.H. Johnson could not contain his disappointment. He lamented the slim margin and the lost votes caused by legislative absences, vote swaps, and parliamentary maneuvers and alluded to "the questionable methods resorted to, to defeat the Amendment." Additionally, the editor rebutted, in a spirited, point-by-point response piece, the Wheeling Register's anti-prohibition column, which he considered to be "a fair compendium of the arguments used against prohibition." 28 In typical Freeman fashion, however, the tone remained upbeat in the face of yet another prohibitionist defeat. After all, as Johnson reminded his readers, "Remember that we are now on the eve of another election, which will send up an entire new House of Delegates, and twelve Senators.” In his eyes, the legislators who voted against the resolution operated on borrowed time: "While these twenty upon their return are being feasted by saloon-keepers . . . the temperance and Christian people of the State will ... press on to the certain victory that always comes to the right in the fullness of time." ${ }^{29}$

Johnson's argument, while tinged with the language of his movement, is a reasonable and apt description of the circumstances under which House of Delegates members operated, and still operate, in the West Virginia legislature. In addition, his comments begin to explain why delegates may have come closer to passing a prohibition amendment on to the people than their senatorial counterparts. Elected every two years, Mountain State delegates needed to be careful

\footnotetext{
${ }^{27}$ Journal of the House of Delegates of the State of West Virginia, for the Adjourned Session, 1882 (Wheeling, WV: Johnston Publishing, 1882), 170-171.

${ }^{28}$ West Virginia Freeman, February 8, 1882.

${ }^{29}$ West Virginia Freeman, February 8, 1882.
} 
about how they voted on potentially explosive issues. Prohibitionist sentiment was not a majority opinion in most West Virginia counties, especially in the pre-progressive 1880s. However, prohibitionists were becoming an increasingly powerful and organized special-interest group that wise delegates could not afford to ignore or offend. House of Delegates members were, by definition, closer to their constituents. This may begin to account for why some lowerhouse legislators voted for submission of the amendment or avoided the vote as best they could. Ultimately, though, these explanations can only be extended so far. After all, the House of Delegates did fail to pass the resolution. Additionally, delegates enjoyed the dual political luxury of passing the bill on to the senate if it did pass, thus exonerating them from ultimate responsibility, and invoking the argument that a vote cast for submission was a reflection of their desire to protect the democratic rights of their constituents and not an indication of their true position on the issue.

Johnson, of course, cared little about the functional and philosophical differences between the state house and senate. His only interest was securing a prohibition-friendly legislature in the next election. The editor revealed this goal on the eve of the 1882 State Temperance Convention, declaring that the meeting's "pressing and imperative duty" should be focused on "unifying and directing the temperance vote of the State in the election of the representatives to the next legislature who will serve the people who elect them and not insult them by spurning and spitting on their righteous petitions." 30 West Virginia Baptists and Methodists echoed the Freeman's calls for greater political coordination during their fall 1882 conferences. ME members resolved, among other items including a support declaration for the Freeman, "that a central committee be appointed by this conference to have the general oversight

\footnotetext{
${ }^{30}$ West Virginia Freeman, June 13, 1882.
} 
of the work and to secure more thorough organization among ourselves and concert of action with other religious bodies and temperance societies."31 Mountain State Baptists also expressed their support for the Freeman and for the ME Church's recent decision to appoint a central temperance committee and directed the association president to name a Baptist central committee, which would be charged with cooperating with the Methodists. ${ }^{32}$

Religious bodies and other organizations had certainly already taken clear positions against liquor earlier in the nineteenth century. However, one cannot help but notice the growth of a rudimentary, almost skeletal, organizational structure in West Virginia during the 1880s. It was one thing when independent and religiously affiliated groups shouted temperance slogans in the wilderness. It was quite another thing when these groups began to read temperance papers, attend statewide temperance conferences and cooperate with each other via central organizing committees. While this arrangement paled in comparison to the confederations that operated after the emergence of the ASL and during the successful ratification campaign of 1912, it nevertheless presaged the eventual development of the coordinated and cooperative specialinterest movement that prohibition became in the Mountain State in the late nineteenth and early twentieth centuries. $^{33}$

The opening of the 1883 regular legislative session afforded members of the movement their third chance at constitutional prohibition in as many years. Both the House of Delegates

\footnotetext{
${ }^{31}$ Minutes of the West Virginia Conference of the ME Church, Held at Clarksburg, West Virginia, October 4-9, 1882 (Akron, OH: Beacon Publishing, 1882), 36.

${ }^{32}$ Minutes of the Baptist General Association of West Virginia, Session of 1882, $19^{\text {th }}$ Annual, Held at Hinton West Virginia (Parkersburg, WV: George Elletson, Printer, 1882), 20.

${ }^{33}$ Szymanski refers to the successful efforts of the West Virginia Ratification Federation in the 1912 campaign; Ann-Marie Szymanksi, Pathways to Prohibition: Radicals, Moderates, and Social Movement Outcomes (Durham, NC: Duke University Press, 2003), 158-159.
} 
and state senate remained in the hands of the Democrats for the 1883 session. ${ }^{34}$ West Virginia prohibitionists, however, were not concerned about the composition of the legislature, especially after their near miss during the 1882 session. As the legislature convened, papers of various leanings handicapped the interest in and chances of another prohibitory bill. The Morgantown New Dominion did not consider prohibition a major issue in its editorial covering the opening of the 1883 legislature: "It is the general feeling that the session will be a short one. The election of a Senator and the passage of the appropriation bills are the most important matters that need attention." 35 Other papers acknowledged what they considered to be the importance of constitutional prohibition. The Point Pleasant Register considered a prohibitory bill "among the most important" and noted, perhaps not surprisingly, that opinions on the measure's ultimate fate depended on where one stood on the issue. ${ }^{36}$ Dave Johnson, reporting from Wheeling, assumed a confident tone in his report to the West Virginia Freeman. The Chairman of the State Temperance Executive Committee asserted that "the outlook for the Amendment is very hopeful. We count forty-seven Delegates who have given positive assurance that they will vote for it. Two or three more pledged that they would do so." He was also sure that the senate would join the house in supporting the measure. ${ }^{37}$

The confidence of prohibition leaders did not compel them to rest on their laurels as the session approached. Perhaps because of their experience in 1882, because of their zeal, or because they chose not to be disappointed by another grassroots petition drive, men like Dave

\footnotetext{
${ }^{34}$ Legislature of West Virginia: Manual of the Senate and House of Delegates, Seventy-Eighth Legislature, 20072008 (Beckley, WV: BTW Printing and Office Supplies, 2008), 416 and 480.

${ }^{35}$ Morgantown New Dominion, January 13, 1883.

${ }^{36}$ Quoted in West Virginia Freeman, January 10, 1883.

${ }^{37}$ West Virginia Freeman, January 17, 1883.
} 
Johnson decided to flood the halls of the state capital with documents containing what they considered to be logical and compelling arguments in favor of state prohibition. The State Temperance Executive Committee submitted a prohibitionist memorial to the legislature early in the 1883 session. This document included succinct discussions of most of the dry movement's standard talking points and ended with the following plea:

Wherefore, in view of the unusual importance of this great question, convinced as we are that it is a question particularly appropriate for the consideration and decision of the sovereign people of the State, and believing that when the people desire it, they have a RIGHT to be heard upon a matter of such vital importance, involving as it does the peace and security of the State, the welfare of families, and the happiness of every home, we respectfully entreat you, that you will grant us this our urgent petition. ${ }^{38}$

Committee members also included with the petition excerpts from a variety of political and religious groups that supported at least the submission of a prohibitory amendment to the citizens. The usual cadre of Protestant religious groups comprised many of the attached resolutions. Political parties also lent their support. In a resolution issued at their convention, for example, the Greenback Party criticized the 1882 legislative session for ignoring "the wishes and desires of a large number of the voters and people of the state." County and district Republican Party conventions either threw their full support behind the amendment and its submission or at least defended the right of Mountain State citizens to decide on the issue themselves - a position proffered by most county and district Democratic Party conventions. ${ }^{39}$

House Joint Resolution Number 11 emerged on January 16, 1883. Read for the first time on the following day, the measure was effectively the same bill offered in the senate in 1881. It

\footnotetext{
${ }^{38}$ Quoted in West Virginia Freeman, January 17, 1883.

${ }^{39}$ Quoted in West Virginia Freeman, January 17, 1883.
} 
called for the permanent prohibition of "the manufacture, sale, and keeping for sale of all intoxicating liquors, drinks, mixtures, and preparations" and the establishment of enforcement laws. ${ }^{40}$ A similar resolution was working its way through the senate at the same time. Its sponsor, however, opted to lay his bill on the table in favor of Resolution $11 .^{41}$ Senator Hays' decision to yield to the house resolution, while not necessarily stated directly, was probably made because the politician realized that prohibitory legislation had been more successful in the legislature's lower house. Delegates read Resolution 11 for a second time on January 23 and made it the special order of the day for the morning of Thursday, January $25 .{ }^{42}$ As the legislation journeyed through the House of Delegates, journalists at the West Virginia Freeman commented on the scene around the Capital in Wheeling. They reported with satisfaction a mass temperance meeting held at Washington Hall on Sunday, January 21, where "a magnificent demonstration of the enthusiastic sentiment of the best people of the city in favor of prohibition" occurred. Prohibitionists also attended a pro-amendment rally at the Fourth Street ME Church later that evening. While the Freeman beamed with pride at the outpouring of dry sentiment among the "best" residents of Wheeling, it leveled charges of corruption against wet elements and their political allies. According to the prohibitionist weekly, politicians and liquor agents were busy manipulating, propagating lies, and even buying influential allies: "A fee of $\$ 1000$ from the liquor men, to a prominent lawyer from a distant part of the State, to lobby [their emphasis]

\footnotetext{
${ }^{40}$ West Virginia Journal and Bills of the House of Delegates, 1883 (Wheeling, WV: Public Printers, 1883), 51. The bill is identified as House Joint Resolution 11 in Wheeling Daily Intelligencer, January 26, 1883.

${ }^{41}$ Spirit of Jefferson, January 23, 1883.

${ }^{42}$ Journals and Bills of the House, 1883, 94.
} 
against the prayers of his own people and against the homes of his own clients - this is how it is done!"

While the charges made by the Freeman were certainly incendiary, they were nothing compared to the war of words waged by pro and anti-amendment forces as the resolution reemerged on January 25. Delegates on both sides of the issue presented similar arguments to those offered during the 1881 senate debates. However, with the House of Delegates' near miss at the end of the 1882 and the dry movement as strong as ever, anti-prohibition legislators were in the distinct majority. Five delegates, four of whom represented the Northern Panhandle counties of Ohio and Wetzel, quickly established themselves as the key voices against either state prohibition as a whole or the resolution as it was written. While Delegates Burtt of Ohio County and Hall of Wetzel County eventually relented and voted for the bill, Ohio County Delegate Stifel and Speaker Woods, along with Pendleton County representative Pennybacker, rejected Resolution 11 and fought it until the bitter end. ${ }^{44}$ In essence, these five delegates fought a rear-guard action against the amendment by either attempting to exempt their home districts from prohibition, thus mitigating the law's impact on Wheeling, or by killing the bill as a whole. Delegate Burtt attempted to amend the resolution by exempting Ohio County from state prohibition if it voted against it in a referendum. Hall upped the ante on Burtt's amendment by offering a revision that would excuse any county deciding against prohibition. The dry delegates responded with utter rejection. One legislator even said that "he would rather see the resolution defeated than have it modified as proposed." Ultimately, both amendments went down in flames

\footnotetext{
${ }^{43}$ West Virginia Freeman, January 24, 1883.

${ }^{44} 1883$ session politicians are identified by county in the West Virginia Freeman, January 31, 1883, and June 4, 1884; the House of Delegates vote count is provided in the West Virginia Freeman, January 31, 1883.
} 
as the Ohio County exemption failed forty-eight to fourteen and the wet county exemption failed forty-six to seventeen. ${ }^{45}$

Delegate Stifel took his own shot at the resolution by requesting a change in the law's preamble. He wanted the word "proposed" replaced with "agreed to" so that the law would read "that the following amendment is . . hereby agreed to." The representative from Ohio County argued that this change would make the bill more constitutionally viable and would "put the members who voted for the amendment on record as agreeing to it." Faced with losing the political cover provided by maintaining that a vote for the amendment was simply a vote to give the people the right to vote, the house rejected the amendment forty-nine to thirteen. ${ }^{46}$ Pendleton County Delegate Pennybacker decided that a more acerbic approach was necessary to drive his anti-amendment point home. He offered an amendment that would have included a prohibition on tobacco products along with alcohol. Pennybacker dryly observed that the current Legislature was "very moral and religious" and that tobacco was worse than alcohol. House Speaker Woods also chipped away at Resolution 11 by presenting an amendment that would have reimbursed liquor interests for their lost investments under a prohibitionist regime. Both adjustments failed in the overwhelmingly dry assembly as Pennybacker withdrew his motion and Woods' proposal failed. The delegates sent the measure to its third reading as the special order of the day on

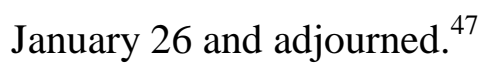

While bickering and maneuvering continued over the next few legislative days, the house's prohibition resolution passed on to the senate on January 30 by a vote of forty-nine for to

\footnotetext{
45 Journal and Bills of the House, 1883, 110-113; Wheeling Daily Intelligencer, January 26, 1883.

${ }^{46}$ Wheeling Daily Intelligencer, January 26, 1883; Wheeling Register, January 26, 1883.

${ }^{47}$ Wheeling Daily Intelligencer, January 26, 1883.
} 
fourteen against. ${ }^{48}$ In hindsight, the prognostications of the Freeman's Dave Johnson at the beginning of the house debates were right on the money. More importantly, however, the final vote confirmed that the majority in favor of the bill's submission was overwhelming. Additionally, this dry phalanx held together remarkably well throughout most of the debates as the margins against the wet amendments were virtually identical to the final vote. This seeming unanimity did not, however, extend to the realm of the West Virginia press as the amendment made its way from the House of Delegates through the state senate. Mountain State newspaper readers, especially those in the northern panhandle at the center of the controversy, witnessed a brutal editorial conflict that rivaled the war of words in the legislature. In its January 10 issue, the Freeman stated confidently that "a large majority of the newspapers in the State are outspokenly in favor of conceding this enevitable [sic] right of the people without further delay, while no paper has the brazen boldness to oppose it."49 Three weeks later, however, the prohibition organ's staff conceded that they might have spoken too soon. The Register, Wheeling's Democratic daily, had come out aggressively against state prohibition. By the January 31 issue of the Freeman, the Register was the enemy of all things dry in West Virginia. According to I.H. Johnson and his staff, "the Wheeling Register, almost alone of all the hundred papers of West Virginia, defiantly strides forth as the Goliath of Alcoholic Gath, to fight the battles of the whisky Philistines.",50

In its January 26, 1883 issue, the Register clearly presented its position on the pending prohibition amendment: "In the interest of temperance and good society, we should be glad to

\footnotetext{
48 Journal and Bills of the House, 1883, 133-134.

${ }^{49}$ West Virginia Freeman, January 10, 1883.

${ }^{50}$ West Virginia Freeman, January 31, 1883.
} 
see the bill defeated, and in its stead a much more stringent license law enacted." The editors further expressed concerns about the forty-one dry counties imposing their will on the thirteen wet counties, presented testimony about the negative experience of state prohibition in Kansas, and defended Delegate Hall's wet county exemption - accusing any legislator who voted against the amendment of "hypocracy [sic] and demagoguery." ${ }^{.51}$ The Register's editorial page contained more attacks on the prohibition movement the next day. This time, the editors assailed the moderate dry position that one could vote for submission to the people while personally rejecting the enforcement of state prohibition. As the Democratic journalists argued, this cautious political position smacked of a “'double-entendre' style of statesmanship.” They also corrected Jackson County dry Delegate Armstrong's suggestion that the paper was pressuring the House of Delegates to adjourn in order to kill the resolution. Reiterating their objection to the bill, the editors maintained that they actually wanted "the Legislature [to] vote down the proposed amendment with as little delay as possible and then adjourn." ${ }^{, 52}$ The Republican Wheeling Daily Intelligencer, which favored submission of state prohibition to the people, printed a letter to the editor on January 27, accusing the Democratic daily's correspondent of fraud and plagiarism. ${ }^{53}$ According to "Admirer," the Register staff writer who traveled to Maine to cover state prohibition and found that state prohibition was a success there, reprinted a New York newspaper's report on the failure of prohibition in Kansas instead. Additionally, "Admirer" alleged that the Register had printed what they claimed to be a dispatch from the

\footnotetext{
${ }^{51}$ Wheeling Register, January 26, 1883.

${ }^{52}$ Wheeling Register, January 27, 1883. Armstrong is identified as being from Jackson County in West Virginia Freeman, January 31, 1883.

${ }^{53}$ The newspaper reiterated its position on the amendment in Wheeling Daily Intelligencer, February 7, 1883.
} 
Governor of Kansas on the subject of prohibition when the content was eerily similar to the Governor's inaugural address, which West Virginia Governor Jackson had on his Capital desk. ${ }^{54}$

Even after the amendment passed the House of Delegates by an overwhelming margin, the Register doubted the legitimacy of the lower house's decision. Reminding their readers that a number of delegates spoke out against the measure before voting for it, the editors argued that "they passed [the resolution] to get rid of it." In addition, according to the Democratic daily, the delegates "have given their consent to the submission of the resolution to the people, who take no stock in it and, we believe, represent the feelings of a majority of the members, and a majority of whom will not hesitate to vote against it at the polls." ${ }^{55}$ While the Register rapidly descended into the realm of the shrill toward the end of the 1883 session, there indeed existed strong voices against the measure in the senate. On February 6, Mineral County Senator Price criticized those who used the prohibition resolution as a "test of Christianity" and maintained that every law did not need to be run through the people. Additionally, he rejected the dry argument that one could be against the bill and favor submitting it to the people and denounced the use of women in the political arena via the prohibition movement, accusing activists of disturbing "the fundamental principles of society, as established by the Maker of Heaven and Earth.” Senator Smith, of Marion County, took the opposite position as he reminded the Senate body that elected officials work for the people and asserted that a "higher and better class" of citizen supported the amendment. $^{56}$

\footnotetext{
${ }^{54}$ Wheeling Daily Intelligencer, January 27, 1883.

${ }^{55}$ Wheeling Register, January 31, 1883.

${ }^{56}$ Wheeling Register, February 7, 1883; Senator Price is identified as from Mineral County in West Virginia Freeman, June 4, 1884.
} 
On the morning of February 7, 1883, House Joint Resolution 11 came up as the special order of the day. According to the Daily Intelligencer, interested parties filled the capital in anticipation of another round of debates. Unfortunately for the spectators, the senators moved quickly to vote on the measure. Some legislators preceded their votes with comments of various lengths while others simply said "aye" or "no." Ultimately, the submission of a state prohibition amendment failed for the third time in as many years as fifteen senators voted yes and eleven senators voted no, three short of the required eighteen ayes. ${ }^{57}$ The state's most influential papers wasted little time weighing in on the political consequences of the amendment's rejection. The Register, which claimed that opposition to the resolution grew as the vote neared, reassured its readers that state prohibition "was defeated by a temperance Legislature; by men who are exceptionally temperate in their habits; who both practice and preach temperance, and a majority of whom are sincere advocates of temperance reform." These legislators defeated the bill, according to the organ, because citizens of individual counties already had the right to impose prohibition if they wished, and an amendment was unnecessary because the Constitution already allowed lawmakers to regulate the liquor industry. The Democratic journalists also insisted that many of the legislators who voted for the measure actually disliked the idea of state prohibition but either felt obligated to their constituents' wishes or feared the political repercussions of ignoring their dry petitions. ${ }^{58}$

I.H. Johnson made it clear that he wanted those lawmakers who ignored the wishes of their dry constituents during the 1883 session to fear the political repercussions of their decision. The February 14 edition of the West Virginia Freeman contained a large banner on the top of the

\footnotetext{
${ }^{57}$ Wheeling Daily Intelligencer, February 8, 1883 and West Virginia Journal and Bills of the Senate, 1883 (Wheeling, WV: Public Printing, 1883), 131-132.

${ }^{58}$ Wheeling Register, February 8, 1883.
} 
editorial page entitled "Voice of the People Strangled," which contained the names of the delegates and senators who had voted for submission of the amendment. Later editions, including those in the election year of 1884 , ran the same banner on the front page with a list of anti-referendum lawmakers. A subtitle read, "Here they are again! These are the very fellows that did it! Watch 'em!" "59 Johnson also commented on the role of party affiliation in the amendment's ultimate fate. While the dry editor again reminded his readers that prohibition was "not a party question," he lauded Greenback and Republican legislators, who voted almost solidly in favor of prohibition. He also credited the Democratic members who voted for submission. However, he fired a loud political warning shot across the bow of wet Democrats: "If Democrats, by their refusal to trust the people of the State, have put into the hands of their opponents a club that may fall heavily upon their own heads, they will have nobody but themselves to blame." Clearly, the most aggressive elements of the dry movement were ready to strike at any politician, regardless of affiliation, who rejected their cause. ${ }^{60}$ In his February 28 edition, Johnson also blamed specific conditions in and around the Wheeling Capital for the eventual defeat of state prohibition. According to the editor, the fact that the state capital was located in the brewing center of West Virginia made it difficult for dry politicians to rally support. In addition, Democratic Party bosses decided to work against the amendment because they believed that submission of state prohibition would harm their party and Governor Jackson himself did not favor submission. ${ }^{61}$

\footnotetext{
${ }^{59}$ West Virginia Freeman, February 14, 1883, and June 4, 1884.

${ }^{60}$ West Virginia Freeman, February 14, 1883; Johnson calls for the State Temperance Convention to set up a better temperance organizational structure at their annual meeting in order to prevent another prohibition failure in the Legislature in another editorial article on the 14.

${ }^{61}$ West Virginia Freeman, February 28, 1883; the author was not able to find any remarks made by Jackson on the issue of state prohibition in his addresses.
} 
The Daily Intelligencer, which apparently wished to make political hay out of the failure of state prohibition, accused the Democratic Party of legislative manipulation when it asserted that Mountain State Democrats, who ran both chambers, purposely designed the measure to pass the house and fail in the senate so "that the party record on prohibition might be split." Pointing out that every Republican in both houses (save one in each chamber) voted for submission and adopting the dry contention that a vote for submission was not necessarily a vote in favor of prohibition, the Republican organ warned that West Virginians "will resent the unwillingness of the Democratic Party to let them speak their will. A party which is afraid of the people has reason to stand in dread of them." ${ }^{, 62}$ The one senate Republican who stood against the submission of Resolution 11 was influential industrialist Nathan Scott. Scott, "a Wheeling glass manufacturer, banker, and mining magnate," was on his way to becoming one of "West Virginia's richest and most powerful men." ${ }^{\prime 63}$ In spite of his membership in the legislature's minority party, Scott made a powerful case against the imposition of state prohibition in a statement issued before he cast his no vote on the seventh. The magnate, who maintained that his vote was his alone as his constituents elected him to serve them as Senator, shared his experiences with state prohibition in other parts of the country. He argued that states with license laws were the most temperate while those with prohibition placed "the liquor traffic in the hands of irresponsible persons, and as a result you find drunkenness on every hand." Additionally, according to Scott, state prohibition threatened immigration-related population gains. He even admitted that his glass factory produced glassware for Kansas saloons identified as "John Walruff”s Stomach Invigorator," which proprietors filled with the Invigorator (beer)

\footnotetext{
${ }^{62}$ Wheeling Daily Intelligencer, February 8, 1883.

${ }^{63}$ John Alexander Williams, West Virginia and the Captains of Industry (Morgantown: West Virginia University Library, 1976), 3.
} 
when ordered. In short, Senator Scott stated that he would not support a form of prohibition "that if adopted will not only drive capital out of the State but will retard our development and result in an increase of taxation." ${ }^{64}$

The importance of Nathan Scott's decision to stand as the only Republican voice against state prohibition in the senate extends beyond its novelty. The industrialist's decision also illuminates an important aspect of the prohibition debate as the turn of the century approached. In the same way that one did not necessarily support prohibition simply because he or she was a Methodist, a Baptist, or lived in a rural county, one was not obligated to back antiliquor legislation because he or she was a member of the Republican Party. In the eyes of Scott, the voting trends of his party were far less important than the fact that a prohibitory law had the potential of putting his glass factory out of business and economically endangering his home district. There is even evidence to suggest that the Wheeling magnate feared constitutional prohibition. When prohibition reappeared in the 1887 senate session, Scott, who "drifted in and out of the session, failing to vote on over one-third of the roll calls," made sure to vote against it. ${ }^{65}$ While West Virginia Republicans usually voted for state prohibition more frequently than their Bourbon Democratic competitors, they were no more obliged to do so.

I.H. Johnson expressed his disappointment in the Mountain State Democratic Party's reluctance to add a pro-submission plank to their party platform during their 1884 convention in Wheeling. The Freeman's editor again claimed that his paper “[had] no interest in political parties as such." However, he admitted that prohibitionists had been "looking to that party for relief" since they had a vice grip on West Virginia political power. Much to his chagrin, the

\footnotetext{
${ }^{64}$ Wheeling Daily Intelligencer, February 8, 1883.

${ }^{65}$ Williams, West Virginia and the Captains of Industry, 81.
} 
party virtually ignored the pro-submission wing and expressed its opposition to any "sumptuary legislation."66 While it helped the dry cause that the vast majority of Republican delegates and senators usually favored at least the submission of a prohibition amendment to the people, their lack of a majority meant that antiliquor crusaders could not lean exclusively on the Grand Old Party. It also meant that activists could not target an audience based solely on their party affiliation. Consequently, dry workers like I.H. Johnson constantly had to beseech West Virginia voters "to lay all party feelings aside" and choose candidates based solely on their protemperance credentials, a difficult request to make in a state where party divisions were so stark and ingrained. ${ }^{67}$ It is important to note that the reticence of parties to adopt official positions on the liquor question continued into the twentieth century. West Virginia Presbyterians lamented this condition in their Report on the Standing Committee on Temperance at their first annual meeting in 1904: "We, as a Synod, from a strictly non-partisan point of view express our deep regret that the great political parties have not taken stronger ground upon this question so vital to American welfare." 68

As another legislative session dawned in 1885 , prohibitionists faced a situation similar to the one they had been grappling with for nearly a decade and a half. Democrats remained the majority in both chambers. ${ }^{69}$ Dry activists, who had recently realized that they could not count on the Democrat majority to assume any official party position on state prohibition, undoubtedly wondered what they could do to break through the senate stalemate and submit their resolution to

\footnotetext{
${ }^{66}$ West Virginia Freeman, July 30, 1884.

${ }^{67}$ West Virginia Freeman, October 1, 1884.

${ }^{68}$ Minutes of the First Annual Session of the Synod of West Virginia of the Presbyterian Church, Held at Parkersburg, West Virginia, October 18-20, 1904 (Morgantown, WV: Acme Publishing, 1904), 37.

${ }^{69}$ Legislature of West Virginia: Manual, 416 and 480.
} 
the people. The Executive Committee of the State Temperance Convention decided that the blunt force of volumes of signed petitions was a way to change the minds of the few lawmakers who stood between the drys and legislative victory. The Executive Committee provided blank copies of their pro-amendment petition to members of the County Temperance Committees in advance of the 1885 session. Copies of the petition, which the Freeman published in its November 12, 1884 issue, instructed the County Committees to "arrange them all in order, and send by mail or other convenient method to either of us, or to your representative at Wheeling [by January $\left.10^{\text {th }}, 1885\right]$." Not willing to rely on the willingness of the County Committee members, Dave Johnson and the Executive Committee also sent blank copies to local canvassers throughout West Virginia with a request "to canvass your neighborhood and get the name of every voter [their emphasis] if possible, signed to this petition." Johnson's committee's efforts did not cease with the movement's true believers. The Temperance Convention made an attempt "to put one of these blanks into the hands of every Minister in the State, every Post Master, and in all the county and village stores, as far as possible."70

This audacious organizational petition drive yielded impressive results as the 1885 legislature convened. The House of Delegates Journal index listed nearly three and a half pages of petitions signed by thousands of West Virginians. ${ }^{71}$ Unfortunately for the antiliquor agitators and their legislative allies, however, both the house resolution and its senate counterpart again failed to pass. House Joint Resolution Number Six received forty-one yes votes and twentythree no votes, short of the requisite two-thirds majority. The delegates subsequently left the

\footnotetext{
${ }^{70}$ Quoted in West Virginia Freeman, November 12, 1884.

${ }^{71}$ Journal of the House of Delegates of the State of West Virginia for the $18^{\text {th }}$ Session, 1885 (Wheeling, WV: Taney Printers, 1885), xxiii-xxvi.
} 
measure on the table on February $16 .^{72}$ A day after the failure of the house resolution, Senate Joint Resolution Number Seventeen emerged in the upper house. Senators read the bill for the first time and ordered it to its second reading on the twenty-fourth, but the measure ultimately progressed no further than that. ${ }^{73}$ State senators clearly ignored the pleas contained in a February 19 circular distributed by the State Temperance Executive Committee. Members of the Committee pleaded with members of the upper house to pass their resolution in order to induce the house to break their anti-resolution stalemate. The circular, of course, contained the default dry talking points, including attacks on the evils and social costs of the liquor trade, the difference between philosophically supporting prohibition and backing its submission to the people, pleas for bipartisanship, and the contention that a referendum on state prohibition was the desire of the majority of West Virginians (they claimed "nearly two-thirds"). ${ }^{74}$

As the newspaper coverage of yet another state prohibition disappointment suggested, some West Virginia legislators, especially Democrats, simply did not agree with these dry contentions. Enough lawmakers either believed that their job was to represent broadly, rather than automatically present, their constituents' wishes, saw prohibition as a party issue, or rejected the idea that most of their voters favored submission of an amendment to vote down on four separate occasions in one decade - a prohibition referendum. Jefferson County Democrat Delegate Lucas made the most forceful case for this opinion during the lower house's debates on their resolution. According to the Marshall Herald, "Mr. Lucas . . . said the

\footnotetext{
72 Journal of the House of Delegates, 1885, 48, 279-280; several newspapers reprinted in the Freeman stated that the bill was voted down 42-22, West Virginia Freeman, February 25, 1885.

${ }^{73}$ Journal of the Senate of the State of West Virginia for the $18^{\text {th }}$ Session, 1885 (Wheeling, WV: Taney Printers, 1885), 236 and 322-323.

${ }^{74}$ West Virginia Freeman, February 25, 1885.
} 
Democratic platform at Chicago declared against all sumptuary laws, and that the Republicans raised the question to create trouble in the Democratic Party, and that he hoped no Democrat would vote in favor of it." ${ }^{75}$ The Keyser Echo presented the Jefferson County delegate's words in even starker terms. Lucas, according to the eastern panhandle organ, argued "that to pass this resolution would be to sign the death warrant of the Democracy in this State., ${ }^{, 76}$ I.H. Johnson, faced with another defeat, stood by his repeated contention that anti-resolution legislators would pay for their votes. In the subtitle of his March 4 story on the measure's failure, Johnson commented that "the amendment lies on the table while the Legislature goes home for the people to elect a better one to do their will.," 77

Unfortunately for Mountain State prohibitionists, Johnson was as wrong as he was steadfast in his dry beliefs. In the pre-Progressive world of the late 1800s, anti-prohibition Democrats did not pay for their votes against a referendum - at least not enough to create the legislative turnover necessary to provide the pro-resolution faction the supermajority it needed. It is difficult to determine whether dry activists like Johnson actually believed that the majority of West Virginians favored a state prohibitory law, or even its submission to the voters, or whether their claims of widespread support were simply political bluster. It is quite possible, though, that the political, religious, and organizational leaders of the prohibition movement actually believed that most of their fellow citizens were dry. After all, these dry advocates associated with like-minded people on a fairly regular basis. The resulting political and social echo chamber could have easily created an overblown sense of antiliquor allegiance. The truth is

\footnotetext{
${ }^{75}$ Quoted in West Virginia Freeman, February 25, 1885.

${ }^{76}$ Quoted in West Virginia Freeman, February 25, 1885.

${ }^{77}$ West Virginia Freeman, March 4, 1885.
} 
that no one knew exactly where the great middle stood on prohibition precisely because the legislature had never authorized a popular vote on the issue. In the absence of hard data, politicians relied on their survival instincts to determine how far they could push for or against the great experiment. Ultimately, enough delegates and senators, especially Democrats, concluded that state prohibition was neither widely supported by their constituency nor important enough to their voters to cost them their seats. This allowed them to stonewall a statewide dry referendum. Dry leaders would finally understand how far away they were from their ultimate goal as the peak decade of the early prohibition movement in West Virginia neared its end. In a particularly cruel twist of political fate, Mountain State teetotalers would rapidly fall from the heights of legislative success in 1887 to the depths of electoral obliteration in 1888. Along the way, they would realize that their dry phalanx, while strengthening organizationally every day, was not yet a match for the armies mustered by West Virginia's liquor industry, their agents, and their allies. They would also be forced to admit that the vast majority of the Mountain State's citizens were not yet as progressive or dry as they had believed, or at least had hoped.

In the winter of 1887 , however, hope sprang eternal for prohibitionists as the House of Delegates passed that session's obligatory state prohibition resolution by an overwhelming majority of fifty-five to ten. ${ }^{78}$ Early indications suggested that an amendment would not enjoy the same level of support in the senate. According to the Morgantown New Dominion, "The Senate is not so unanimous. It is so equally divided for and against that it is a matter of doubt how it will be decided. The prospect seems to be against its passage."79 The Monongalia County organ proved prescient. As they had so many times before, the majority of senators

\footnotetext{
${ }^{78}$ West Virginia Journal and Bills of the House of Delegates, 1887 (Charleston, WV: Public Printing, 1887 ), 88.

${ }^{79}$ Morgantown New Dominion, February 5, 1887.
} 
voted for the bill (seventeen to seven), but not by enough to submit it to the people. ${ }^{80}$ I.H. Johnson and the Freeman refused to give up hope as the bill sat suspended in legislative purgatory after its initial defeat. Johnson hoped that the resolution would eventually pick up the votes necessary in another roll call to propel it on to the 1888 ballot. He claimed that one Democrat official commented "that if the Democratic Party allowed the Amendment to be defeated now again, it would never have another opportunity to receive petitions from the people, and Republicans would want their quarters after the next election." The editor also made mention of delegates hurrying through a "Prohibitory Law." According to Johnson, "This shows a remarkable growth in Prohibition sentiment, as reflected in the Delegates fresh from the people. $" 81$

What the house's decision to shift their efforts away from a constitutional measure to the passage of a statutory (legal) prohibition bill really indicated was that the dry faction of delegates had reached their breaking point. Yet another prohibitory amendment had passed the house only to be rejected by the senate. This time, instead of absorbing another maddeningly slim defeat, the prohibition movement's legislative allies temporarily jettisoned their goal of total constitutional prohibition in favor of some form of antiliquor legislation. The idea of a Mountain State legislature finally passing a statutory law banning alcohol, which they always had the power (and votes) to do, scared the wits out of West Virginia wets. ${ }^{82}$ The Wheeling Register, never a friend of any form of prohibition, commented that "no stone is left unturned by the radical Prohibitionist champions to foist a useless and injurious law upon this and some other

\footnotetext{
${ }^{80}$ Wheeling Register, February 6, 1887.

${ }^{81}$ West Virginia Freeman, February 9, 1887.

${ }^{82}$ Morgantown New Dominion, February 26, 1887.
} 
sections of the State" and reminded lawmakers that they were not obligated to approve statutory prohibition just because they promised their constituents that they would favor submission of an amendment. ${ }^{83}$ Even the Daily Intelligencer, the leading Republican daily in the state and a public supporter of submission, was dubious. Its editors opined that "the Intelligencer thought it a mistake to refuse the people an opportunity to express themselves on the question; and now another mistake is contemplated... There has been absolutely no expression of public sentiment to warrant the passage of a prohibitory act." ${ }^{\prime 84}$

Anti-amendment senators were just as concerned about the very real possibility of statutory prohibition. On February 17, 1887, just as the house-passed legal prohibitory bill neared its probable victory in the upper house, legislators called for another vote on the tabled constitutional amendment, three senators flipped their no votes at the last minute, and the resolution advanced on to the people by a twenty to six tally. Two of the three representatives who reversed their votes maintained that they did so because they preferred an amendment over a statutory bill as a referendum placed the issue in the hands of the people. ${ }^{85}$ Their real reason for performing such a sudden reversal was probably more cynical. As the New Dominion suggested, wet senators reversed course and authorized the referendum because they feared legal prohibition, knew they could delay "the evil day for at least two years longer," and hoped they could beat the drys in the 1888 referendum. ${ }^{86}$ Paradoxically, West Virginia wets and their allies had bought themselves time to fight prohibition in a statewide election by passing the resolution.

\footnotetext{
${ }^{83}$ Wheeling Register, February 17, 1887.

${ }^{84}$ Wheeling Daily Intelligencer, February 16, 1887.

${ }^{85}$ New York Times, February 18, 1887, and Wheeling Register, February 18, 1887.

${ }^{86}$ Morgantown New Dominion, February 26, 1887.
} 
They basically decided to gamble all their chips, hoping that they knew their constituents better than their prohibitionist allies.

The Mountain State wets' gamble ultimately paid off as West Virginians roundly rejected the prohibition amendment. Citizens in all but three counties voted against state prohibition and the measure lost by a margin of roughly 74,000 to $40,000 .{ }^{87}$ This resounding defeat was not the result of a lack of effort by antiliquor activists. Every existing dry-affiliated organization, party, and organ in the state rallied their support behind the measure. The WCTU, which had endorsed the Prohibition Party at their 1888 convention, joined forces with the third party in their electoral and pro-amendment efforts. According to historian James Henry Jacobs, "The combined pressure of these two temperance-minded groups made the proposed amendment ... the most important of the three submitted to the people in November." ${ }^{, 88}$ The biggest supporter of the proposed amendment was, of course, I.H. Johnson and the West Virginia Freeman. Johnson also endorsed the Prohibition Party, listing their ticket on the editorial page of his October 31 issue. ${ }^{89}$ Additionally, the dry leader turned his weekly into a prohibitionist campaign organ for most of the later part of 1888 as the election neared. Johnson provided free sample copies of the Freeman and published over 100,000 copies of a pro-amendment leaflet he titled "West Virginia Prohibition Amendment Catechism., ${ }^{90}$ The leaflet, offered to dry agitators in bulk and at less

\footnotetext{
${ }^{87}$ There are some conflicting numbers on the exact vote count and the exact number of counties voting down the referendum, but the Post-Chronicle possesses the most recent, and least biased numbers; Morgantown PostChronicle, November 6, 1912.

${ }^{88}$ James Henry Jacobs, "The West Virginia Gubernatorial Election Contest, 1888-1890," West Virginia History 7 (1946): 2. Accessed on www.wvculture.org (June 15, 2010).

${ }^{89}$ West Virginia Freeman, October 31, 1888.

${ }^{90}$ Johnson announced that he had printed 110,000 copies in his October 24 issue; West Virginia Freeman, October $24,1888$.
} 
than cost, contained four pages of prohibitionist talking points and responses to wet criticisms of state prohibition. ${ }^{91}$ In spite of this early version of direct-mail canvassing and the efforts of other prohibitionist organizations, the results of the referendum forced West Virginia drys back to square one.

Temperance activists rushed to explain their disastrous defeat at the hands of the average West Virginia citizen. Johnson, of course, used the loss to call for "more . . faithful work, especially in the Evangelistic Department." He also blamed the failure on the Devil: "It was a matter of momentous importance to Satan's kingdom, that the Prohibition Amendment should be defeated." The Devil (probably representing wet interests), according to Johnson, swayed or muzzled the traditional West Virginia press, scared voters and party officials away from the Prohibition Party, disseminated pro-liquor tracts from outside the Mountain State, and used the existing party machine infrastructure to distribute wet "blood money" at the polls. ${ }^{92}$ In reality, prohibition's failure had less to do with Lucifer and his earthly minions and more to do with the fact that, philosophically and politically, West Virginia was no different in 1888 than it had been in any of the other years the citizens, via their elected representatives, had rejected an amendment outlawing liquor. Democrats still dominated and would continue to dominate the legislature. According to historian Ken Fones-Wolf, “"'From 1872 to 1895, Democrats won 64 percent of the seats in the West Virginia House of Delegates and over 70 percent of the state senate seats." 93 Of course, the West Virginia Democratic Party was far from unified in the late nineteenth century. However, as Otis Rice and Stephen Brown maintain, "The overwhelmingly

\footnotetext{
${ }^{91}$ West Virginia Freeman, September 12, 1888.

92 West Virginia Freeman, November 14, 1888.

${ }^{93}$ Ken Fones-Wolf, Glass Towns: Industry, Labor, and Political Economy in Appalachia, 1890-1930s (Urbana: University of Illinois Press, 2007), 61.
} 
rural character of the state and party devotion to Jeffersonian principles of low taxes, economy in government, and states' rights provided the mortar of unity." Therefore, similar to the postReconstruction South described in Link's work, “during the Bourbon era state government rested lightly upon West Virginia citizens."94 The only difference was that prohibitionists successfully forced the hand of the West Virginia liquor industry during the 1887 legislature. In essence, while drys publically eviscerated lawmakers for ignoring the will of the citizenry during the 1880 s, the referendum returns indicated that the anti-submission senators and delegates had actually acted more democratically because they understood that the vast majority of West Virginia voters did not philosophically or politically favor a statewide prohibitory law.

Of the three counties that favored prohibition - Clay, Hancock, and Nicholas - none had a total population between 1883 and 1893 of more than 7,223. ${ }^{95}$ Additionally, given the relative pro-submission unanimity within the Mountain State GOP, it would be reasonable to assume that these three counties were Republican bulwarks from which prohibitionists could tap into the GOP's existing friendliness towards the movement and build a growing dry consensus in the early twentieth century. Unfortunately for antiliquor activists, it was not that simple as only one of the three, Hancock County, voted for James G. Blaine in the 1884 presidential election. In fact, of the nineteen West Virginia counties that favored Blaine, Hancock was the only one with Republican proclivities that opted for prohibition four years later. ${ }^{96}$ One aspect of the referendum vote that may appear incongruous is that, as I.H. Johnson pointed out, "three-

\footnotetext{
${ }^{94}$ Otis Rice and Stephen Brown, West Virginia: A History, $2^{\text {nd }}$ ed. (Lexington: University Press of Kentucky, 1993), 168.

${ }^{95}$ Stanley Parsons, et al, ed., US Congressional Districts and Data, 1883-1913 (New York: Greenwood Press, 1990), 159.

${ }^{96}$ Wheeling Daily Intelligencer, November 5, 1888.
} 
fourths" of the counties in West Virginia did not grant liquor licenses on the local level in 1888 while almost all of them voted against prohibition on the statewide level. Johnson claimed that this seemingly peculiar situation resulted from the fact that wet political favors and vote buying overwhelmed the "evangelistic" work of dry agitators at the polls. ${ }^{97}$ While there may be a sliver of truth to the editor's corruption charges and the rural, Democratic Party nature of late nineteenth-century West Virginia suppressed widespread support for state-level prohibition, another reason for this seemingly paradoxical situation was that many of the local judges who possessed the authority to issue or deny liquor licenses in their respective counties practiced an early form of judicial activism. In many counties, judges ignored the will of the majority of the people because, as was almost always the case in local elections, only the most committed voters participated. This minority constituency, which certainly included antiliquor activists, effectively dominated the majority that either had no qualms about or sided with the liquor trade. $^{98}$

At the end of the day, then, state prohibition's absolutely disastrous showing in the 1888 election shattered any dreams that the antiliquor movement may have had of either securing a majority favorable to prohibition or imposing their minority values on the rest of the state. The defeat was so total it appears that I.H. Johnson, after nearly a decade of spirited dry agitation, printed his final edition of the Freeman on December 19. ${ }^{99}$ The 1880s had been the heyday of prohibition amendment agitation in West Virginia. By the 1890s, however, legislative journals

\footnotetext{
${ }^{97}$ West Virginia Freeman, November 14, 1888.

${ }^{98}$ Historian Jack Blocker explores the ASL's imposition of the minority prohibition movement on an unwilling American electorate at the end of his Epilogue; Jack S. Blocker, Retreat from Reform: The Prohibition Movement in the Unites States, 1890-1913 (Westport, CT: Greenwood Press, 1976), 244.

${ }^{99}$ While Johnson makes no mention of the December 19 edition being his last, the Freeman collection abruptly ceases after that date.
} 
suggest that serious attempts at constitutional prohibition had basically come to a halt in the Mountain State. In the words of historian E. Kidd Lockard, "The [1888] vote served as a sort of breaker to the rising tide."100 This fatigue extended to the movement in much of the rest of the United States. According to Szymanski, "By 1890 the crusade for state and national prohibition was at a virtual standstill.,"101

It is important to note that, while organized efforts at statewide prohibition ground to a halt after 1888, temperance-minded religious and associational organizations did not abandon their work in West Virginia. Many organizations and conventions retained their temperance committees and continued to issue proclamations and resolutions, although there was a palpable loss of energy in the 1890s. In addition, citizens in the Mountain State and around the nation began to experience fundamental shifts in their political and social environment as the twentieth century neared. ${ }^{102}$ The temperance committee of the ME Conference shifted their prohibitionist goals from the statewide level back to the local areas a year after the defeat of the referendum. At their 1889 Conference, the Methodists announced that "where we cannot obtain State prohibition, we are in favor of local option, and will work through municipalities, districts and counties, up to State prohibition, and from this up to National Prohibition."103

Interestingly, this shift in ME temperance strategy occurred several years before the establishment of the ASL and its new strategy of "local gradualism." According to Szymanski,

\footnotetext{
${ }^{100}$ E. Kidd Lockard, “The Temperance Movement in West Virginia” (MA thesis, West Virginia University, 1937), 25.

${ }^{101}$ Szymanski, Pathways to Prohibition, 3.

${ }^{102}$ A more detailed description of these shifts will be provided in chapter four.

${ }^{103}$ Official Journal and Minutes of the $43^{r d}$ Annual Session of the West Virginia Conference of the Methodist Episcopal Church, Held at Point Pleasant, WV, September 18 to 23, 1889 (Wheeling: WV Printing Company, 1889), 56.
} 
there existed a "shift in the [dry] movement's strategy from promoting state constitutional amendments to advocating "local gradualism"' between the 1880s and the early twentieth century. This approach, as the author describes, allowed the ASL to recruit local antiliquor activists and broaden their scale of operations: "By attaining partial but positive victories in the legislative, electoral, and judicial arenas ... a proponent of municipal prohibition could [eventually] become an advocate ... of national constitutional prohibition." Additionally, as Szymanski points out, "Local gradualism is 'local' in that it initially focuses on local issues before targeting the state and national levels of government. It is 'gradualist' in that it emphasizes achieving moderate goals before pursuing more radical goals."104 West Virginia gained a state chapter of the ASL in 1896. For much of the rest of the 1890s, however, the Mountain State and national ASL remained non-factors in West Virginia's post-referendum dry movement. Timberlake argues that "the first three years of the Anti-Saloon League's existence was a period of severe hardship. Launched during an economic depression and at a time when temperance sentiment was at a low point, the league had to struggle to keep alive."105 While it emerged under less than ideal circumstances, the ASL eventually became one of the most successful and important parts of the post-1900 temperance movement in the Mountain State.

Before the founding of the West Virginia ASL and even prior to the failure of 1888, some dry activists and their political allies began attacking the liquor trade via their own version of political gradualism. Many prohibitionists favored a statewide constitutional ban on the liquor trade. Groups like the WCTU, however, added to this ultimate goal a series of laws designed to chip away at the wet fortress in West Virginia. In short, this approach could be identified as

\footnotetext{
${ }^{104}$ Szymanski, Pathways to Prohibition, 4-5.

105 James H. Timberlake, Prohibition and the Progressive Movement (Cambridge, MA: Harvard University Press, 1963), 129.
} 
statutory gradualism. For example, dry legislators, with support from the WCTU and the ME Church, passed a Scientific Instruction Law during the 1887 session. The law required "that the physiological effects of alcohol and narcotics upon the human system, shall be taught in all the public schools of the state."106 While certainly short of total state prohibition, this bill authorized the antiliquor inculcation of an entire generation of Mountain State children - young people who would grow up to be eligible voters in 1912. Lawmakers also authorized a bill amending and reenacting portions of a regulatory bill banning the sale of liquor "to any minor or person of unsound mind.",107

The efforts of West Virginia statutory gradualists continued into the first decade of the 1900s as lawmakers and their temperance allies passed numerous pieces of legislation regulating the liquor trade. While not all of them were successful, Mountain State drys were able to place increasingly difficult rules and proscriptions on saloon owners. As the West Virginia ASL became an increasingly important part of the antiliquor movement after the turn of the century, it began backing some of these laws. In fact, the ASL was the key factor in securing better enforcement of Sunday closing laws in $1908 .{ }^{108}$ By the end of the nineteenth century, dry agitators had put away their constitutional prohibition machetes and decided to excise the liquor trade in West Virginia with a scalpel. Every gradualist law placed on the books made running an alcohol-related business that much more difficult. Constant changes in the regulatory

\footnotetext{
${ }^{106}$ Minutes of the $41^{\text {st }}$ Annual Session of the West Virginia Conference of the Methodist Episcopal Church, Held at Parkersburg, WV, October 5-11, 1887 (Morgantown, WV: New Dominion Steam Printing House, 1887), 46; Annual Reports of the WCTU of West Virginia, 1886-1888 (Keyser, WV: Mountain Echo Printers, 1888), 51.

${ }^{107}$ Acts of the Legislature of West Virginia at its $20^{\text {th }}$ Regular Session (Charleston, WV: Donnelly Public Printers, 1891), 331.

${ }^{108}$ Wheeling Register, March 5, 1908.
} 
environment forced the wet industry to cede ground and made the liquor business an increasingly high-risk industry.

As Mountain State wets became more and more vulnerable and defensive, West Virginia prohibitionists became increasingly bolder until they were finally ready to go after the big prize again - and win - in 1912. New strategies and new organizations like the ASL helped. However, the roots of victory in 1912 can be traced to the demographic changes and anxieties that emerged around the turn of the century and the shift from Gilded Age to Progressive politics. Most importantly, victory would have been impossible if not for the organizational efforts, agitation, legislative failures, and steadfastness that nourished, taught, punished, and ultimately kept alive the nineteenth century movement - even in the midst of waning support and interest in the 1890s. The durability learned in the repeated failures of the 1880 s would serve antiliquor elements well in the twentieth century as a dry victory was far from a foregone conclusion. West Virginia's liquor industry, while under limited attack from statutory gradualist legislation, was not nearly ready to abandon its lucrative trade. After all, it had been victorious in the first largescale battle in the war for prohibition in the Mountain State in 1888, and it stood ready to meet prohibitionist agitation with its own campaign. The saloon war had only just begun. 
CHAPTER FOUR: Drying the Mountains: Sociopolitical Change, the Anti-Saloon League Ascendancy, and the Triumph of State Prohibition, 1890s-1912

Every man in West Virginia who votes against Ratification of the Amendment deserves to have his boy die a drunkard, and his daughter to live in the arms of a rum-soaked wretch during the remainder of her life. ${ }^{1}$

The Anti-Saloon League (ASL), conceived in Ohio in 1893 and later nationally organized in Washington, DC in 1895, stood for only one cause: "The extermination of the beverage liquor traffic." This laser-like focus on one issue allowed the organization to eschew party affiliations and remain above the late nineteenth and early twentieth-century partisan fray. According to the ASL, "The league pledges itself to avoid affiliation with any political party . . . and to maintain an attitude of strict neutrality on all questions of public policy not directly and immediately concerned with the traffic in strong drink." ${ }^{2}$ Temperance and prohibition historiography grants the ASL a significant role in the ultimate success of national prohibition. After all, as Szymanski maintains, most attempts at state prohibition (including in West Virginia) were unsuccessful in the 1880 s and "by 1890 the crusade for state and national prohibition was at a virtual standstill." In essence, then, the ASL appears to have emerged at precisely the right time for a radical reform

\footnotetext{
${ }^{1}$ Billy Sunday, quoted in E. Kidd Lockard, "The Temperance Movement in West Virginia" (MA thesis, West Virginia University, 1937), 38-39.

2 Quoted in Deets Pickett, ed., The Cyclopedia of Temperance, Prohibition and Public Morals (New York: Methodist Book Concern, 1917), 29.

${ }^{3}$ Ann-Marie Szymanksi, Pathways to Prohibition: Radicals, Moderates, and Social Movement Outcomes (Durham, NC: Duke University Press, 2003), 3.
} 
movement that was in the process of losing what political and social momentum it had enjoyed earlier in the nineteenth century.

While the development and operation of the ASL was indeed a major factor in the passage of state and federal prohibition laws, it was far from the only one. The mere existence of yet another prohibitionist organization in the Mountain State, no matter how well-organized and politically shrewd, is not sufficient to explain satisfactorily the seismic shift in measurable sentiment from general opposition to a state prohibition law in 1888 to majority support for a dry regime in 1912. It is important to remember that, aside from some incremental statutory adjustments, dry elements and their political allies rarely, if ever, experienced major victories in the legislature before the turn of the twentieth century. Even when Mountain State prohibitionists were successful in submitting a prohibition referendum to the people during the 1887 legislative session, a large percentage of West Virginians rejected state prohibition in the subsequent 1888 election by a vote of approximately 74,000 to 40,000. ${ }^{4}$ This statewide rejection signified one of the dry movement's lowest points in West Virginia. However, less than a quarter of a century later, these same activists experienced ultimate victory as public sentiment quite literally flipped and Mountain State citizens decided to mount the water wagon by voting for state prohibition 164,945 to 72,603 in the 1912 general election. ${ }^{5}$

Clearly, something had changed the minds of the Mountain State's great moderate majority, the citizens who owed no particular allegiance to the wet or dry cause, but who nonetheless held the key to shaping social policy in their state. The key to understanding such a seismic shift in public opinion, then, is not to focus solely on the true believers. West Virginia's

\footnotetext{
${ }^{4}$ Morgantown Post-Chronicle, November 6, 1912.

${ }^{5}$ John T. Harris, ed., West Virginia Legislative Hand Book and Manual and Official Register, 1916 (rev) (Charleston, WV: Tribune Printing, 1916), 722.
} 
wet and dry activists may have been the most personally invested and thus may have dominated the public discourse on prohibition policy, but their votes did not decide the 1888 or 1912 referendum on state prohibition. Electorally, the rapid swing over twenty-four years from an almost two-to-one wet majority to an over two-to-one dry victory can be explained by a shift in public opinion among undecided voters. The development of better organization, new strategies, and fresh associational blood welded the teetotalers into a far more formidable political and activist weapon in 1912 than it was in 1881. This organizational and strategic improvement was probably the single most important reason for the dry movement's victory in 1912. Large numbers of undecided voters - and their children - undoubtedly entered the dry camp between 1881 and 1912 because of the prohibition movement's more persistent and polished propaganda.

Better coordinated and organized messaging cannot, however, account for a complete flip-flop in public sentiment in just over thirty years - less than twenty-five if it is measured from referendum to referendum. In order to account satisfactorily for this momentous shift, it is necessary to investigate additionally the social changes occurring both within and without the borders of the Mountain State between the late nineteenth and early twentieth centuries. Blocker sheds some light on these transformations and their impact on the dry cause in his work on the national prohibition movement:

Between 1890 and 1913 the prohibition movement underwent a fundamental change, a change which reveals a great deal about what it meant to be a middle-class American in the nineteenth century and what it [meant] to be a middle-class American in the twentieth. Superficially, the change was merely a shift from a failed institution, the Prohibition party, to a new organization, the Anti-Saloon League, which promised and delivered tangible results. But this shift is only a key to the real change, a 
transformation of social outlook so profound that it can be understood only in the context of a cataclysmic era - the 1890 s. $^{6}$

The profound shift in social outlook to which Blocker refers is the migration from the Gilded Age politics and society of the late nineteenth century to the Progressive Era of the early twentieth century. Of course, the social upheaval and economic panic of the cataclysmic 1890s reached every corner of the United States - including West Virginia - and helped spur the development of the Progressive Movement, which emerged around 1900. Reacting to these unsettling social changes and economic dislocations, growing numbers of Americans became increasingly willing to bring order to the chaos. ${ }^{7}$

Using political pressure and governmental regulation to dull the devastating effects of America's turn-of-the-century growing pains, and in the case of the prohibition movement, to control the behavior of their fellow Americans became a more acceptable and increasingly popular goal for some Americans as the twentieth century dawned. Suddenly, the idea of telling a citizen whether or not he or she had the right to imbibe was well within the realm of social and political reason. When early dry organizations like the WCTU and Prohibition Party and their evangelical allies emerged during the Gilded Age, they were political and social outliers - protoprogressives trying to operate in a pre-progressive age. When the ASL emerged as a reform organization in the 1890s, however, it was part of the general growth and increasing popularity of associational groups that specialized in one progressive cause or another. As K. Austin Kerr argues, "The Anti-Saloon League fit within this context of expanding and specializing

\footnotetext{
${ }^{6}$ Jack S. Blocker, Retreat from Reform: The Prohibition Movement in the Unites States, 1890-1913 (Westport, CT: Greenwood Press, 1976), 6.

${ }^{7}$ George Brown Tindall and David Emory Shi, America: $A$ Narrative History, $7^{\text {th }}$ ed., vol.2 (New York: WW Norton and Company, 2007), 890.
} 
associational activity." ${ }^{8}$ In short, as the Progressive Era emerged around the turn of the century, temperance advocates and prohibitionist agitators and their accompanying groups were no longer outsiders; they were now part of a larger, more mainstream socially and politically progressive club.

Coupled with this emergence of a Progressive social outlook was the rise of the Republican Party in the Mountain State. As discussed in the third chapter, West Virginia Democrats enjoyed a virtual monopoly on the state legislature after 1872 and, operating as true Bourbons, exercised as little governmental influence on Mountain State citizens as possible. This Bourbon outlook extended to the governor's mansion as six straight Democratic governors served between 1871 and $1897 .{ }^{9}$ This Democratic domination would not, however, be able to withstand the rise of an industrial economy around the turn of the twentieth century. Rice and Brown argue that "West Virginians were ready by 1896 to entrust the future of the state to the Republicans, whose principles and policies were already identified with the industrial and business growth of the nation." ${ }^{\prime 10}$ Starting with the election of 1896, the GOP dominated the executive branch until the reemergence of the Democrats after the 1932 election. Eight of the nine chief executives in Charleston between 1896 and 1932 were Republicans. While Mountain State Democrats and Republicans experienced more parity in the legislature after the turn of the century, the GOP enjoyed significantly more legislative power than it had before. ${ }^{11}$

\footnotetext{
${ }^{8}$ K. Austin Kerr, Organized for Prohibition: A New History of the Anti-Saloon League (New Haven, CT: Yale University Press, 1985), 5.

${ }^{9}$ JC Dillon, ed., West Virginia Blue Book, 1976 (Charleston, WV: Jarrett Printing, 1976), 239.

${ }^{10}$ Otis Rice and Stephen Brown, West Virginia: A History, $2^{\text {nd }}$ ed. (Lexington: University Press of Kentucky, 1993), 173.

${ }^{11}$ Dillon, West Virginia Blue Book, 1976, 239 and 321.
} 
It is important to emphasize, however, that the development of relative Republican political domination around and after the turn of the century did not necessarily guarantee prohibitionist success in West Virginia. As the Nathan Scott case demonstrated in chapter three, being a Republican did not necessarily mean that one was dry. In fact, it would be several years before a Republican governor - or the party itself for that matter - publically enunciated a strictly prohibitionist position. Instead of an unconditional victory for Mountain State drys, the rise of the West Virginia GOP was more a case of addition by subtraction. The victory of more industrially oriented Republicans meant that small-government Bourbon Democrats no longer determined the agenda in Charleston. The rise of industrialization and the GOP basically wiped clean the political slate for West Virginia prohibitionists. It has become a truism in West Virginia history that there existed little functional difference between pro-industrial Democratic and Republican politicians after the turn of the century. Williams argues that the political and economic developments of the 1880s and 1890s "led to the consolidation of power in both political parties by 1900, a state of affairs that was aptly described as a bipartisan 'merger' operated by and for the leading business interests in the state."12 Historian Carletta Bush concurs with this assessment in her unpublished article on the revival of religious activism in and around Fairmont. She argues that "coal operators such as the Watsons [whose patriarch - James Watson - is credited with being West Virginia's father of the coal industry] dominated the political machinery in West Virginia and owned both the Republican and Democratic parties in the state. Many of these operators were proponents of prohibition."13 While certainly not assured of

\footnotetext{
12 John Alexander Williams, West Virginia and the Captains of Industry (Morgantown: West Virginia University Library, 1976), 15.

${ }^{13}$ Carletta H. Bush, unpublished article, "Religious Fervor in the Fairmont, WV Field: Calls for Revival in the Coal City, 1908-1919." accessed on www.are.as.wvu.edu/cbush.htm (September 2, 2008).
} 
victory by this political and philosophical shift in the halls of the Capital and governor's mansion, Mountain State teetotalers would now be granted a fighting chance to push their prohibitionist agenda.

Turn-of-the-century citizens also experienced a fundamental and nationwide shift in the political philosophy of the United States as many of society's most influential actors eschewed the laissez-faire style of the Gilded Age and embraced the more activist orientation of the Progressive Era. This transformational change only aided the movement against liquor as legal proscriptions against social ills were not only acceptable, but popular political goals. When West Virginians entered their polling places at the height of the Progressive Era in 1912, they were much more likely to accept the concept of improving humankind through regulatory action than they were in the midst of the Gilded Age in 1888. Of course, Mountain State citizens, like any other populace, did not join the Progressive movement simply because it became an increasingly dominant political worldview. As the twentieth century dawned, West Virginians faced fundamental changes in their state's demographic and socioeconomic environment. In short, the Mountain State was a far more populous, industrial, and ethnically and racially diverse place in 1912 than it had been in 1888. The total population of West Virginia in 1880 was 618,457 . By 1920 , it was $1,463,701 .^{14}$

The key reason for this sharp spike in population growth was the development of the Mountain State's industrial and resource extraction industries. It is important to note that there already existed a manufacturing industry centered in and around Wheeling and the rest of the Northern Panhandle. As Ken Fones-Wolf indicates, "These [Ohio River] counties traced their industrial traditions back to Antebellum times, and remained committed to industry and

\footnotetext{
${ }^{14}$ Frank S. Riddel, The Historical Atlas of West Virginia (Morgantown, WV: West Virginia University Press, 2008), 220, 228.
} 
commerce."15 The rest of the state did not share the northern Ohio Valley's commitment to industrial development. The vast majority of West Virginians remained farmers in $1880 .{ }^{16}$ During the last decade of the nineteenth century and early twentieth century, however, the Mountain State economy would become increasingly tied to an industrial and extractive economy. Spurred on by the "development faith" and a newly empowered, pro-development state Republican Party, industrialization exploded in West Virginia. ${ }^{17}$ With this explosion of industry came an accompanying explosion in population. In the midst of the 1890 s economic chaos, West Virginia's population still grew "by nearly 46 percent." Most of the growth in the late 1800s and early 1900s happened in the industrial Ohio River Valley and north-central and southern coalfields. ${ }^{18}$ This massive influx of new citizens fundamentally changed the economic base of the Mountain State. Industrial occupations were soon more numerous than farming jobs. According to Fones-Wolf, "By 1910, the combined numbers of men in manufacturing and resource extraction topped the numbers in agriculture." 19

This shift from an agriculturally-based economy to an industrial one and subsequent upturn in population can help explain the increased popularity and eventual victory of state prohibition. These macroeconomic and demographic changes did, in the eyes of some native West Virginians, pose significant threats to the white, Anglo-Saxon, Protestant social order. It was not so much that new people were settling in the Mountain State. It was that these new

\footnotetext{
${ }^{15}$ Ken Fones-Wolf, Glass Towns: Industry, Labor, and Political Economy in Appalachia, 1890-1930s (Urbana: University of Illinois Press, 2007), 62.

${ }^{16}$ Fones-Wolf puts the number at "more than two-thirds"; Fones-Wolf, Glass Towns, 62.

${ }^{17}$ For more information on the "development faith" and the 1890s victory of the Republican Party, see chapter three of Glass Towns.

${ }^{18}$ Fones-Wolf, Glass Towns, 69-70.

${ }^{19}$ Fones-Wolf, Glass Towns, 70.
} 
people looked, spoke, and worshipped differently. Massive numbers of European immigrants and African-American migrants from the South arrived in West Virginia throughout the last decade of the nineteenth and first two decades of the twentieth centuries to work in the manufacturing and mining industries. It is important to note that portions of the Mountain State had already experienced immigration. Ohio County and Wheeling hosted a population that was nearly 21 percent foreign born as early as the 1870s and 80s. Of course, Ohio County was an urban center - its population density of almost 270 persons per mile was by far the most densely populated county in the state - and it had traditionally been a manufacturing hub. ${ }^{20}$ Other parts of the state, however, had never experienced massive population spikes and foreign and AfricanAmerican immigration before the rise of industry. As historian Deborah Weiner notes, “Between 1880 and 1920, southern West Virginia's coal counties grew from forty thousand to more than three hundred thousand inhabitants." ${ }^{21}$ The vast majority of these new residents came from the American South and southern and eastern Europe. In a matter of a few decades, southern West Virginia counties went from a nearly all-native white society to "an entirely new civilization ... one of startling multicultural diversity." According to Weiner, "By 1908 the mining workforce was 41 percent native white, 31 percent black, and 28 percent foreign born." ${ }^{, 22}$ While these changes did not occur with the same intensity all over the state as in the southern coalfields, nearly all West Virginians felt the economic and social ground shift at the beginning of the twentieth century. According to analytical reports drawn from the 1910 United States Census, European foreign-born whites comprised 4.5 percent of the state's total

\footnotetext{
${ }^{20}$ Stanley B. Parson et al, ed., United States Congressional Districts and Data, 1843-1883 (New York: Greenwood Press, 1986), 224.

${ }^{21}$ Deborah R. Weiner, Coalfield Jews: An Appalachian History (Urbana: University of Illinois Press, 2006), 23.

${ }^{22}$ Weiner, Coalfield Jews, 23.
} 
population. Of that 4.5 percent total, over three-quarters hailed from southern and eastern European countries. ${ }^{23}$ The majority of these new West Virginians were, of course, Catholics. In the eyes of the existing Mountain State citizenry, these new Catholic immigrants brought different - and potentially dangerous - attitudes towards alcohol with them. While historian James H. Timberlake acknowledges that some elements within the Catholic Church worked for alcohol proscription, he maintains that "most Roman Catholics, however, opposed prohibition." By the turn of the century, denominational battle lines had been drawn on the liquor question. According to Timberlake, "The American religious community ... was divided over prohibition. On the one side were most Protestants led by the Presbyterian, Methodist, Baptist, and Congregational Churches; on the other side were most Roman Catholics and Jews." ${ }^{24}$

Catholics were not new to the Mountain State. In fact, Catholicism was the secondlargest single denomination - as measured in the Census by "sittings" - in 1870 West Virginia. ${ }^{25}$ Catholic West Virginians were, however, segregated in the relatively urbanized Northern Panhandle before industrialization. Ohio County, which encompassed the manufacturing center of Wheeling, was home to a 15 percent Catholic population between 1883 and 1893 . No other West Virginia county hosted a Catholic population of more than 4.3 percent at that time. ${ }^{26}$ The new wave of eastern and southern European immigration that accompanied the industrialization

\footnotetext{
${ }^{23} 13^{\text {th }}$ Census of the United States, Taken in 1910, Volume I, Population, General Report and Analysis (Washington: Government Printing Office, 1913), 816.

${ }^{24}$ James H. Timberlake, Prohibition and the Progressive Movement (Cambridge, MA: Harvard University Press, 1963), 32-33.

${ }^{25}$ There were 104,000 Catholic sittings, according to the 1870 Census; Francis Walker, ed., A Compendium of the $9^{\text {th }}$ Census of the United States, June $1^{\text {st }}, 1870$ (Washington: Government Printing Office, 1872), 523.

${ }^{26}$ Mineral County had a Catholic population of 4.3 percent; Stanley B. Parson et al, ed., United States Congressional Districts and Data, 1883-1913 (New York: Greenwood Press, 1990), 159.
} 
of West Virginia's economy before and after the turn of the twentieth century spread the customs and political influence of Roman Catholicism beyond the Northern Panhandle. Gradually, Mountain State Protestants who may have previously ignored the admonitions of their preachers against the dangers of the saloon and the socially deleterious influence of Catholic workers in Wheeling because of distance were now listening as saloons and Catholics arrived on their doorsteps.

This change created significant anxiety in portions of the Mountain State that had never hosted a diverse populace. While the stark demographic shift in the southern coalfield counties has already been mentioned, the northern coalfields of North-Central West Virginia also experienced an influx of working-class Catholic immigrants. Harrison County - home to Clarksburg and a functioning manufacturing industry by the turn of the century - was only a little over 1 percent Catholic between 1883 and 1893. By between 1903 and 1913, it was almost 8 percent Catholic. ${ }^{27}$ In the case of Harrison County and Clarksburg, the anxieties of the area's majority native population may have been well-founded. According to Fones-Wolf, as previously mentioned in chapter one, "The influx of new voters helped repeal the prohibition ordinance and led to thirty-five new liquor licenses in 1905 alone. ${ }^{28}$ This inter-ethnic tension even boiled over into violence in Fairmont a year after the imposition of the Yost Law. According to historian Ron Lewis, "Ethnic tensions plummeted to a new low with the passage of prohibition legislation." Prohibition, mixed with "other grievances," caused southern and eastern European coal miners to strike in 1915 and murder a local lawman named William Riggs, who had been in charge of a group of strikebreakers. The immigrant strikers "singled out Constable

\footnotetext{
${ }^{27}$ Parsons, US Congressional Districts and Data, 1883-1913, 159, 299.

${ }^{28}$ Fones-Wolf, Glass Towns, 126.
} 
Riggs because he enforced the Yost Law, and he subsequently died from the brutal treatment he received.",29

As the ultimate success of state prohibition indicates, large numbers of native Protestant West Virginians began responding to perceived, and, in some cases, real threats to their established social values and priorities - including those regarding strong drink - by supporting causes like the prohibition movement around the turn of the century. According to Bush, "As America rushed to industrialize in the last two decades of the nineteenth century, prohibition emerged as a national issue as many Protestant Americans touted it as the solution to many of the nation's ills."30 Jack Blocker's assessment of the American middle-classes' relationship with prohibition could also easily be applied to the Mountain State native Protestant population. He argues that "prohibition in the late nineteenth century functioned as a political device to create a middle-class cultural consensus, to protect it from penetration by competing norms of behavior." 31 Paradoxically, then, the very social and cultural upheavals that frightened majority West Virginians would end up nourishing the prohibition movement as the Mountain State moved into the twentieth century.

There is no single analytical silver bullet to explain the seemingly implausible shift in public sentiment from wet to dry between the referenda of 1888 and 1912 . While new and better prohibitionist organization, funding, and strategies were the most important developments that eventually led to the victory of state prohibition in 1912, these changes did not occur in a social

\footnotetext{
${ }^{29}$ Ronald L. Lewis, "Americanizing Immigrant Coal Miners in Northern West Virginia: Monongalia County between the World Wars," in Transnational West Virginia: Ethnic Communities and Economic Change, 1840-1940, eds. Ken Fones-Wolf and Ronald L. Lewis (Morgantown: West Virginia University Press, 2002), 275-276.

${ }^{30}$ Bush, "Religious Fervor in the Fairmont, WV Field."

${ }^{31}$ Blocker, Retreat from Reform, 14.
} 
or political vacuum. Early twentieth century America was simply a different place than it was in the late 1800s. The rise of the Progressive Movement made ideas like prohibition more palatable to a great electoral middle that, prior to Progressivism, neither thought nor really cared about the behavior of other citizens. Arriving at roughly the same time that Americans - West Virginians included - began to believe in the principle of bettering one's fellow citizens through sociopolitical control were groups of new citizens who, in the eyes of anxious Mountain State natives, needed such regulation. What occurred in West Virginia in the late nineteenth and early twentieth century was a perfect storm of more effective and efficient political activism, the decline of laissez-faire Bourbon democracy and the subsequent rise of a pro-industrial political philosophy, nationally significant shifts in ideas about the role of government in the lives of citizens, and socially disruptive demographic changes unleashed by the rise of industrialization in the Mountain State. These four simultaneous and oftentimes complementary transformations worked together to convince the majority of West Virginians that state prohibition was a valid, necessary, and even noble experiment.

Of course, three of these four changes were contextual and environmental in nature. They undoubtedly set the stage for the ultimate triumph of statewide prohibition, but they did not act out the play. It took more tangible, functional, and ultimately gradual changes to the organic law of West Virginia to activate the political and philosophical transitions occurring in and around the Mountain State. Even the primary transformation - the improvement of political activism - did not emerge until well into the first decade of the 1900s. The impetus for the organizational and structural refinement of the dry movement in the Mountain State was the increasing influence of the ASL's West Virginia chapter. While the West Virginia ASL emerged several years before the end of the nineteenth century in 1896, even its former leaders admitted 
that "the league organization ... was not very effective until Reverend T.M. Hare became superintendent thirteen years later."32 Consequently, what was left of the dry movement after its devastating defeat in the 1888 constitutional referendum on state prohibition limped along through the rest of the 1800 s and into the first decade of the 1900s without a unifying structural basis. This lack of coordination showed in the relative absence of legislative action on the issue of liquor proscription around the turn of the century. According to Lockard, "The legislatures meeting after 1887 had not been disposed to pass many acts dealing with intoxicating beverages." 33

Lockard is fairly accurate in his estimate. There were very few liquor elimination-related bills passed between 1887 and 1903 in Charleston. In spite of the relative lack of dry action in the legislature, however, it is important not to ignore completely the decade and a half spent by West Virginia drys in political exile. After all, their 1888 defeat did not compel groups like the WCTU to fold up shop. Evangelical Protestant sects like the Methodists and Baptists maintained temperance committees which still offered temperance reports and resolutions at most of their annual meetings. Additionally, local Protestant preachers still "fought the good fight" and actively resisted the license system in their neighborhoods. One pastor from the Fairmont area boasted that his church hosted a five day and five night revival in 1896 " just before the municipal election, when by an overwhelming majority the 'License ticket' was defeated. Fairview will be 'dry' after April 30 for the first time in its history." 34

\footnotetext{
${ }^{32}$ Lockard, "The Temperance Movement," 26. Lockard received this input from a personal letter he received from former Superintendent of the West Virginia ASL, G.W. Crabbe.

${ }^{33}$ Lockard, "The Temperance Movement," 26.

${ }^{34}$ Methodist Episcopal Advocate, May 13, 1896.
} 
When West Virginia's evangelical Protestant leaders and lay people congregated for their annual meetings around the turn of the century, the prohibitionist fire that had burned so brightly in the middle and latter parts of the nineteenth century had begun to die down. The Baptist General Association's 1889 report on temperance, issued almost exactly a year after the defeat of the prohibition referendum, assumed a disappointed - if not openly frustrated - tone. In explaining the amendment's defeat, the authors blamed distractions caused by national and state issues in the midst of a general election, the liquor industry's organized and fraudulent electoral strategies, a lack of support from important state newspapers, "the indifference, and sometimes open opposition of Christians and Christian ministers," and a "lack of harmonious and thoroughly organized effort upon the part of temperance people themselves." Temperance committee members then laid out a plan of action instructing its members to, among other things, oppose "the compromise policy of high license ... teach unequivocally [their emphasis], in our homes, from our pulpits, in our Sunday Schools, and through the columns of the religious press, the principle of prohibition [their emphasis] ... [and] support for public office no man or set of men, who are in sympathy with, and who lend their influence to the liquor traffic."’35

Methodist temperance agitators joined their Baptist brethren and continued to issue reports and resolutions throughout the 1890s and first decade of the 1900s, enunciating many of the same positions and policies. Even more so than the Baptists, however, Methodist temperance committee members became increasingly self-deprecating and bitter in their assessment of their church and its relationship with the liquor question. The 1892 committee acknowledged its shortcomings but also reiterated its strong opposition to alcohol. They admitted that there had been "repeated failures to live up to our own declarations. Yet we cannot forbear expressing

\footnotetext{
${ }^{35}$ West Virginia Baptist Annual and Proceedings of the $25^{\text {th }}$ Annual Session of the Baptist General Association, Held at Alderson, WV, October 17-20, 1889 (Alderson, WV: Argus Printing House, 1889), 24.
} 
again our deep seated convictions upon this great question, with the hope of ultimately rising to the standard of action which our repeated declarations demand."36 Two years later, committee members pointed out their own hypocrisy. Their third resolution stated "that we lament the inconsistency of passing resolutions in our Annual Conference against the liquor traffic, and then voting ... for candidates nominated by political parties that are managed in the interest of said traffic.",37

1895 ME Conference attendees were greeted by a shockingly resigned and frank temperance report. While the committee reemphasized the importance of temperance, the body admitted that it "finds it difficult to formulate a report upon this subject without repeating what has been said many times before, and another embarrassing feature is that Conference resolutions seem to be passed more for ornamentation than use." Like its Baptist counterparts, the 1895 committee also lamented the lack of strong organization and unanimity on the dry side of the liquor issue: "The acknowledged weakness of the temperance cause is its inability to poll its full strength at the ballot box, and it is to be regretted that the Church has not stood together in this matter as it should have done." They also pointed to the liquor traffic's politicization of the prohibition debate and their inability to do the same as "the cry is at once raised 'that the Church is dabbling in politics"" whenever Christians tried to fight fire with political fire. ${ }^{38}$ Members of

\footnotetext{
${ }^{36}$ Official Journal and Minutes of the Forty-Sixth Annual Session of the West Virginia Conference of the Methodist Episcopal Church, Held at Huntington, WV, September 21 to September 26, 1892 (Wheeling: West Virginia Printing Company, 1892), 42.

${ }^{37}$ Official Journal and Minutes of the Forty-Eighth Annual Session of the West Virginia Conference of the Methodist Episcopal Church, Held at Charleston, WV, September 12 to September 17, 1894 (Wheeling: West Virginia Printing Company, 1894), 55.

${ }^{38}$ Official Journal and Minutes of the Forty-Ninth Annual Session of the West Virginia Conference of the Methodist Episcopal Church, Held at Buckhannon, WV, September 18 to September 24, 1895. Also the Lay electoral Conference (Wheeling, WV: WJ Johnston, Printer and Binder, 1895), 55.
} 
the West Virginia WCTU issued a less pessimistic statement in support of prohibition at their annual convention in 1900. However, their resolution still came off more as a reassuring reiteration than a strong, new, or original declaration of principles. WCTU activists stated "that we reaffirm our unfaltering determination to work for the legal prohibition of the liquor traffic.",39

The overwhelming defeat of the statewide prohibition referendum in 1888 did not kill the prohibition movement in West Virginia, but it did leave its adherents disappointed, frustrated, and bitter. After all, as their post-1888 temperance resolutions reveal, they believed that they had lost an unfair war against a diabolical opponent because of that opponent's dirty political deeds and their own lack of commitment, consistency, and organization. These temperance warriors did, however, survive the turn of the century and the first few years of the 1900s without any serious statewide prohibition legislation to support and without a viable or unified organizational structure. They did make it through these tough times with their ideals relatively intact, though, and this allowed the still-developing ASL to tap into an existing reserve of temperance agitators hungry for leadership and a common purpose. Of course, the eventual unification of religious and special-interest prohibitionists and the ASL would not be enough to guarantee dry victory in 1912. It would also be the totality of less glamorous, incremental adjustments to West Virginia's statutory liquor regulation and taxation systems during the largely unnoticed years of the late 1880s through the first few years of the 1900s that would help prepare the political, social, and economic ground for the triumph of statewide prohibition at the 1912 ballot box.

\footnotetext{
${ }^{39}$ Minutes of the $18^{\text {th }}$ Annual Convention of the Women's Christian Temperance Union West Virginia, 1900 (Fairmont, WV: Union Printing, 1900), 48.
} 
As mentioned at the end of chapter three, elements of the West Virginia dry movement began working for gradual adjustments to the state's organic liquor law even before the defeat of statewide prohibition. The mandatory scientific instruction bill, passed during the 1887 legislative session, easily had the most far-reaching consequences of any liquor-related legislation before the turn of the century. Lockard argues that "undoubtedly, strict execution of the law for twenty years was one of the determining factors in the final enactment and enforcement of the prohibition amendment." ${ }^{40}$ Many of the state's most influential churches and temperance organizations cheered on the bill as it made its way through the halls of legislative power. It was the efforts of the WCTU, however, that had the biggest impact on the bill's passage. As part of their campaign, "2000 pages of literature were soon broadcast over the state. Personal letters were addressed to each member of the House and Senate. The names of 1500 teachers to a petition attest their interest in securing a law compelling instruction." ${ }^{41}$ In his triumphal account of the prohibitionist system in West Virginia, Fred Blue made special mention of dry women's roles in the campaign for the instruction law and its long-term importance. According to the one-time prohibition commissioner, "The effect of this legislation - the education of the youth respecting the effects of alcoholic liquors - was seen in the election of 1912. The credit for the aforesaid provision of law belongs to the women of West Virginia. Through the efforts of their organization, the [WCTU], such legislation was enacted."42

This form of political activism, as out of place or inappropriate as it may have seemed to some in the late nineteenth century, was standard operating procedure for many chapters of the

\footnotetext{
${ }^{40}$ Lockard, "The Temperance Movement," 23.

${ }^{41}$ Annual Reports of the WCTU of West Virginia, 1886-1888 (Keyser, WV: Mountain Echo Printers, 1888), 49.

${ }^{42}$ Frederick O. Blue, When a State Goes Dry: A Brief Study in Law Enforcement (Westerville, OH: American issue Press, 1916), 36-37.
} 
WCTU. In fact, "the most successful (although nonpartisan) political campaign waged by the WCTU in the nineteenth century was for compulsory temperance education in the public schools." Every state in the union with the exception of Georgia possessed some form of scientific temperance education by 1903 as a result of WCTU agitation. ${ }^{43}$ The type of direct action exhibited by Mountain State members of the WCTU via the dissemination of propaganda and submission of legislative petitions occurred throughout the organization's infrastructure. One Nebraska woman, for example, testified in Washington, drafted legislation, and offered petitions in 1888. As Bordin asserts, "The WCTU developed lobbying techniques in the 1880s and 1890 s that were used successfully by the Anti-Saloon League in the twentieth century and that have formed the basis for most special-interest lobbying ever since." 44

While WCTU strategies may have been revolutionary, activist women still limited their focus to issues like temperance and prohibition because efforts in these areas did not threaten the clearly defined domestic roles imposed upon them by the nineteenth-century American gender order. According to Baker, "Temperance appealed to women because it addressed a real problem - one that victimized women - and because, as a social problem, it fell within the woman's sphere." ${ }^{45}$ Bordin also discusses this limited version of activism early on in Woman and Temperance. She maintains that "if [women] committed public acts, took public stands, it was only in their role as nurturant mothers who must insure a good environment for those

\footnotetext{
${ }^{43}$ Ruth Bordin, Woman and Temperance: The Quest for Power and Liberty, 1873-1900 (New Brunswick, NJ: Rutgers University Press, 1990), 135-136.

${ }^{44}$ Bordin, Woman and Temperance, 136.

45 Paula Baker, "The Domestication of Politics: Women and American Political Society, 1780-1920," The American Historical Review 89 (June 1984): 637.
} 
dependent on them. The WCTU was a 'safe' women's movement." ${ }^{\text {,46 }}$ While social convention may have limited the field of political activism for female reformers, it would have little impact on the energy and passion of West Virginia's WCTU members when the prohibition amendment campaign reignited after the turn of the century. They would emerge as one of the most important elements of the liquor proscription coalition in 1912.

Gradualist legislation extended well beyond the schoolhouse in the years after and even before the disintegration of prohibitionist political leverage in 1888. This collection of legislative action began with the imposition of a new state constitution in 1872 and extended to the eve of the successful 1912 referendum. Included in this panoply of liquor-related legislation were adjustments and refinements to the state's alcohol licensing and regulation system, the imposition of new and higher taxes on West Virginia's brewing and distilling industries, greater regulation over the transportation of liquor into the Mountain State, and even attempts at alternative means of liquor proscription such as a state distillery system and a true local-option law. Some of these statutory attempts were successful and some were not. Elements of the dry movement supported or even sponsored some of these bills, and others faced teetotaler opposition. While the vast majority of this legislative action was significantly less provocative than earlier efforts at statewide prohibition and rarely attracted much attention in the West Virginia press, the cumulative impact of these adjustments, regulations, and limitations was enormous. As a result of this late nineteenth and early twentieth-century statutory gradualist impulse, it became more dangerous and much more expensive to make, sell, or traffic booze. Ironically, by the time West Virginians gathered to decide on constitutional prohibition, the state was fully invested in and dependent upon alcohol in order to make budget ends meet. In short,

\footnotetext{
${ }^{46}$ Bordin, Woman and Temperance, 8-9.
} 
the situations created and issues raised by these laws and regulations passed during and around what was considered a dead period for the dry movement provided a much more fertile bureaucratic and sociopolitical field for Mountain State prohibitionists in 1912 than they experienced in 1888 .

West Virginia, as mentioned in chapter one, maintained a liquor licensing system from the beginning. However, the 1872-1873 legislature greatly enhanced the existing system and included, among other measures, a civil damage law. According to the clause, which was originally passed in 1873 and, in part, reenacted in 1877, “The person selling liquor, whether with license or not, was held liable for causing intoxication ... [and] was also held liable for suit by a person injured through the actions of one to whom he had sold liquor. Even the owner and tenant of real estate used in the trade were held liable." ${ }^{47}$ This regulation, of course, made running or renting space to a saloon a particularly risky endeavor from a financial standpoint. Essentially, as historian Elaine Frantz Parsons concludes, "In states with civil damage laws, citizens damaged by others' drinking could require that saloonkeepers pick up the tab." Mountain State lawmakers were in relative accord with national trends as twenty-one states had these laws on their books by 1890 . The assumption behind enforcing civil damage statutes - that the saloon owner was the "proximate" reason for a drunk's actions and not the drunk himself turned traditional common law on its head. As Parsons maintains, “A number of state legislatures passed a type of law that appeared to be based on a different notion of legal responsibility than the rest of American law." While some legal experts at the time questioned this, most nineteenth-century citizens and politicians accepted the laws because "they had come to believe that drink purveyors bore a large degree of responsibility for their customers' drinking.

47 Lockard, “The Temperance Movement," 16-17. 
Court officials ... often claimed that habitual drinkers, at least, lacked free will and moral responsibility." ${ }^{48}$ In a 1908 Supreme Court of Appeals case (Duckworth v. Stalnaker), the husband of West Virginian Martha Duckworth actually bragged about how drunk he had gotten, serving as a witness for his own wife. Parsons argues that "in many cases, these failed patriarchs watched, and even testified in, their own wives' trials. Martha Duckworth's declaration in her 1908 trial typically described her husband G.B. as 'feeble and helpless . . . disordered and disabled.',"49

Mountain State lawmakers and their constituents did not appear to have significant legal reservations about their civil damage law as a version of the legislation was still on the books in 1904. The twentieth-century incarnation of the law, by now quite detailed, existed in the license regulation code chapter as "Liability of violators to husband, wife, etc., in damages; how suits brought." 50 Section nineteen of the code was quite similar to the original law. Any proprietor illegally selling liquor to a patron or any landlord who knowingly allowed the sale of liquor on his premises was liable "for all damages sustained, and for exemplary damages" if a drunk customer caused injury to "person or property, or means of support." Married women enjoyed the same legal rights to press charges and collect damages as single women. The law even granted minors the right to damages, although the funds would obviously go to the parents. Saloon keepers who rented their space would have their lease annulled if they illegally sold

\footnotetext{
${ }^{48}$ Elaine Frantz Parsons, Manhood Lost: Fallen Drunkards and Redeeming Women in the Nineteenth-Century United States (Baltimore: Johns Hopkins University Press, 2003), 37, 39-40.

${ }^{49}$ Parsons, Manhood Lost, 70, 201.

${ }^{50}$ Acts of the Legislature of West Virginia at its Extraordinary Session, 1904 (Charleston, WV: Tribune Printing, 1904), 6.
} 
alcohol on premises and the landlord could even lose his property to cover damages. ${ }^{51}$ Clearly, the civil damage laws foisted upon West Virginia saloonkeepers and their landlords, whether directed at injuries resulting from legal or illegal sales, were designed to shift the blame from the drunk himself to the business owner who provided the means to put him in that condition. Functionally, though, since the state set the bar for what it considered to be illegal sales so low, running a tavern around the turn of the century could quickly become a quite expensive, if not ruinous, occupation.

State politicians set the modern bar of illegality during the $1872-1873$ session. Their bill, entitled "An act to provide against the evils resulting from the sale of intoxicating liquors in the state of West Virginia," made it illegal to vend liquor to children, "or to persons intoxicated, or to persons who are in the habit of getting intoxicated."52 The 1877 legislature lowered the threshold for what was considered illegal by including sales to people "of unsound mind" and Sunday vending. Additionally, lawmakers made such sales by licensed saloonkeepers a misdemeanor with fines between twenty and a hundred dollars. ${ }^{53}$ Fourteen years later, the legislature extended its proscription against providing liquor to children and the mentally challenged by including "any person (except for a parent to his child or a guardian to his ward) whether he have a state license or not." The penalties for these illegal sales and dispensations remained the same. ${ }^{54}$ The illegality section took up nearly a page of legislative publications by

\footnotetext{
${ }^{51}$ Acts of the Legislature, 1904, 15.

${ }^{52}$ Acts of the Legislature of West Virginia at its $11^{\text {th }}$ Session, 1872-3 (Charleston, WV: Walker Public Printer, 1873), 253-254.

${ }^{53}$ Acts of the Legislature of West Virginia at its $13^{\text {th }}$ Regular Session, Commencing January 10, 1877 (Wheeling, WV: Johnston Public Printing, 1877), 143.

${ }^{54}$ Acts of the Legislature of West Virginia at its $20^{\text {th }}$ Regular Session (Charleston, WV: Donnally Printers, 1891), 331.
} 
1904. By this time, penalties for illegal sales of any kind went far beyond simple fines. While first-time violators still faced a misdemeanor charge and a fine from twenty to a hundred dollars, a second illegal sales charge meant higher fines, jail time, and even the loss of one's liquor license. $^{55}$

Authorities also reserved the right to deem locations where illegal sales occurred public nuisances. By doing this, local officials could seize and abate these properties. These nuisance provisions, which in 1872 were quite rudimentary, grew over the next 36 years and eventually granted the government significant police power over the property rights of its citizens. ${ }^{56}$ Later versions of the nuisance provisions included penalties directed at the property owner and anyone illegally vending within the property. ${ }^{57}$ Legislators initially appeared to target unlicensed places where sales of liquor took place with these abatement laws. By 1908, however, it became clear that even licensed liquor dealers could be nabbed under the abatement provisions, if they sold their wares illegally. While courts could ban liquor sales at unlicensed nuisances in perpetuity, they now had the authority to ban sales for up to a year at a licensed location and void the license of a legal owner if he vended liquor "contrary to law."58 Mountain State politicians earnestly acted against what they considered to be the evils of the liquor traffic around the turn of the twentieth century when they stringently defined illegality, imposed strict fines and penalties, and threatened abatement. In fact, according to Lockard, "West Virginia from its beginning followed

\footnotetext{
${ }^{55}$ Acts of the Legislature, 1904, 14.

${ }^{56}$ Acts of the Legislature, $1872-3,4$.

57 The fines ranged from 20 to 100 dollars. Jail time of ten to thirty days could also be imposed by the court; Acts of the Legislature, 1877, 144.

${ }^{58}$ Acts of the Legislature of West Virginia, Extraordinary Session, 1908 (Charleston, WV: Tribune Printing, 1908$), 69$.
} 
a system of licensing and waged a fight against the evils resulting from intemperance."59

Criminalizing sales to such a wide swath of the West Virginia population, specifically citizens who were drunk at the time or were in the habit of getting drunk, and holding the state's police power over the heads of even licensed dealers, in reality, cut out quite a large portion of the bar owner's clientele and put the average saloonkeeper in constant fear that the next beer sold might be his last.

Just as it became increasingly tricky to run a liquor business in the Mountain State in the late nineteenth and early twentieth century, the state made the licensing of legitimate liquor outlets more and more expensive and discovered new elements of the alcohol industry to tax. Legislators pegged retail licenses at 20 dollars for native wines and beer and 100 dollars for liquor and foreign wines in $1863 .^{60}$ These rates remained relatively steady for the next few years. In 1885, state politicians decided to require licenses of breweries and distilleries. These alcohol producers were now taxed anywhere between fifteen and 150 dollars, depending on their annual output. Retail licenses increased to one hundred fifty dollars. ${ }^{61}$ The 1887 legislative session further enhanced the taxation of the liquor trade. Politicians raised the brewer and distiller tax to between fifty and $\$ 550$ and the retail tax to $\$ 350$. According to Lockard, "By this system of high licenses the legislators tried to minimize the evils of the liquor trade. At the same time rates were being raised to unprecedented heights on liquor licenses, the tax on real and

\footnotetext{
${ }^{59}$ Lockard, "The Temperance Movement," 11. If evidence in chapter five is to be believed, it is doubtful that local officials fought as hard as their legislative counterparts or actually enforced these laws on a regular basis.

${ }^{60}$ Lockard, "The Temperance Movement," 11.

${ }^{61}$ Acts of the Legislature of West Virginia at its $17^{\text {th }}$ Session, Commencing January 14, 1885 (Wheeling, WV: Taney Printer, 1885), 35-36; Lockard, "The Temperance Movement," 17-18.
} 
personal property remained the same."62 Elements of the hobbled prohibitionist movement in West Virginia were not impressed. Mountain State Baptists, for example, pledged "to set ourselves squarely and firmly against the compromise policy of High License" at their 1889 meeting. ${ }^{63}$ Ten years later, the opinion of Baptist leadership towards the high license system had scarcely changed. In a statement issued by G.A. Winebrenner, "The only righteous attitude of Christian citizenship toward the murderous traffic is that of eternal hostility and perpetual warfare, demanding always and everywhere its legal prohibition and utter suppression.” Additionally, according to Winebrenner, people of faith needed to oppose "any and all candidates, parties, measures or politics that in any way favors license, taxation or any other legal sanction."64

After the turn of the century, lawmakers again increased the cost of making and selling liquor in West Virginia. Charleston raised the retail license fee to $\$ 450$ during the 1904 extra session. By 1909 , it was $\$ 1000 .^{65}$ Mountain State politicians also targeted liquor and beer producers during the extra session. Under the new law, which went into effect on May 1, 1905, distilleries and breweries were required to pay a $\$ 100$ distilling or brewing fee. These producers, whether inside or outside West Virginia, also had to pay "a manufacturer's selling license" in order to carry on a wholesale liquor business. Distillers paid a fee of $\$ 500$. The levy for brewers ranged from $\$ 600$ to $\$ 6000$, depending on annual production. ${ }^{66}$ Perhaps not surprisingly, some

\footnotetext{
${ }^{62}$ Lockard, "The Temperance Movement," 18.

${ }^{63}$ West Virginia Baptist Annual, 1889, 24.

${ }^{64}$ Minutes of the $34^{\text {th }}$ Annual Meeting of the General Association of West Virginia, Held in the Fairmont Baptist Church, Fairmont, WV, October 12-16, 1898 (Huntington, WV: Banner Printing, 1898), 30.

${ }^{65}$ Lockard, "The Temperance Movement," 27.

${ }^{66}$ Acts of the Legislature, 1904, 25-27.
} 
legislators worried during debate about the legislation's constitutionality and whether or not the fees would allow in-state manufacturers to monopolize the liquor and beer business. The Intelligencer, eager to support a Republican-dominated legislative session, maintained that the new measure "introduces new and much needed legislation pertaining to the regulation of the liquor tariff and the enforcement of the liquor laws. ${ }^{967}$ Both newspaper editors and politicians seemed to be most impressed by the potential for extra revenue presented by increases in the retail license, production, and selling fees. This was especially important as one of the main goals of the 1904 session was the limitation of the direct state tax. According to the license bill's supporters, the increased rates were "estimated to create from one hundred to one hundred and fifty thousand dollars per year." ${ }^{, 68}$

State legislators, apparently seduced by the idea of enhancing revenue relatively painlessly, continued the policy of high license that they had begun in the late nineteenth century. In fact, the retail license tax increased over 100 percent in just five years, rising from $\$ 450$ in 1904 to $\$ 1000$ by $1909 .{ }^{69}$ While more and more nervous journalists, politicians, and even elements of the liquor industry would eventually support high license and tout its mitigating influence on the saloon trade as the movement for statewide prohibition reemerged in the latter part of the 1900's first decade, the real importance of the system was that it inextricably tied the West Virginia budget to the alcohol business. When describing the license scheme in America, nineteenth-century prohibitionist Deets Pickett mentioned that "a French prime minister once

\footnotetext{
${ }^{67}$ Wheeling Intelligencer, August 10, 1904.

${ }^{68}$ Wheeling Intelligencer, August 10 and 15, 1904.

${ }^{69}$ Lockard, "The Temperance Movement," 27.
} 
described alcohol as the beast of burden in a budget."70 This truism proved absolutely correct in the Mountain State. Fees and taxes on the West Virginia liquor industry comprised an overwhelming majority of the total license revenue collected at and after the turn of the twentieth century. The total license tax-related revenue collected by the state between July, 1898, and July, 1899 , was $\$ 225,107$. Of that total, $\$ 210,327$ came from retail and wholesale license fees on beer and liquor or the distillery tax. ${ }^{71}$ By the eve of the vote on state prohibition in the summer of 1912 , that amount had tripled. The state collected $\$ 818,741$ in license taxes. $\$ 648,641$ of the total take was derived from liquor-related fees. ${ }^{72}$

In his work on the national prohibition movement, Hamm contends that prohibitionists before the late 1880 s accepted the idea of high license and considered it "a step in the right direction." However, by "the late 1880 s and in the 1890 s, the radical prohibitionists violently denounced the policy of high license. ... The radicals based some of their opposition ... on the liquor industry's support of it, but more important was its failure to lead to total prohibition."73 Many Mountain State drys carried their dislike of high license - and the entire liquor license system for that matter - into the twentieth century. While it is true that increasing license costs were part of the statutory gradualism that helped undermine the saloon system, governmental officials and politicians were the ones behind these adjustments. West Virginia bureaucrats liked the idea of stuffing the state's coffers with more and more revenue produced by an increasingly

\footnotetext{
${ }^{70}$ Pickett, The Cyclopedia of Temperance, 257.

71 “Biennial Report of the Auditor of West Virginia, 1899-1900, Part One (1899)" in Public Documents of West Virginia, Part One (1900-1901) (Charleston, WV: Butler Publishing, 1901), 44-45.

72 "Biennial Report of the Auditor of West Virginia, 1911-1912" in West Virginia Public Documents, 1911-1912, Volume One (Charleston, WV: Union Publishing, 1912), 138.

${ }^{73}$ Richard F. Hamm, Shaping the Eighteenth Amendment: Temperance Reform, Legal Culture, and the Polity, 18801920 (Chapel Hill: University of North Carolina Press, 1995), 27.
} 
confiscatory licensing scheme. West Virginians who fought against liquor and the saloon did not. They believed that a high license system effectively put the state in the alcohol business. The ASL made its position on the entire license system crystal clear in the 1909 edition of its Yearbook: "The Anti-Saloon League stands unalterably opposed to a system of license, high or low." According to the group, "If the saloon as an institution is right, it should be as free as the grocery business or the dry goods business, and if it is wrong, its recognition by the government cannot be made right for the consideration of so many dollars per year.",74

Brewers and saloonkeepers found West Virginia a particularly unfriendly place in which to do business after the turn of the twentieth century. Facing a more and more combative population every day as a result of the scientific instruction bill, those engaged in the liquor trade also contended with a much broader definition of illegal sales, the possibility of civil damage suits, property abatement, and much higher fees. This statutory gradualism, while theoretically designed to safeguard the people of the Mountain State from the deleterious effects of alcohol, functionally choked the alcohol industry in an increasingly suffocating shroud of regulation and taxation. It is important to note that many of these measures were the result of bureaucratic adjustment rather than of prohibitionist activism. While politicians passed legislation like the instruction bill as a result of dry activism, most of the alcohol-related bills passed around the turn of the century had more to do with regulating and milking the liquor trade for money than with destroying the industry. However, as the early years of the twentieth century ticked away and the ASL emerged as a viable political force, the legislative impetus shifted from regulation and revenue maximization toward limitation and eventually prohibition.

\footnotetext{
${ }^{74}$ Ernest H. Cherrington, ed., The ASL Yearbook: An Encyclopedia of Facts and Figures Dealing with the Liquor Traffic and Temperance Reform, Volume 2 (1909) (Columbus, OH: ASL Publishing, n.d.), 176.
} 
This change began in 1903 when Governor A.B. White, the second in a long, almost uninterrupted string of Republican governors before the Depression, called for an end to the cash on delivery (COD) liquor system during his first biennial message to the legislature. ${ }^{75}$ Lockard $^{\circ}$ maintains that this plea "cleared the path for the first act of consequence since the one dealing with scientific instruction in schools." ${ }^{, 76}$ While statutory gradualism proved that this is a bit of an overstatement, Lockard is correct in one respect. Governor White's statement supporting regulations designed to eliminate COD liquor shipments from out of state was the first, even mildly, prohibitionist official utterance by a West Virginia chief executive in years. In it, White stated that "a prevalent source of disorder and trouble, in communities where the sale of liquor is not legalized, is the COD liquor business. ... It is the practice for unscrupulous agents of the transportation companies to permit anyone who wants liquor to 'claim' one of these packages." In essence, out-of-state liquor dealers would ship packages of alcohol into a West Virginia dry county under a false manifest and an employee of the shipping company would vend the liquor to a citizen, thus rendering moot the county-level prohibition measure. According to the governor, "If there is any way by which this unlawful sale of liquors can be broken up it is the duty of the Legislature to find a remedy."77

The 1903 legislature jumped to its duty. An anti-COD bill passed the senate by a vote of twenty-six for and zero against on February 25, and the house gave its assent fifty-nine to zero

\footnotetext{
${ }^{75}$ Dillon, West Virginia Blue Book, 1976, 239.

${ }^{76}$ Lockard, "The Temperance Movement," 26.

77 First Biennial Message of Governor AB White to the Legislature of West Virginia, Session of 1903 (Charleston, WV: Tribune Printing, 1902), 94.
} 
the next day. ${ }^{78}$ The measure stipulated "that any agent or employee of any person, firm or corporation, carrying on the business of a common carrier, or any other person, who, without a State license for dealing in intoxicating liquors, shall engage in the traffic or sales of such liquors" would be charged with a misdemeanor for illegal sales, fined between ten and a hundred dollars, and faced the possibility of up to six months in the county jail. The law did exempt licensed wholesale dealers and those who "ordered [liquor] for his personal use.",79 West Virginia's constraint of the COD liquor trade was part of a larger national movement to keep illegal liquor shipments out of existing dry territories. Hamm argues that "as the Anti-Saloon League began to assert its dominance over the temperance movement, the prohibitionists sought to limit the COD liquor industry." As a result of these efforts, fifteen states with varying degrees of liquor proscriptions had passed anti-COD laws by 1907. Of course, because these measures affected interstate commerce, there were concerns over their constitutionality. These questions "caused the Anti-Saloon League to alternate between boosting and condemning them." 80

The ASL apparently did not concern itself with constitutional matters in West Virginia. The group "claimed to have 'secured' the passage of the West Virginia law, praised its operation, and touted it as the best law in the country." 81 While aware of the constitutional implications of anti-COD legislation, Governor White nevertheless tacitly supported even national measures barring liquor shipments into dry areas. A few weeks before his requested West Virginia

\footnotetext{
${ }^{78}$ Journal of the Senate of the State of West Virginia for the $26^{\text {th }}$ Regular Session, Commencing January 14, 1903 (Charleston, WV: Tribune Printing, 1903), 699; Journal of the House of Delegates of the State of West Virginia for the $26^{\text {th }}$ Regular Session, Commencing January 14, 1903 (Charleston, WV: Tribune Printing, 1903), 838-839.

${ }^{79}$ Acts of the Legislature of West Virginia at its $26^{\text {th }}$ Regular Session (Charleston, WV: Tribune Printing, 1903), 130.

${ }^{80}$ Hamm, Shaping the Eighteenth Amendment, 181-184.

${ }^{81} \mathrm{Hamm}$, Shaping the Eighteenth Amendment, 184.
} 
measure passed in Charleston, White wrote Senator Stephen B. Elkins in Washington and asked for his opinion on a House of Representatives bill in senate committee that would have regulated interstate liquor commerce. The governor offered his own measured opinion in the letter: "This [legislation] seems to be in harmony with the home rule idea. ... And yet, there is to be considered the right of the individual to purchase where he pleases for his own use." While White avoided issuing an official statement, he did assert that "it seems to appeal to the right of self-government and home rule as to police regulations." ${ }^{, 82}$ The governor's plea in his address and his statement on the federal anti-COD law are instructive in that they illuminate the turn of the century tension between personal liberty, home rule, and state authority - a tension that informed the debate over statewide prohibition as the first decade of the 1900s marched on. White was careful to acknowledge the personal liberty of men who legally ordered booze for their own use, but he ultimately sided with the principles of locally-enforced regulations and home rule. Link confirms this private to public shift when he contends that "in the last two decades of the nineteenth century, this [individualistic] approach to temperance reform underwent a significant transformation: temperance increasingly embraced more public solutions."

The most public solution proposed in early 1900s West Virginia before the rebirth of statewide prohibition agitation emerged in 1903 when the state senate considered a bill establishing a state-run liquor dispensary. This legislation, patterned after the South Carolina dispensary system, would have put the West Virginia state government in charge of alcohol

\footnotetext{
${ }^{82}$ White to Elkins, February 6, 1903, A.B. White Papers, Box 36, West Virginia and Regional History Collection, West Virginia University, Morgantown, WV; Elkins did respond to White's query. His response letter is missing from his correspondence.

${ }^{83}$ William A. Link, The Paradox of Southern Progressivism, 1880-1930 (Chapel Hill: University of North Carolina Press, 1992), 39.
} 
distribution and sales throughout the state. The idea of a dispensary-based regulatory structure had the unique trait of appealing to absolutely no one on either side of the liquor debate. For example, the Wheeling Intelligencer, hardly a bastion of dry sentiment, blasted the bill after it emerged from the judiciary committee: "There is not a single redeeming feature in the measure." The Intelligencer's editors argued that the current license system was "sufficient if enforced" and "that where the liquor traffic is now successfully regulated where it cannot be abolished, the dispensary system would be wholly demoralizing; that in place of saloons controlled by law, speak easies would spring up to work twice the corruption that now exists." ${ }^{84}$ Senators apparently agreed with this Republican organ's criticism. Only a few days after its appearance in the senate, legislators overrode a motion to make the measure a special order and recommitted it to committee. This decision effectively "killed the bill for good." 85

State officials and leading dry groups also rejected the idea of a state-run liquor sales system as the idea continued to circulate after its 1903 legislative rejection. Governor White assailed the dispensary scheme in his farewell address to the 1905 legislative session. White, who had compelled an earlier legislature to pass a prohibitionist-backed anti-COD law partially designed to defend the sovereignty of the state's liquor license system, again came to the system's defense. As he contended, “There has been considerable discussion of late about the propriety of West Virginia adopting a State dispensary system similar to that of South Carolina. I am not favorably impressed with the practical workings of that system, nor do I think the time propitious for enacting such a radical change in our license tax system." 86 A few years later, the

\footnotetext{
${ }^{84}$ Wheeling Daily Intelligencer, February 18, 1903.

${ }^{85}$ Wheeling Daily Intelligencer, February 20, 1903; Journal of the Senate, 1903, lii, 614, 619.

${ }^{86}$ Biennial Message of Governor A.B. White to the Legislature of West Virginia, Session of 1905 (Charleston, WV: Tribune Printing, 1905), 26.
} 
ASL weighed in on the dispensary scheme in its 1908 Yearbook. While the organization admitted that a similar system had been somewhat successful in Norway, it still rejected the scheme's effectiveness "under a republican form of government." According to the ASL, the dispensary "is not only of no benefit as a reform measure, but proves a peculiarly fruitful source of corruption and graft." The legislative rejection of South Carolina's system and its subsequent replacement with local option in 1907, according to the group, confirmed the futility of such a state-run vending system. ${ }^{87}$ Ironically and unfortunately, Mountain State bureaucrats would be much more receptive to the idea of a state-run liquor monopoly after the downfall of statewide and national prohibition during the Great Depression, and the Intelligencer and ASL would both prove prescient in their opinion that such a system lent itself to corruption and graft.

The fact that a newspaper located in the de facto capital of Mountain State "wetness" and the leading twentieth-century prohibition organization in America agreed on the uselessness of the dispensary scheme, while superficially odd, makes sense if one considers the nature of the wet-dry debate during the first decade of the 1900s. Indeed, the very structure of dispensary legislation, which essentially put the state in the monopolistic business of selling liquor, provoked responses on the liquor and anti-liquor sides that provided insight into each camp's position and exposed important elements of their respective arguments. The alcohol industry saw the dispensary as a bureaucratic usurpation of the saloon owner's right to vend liquor to the West Virginia public and the literal end of the private liquor industry in the Mountain State. The ASL, on the other hand, disliked the measure because it did not consider it a positive step in the direction of saloon elimination and statewide prohibition. After all, if drys rejected the license system because it put the state in bed economically with the liquor industry, they could hardly

\footnotetext{
${ }^{87}$ Ernest H. Cherrington, ed., The ASL Yearbook: An Encyclopedia of Facts and Figures Dealing with the Liquor Traffic and the Temperance Reform, Volume 1 (1908) (Columbus, OH: ASL Publishing, n.d.), 138-139.
} 
have been expected to accept a regulatory scenario that actually made the West Virginia government the sole alcohol dealer in the state.

The battle over statewide prohibition reignited during the 1907 session when legislators considered a prohibition measure; it failed to pass both chambers. ${ }^{88}$ Ultimately, though, the 1907 bill proved to be as misleading as it was unsuccessful. Unlike the first major upsurge of agitation for a prohibitory law in the 1880 s, the twentieth-century dry campaign, now composed of a much more dynamic confederation of anti-liquor groups with the ASL at the helm, rejected the nineteenth century movement's zero-sum obsession with immediate statewide prohibition. Between 1907 and 1910, teetotalers openly supported any law or additional regulation as long as they considered it progress towards the elimination of the Mountain State saloon trade. West Virginia drys, in fact, would not hone in exclusively on a statewide prohibition amendment until such a measure showed considerable promise during the 1911 legislative session. In short, while the 1907 bill did signal the beginning of an uptick in anti-alcohol sentiment in the Mountain State, it did not presage a prohibition-only political campaign during the first few years of the 1900s.

Many members of the West Virginia "wet" alliance, which included brewers, saloon owners, and several of the leading newspapers in the state, did not react to the twentieth-century anti-liquor movement the same way they did before the turn of the century. Because dry groups and politicians placed options other than total prohibition on the table before 1912, the campaign against alcohol after the turn of the century did not boil down to an unconditional contest between wet and dry until the 1911 legislature authorized a referendum on statewide prohibition. Operating as a foil to their dry nemeses, elements of the Mountain State liquor coalition were

\footnotetext{
${ }^{88}$ Lockard, “The Temperance Movement," 27.
} 
willing to accede, however unhappily, to even more increasingly restrictive alcohol laws as long as these measures fell short of prohibition. This newfound, albeit conditional, flexibility was partially a result of the fact that, through their gradual construction of a particularly onerous and confiscatory regulatory environment before and after the turn of the twentieth century, West Virginia bureaucrats had backed saloon owners and their wet allies into an economically and legally precarious corner. In addition, some of these same politicians, especially the new crop of marginally progressive, Republican governors, no longer ignored the liquor issue. In fact, some even went so far as to comment on and even support publically various proposed measures limiting the Mountain State alcohol trade.

Formerly sopping-wet newspaper editors and even pro-liquor lobbying groups also began to strike a more conciliatory tone towards regulation because they no longer enjoyed the support, or even indifference, of the great electoral middle. Wets thwarted dry legislation in the 1880 s, in part, because most Gilded Age West Virginians either had little problem with the saloon or simply had no opinion. However, after the turn of the century, the great undecided middle was no longer so undecided. According to historian Larry Engelmann, "During the first two decades of the twentieth century hundreds of thousands of Americans changed their attitude toward the saloon. Rather than the church of the poor, the saloon was considered more and more the devil's headquarters on earth." ${ }^{89}$ A number of conditions and realizations compelled formerly disinterested citizens to change their tune. As Engelmann contends, "Critics showed ... that every social service provided by the saloon was balanced by a dozen disservices and every blessing of the saloon by a host of curses." These anti-saloon commentators claimed that the saloon created violence, bred corruption, and even helped support prostitution. Opponents also

${ }^{89}$ Larry Engelmann, Intemperance: The Lost War Against Liquor (New York: The Free Press, 1979), 8. 
argued that "the principle victims of the saloons ... were not the strong and the sophisticated, but the young and the innocent and the poor." 90

Additionally, as brewery and distillery consolidation accelerated around the turn of the twentieth century, beer and liquor manufacturers "were also open to censure as monopolies." According to Cashman, "Intense competition among the [monopolistic] brewers drove them to control the retail sale of their beer." Saloon owners, who buckled under the pressure of increasingly confiscatory license fees, ended up selling out their business to a brewer, and "once he became the brewers' front the small saloonkeeper was obliged to flout the liquor laws and take part in vice and criminal activities to stay open. The Sunday-closing regulations were widely ignored." Finally, the burgeoning mechanization of the workplace created yet another justification for the growing prohibition movement around the turn of the century as "accidents arising from drunkenness at work were more dangerous than before. Mistakes with mechanical drill, loader, and conveyor belt had more damaging consequences than those with pickax, shovel, and wheelbarrow operated by hand."91 One former Democratic politician in West Virginia even blamed coal mine accidents on drunkenness at a 1908 dry rally. According to former state senator and Attorney General C.C. Watts, "The majority of mine disasters which have so stirred West Virginia in recent years have been due to the miners taking whiskey into the rooms."92 In spite of all its attending problems and costs, Americans "concluded that the worst of the evils of the saloon was that saloons created drinkers and drunks. . . Doing away with the saloon and its allied interests - brewers and distillers - would not necessarily end drinking and

\footnotetext{
${ }^{90}$ Engelmann, Intemperance, 8.

${ }^{91}$ Sean Dennis Cashman, Prohibition: The Lie of the Land (New York: The Free Press, 1981), 4-5.

${ }^{92}$ Wheeling Register, February 10, 1908.
} 
drunkenness in America. But it would certainly decrease those evils." "93 The ASL was happy to tap into this burgeoning anti-saloon attitude, and Mountain State Protestant churches were eager to lend their support to the organization. Baptists, Methodists, and Presbyterians all issued support statements, sent delegates to ASL conventions, or even directly aligned themselves with the League around the turn of the century. The West Virginia Baptist General Association, for example, appointed two delegates to the 1896 ASL convention in Wheeling. ${ }^{94}$ The Methodists, long regarded as a dry bulwark in the Mountain State, soon followed suit. In 1903, annual session attendees choose two delegates to go to the national ASL convention. ${ }^{95}$ They went even further three years later. Conference attendees decided to "recognize the West Virginia ASL as one of the authorized agents of the Church in their temperance work, and heartily approve of its efforts to improve the statutes in relation to the liquor business, and at the same time build up a public sentiment so strong ... as to speedily bring about ... state-wide prohibition."96 This Methodist-ASL alliance followed national trends. According to Timberlake, the Methodist Church moved beyond issuing support statements and "entered into an organic relationship with [the ASL]. Thus, many of the Methodist Episcopal Church's leading temperance officials were also high in the league's councils." $" 97$ The Presbyterian Church also endorsed the ASL around the turn of the century. While the West Virginia synod made no specific mention of the League in

\footnotetext{
${ }^{93}$ Engelmann, Intemperance, 9-10.

${ }^{94}$ Minutes of the $32^{\text {nd }}$ Annual Meeting of the Baptist General Association of West Virginia, Held in the First Baptist Church in Wheeling, WV, October 14-18, 1896 (n.p., n.d.), 27.

${ }^{95}$ Official Journal and Minutes of the $57^{\text {th }}$ Annual Session of the West Virginia Conference, Methodist Episcopal Church, Sessions, Held at Wheeling, West Virginia, September 30 to October 5, 1903 (Published by the Secretaries, c. 1903), 73.

${ }^{96}$ Official Journal and Minutes of the West Virginia Conference of the Methodist Episcopal Church, $60^{\text {th }}$ Annual Session held at Sistersville, WV, October the third to the eighth, 1906 (Published by the Secretaries, c. 1906), 90-91.

${ }^{97}$ Timberlake, Prohibition and the Progressive Movement, 20.
} 
its early twentieth century minutes, “the church's General Assembly officially endorsed the league as a 'sane, safe, and effective organization in the advancement of the great cause of temperance"" by $1907 . .^{98}$

This church-oriented alignment is what made the ASL different, and ultimately more successful, than earlier temperance organizations. The ASL operated as a confederation of likeminded individuals. As Engelmann asserts, "The basic grass-roots financial and electoral strength of the league lay with local church congregations. ... The league worked as a political pressure group, collecting funds from church congregations and independent donors." While the ASL struggled before the turn of the twentieth century, it gained so much support in the early 1900s "that by 1908 only four states were without state league organizations. Between 1905 and 1915 the number of churches cooperating with the league increased from 19,000 to 40,000."99 P.A. Baker, the ASL's General Superintendant, defined his organization in the inaugural edition of the Anti-Saloon Year Book in 1908:

The Anti-Saloon League is not, strictly speaking, an organization. It is what its name indicates - a League. It is a league of organizations. It is the federated church in action against the saloon. Its agents are of the church, and under all circumstances loyal to the church. It has no interest apart from the church. It goes just as fast and just as far as the public sentiment of the church will permit. It has not come to the Kingdom simply to build a little sentiment, or to secure passage of a few laws, nor yet to vote the saloons from a few hundred towns. These are mere incidents in its progress. It has come to solve the liquor problem. $^{100}$

\footnotetext{
${ }^{98}$ Timberlake, Prohibition and the Progressive Movement, 20.

${ }^{99}$ Engelmann, Intemperance, 10-11.

${ }^{100}$ Cherrington, The ASL Yearbook, 1908, 5.
} 
Baker made the aims of the League clear. It is important to note that the League had no interest apart from eliminating the saloon. Earlier groups like the WCTU and Prohibition Party had weighed in on other social issues. The ASL, though, "specialized by focusing continuing attention on a single issue, prohibition, and by refusing direct involvement with other issues. . . The league consistently refused to distract attention, and potentially to lose supporters, by straying from its single purpose."101 ASL officials also refused to be distracted by partisanship and party politics. The League used political pressure to achieve their prohibitionist goals. One scholar in the 1920 s even "saw the league as a pioneering pressure group, one that was important for comprehending the emerging American system of political expression."102 ASL officials, however, saw a difference between using politics and aligning the group with specific parties. At their organizing convention in late 1895, League founders promised to "avoid affiliation with any political party as such and to maintain an attitude of neutrality upon questions of public policy not directly and immediately concerned with the traffic in strong drink.",103

The ASL attacked the saloon from almost every conceivable angle. According to Timberlake, "No facet of the liquor problem was neglected: religious, scientific, social, economic, and political - all were thoroughly exploited."104 One of the League's most effective avenues for propaganda was its use of periodicals. Employing special-interest newspapers was certainly not a new approach to disseminating prohibitionist information as the West Virginia Prohibition Party used the Freeman for that purpose before the turn of the century. The ASL, however, developed a nationwide network of widely circulated publications that complemented

\footnotetext{
${ }^{101}$ Kerr, Organized for Prohibition, 6.

${ }^{102}$ Kerr, Organized for Prohibition, 3-4.

${ }^{103}$ Quoted in Timberlake, Prohibition and the Progressive Movement, 127.

${ }^{104}$ Timberlake, Prohibition and the Progressive Movement, 139.
} 
their efforts on the ground and in the churches. They authorized the American Issue as their national newspaper in 1907, published their first Anti-Saloon League Yearbook in 1908, and circulated other "books, pamphlets, folders, leaflets, and tracts by the million." The 1909 construction of a new printing facility located in Westerville, Ohio, greatly enhanced these efforts. By 1912, "its eight presses were turning out more than 40 tons of literature a month, equivalent to 250 million book pages a year." More than half a million copies of state-level versions of the American Issue also circulated in 31 states. ${ }^{105}$ The League printing press published a West Virginia edition of the American Issue for the first time in early 1910. ASL officials designed the bi-monthly organ to fuse national League news with state-level stories that did not fit in the nationwide edition. A state-level edition also helped the ASL keep pace with local politics and elections and mold its propaganda to the specific circumstances of the Mountain State and its voters. ${ }^{106}$

The West Virginia WCTU only added to the ASL's onslaught of prohibitionist agitation and propaganda. Just as the ASL caught its stride at the beginning of the twentieth century, the Mountain State WCTU switched leadership and enjoyed an organizational renaissance of its own. Lenna Yost became president of the state chapter in 1909. The WCTU quickly benefited from her leadership as "thirty new unions were reported organized" in her first year. In 1910, WCTU members' work included "62 speech contests, 643 bushels of fruits and vegetables delivered to the needy, 537 visits to public institutions, 6,348 floral gifts distributed and 97,228 pages of literature distributed."107 Historian Karina Thurston contends that "the conversion of

\footnotetext{
${ }^{105}$ Timberlake, Prohibition and the Progressive Movement, 138-139.

${ }^{106}$ American Issue (West Virginia Edition), January 17, 1910, 2.

${ }^{107}$ Mrs. Ned Johnson, ed., Mountaineer Memories (undated typescript), 12.
} 
public opinion against the saloons seemed to be of great importance to Yost. Moreover, she seemed fully aware of the role that the media played in influencing public opinion." This realization compelled Yost to rally her forces: "In her 1910 presidential address, she ordered 'that a great literature and press campaign be launched' on prohibition issues." ${ }^{108}$ The president and her executive committee also took "the initiative to bring about a meeting of the Prohibition Party, the Anti-Saloon League, and the WCTU.",109

Such a meeting between the ASL and WCTU would not have been out of the question in early 1900s West Virginia. After all, in 1908, League officials stated that "probably no temperance organization in the world has done more for the cause of temperance along the lines of education and agitation, than the W.C.T.U." They even asked the WCTU's national president to provide a mission and method statement for the 1908 Year Book's section on "Temperance Societies." ${ }^{110}$ Mrs. Yost's own husband also played a key role in the eventual success of statewide prohibition in West Virginia. According to Thurston, "Ellis and Lenna Yost not only shared a domestic life but also political and social ideals; both of the Yosts were ardent Republicans. Ellis Yost fully supported his wife's career and her political accomplishments.” Mr. Yost eventually joined the legislature and, in 1913, sponsored the state prohibition enabling act - House Bill Number Eight - that would eventually become known as the "Yost Law."111

\footnotetext{
${ }^{108}$ Karina Thurston, “Lenna Lowe Yost, Temperance, and the Ratification of the Women's Suffrage Amendment by West Virginia" (MA thesis, West Virginia University, 2009), 26; see pp. 24-29 for more on Yost's impact on the campaign for statewide prohibition.

${ }^{109}$ Thurston, “Lenna Lowe Yost,” 26; Johnson, Mountaineer Memories, 12.

${ }^{110}$ Cherrington, The ASL Yearbook, 1908, 220-221.

${ }^{111}$ Thurston, “Lenna Lowe Yost," 4, 14, 27.
} 
A few days after the 1908 extra legislative session convened in Charleston, the Huntington Dispatch ran an editorial entitled "Rights of the Saloon Men." In it, the editors acknowledged "that prohibition sentiment has made somewhat remarkable strides throughout the south during the past five years. It is equally true that this sentiment is, in a lesser degree, reflected in the general feeling throughout our own state." 112 This rather parsed admission, as painful as it may have been for the journalists to write, was also true. The ASL, which had barely awakened from its turn of the century slumber, reveled in the progress of dry sentiment in the Mountain State by the end of 1908. According to J.C. Jackson, editor of the American Issue, "starting with twenty-four dry counties in 1902, in which the law was poorly enforced, with the 'speak-easy' and 'C.O.D.' business everywhere, West Virginia now has thirty-three dry counties, the express companies refusing C.O.D. shipments of liquor, and the laws are well enforced.",113 Given the fact that there existed over forty dry counties in the early 1880 s, and that the figure dipped to twenty-three in 1902 before rebounding to thirty-three only six years later, Mountain State residents were clearly beginning to climb back on the water wagon.

This rebirth of teetotaler sentiment in West Virginia and around the country did not escape the attention of the alcohol industry and its allies. Saloon owners, brewers, and distillers faced a leaner and meaner dry movement after the turn of the twentieth century than they had in the 1800s. A growing number of wet interests determined that they would have to repel the antisaloon propaganda phalanx with a new, defensive strategy of their own. The liquor trade enjoyed the protection of three main groups: the United States Brewers Association (USBA), the National Retail Liquor Dealers Association, and the National Wholesale Liquor Dealers

\footnotetext{
112 Huntington Dispatch, February 2, 1908.

113 J.C. Jackson, "The Work of the Anti-Saloon League," Annals of the American Academy of Political and Social Science, Volume 32, Regulation of the Liquor Traffic (November 1908): 12, 23.
} 
Association. Timberlake observes that the USBA was "the richest and most powerful of the three organizations."114 The USBA was by no means a new organization. American brewers formed the association in 1862 with the goal of lowering the federal beer tax. ${ }^{115}$ By 1908 , however, their cause had changed. Recognizing that the ASL was a direct threat to the American saloon, the president of the USBA "advocated that the association work in concert with local police, judges, landlords, bonding companies, and licensing authorities to control, in his eyes ... the small proportion of saloons that disturbed the social order." President Julius Liebmann also named Hugh Fox the USBA's new secretary in 1908. The brewers, along with Fox, recognized that "even if the Anti-Saloon League were to disappear, public sentiment was such that major problems would remain. The appropriate strategy was a continuous educational effort to change public opinion, coupled with regulatory laws."116

Secretary Fox addressed "The Saloon Problem" in the same issue of the same journal in which J.C. Jackson had boasted about the effectiveness of the ASL in West Virginia. Fox attacked prohibitionists as rash, impatient, and even "half-educated." He asserted "that the destruction of the saloon does not solve what is called the liquor problem." Quoting a recent trustees report, Fox maintained that "the best working solution for the social control of the sale of liquor that has yet been devised is the licensing system. To be successful, however, the license must be so conditioned that it insures stability in the business, and compels the licensee regard obedience to law and order as essential to the continuation of his franchise."117 The

\footnotetext{
${ }^{114}$ Timberlake, Prohibition and the Progressive Movement, 106-107, 157.

${ }^{115}$ Cashman, Prohibition, 3.

${ }^{116}$ Kerr, Organized for Prohibition, 174.

${ }^{117}$ Hugh F. Fox, "The Saloon Problem," Annals of the American Academy of Political and Social Sciences, Volume 32, Regulation of the Liquor Traffic (November 1908): 62-63.
} 
secretary and other elements of the USBA leadership had clearly centered the alcohol industry's first line of defense on the concept of socially responsible licensing. In order to present this defensive strategy more effectively, association leaders decided to make the Yearbook's content more accessible to those outside the beer business. Additionally, Fox reworked the USBA's bureaucratic structure (to varying degrees of effectiveness) and improved the association's publicity apparatus. ${ }^{118}$ The 1909 USBA Yearbook reflected this change in strategy. According to the non-copyrighted publication's preface, "The Year Book is designed both for the convenience of our own members, and for the information of the public. We have aimed to make it a valuable reference book, not only for brewers, but for all serious students of the liquor question." ${ }^{119}$ Similar to its dry enemy, the USBA also published and disseminated vast quantities of wet propaganda. These documents, which had "a distinct educational aim and purpose," numbered in the dozens and included topical reports, reprinted papers and speeches, and leaflets. ${ }^{120}$

In one way, the prohibition battle lines drawn towards the end of the first decade of the 1900s were better defined than those in the 1880s. Dry and wet West Virginians now enjoyed the organizational, philosophical, and even financial backing of relatively well-organized and well-funded national groups. On the other hand, however, the battle lines were not as clear. Mountain State prohibitionists and their national allies seemed more willing to accept any gradual step in the direction of statewide liquor proscription, especially after 1908. The West Virginia liquor industry and its allies, on the other hand, seemed more willing to settle for semi-

\footnotetext{
${ }^{118}$ Kerr, Organized for Prohibition, 174-176.

${ }^{119}$ Year Book of the United States Brewers' Association (New York: United States Brewers' Association Publishers, 1909), 5.

${ }^{120}$ Year Book of the USBA, 1909, 166-168.
} 
prohibitory limits as long as these restrictions did not eliminate the trade or shutter the saloons. Each side was able to test its strength during the 1908 extra session of the legislature. The ASL began its petition campaign nearly a week before the body's opening. These appeals, prepared and disseminated throughout the state by the West Virginia chapter of the League, aimed high and asked the extra session to submit a prohibition amendment to the people. ${ }^{121}$ The popular pull of the Mountain State ASL was undeniable. By the time the vote on a prohibitory amendment came up in early February, the League had secured 26,000 signatures. ${ }^{122}$ Governor Dawson, however, crippled the push for statewide prohibition early in the extra session by favoring local option over a prohibitory measure in his legislative message. While he accepted the idea of submission if the legislators deemed it popular enough, Dawson stated that "I do not believe [prohibition] is the best way to deal with the evils of the traffic in intoxicating liquors, preferring a strict and stringent local option measure, which is prohibition where public sentiment will sustain it."123 The governor's preference for local option was more than rhetorical. Indications were that, had a prohibitory amendment passed the legislature, he would have vetoed the bill in favor of an additional special session charged with passing local option. ${ }^{124}$

Ultimately, "dry" agitators and their political allies could not overcome gubernatorial resistance and senatorial opposition to statewide prohibition. As it had so many times before, the amendment passed the House of Delegates by a vote of sixty-seven to eleven. The Intelligencer surmised that "the appeals from home changed the vote of many of the delegates." 125 Once the

\footnotetext{
${ }^{121}$ Huntington Dispatch, January 23, 1908.

122 Morgantown New Dominion, February 5, 1908.

${ }^{123}$ Quoted in Charleston Gazette, January 29, 1908.

${ }^{124}$ Huntington Dispatch, February 1, 1908.

${ }^{125}$ Wheeling Intelligencer, February 6, 1908.
} 
measure proceeded to the upper chamber, however, the sparks began to fly. Drys and wets accused each other of attempting to influence the outcome of the senate's vote. One story alleged that the liquor industry met in Charleston and pledged "between $\$ 100,000$ and $\$ 150,000$ " to oppose statewide prohibition. The charge was serious enough to prompt a legislative investigation. ${ }^{126}$ West Virginia ASL president Theodore Alvord offered to testify in front of the senate investigative committee, claiming "that I have in my possession facts which I am sure, if investigated, would lead to a discovery of the truth of these rumors." The senate also investigated charges "that detectives employed by the Anti-Saloon League are watching the senators." This atmosphere of paranoia did not go unnoticed by the Mountain State press. One reporter opined that "the upper house has become very touchy during the present session, and their efforts to run down and strangle every wild rumor that becomes current have become amusing." 127

While the wild proceedings in the senate may have amused Mountain State journalists, the fate of the prohibition amendment did not amuse ASL leadership or its supporters. Once again, senators rejected an anti-liquor resolution. The bill received nineteen votes for and eleven against - one vote short of the mandated two-thirds majority. Of the eleven senators who rejected statewide prohibition, nine of them hailed from wet, or at least partially wet, counties. ${ }^{128}$ President Alvord was not pleased with the outcome. The Register quoted him as stating that "yes, I am a little disappointed, but I have no hard feelings against the senators who voted against the amendment. I think their constituents will settle with them. No, we will not be

\footnotetext{
${ }^{126}$ Huntington Dispatch, February 8, 1908.

${ }^{127}$ Morgantown New Dominion, February 13, 1908.

${ }^{128}$ Morgantown New Dominion, February 14, 1908; Cherrington, The ASL Year Book, 1908, 192.
} 
satisfied with local option. We have just begun the fight . . . and prohibition is going to win."129 The 1908 session was not, however, a complete flop for West Virginia teetotalers. ASL agitation, according to the Register, did result in the "enforcement of the Sunday closing law."130 This enforcement actually took the form of a brand-new measure entitled "an act to make more effective the prohibition of the sale of intoxicating liquors on the first day of the week, commonly called Sunday." The law set quite specific Sunday closing regulations for saloons, levied heavy fines and punishments for violators, and empowered courts to pull liquor licenses and shutter recalcitrant bars. ${ }^{131}$

Mountain State drys got a small part of what they wanted with the passage of the Sunday closing law. Wets, on the other hand, got something they were willing to accept with the authorization of a higher municipal liquor license rate in Wheeling. West Virginia's leading wet newspapers presaged Hugh Fox's statements in support of the license system later in 1908 by rallying around higher license fees for Wheeling saloons. The new rates increased the city license from $\$ 350$ to $\$ 500$ a year. ${ }^{132}$ According to many Mountain State editors, particularly those employed in the state's brewing and saloon capitol, higher licensing fees on bars were the way to go. According to the Register, "High license is . . expected to improve the character of the saloons, and to drive out many of the disreputable places. With decently conducted saloons, yielding increased revenue to the city, there will be no excuse so far as Wheeling is concerned, for constant agitation of the prohibition question."133

\footnotetext{
${ }^{129}$ Wheeling Register, February 15, 1908.

${ }^{130}$ Wheeling Register, March 5, 1908.

${ }^{131}$ Acts of the Legislature, 1908, 70-71.

${ }^{132}$ Wheeling Intelligencer, March 2, 1908; Morgantown New Dominion, March 4, 1908.

${ }^{133}$ Wheeling Register, March 3, 1908.
} 
In addition to running "dives" out of business, raising city funds, and perhaps even forestalling the efforts of groups like the ASL, Wheeling newspapermen also maintained that higher license fees, working in concert with strict Sunday laws, could even clean up political and police corruption. The editor of the Register, who incorrectly credited the League with securing high license fees, argued that the two new regulations would free saloon owners from promising support to local politicians in order to secure "immunity from punishment for violations of the Sunday closing law." These laws would also liberate the saloonkeeper from police intimidation: "An intimation that it would be to his interest so support this or that candidate for prosecuting attorney or chief of police no longer has any weight with him. He obeys the law and has nothing to fear from the officials whose duty it is to enforce the law." 134 While these assertions closely followed the USBA script, they also echoed the opinion of some West Virginians who wanted to clean up the saloon business but did not necessarily want to eliminate the trade. Higher license fees and Sunday closing laws did little to limit the trade in Wheeling. While these legislative actions caused some ownership turnover among the Northern Panhandle city's bars, there was nearly the same number of saloons in 1912 (114) as in $1900(115) .{ }^{135}$

The ASL, of course, had very little interest in the suffering of any number of Mountain State taverns, no matter how pristine they were. As the 1909 regular session approached, the West Virginia League changed leadership. Alvord resigned his position and Reverend T.M. Hare, who "had twelve years' successful experience in Ohio, Wisconsin, and the District of Columbia," took over. In the American Issue, the ASL announced its interest in constitutional

\footnotetext{
${ }^{134}$ Wheeling Register, March 5, 1908.

${ }^{135}$ West Virginia Gazetteer and Business Directory, 1900-1901, Volume VII (Detroit: RL Polk and Company, 1900), 834-835; West Virginia Gazetteer and Business Directory, 1912-1913, Volume XIII (Detroit: RL Polk and Company, 1912), 1094-1095.
} 
prohibition and a county-level local option bill. ${ }^{136}$ This shift from the amendment-or-bust approach embodied by President Alvord to a more deliberate strategy did not appear only in the Mountain State. The League's 1909 Yearbook urged ASL members to be rational and patient in their anti-saloon agitation: "The league has always insisted that the temperance people everywhere should take conditions, not as they ought to be, but as they are; should consider public sentiment, not as they would like it, but as it is." To the League brass in 1909, this usually meant local option. Of course, the ASL was careful to remind its rank and file that "the first and last business of the Anti-Saloon League is to abolish saloons" by any feasible means. ${ }^{137}$ The USBA picked up on the League's local option strategy. According to its 1909 Yearbook, "Attempts at further restriction of the liquor traffic are for the most part likely to be in the direction of county local option. The ultimate aim of extremists is . . state-wide prohibition, but in lieu of it, or rather as a step toward it, county local option is occupying their immediate attention."138

Political and social developments external to the ASL and USBA appeared to have prepared a much more fertile field for West Virginia drys as the 1909 legislative session neared. The ME Church announced at its annual session that "the rising tide of temperance is a fact for encouragement and a forecast of still greater results yet to be achieved. The education of the children and youth, the crusade of the WCTU, and the recent organizing efforts of the ASL have

\footnotetext{
${ }^{136}$ American Issue (National Edition), February 1909, 11-12.

${ }^{137}$ Cherrington, The ASL Year Book, 1909, 168-171.

${ }^{138}$ Year Book of the USBA, 1909, 49.
} 
been most effective in crystallizing and shaping this sentiment." ${ }^{\text {139 }}$ Positive developments extended beyond conference resolutions. The West Virginia GOP crafted a platform that "called for the passage of a local option law and the submission of a state prohibition amendment to the people" in the summer of 1908. Republican gubernatorial candidate William E. Glasscock complied with his party's platform by supporting county local option and prohibition at the opening speech of his 1908 campaign. Lame-duck Governor Dawson "delivered a broad, reform-minded message to the [1909] legislature. He asked for a local option bill and the submission of a state prohibition amendment." ${ }^{\text {140 }}$ Dawson also included a call for statutory prohibition. According to the outgoing chief executive, "if the amendment fails of adoption by the Legislature the promise made to the people can be substantially carried out by a statute."141

All three anti-liquor approaches - constitutional prohibition, local option, and prohibition by statute - were on the legislative table during the 1909 session. Unfortunately for the ASL and its dry allies, not one passed. The House of Delegates passed the constitutional resolution sixtytwo to thirteen. However, the bill received sixteen affirmative and fourteen negative votes in the state senate, well short of the two-thirds majority it required. ${ }^{142}$ The Wheeling Register, one of the state's leading Democratic organs, took the opportunity to assail the majority Republican senators for violating the prohibitionist promises made in their party's platform. ${ }^{143}$ The

\footnotetext{
${ }^{139}$ Official Journal and Minutes of the West Virginia Conference of the Methodist Episcopal Church, Sixty-third Annual Session held at Mannington, WV from September the twenty-ninth to the fourth of October, 1909 (Published by the Secretaries, c. 1909), 87-88.

${ }^{140}$ Gary J. Tucker, "William E. Glasscock: Thirteenth Governor of West Virginia" (PhD diss., West Virginia University, 1978), 26, 29, 43.

${ }^{141}$ Regular Biennial Message of Governor Dawson to the Legislature of 1909 (Charleston, WV: News Mail, n.d.), 57.

${ }^{142}$ American Issue (West Virginia Edition), February 21, 1910, 2, and February 7, 1910, 3.

${ }^{143}$ Wheeling Sunday Register, February 21, 1909.
} 
Intelligencer denied the Register's claim. Pointing out that "fifteen republicans and one democrat voted for the amendment; nine republicans and five democrats voted against it," the GOP paper maintained that "this division of the parties in the state senate pretty closely represents the sentiment of the masses of the voters in the two parties on this question." The editors went on to assert "that the effort to make a party and political question out of prohibition has been a failure." 144

The Intelligencer's partisan defense may have been correct. Party affiliation did not (and never did) necessarily guarantee a particular position on statewide prohibition. Rather, the liquor status of one's home county and where that county was located probably had more to do with pushing legislators in one direction or another. Of the twenty-seven anti-amendment delegates and senators, twenty-two hailed from at least partially wet counties and nineteen represented border counties. ${ }^{145}$ Border-county representatives were perhaps more acutely aware of the challenges that would be faced by their constituency under statewide prohibition given the fact that five wet states surrounded West Virginia around the turn of the century. Senators and delegates from wet counties undoubtedly faced pressure from their constituents. State senators probably dealt with even more pressure as district conventions nominated them. According to Henry D. Hatfield from McDowell County, "In 1909 I voted against the submission of an amendment to be voted upon by the people to determine this [prohibition]. I did so under specific instructions from the Convention that nominated the Senator from my district." ${ }^{146}$

\footnotetext{
${ }^{144}$ Wheeling Intelligencer, February 22, 1909.

${ }^{145}$ American Issue (West Virginia Edition), February 21, 1910, 2, and February 7, 1910, 3; Cherrington, The ASL Year Book, 1909, 58; Dillon, West Virginia Blue Book, 1976, 280-285 and 290-310. With the exception of four, the wet counties were along West Virginia's periphery, in the southern coal fields, or in one of the panhandles.

${ }^{146}$ Quoted in Lockard, “The Temperance Movement," 29; Dillon, West Virginia Blue Book, 1976, 280-285, and 290310.
} 
A local option bill supported by the ASL also failed in the Senate, voted down fourteen to thirteen. ${ }^{147}$ This failure occurred in spite of the fact that Governor Glasscock, who had already publically supported such a measure, indicated his support for local option in an exchange with State Senator Henry Zilliken from Wellsburg. The senator expressed his opposition to prohibition and county-level local option and registered his concern that rural portions of particular counties would be able to dictate prohibition policy to the cities. According to Zilliken, "I wanted all cities, of say 2000 or may be 3000, exempted from any county option, considering that they should have a right to govern themselves." ${ }^{148}$ Governor Glasscock did not feel the same way. Responding a few days later, he told Zilliken that he did not agree but that he did admire his consistency. ${ }^{149}$ Ellis Yost authored a bill providing for statutory (legally codified) prohibition. Yost attempted to push his measure to the fore via unanimous consent immediately after the Senate rejected constitutional prohibition. Unfortunately for the dry delegate, Ohio County representative Buchwald objected, and statutory prohibition suffered the same fate as the other anti-liquor measures. ${ }^{150}$

Wheeling saloon owners were undoubtedly pleased that constitutional prohibition failed in the upper chamber. Liquor interests "were naturally rejoicing over the action of the senate, but voiced the opinion that, at an early date, there should be a high license law, applying to the entire state." This opinion was based on the increasingly popular wet assumption that such a measure "would ... tend to weed out the undesirable in the retail business, and place it in the

\footnotetext{
${ }^{147}$ American Issue (West Virginia Edition), February 7, 1910, 3.

${ }^{148}$ Zilliken to Glasscock, March 10, 1909, William Glasscock Papers, Box 2, West Virginia and Regional History Collection, West Virginia University, Morgantown, WV.

${ }^{149}$ Glasscock to Zilliken, March 13, 1909.

${ }^{150}$ Wheeling Sunday Register, February 21, 1909.
} 
hands of responsible parties." ${ }^{\prime 151}$ The 1909 legislature proved far more amenable to the wishes of the alcohol industry than those of the dry movement when it passed Henry Hatfield's high license bill. This measure increased the statewide liquor fee to $\$ 1,000$. While the editors of the Intelligencer called for the passage of a supplementary local option law (certainly not the ASL's preferred bill), they were convinced that the Hatfield bill was "along practical lines and to a limited degree embodies the idea of high license and strict legislation that have been found the most effective in controlling the liquor traffic." 152 More importantly, the Republican daily asserted that wets had already met Mountain State drys more than halfway on the liquor issue over "the past six years." According to the Intelligencer, "every enactment relative to the sale of liquors in this state has been distinctly towards regulation and limitation. These enactments may not have been as sweeping and drastic as a great many radicals would like to have them. Nevertheless they represent the sentiments of the very large majority of conservative people."153 As the March edition of the American Issue indicated, the national ASL did not agree with the Intelligencer on the extent of West Virginia prohibitionist sentiment. According to the monthly, "It remains true that there is no state in the Union where there is such intense temperance sentiment as in the 'Little Mountain State.' The violation of the platform pledges ... and the high-handed action by a few senators has put the people of the state into a good fighting mood." This mood, according to League journalists, would sweep out of office any wet senators up for reelection. ${ }^{154}$ Of course, ASL activists again charged the West Virginia liquor lobby with

\footnotetext{
${ }^{151}$ Wheeling Sunday Register, February 21, 1909.

152 Wheeling Intelligencer, February 25, 1909; the ASL discussed the legislative competition between their local option measure and "a whiskey local option bill" in American Issue (National Edition), March 1909, 13.

${ }^{153}$ Wheeling Intelligencer, February 25, 1909.

${ }^{154}$ American Issue (National Edition), March 1909, 13-14.
} 
corruption and vote buying. Alvord, acting as the League's legislative agent, alleged in a Huntington newspaper interview "that a sum of one million dollars would be raised if necessary by the liquor interests to defeat prohibition and asserting that $\$ 110,000$ was spent to beat it last year in the senate." One senator was so incensed by the former ASL chief's charges that he demanded Alvord's expulsion from the chamber if he could not prove his allegations. ${ }^{155}$ The American Issue reported on this incident, and, perhaps not surprisingly, backed Alvord's charges as much as they could. League newsmen maintained that a senate investigation proved that alcohol agents collected a prohibition defense fund and that "one senator did testify that the liquor interests approached him through a close friend" to buy his negative vote - an offer he did not accept. The ASL did, however, have to admit that investigators "failed to find any direct evidence showing that any member of the senate had accepted money to influence his vote."156

The League's corruption charges were not entirely out of the ordinary for the time period. After all, turn-of-the-century social critics argued that the American saloon "ignored the law, corrupted the police, the courts, and the politicians. It was a breeding place of crime and violence, and the hangouts of criminals and degenerates of every type." ${ }^{157}$ The West Virginia ASL accounted for the repeated failures of its measures in the state senate by reminding supporters that upper house members served four-year terms, "and consequently do not have their records passed upon by the people as frequently as the members of the lower house." Of course, the senate also included fewer legislators, and this situation, according to the League, bred corruption: "The smallness of the body makes it easier to control by methods commonly

\footnotetext{
${ }^{155}$ Wheeling Intelligencer, February 3, 1909.

${ }^{156}$ American Issue (National Edition), March 1909, 13.

${ }^{157}$ Herbert Asbury, quoted in Engelmann, Intemperance, 8.
} 
used by the traffic." 158 The key to changing its fortunes in the state senate was, as the League saw it, to change the upper chamber's composition. Consequently, the Mountain State League published a full record of the senators' votes on constitutional prohibition and the ASL local option bill during the 1909 session by county and district and whether or not these senators were up for reelection. League journalists also reminded their supporters that "unless you are positively sure the candidates will support the legislation sought, you should not only refuse him your support, but should do all in your power to secure his defeat."159

In early 1910, the West Virginia ASL offered another avenue for bypassing the seemingly intransigent state senate. Obviously frustrated by its repeated failures in the upper chamber, the League decided to focus its support on a prohibition statute during the 1911 legislative session. According to the American Issue, "We are for the statute rather than the amendment, because it is possible, in our judgment, to secure the statute and very doubtful whether the amendment would pass the senate at the next session. The policy of the League has always been to accept a fighting chance as against a chance to fight." ${ }^{\prime 160}$ This declaration closely mirrored the patient and rational approach suggested by the ASL in 1909. A few months later, the West Virginia League reiterated the benefits of prohibition by statute. As the editors of the American Issue reasoned, "Statutory prohibition is the logical measure to be fought for in this state. First: Because the state is ready for prohibition. ... Second: It is as effective as an amendment, and is easier to get. ... Third: It could not be repealed. . . Fourth: It is effective

\footnotetext{
${ }^{158}$ American Issue (West Virginia Edition), February 7, 1910, 3.

${ }^{159}$ American Issue (West Virginia Edition), February 7, 1910, 3.

${ }^{160}$ American Issue (West Virginia Edition), March 21, 1910, 4.
} 
immediately. ... Fifth: It will eventuate in an amendment." ${ }^{\text {161 }}$ USBA leaders, on the other hand, still considered local option measures the main legislative threat to the alcohol industry. The 1910 USBA Yearbook contended that "local option is certain to remain a constant principle in liquor legislation, and it is being used more and more as the means whereby to make 'dry,' or as dry as possible, States in which general prohibition seems unattainable at the present time." Ultimately, the 1911 session in Charleston would prove the ASL's legislative strategy misguided, and the USBA's local option assumption fatally wrong. While West Virginia was one of five states to reject prohibition in its upper chamber in 1909, the situation in 1911 proved to be more amenable to constitutional prohibition. ${ }^{163}$ More and more counties had elected to go dry as teetotaler momentum continued to grow. By 1910, thirty-seven counties were dry and three more climbed on the water wagon the next year. ${ }^{164}$ In addition to the fact that a majority of citizens in nearly 73 percent of West Virginia's counties had voted to elect anti-liquor officials by 1911, Mountain State drys also stood ready to exploit a significant turnover in the state senate. Of the fourteen senators who voted against constitutional prohibition in 1909, six did not return in $1911 .{ }^{165}$ While it is impossible to determine if the six lost reelection strictly because of an anti-saloon backlash, new senators certainly meant new opportunities for dry political agents.

\footnotetext{
${ }^{161}$ American Issue (West Virginia Edition), September 5, 1910, 1.

162 Year Book of the United States Brewers' Association (New York: United States Brewers' Association Publishers, 1910), 13.

${ }^{163}$ Ernest H. Cherrington, ed., The ASL Yearbook: An Encyclopedia of Facts and Figures Dealing with the Liquor Traffic and the Temperance Reform, Volume 3 (1910) (Westerville, OH: American Issue Publishing, n.d.), 233.

${ }^{164}$ Cherrington, The ASL Yearbook, 1910, 83; Ernest H. Cherrington, ed., The ASL Yearbook: An Encyclopedia of Facts and Figures Dealing with the Liquor Traffic and the Temperance Reform, Volume 4 (1911) (Westerville, OH: American Issue Publishing, n.d.), 79.

${ }^{165}$ American Issue (West Virginia Edition), February 7, 1910, 3, and February 20, 1911, 2.
} 
Executive support also appeared to be quite an important factor in the eventual victory of constitutional prohibition during the 1911 session. Governor Glasscock, who had supported prohibition and local option during the 1910 campaign, reassured his dry supporters at the opening of the legislature. He used part of his biennial address to remind legislators that both parties had backed the submission of a prohibitionist constitutional amendment in their respective 1908 platforms. Glasscock argued that because "of these declarations ... I am persuaded to believe that you will take favorable action on the resolution which will doubtless be submitted to you." In addition, the governor endorsed a county-level local option measure. ${ }^{166}$ Governor Glasscock probably mentioned the fact that both Democrats and Republicans came out in favor of submission because he faced a split legislature for the first time in several years. While the GOP had enjoyed heavy majorities in both chambers since the turn of the century, Democrats and Republicans were equally split in the senate, and Democrats enjoyed a huge advantage in the house after the 1910 election. ${ }^{167}$ The West Virginia ASL, of course, credited the dry movement for this party flip. According to the League, the GOP lost control because it did not pass prohibition: "The Republican party failed to make their promises good. The result of this betrayal of the trust of the people is seen in the last election. For the first time in years the state went strongly Democratic. Out of the fifteen senators elected at the last election, four only were Republicans." 168 The prohibition question did, along with intra-party bickering, cause fractures in the GOP during the election of 1910. For example, wet Democrats and Republicans in Mason County united against dry campaigners, and teetotalers backed a dry Democratic

\footnotetext{
${ }^{166}$ Regular Biennial Message of Governor Glasscock to the Legislature of 1911 Regular Session (Charleston, WV: New-Mail Company, 1911), 43-46.

${ }^{167}$ Dillon, West Virginia Blue Book, 1976, 321.

${ }^{168}$ American Issue (West Virginia Edition), February 6, 1911, 3.
} 
congressional candidate. One political observer "related to the Governor that he "failed to discover a bit of the old time loyalty among the leaders in Mason County.',169

On the eve of the 1911 session, the Mountain State ASL advised its members in the American Issue of the prohibitionist measures on the docket. According to the League, these bills included an amendment for statewide prohibition and a measure authorizing county-level local option. ASL leaders saw local option as an important insurance policy: "That the liquor traffic may be brought under stricter regulation while the amendment, if submitted, is pending, a county local option law should be passed to go into effect at once." Because "more than sixty thousand names signed to [pro-amendment] petitions" did not sway the state senate in 1909, the League urged its members to write personal letters to their senators and delegates asking for affirmative votes on local option and constitutional prohibition and even included a full roster of legislators in the January 9 American Issue. ${ }^{170}$ It is important to note that the ASL focused mainly on constitutional prohibition and local option in early 1911. In fact, the League's 1911 Yearbook honed in on a prohibition amendment in West Virginia. According to the editors, "The fight is on for a constitutional prohibitory amendment which will be the [their emphasis] issue before the legislature of 1911."171 Statutory prohibition, which had been the League's avowed preference as late as the fall of 1910, had virtually disappeared as a legislative goal by the beginning of 1911. While the Mountain State ASL still retained local option as a gradualist alternative, they mainly considered it a regulatory stop-gap until statewide prohibition, if passed,

\footnotetext{
${ }^{169}$ Tucker, “William E. Glasscock,” 104-106; Adjutant General Elliott, quoted in ibid., 106.

${ }^{170}$ American Issue, (West Virginia Edition), January 9, 1911, 3-4.

${ }^{171}$ Cherrington, The ASL Yearbook, 1911, 80.
} 
went into effect. West Virginia drys were, once again, prepared to fight for their ultimate goal in Charleston.

President Hare seemed confident that his organization's ultimate goal would finally be achieved in 1911. The president "had no doubt that the prohibition amendment will be submitted. . . Dr. Hare says that the prohibition amendment will have 63 of the 86 votes in the House and 22 of the 30 in the Senate." ${ }^{\prime 72}$ Even Hare could not have predicted the tsunami of support enjoyed by the prohibition resolution. On February 3, the House of Delegates passed its prohibition measure seventy-three to nine. ${ }^{173}$ Four days later, the senate passed its own version by an overwhelming twenty-three to seven vote. According to the Intelligencer, anti-dry sentiment dwindled at the last minute as "at noon to-day it was reported that at least ten would be cast against the measure in the Senate. Unable to get the eleventh vote [which would have killed the bill], it is said, three voted against the drys." When the senate announced the margin, "hundreds of men and women who had gathered in the Senate chamber and in the galleries broke forth in cheers." 174 A small cadre of anti-amendment legislators stayed solid even as certain defeat approached. Of the eight senators who voted against prohibition in 1909 and remained in 1911, six still rejected the senate resolution. Of these six, five hailed from border counties. ${ }^{175}$ On February 9, the house considered the state senate's resolution, which went into effect on July 1,1914 , instead of in 1913. Delegates authorized the measure seventy-two to ten. ${ }^{176}$

\footnotetext{
${ }^{172}$ Wheeling Intelligencer, January 17, 1911.

${ }^{173}$ Charleston Mail, February 3, 1911.

${ }^{174}$ Wheeling Intelligencer, February 8, 1911.

${ }^{175}$ American Issue (West Virginia Edition), February 7, 1910, 3, and February 20, 1911, 2; Dillon, West Virginia Blue Book, 1976, 280-285 and 290-310.

${ }^{176}$ Charleston Mail, February 9, 1911.
} 
West Virginia citizens would vote on the submitted prohibitory amendment during the election of 1912. This would be the second time in 24 years that the general population would have the right to consider statewide prohibition. The measure read:

On and after the first day of July, one thousand nine hundred and fourteen, the manufacture, sale and keeping for sale of malt, vinous or spirituous liquors, wine, ale, porter, beer or any intoxicating drink, mixture or preparation of like nature, except as hereinafter provided, are hereby prohibited in this state. Provided, however, that the manufacture and sale and keeping for sale of such liquors for medicinal, pharmaceutical, mechanical, sacramental, and scientific purposes, and the manufacture and sale of denatured alcohol for industrial purposes may be permitted under such regulations as the legislature may prescribe. The legislature shall, without delay, enact such laws, with regulations, conditions, securities and penalties as may be necessary to carry into effect the provisions of this section. ${ }^{177}$

With less than two years before the 1912 general election, Mountain State wets and drys scrambled to array their allies and discipline their messages. What occurred over the next twenty-one months, especially in 1912, was a massive public relations campaign the likes of which had never been seen in West Virginia. The state prohibition race looked much like the special interest campaigns of today as each side organized into focused front groups or alliances, utilized prominent speakers, disseminated propaganda via the mass media, and invested significant resources in an attempt to secure victory.

Key to the dry campaign was the organization of the movement's disparate interests.

With numerous groups supporting the same thing, it was important to fuse this pro-amendment sentiment into one, streamlined pressure group. This process was made considerably easier by the fact that many of the state's most influential anti-liquor churches had already aligned themselves, at least unofficially, with temperance groups like the ASL. At their annual

${ }^{177}$ Quoted in Lockard, "The Temperance Movement," 30. 
conference in the fall of 1911, Mountain State Methodists praised the dry campaign's organizational plans. Temperance committee members resolved "that we commend the Temperance Society of the Methodist Episcopal Church, and that we most heartily endorse the action of the Anti-Saloon League, WCTU, and member of the Prohibition party in federating their forces in promoting the ratification of the Prohibition amendment."178 A few months later, the most influential personalities in the West Virginia prohibition movement met in Clarksburg and created the State Ratification Federation of West Virginia. This organization was a veritable who's who of Mountain State dryness. Among many others, WCTU head Lenna Yost, dry activist Judge J.C. McWhorter, and ASL superintendent T.M. Hare were assigned specific duties within the group's efforts. Hare became campaign manager and district organizations radiated all the way down to the county and local levels. One member of the Federation boasted that "the result was that the drys had a better organization than either the Republican or Democratic parties even. ... The machine worked like a clock."179

Elements of the Mountain State's wet industry cobbled together a response to the antisaloon campaign's organizational efforts. Their primary advocate took the form of a USBA and liquor interest-funded front organization called the "Taxpayers' Protective Association."180 This group operated out of the Wheeling's Schmulbach Building (owned by one of the city's largest brewing companies). According to the ASL, "The purpose of their disguise is to deceive the

\footnotetext{
${ }^{178}$ Official Journal and Minutes of the West Virginia Conference of the Methodist Episcopal Church, Sixty-fifth Annual Session, Held at Charleston, WV from October the fourth to October ninth, 1911 (Published by the Secretaries, c. 1911), 89.

${ }^{179}$ American Issue (National Edition), January 1913, 5, 10.

${ }^{180}$ American Issue (West Virginia Edition), September 16, 1912, 3.
} 
voters of West Virginia."181 The Association commissioned scores of anti-amendment advertisements in newspapers throughout West Virginia. Among other things, these messages announced upcoming wet speakers, attacked the overambitious breadth of the pending amendment, and attempted to undermine many of the dry campaign's more influential arguments. $^{182}$ Editors at some Mountain State newspapers also presented statements against state prohibition. As had been the case since the beginning of the wet reaction to the prohibitionist impulse, these contentions often times revolved around the potential economic dangers associated with the proscription of legal liquor sales. Editors at the Intelligencer asserted that the state, counties, and cities derived $\$ 1,250,000$ from the license system on an annual basis and that "every voter in this state on the average will pay at least $\$ 5.00$ per year in increased direct taxes for the privilege of helping write prohibition of liquor into the State Constitution." Additionally, they worried that the authorization of statewide prohibition would “force upon communities like Wheeling, Parkersburg, Huntington, Charleston, Bluefield and other, a condition of affairs which is repugnant to the majority of their citizens.",183

Of course, the Ratification Federation had an answer for all of the Protective Association's arguments. They funded their own newspaper messages. These included advertisements entitled "Wheeling Lost a Million Dollars Payroll Because She Had Saloons" and axioms like "economy in municipal government with the saloon is impossible." 184 The Federation extended its campaign far beyond the confines of the West Virginia press. Lenna Yost handled temperance literature and propaganda and G.I. Wilson, leader of the Presbyterian

\footnotetext{
${ }^{181}$ American Issue (West Virginia Edition), August 5, 1912, 3.

${ }^{182}$ Parkersburg Sentinel, October 22, 1912; Wheeling Intelligencer, October 28, 1912 and October $29,1912$.

${ }^{183}$ Wheeling Intelligencer, October 12, 1912.

${ }^{184}$ Wheeling Intelligencer, October 31, 1912 and November 2, 1912.
} 
Temperance Society in the Mountain State, was in charge of the public speaking wing. He coordinated "something like 500" speakers during the election. Additionally, according to the American Issue, "The Anti-Saloon League contributed admirably to the speaking campaign, many of the states sending their strongest men to our assistance."185 One of the most influential speakers was Christian firebrand Billy Sunday. He toured the state, delivering pro-amendment speeches in a train rented by the national League. ${ }^{186}$

On the day of the election, West Virginia drys ran an advertisement imploring citizens to "remember God goes into the election booth with you. Vote a ticket that will honor Him." 187 The voters complied. After sixty years of trying, Mountain State teetotalers had finally convinced a majority of the state that prohibition was indeed a noble experiment. The referendum passed by a vote of 164,945 to 72,603 . Only Ohio County, McDowell County and diminutive Hardy County rejected statewide prohibition. ${ }^{188}$ It would be an understatement to contend that Ohio and McDowell were still wet as the referendum approached. They were two of the few wet counties left in 1911, and eight of the eighteen total delegates and senators who rejected the prohibition resolution hailed from these two locales alone. ${ }^{189}$ The aggressiveness and passion of the dry ground forces undoubtedly contributed to the overwhelming prohibitionist majority at the polls. According to Lockard, "So intense was the effort of the temperance forces that in most counties no voter went to the polls without being interviewed personally several

\footnotetext{
${ }^{185}$ American Issue (West Virginia Edition), November 11, 1912, 3.

${ }^{186}$ Szymanski, Pathways to Prohibition, 158-159.

${ }^{187}$ Wheeling Intelligencer, November 5, 1911.

${ }^{188}$ Harris, West Virginia Legislative Handbook, 722.

${ }^{189}$ Cherrington, The ASL Yearbook, 1911, 79; American Issue (West Virginia Edition), February 20, $1911,2$.
} 
times."190 These same activists also made sure that wet agents did not corrupt the election or buy poll workers. Worried that national alcohol interests had raised " $\$ 800,000$ for the purpose of buying the election," teetotalers stalked anti-amendment "fixers" from the moment they arrived at the polls. ${ }^{191}$

The outcome of the 1912 referendum campaign was the complete opposite of the 1888 vote on statewide prohibition. It is important to remember, however, that there existed some coordination of dry forces in 1888. In fact, discussing national trends, Szymanksi argues that "prohibition associations from both periods managed to effectively combine the resources of their various constituent groups to create elaborate referendum campaigns." Therefore, according to the historian, "the greater success of the Progressive Era campaigns compared to those of the 1880s cannot be due to the development of innovative organizing techniques after 1900." She asserts, then, that the post-1900 shift in the temperance movement away from "a maximalist strategy" towards local gradualism was the key factor as it attracted more citizens willing to support statewide prohibition. ${ }^{192}$ In the case of the West Virginia dry movement, Szymanski is partially correct. The increasing discipline and sophistication exhibited by Mountain State teetotalers after the turn of the century, the development of statutory gradualism, and the rise of the ASL and its adherence to a more patient approach to anti-liquor agitation did indeed move the cause forward. Additionally, there was an attempt in 1888 "to coordinate the

\footnotetext{
190 Lockard, "The Temperance Movement," 31.

191 Morgantown Post-Chronicle, October 30, 1912; American Issue (National Edition), January $1913,10$.

192 Szymanski, Pathways to Prohibition, 156, 162.
} 
various factions and lead them to victory.” However, these efforts, led by Parkersburg's Dave Johnson were largely unsuccessful. ${ }^{193}$

Not only was this attempted coalition unsuccessful, it also lacked the cohesion and cooperation exhibited by the State Ratification Federation in 1912. Organizational success and the development of new strategies are not enough to explain the ultimate political victory of statewide prohibition in the Mountain State. Social, political, and demographic forces and changes both inside and outside the state also transformed the very nature of government and what it meant to be a citizen. In 1888 , most West Virginians simply discounted the idea that they had the right to control the habits of their neighbors, and so did their elected officials. As the early 1900s dawned, however, this laissez-faire assumption changed. Industrialization, immigration, and the rise of a slightly more Progressive Republican Party power structure convinced more and more Mountain State residents that strictly controlling, and eventually abolishing, the alcohol trade was a preferable and even necessary policy. West Virginia prohibitionists in 1912, however, scarcely cared about why they had won. The bottom line to them was that they had gotten what they wanted. Now they would have to make their dry mountain paradise work.

${ }^{193}$ Lockard, "The Temperance Movement," 23-24. 
CHAPTER FIVE: One Step Forward, Two Steps Back: The Crisis of Enforcement and the Death of West Virginia State Prohibition, 1913-1934

\begin{abstract}
I care not what your individual opinion of the law may be, you cannot say that intoxicating liquor has ever benefitted anyone in a substantial way, except in those who traffic in it. It is a law and it is not a matter of whether we are personally in favor of it or against

it - it must be enforced. It is said that it interferes with our personal liberty - but bear in mind that there is no such thing as personal liberty. Liberty consists in doing such things as may suit our own convenience so long as it does not interfere with the rights of another or with the public. ${ }^{1}$
\end{abstract}

The 1913 session of the West Virginia Legislature convened in the midst of considerable domestic upheaval just outside the Mountain State's capitol city. Paint Creek and Cabin Creek witnessed brutal conflicts between striking miners and their company bosses over organization rights and the infamous mine guard system. ${ }^{2}$ Not surprisingly, the strikes dominated the front pages of many of West Virginia's newspapers in late 1912 and early 1913. While certainly not entirely ignored, the legislative battle over the state prohibition enforcement law played second fiddle in the minds of many Mountain State residents. In the long run, however, the resulting enforcement mechanism - and all its inherent shortcomings - would wreck almost as much social, political, and economic havoc on West Virginia as the Paint Creek strikes. Governor William Glasscock pushed for a strict bill in his final message to the legislature. Glasscock

\footnotetext{
${ }^{1}$ West Virginia Judge instructing a grand jury, quoted in Annual Report from State Commissioner of Prohibition for Fiscal Years 1922-1923, 9, in E.F. Morgan Papers, Box 29, West Virginia and Regional History Collection, West Virginia University, Morgantown, WV.

${ }^{2}$ Otis Rice and Stephen Brown, West Virginia: a History, $2^{\text {nd }}$ ed. (Lexington: University Press of Kentucky, 1993), 224-226.
} 
reminded the solons that "the vote showed that an overwhelming majority of people are opposed to ... intoxicating liquors, and I take it that you will pass laws that will reflect the sentiment of the voters." The Republican governor went on to maintain that "I think your laws on this subject should be as stringent as possible and means provided for the enforcement thereof."

Prohibitionist legislators and their dry allies quickly got to work on an enforcement measure. According to E. Kidd Lockard, "[Prohibition groups] had a free hand in the enactment of the enabling law necessitated by the amended Constitution." ${ }^{4}$ Similar to their ad hoc coalition during the 1912 referendum effort, political, social, and legal leaders demonstrated impressive coordination in Charleston at the beginning of the 1913 legislative session. Prohibitionist senators and delegates, legal leaders, and the head of the Anti Saloon League (ASL) were all present in the room to draft the enacting law. As Circuit Court Judge and ratification federation leader J.C. McWhorter recounted, "[The group] was assigned the task of drafting the entire prohibition statute ... known as the Yost Law. A room with stenographers was assigned to me for that purpose in the capitol building. I remained there for nearly two weeks until the work was complete and had received the approval of the Legislature." bragged about the proposed legislation's stringency. According to the group, the Yost Law "will, if enacted into law, make West Virginia the dryest [sic] state in the union."

The resulting measure (House Bill Number Eight), in spite of its strictness, faced only token opposition in the house and senate. Delegates Weiss and Scherr from Ohio and Kanawha

\footnotetext{
${ }^{3}$ Regular Biennial Message of Governor Glasscock to the Legislature of 1913, January 2, 1913 (Charleston, WV: Union Printing, 1912), 29.

${ }^{4}$ E. Kidd Lockard, "The Temperance Movement in West Virginia" (MA thesis, West Virginia University, 1937), 39.

${ }^{5}$ McWhorter, Quoted in Lockard, “The Temperance Movement," 39.

${ }^{6}$ American Issue (West Virginia Edition), January 20, 1913, 3.
} 
Counties attempted "to break down the barriers against the use of liquor in private clubs and to increase the lawful percentage of alcohol in what are known as non-intoxicating liquors." Their efforts were unsuccessful. ${ }^{7}$ The House of Delegates passed the Yost Law seventy-two to zero on February $11{ }^{8}$ Two days later, the vote in the upper house was nearly unanimous as well. Senators passed the bill twenty-four to one, with only Senator Strother from McDowell County casting a negative vote. ${ }^{9}$ Dry leaders were relatively pleased that state solons passed the Yost Law with relatively few adjustments. According to Judge McWhorter, "The act as drafted by me was passed in its entirety with the exception of some slight amendments." ${ }^{10}$ The new law read:

An act to prohibit the manufacture, sale and keeping for sale of malt, vinous or spirituous liquors, wine, porter, ale, beer or any intoxicating drink, mixture or preparation of like nature, except the manufacture, sale and keeping for sale of medicinal, pharmaceutical, mechanical, sacramental or scientific purposes, and the manufacture and sale of denatured alcohol for industrial purposes as regulated and provided for by this act; and to enforce the amendment of section, forty-six of article six of the state constitution, ratified on the fifth day of November, one thousand nine hundred and twelve; and making the state tax commissioner ex officio state commissioner of prohibition, and defining his duties; and providing for the enforcement of this act and prescribing penalties for violations thereof. ${ }^{11}$

In spite of its nearly unanimous legislative support, not everyone was pleased with the state prohibition law. As the senate vote neared, the Wheeling Register, a long-time and

\footnotetext{
${ }^{7}$ Wheeling Intelligencer, February 8, 1913.

${ }^{8}$ Journal of the House of Delegates of the State of West Virginia for the Extraordinary Session of 1913 and the Thirty-first Regular Session, Commencing January 8, 1913 (Charleston, WV: Tribune Printing Company, 1913), 510.

${ }^{9}$ Journal of the Senate of the State of West Virginia for the Extraordinary Session, Commencing January 2, 1913 and the Thirty-first Regular Session, Commencing January 8, 1913 (Charleston, WV: Tribune Printing Company, 1913), 506.

${ }^{10}$ McWhorter, Quoted in Lockard, “The Temperance Movement," 39.

${ }^{11}$ Acts of the Legislature of West Virginia, Thirty-first Regular Session, 1913. Accessed on www.wvculture.org (July $25,2008)$.
} 
outspoken opponent of liquor proscription, dusted off familiar wet arguments in its February 11 edition. According to the editors, "A measure which is unwise and impractical in most of its provisions, which contemplates a glaring infringement of the rights and liberties of the people, and if enacted would do irreparable damage to the state is the Yost bill."12 The United States Brewers Association (USBA), a major factor in the fight against state prohibition during the 1912 referendum campaign, warned Mountain State residents that the Yost Law threatened more than just their civil liberties. USBA activists actually agreed with their dry enemies when they acknowledged that "the West Virginia prohibition law . . . is the most drastic that has been written in the statutes of any state." Of course, "the people of West Virginia will, however, have to pay the fiddler for their folly. Governor Glasscock calls attention to the need for additional taxes to make up for the deficiency in public revenues that will follow the extinction of the licensed saloon." ${ }^{\prime 13}$ The Register and USBA had clearly resuscitated the same wet contentions that liquor proscription violated the personal liberty of citizens and retarded economic growth around the passage of the Yost Law as they did during the campaign of 1912.

These arguments had not convinced enough West Virginians in 1912 to stem the tide of statewide prohibition. By 1933, however, many of these same citizens voted 218,628 to 136,552 to name "twenty delegates to a special convention meeting in Charleston for the purpose of casting West Virginia's vote for the repeal of the Eighteenth Amendment."14 Mountain State

\footnotetext{
${ }^{12}$ Wheeling Register, February 11, 1913.

${ }^{13}$ United States Brewers' Association: The Yearbook and Proceedings of the $53^{\text {rd }}$ Annual Convention Held in Atlantic City, NJ, Friday and Saturday, October $3^{\text {rd }}$ and $4^{\text {th }}, 1913$ (New York: United States Brewers' Association Publishing, 1914), 252-253.

${ }^{14}$ Lockard, "The Temperance Movement," 43; New York Times, October 21, 1934.
} 
residents then repealed the state prohibition law by a majority of 40,000 votes the next year. ${ }^{15}$ Certainly, the shift from a progressive political and social worldview to one of normalcy between the teens and twenties and the eventual collapse of the nation's financial system in the late 1920s and early 1930s strengthened the libertarian and economically alarmist arguments of the wet phalanx in the minds of many West Virginians. Social transformations and macroeconomic distresses, however, were not enough to sour the majority of citizens against statewide liquor proscription. Mountain State residents eventually rejected the Yost Law for one key reason: it never worked.

There existed a fundamental disconnect between the law's intent and the way in which the authorities enforced it. West Virginia drys were not blind to the fact that passing a state liquor proscription law was one thing and enforcing it was another. On July 1, 1914, Morgantown Post-Chronicle editors acknowledged that "the fight to make West Virginia a dry state is not ended. The real battle has just begun. All the proceedings up to Tuesday night were merely preliminary. The actual warfare began today." ${ }^{16}$ Even the West Virginia ASL, still gloating over its defeat of the saloon industry, paid extensive lip service to the enforcement of their newly drafted enabling measure. In the June 9, 1913, printing of the American Issue, ASL leaders recognized that "constant vigilance will be necessary upon the part of the enemies of the saloon. . . . No law is self-enforcing. All the legislature has done in the case of the Yost law is to put adequate weapons in the hands of the men who want to see effective prohibition in the state." 17

\footnotetext{
${ }^{15}$ Lockard, "The Temperance Movement," 43; Huntington Herald-Dispatch, November 8, 1934.

${ }^{16}$ Quoted in Lockard, "The Temperance Movement," 40.

${ }^{17}$ American Issue (West Virginia Edition), June 9, 1913.
} 
There were indications on the eve of the new law's inception that state officials also took enforcement seriously and expected Mountain State citizens to do the same. Governor Henry Hatfield, for example, urged local cooperation and promised state support in the fight against illegal liquor on the eve of the law's implementation. According to the governor, "The state will stand ready at all times to give assistance to the local officials, but will expect the officers of the various districts and counties to take up the enforcement of the prohibition measure with sincerity of purpose."18 State Tax Commissioner Fred Blue, unofficial state prohibition commissioner and longtime dry agitator, left little doubt in the minds of Mountain State citizens that he would stringently enforce the law: "Prohibition will prohibit. It will be the policy of this office to enforce the law to the letter and we hope to have the co-operation of every state, county, and municipal official." ${ }^{\prime 19}$ Even the Wheeling Intelligencer, hardly a journalistic bastion of dryness, was forced to admit that the state had adequately prepared its citizens for the impending Yost Law. As the editors conceded, "The people of the State have been well prepared for the enforcement of its provisions . . a and no offender can plead ignorance of the law if caught up." 20 Shortly after July 1, 1914, the West Virginia ASL also disseminated 85,000 copies of state prohibition guides in twelve different languages to insure that the state's new immigrant groups would not be ignorant of the law. ${ }^{21}$

Beer brewers and liquor distillers were certainly not ignorant of state prohibition and its various requirements (and loopholes). The original Yost Law only banned "the manufacture, sale and keeping for sale of malt, vinous or spirituous liquors, wine, porter, ale, beer or any

\footnotetext{
${ }^{18}$ Quoted in McDowell Recorder, June 25, 1914.

${ }^{19}$ Quoted in Wheeling Intelligencer, July 1, 1914.

${ }^{20}$ Wheeling Intelligencer, June 29, 1914.

${ }^{21}$ American Issue (West Virginia Edition), August 3, 1914, 8.
} 
intoxicating drink, mixture or preparation of like nature." ${ }^{22}$ It did not outlaw the importation or consumption of alcohol. This meant that beer and liquor producers and dealers only needed to cross the border after July 1 into one of West Virginia's five wet neighbors to continue their trade. Several West Virginia breweries, distillers, and wholesalers sold alcohol to Mountain State customers via a cash on delivery (COD) system after the Yost Law began. Reymann Brewing Company, one of Wheeling's largest brewers, simply moved their excess stock to Mingo, Ohio "with the intention of reshipping it back to West Virginia when the state becomes 'dry." The Wheeling Register opined that "this innovation and foresight on the part of the local brewing company is expected to prove exceedingly popular." ${ }^{23}$ Some of the state's drier dailies, like the Morgantown Post-Chronicle, dutifully advertised non-alcoholic offerings. The editors, for example, accepted advertisements for "supremely satisfying ... thirst quenching ... delicious ... keen ... [and] wholesome" Coca-Cola. ${ }^{24}$ In the weeks leading up to state prohibition, however, advertisements for shipping houses and brewing companies littered the pages of many of the state's other papers. Of course, the Register and Intelligencer led this cavalcade of wet print. One Clarksburg distributor announced that "Davis Big Mail Order Whiskey House is now located at Oakland, Md." ${ }^{25}$ The Belmont Brewing Company ran an advertisement in the Register about a week before the Yost Law, reminding their customers that they "will be served upon bona fide orders for the personal use only, from the Belmont storage house at Mingo Junction, O. The law requires that they sign personally for it when delivered."26

\footnotetext{
${ }^{22}$ Acts of the Legislature, 1913.

${ }^{23}$ Wheeling Register, June 27, 1914.

${ }^{24}$ Morgantown Post-Chronicle, June 30, 1914.

${ }^{25}$ Wheeling Register, June 26, 1914.

${ }^{26}$ Wheeling Register, June 27, 1914.
} 
The early COD liquor trade in West Virginia was merely a preview of the legal complexity - and resulting wet/dry conflict - inherent in the state prohibition law. ASL activists and their dry allies who wrote the anti-liquor measure earnestly believed that they were making West Virginia a better place for its citizens. As Sean Cashman contends, however, their dry mountain paradise "was a victory of the beliefs of the nineteenth century over the needs of the twentieth." 27 As America drifted away from the tenants of progressivism after the Great War and political leaders and their constituents focused on other priorities, prohibition withered on the vine until national economic dislocations necessitated the liberalization and eventual removal of liquor proscription. West Virginians may have accepted the idea of ending the saloon trade via state prohibition, but "it was long evident to those engaged in executing the law that a large number of the state's citizens had little interest in strict enforcement."28 It was clear also that, although many political leaders may have believed in liquor proscription, they never chose to fund it adequately. Dry Federal legislators, for example, rarely obliged constant calls for higher levels of enforcement funding. According to Larry Engelmann, "Their counterparts in the state legislatures, on the other hand, actually outperformed them in prohibition penny-pinching, spending less for enforcement of the dry laws than they did to maintain their parks and public monuments." 29 This penny pinching extended to the Mountain State. Governor Henry Hatfield admitted in his 1915 address to the legislature, for example, that funding for prohibition enforcement was "meager."

\footnotetext{
${ }^{27}$ Sean Dennis Cashman, Prohibition: The Lie of the Land (New York: The Free Press, 1981), 25.

${ }^{28}$ Lockard, "The Temperance Movement," 43.

${ }^{29}$ Larry Engelmann, Intemperance: The Lost War Against Liquor (New York: The Free Press, 1979), 150.

${ }^{30}$ First Biennial Message of Governor Henry Hatfield to the 1915 Legislature (Charleston, WV: Tribune Printing, 1915), 42.
} 
Of course, the biggest weakness of state prohibition in West Virginia had less to do with shifting politics, an indifferent populace, and funding shortfalls and more to do with the fact that human beings drafted an imperfect law. Mountain State voters eventually rejected the Yost Law because it became increasingly clear to them that the measure itself was a farce. In 1914, the West Virginia state prohibition law was indeed among the most stringent in the nation. Dry activists and their political and legal allies realized this and did their best on the eve of the law's inception to prepare and inform West Virginians. What they were not prepared for, however, was the fact that the Mountain State itself, with its five bordering wet states and mountainous and sometimes remote interior, made enforcement an exceedingly difficult proposition. ${ }^{31}$ West Virginia, then, becomes an apt - if not a bit extreme - case study of why prohibition never worked. In short, Mountain State legislators and law enforcement officials faced the worst of both worlds - a strict law and an unforgiving setting.

The state legislature made repeated, earnest attempts to address weaknesses in the law and to tackle emerging crises in its administration during the 1910 s and 20s. In fact, "The Yost Law was strengthened by each legislature meeting before 1931 with the exception of the session held in 1925."32 While some of these biennial amendments were only minor in intent, what this constant legal fiddling suggests is that West Virginia politicians and law enforcement authorities fought a rear-guard action against the liquor industry and lawbreakers. Every time they plugged a leak or reinforced the dry dam, another hole appeared. In short, the state always took one step forward and two steps back in maintaining a dry society. This reactionary and defensive legal

\footnotetext{
${ }^{31}$ Prohibition Commissioner Blue commented on the presence of these wet neighbors in his first report. First Biennial Report of the State Tax Commissioner of West Virginia, Ex-Officio State Commissioner of Prohibition for the Fiscal Years 1915-1916, Fred O. Blue, State Tax Commissioner in Public Documents, West Virginia, 1915-1916, Volume Two (Charleston, WV: Tribune Printing, 1917), 5.

32 Lockard, “The Temperance Movement," 40.
} 
approach was the direct opposite of the patient, gradualist, and ultimately successful political strategy adopted by turn-of-the-century Mountain State drys. As William Link argues in his description of the move from local option to national prohibition in the South, "Each application of governmental power, reformers discovered, met a determined enough response to require the exercise of additional power." 33 Lawmakers faced a snowball effect where each new amendment eventually necessitated another adjustment. The more complex the law became, the more difficult it was to enforce. In turn, the more difficult it was to enforce, the bigger the law became.

There were scattered voices crying in the wilderness for patience. During the 1917 session, for example, Senator Hough of Brooke County voted against an adjustment, explaining that "I am unalterably opposed to the enactment of any more statutes upon the prohibition question until I see better enforcement of the present laws upon the subject." ${ }^{34}$ The vast majority of Mountain State legislators, however, lacked patience and dutifully adjusted state prohibition on a biennial basis as each perceived weakness, loophole, or defect emerged. This approach could be viewed as a bit ironic since many West Virginia drys and their allies had maintained that the law was supremely strict. A few months before the beginning of the Yost Law, the American Issue proudly reprinted an editorial from a newspaper in Huntington that described the measure as "absolutely air tight and uncompromising." 35 Prohibitionists had not necessarily misled the West Virginia public about the law they had written. They simply acknowledged that

\footnotetext{
${ }^{33}$ William A. Link, The Paradox of Southern Progressivism, 1880-1930 (Chapel Hill: University of North Carolina Press, 1992), 316.

${ }^{34}$ Journal of the Senate of the State of West Virginia for the $33^{\text {rd }}$ Regular Session, Commencing January 10, 1917 and the Extraordinary Session, Commencing February 24, 1917 and May, 1917 (Charleston, WV: Tribune Printing Company, 1917), 126.

${ }^{35}$ Huntington Herald-Dispatch, quoted in American Issue (West Virginia Edition), December 22, 1913, 8.
} 
their legislation, while "air tight and uncompromising" in a perfect world, was not as stringent as they had expected as COD advertisements dominated real-world newspapers on the eve of July 1 and liquor shipments flooded the Mountain State after the first.

When West Virginia drys proudly announced that the Yost Law was strict, they were comparing it to the other state prohibition laws of the time. Loopholes were a common feature in early twentieth century liquor proscription measures. According to Jack Blocker, "In many states, the people voted only for an anti-saloon law, one that would outlaw the liquor traffic while leaving private importation and possession of liquor untouched."36 The best explanation for this conditional form of prohibition lay in the name of its most vociferous supporter [the ASL]:

Prohibitionists did not take obvious step to stop the COD trade, the banning of personal consumption of liquor. The logic of that step was inescapable: if there was no legitimate reason to possess alcohol, there could be no legal reason to import liquors - the consignees would always be liable to state law.... The league made 'its war mainly' against the 'open saloon,' and the idea of personal use of liquor did not bolster the rights of the saloon. Besides, as a matter of tactics, the personal-use exemption aided the league. It pacified wets in dry areas; they could get their liquor and so had little reason to try to repeal prohibitory laws. Similarly, it made prohibition laws and local option laws easier to sell to the public. $^{37}$

Personal-use provisions in one form or another stayed on the books until after the ratification of national prohibition by the legislature in 1919. However, legislators and their dry allies targeted the COD trade within months of the Yost Law's July 1, 1914, launch. Governor Hatfield quoted a prominent mine operator in his 1915 address: "I firmly believe that prohibition has worked and

\footnotetext{
${ }^{36}$ Jack S. Blocker, Retreat from Reform: The Prohibition Movement in the Unites States, 1890-1913 (Westport, CT: Greenwood Press, 1976), 239.

${ }^{37}$ Richard F. Hamm, Shaping the Eighteenth Amendment: Temperance Reform, Legal Culture, and the Polity, 18801920 (Chapel Hill: University of North Carolina Press, 1995), 182.
} 
will continue to work to the interest and benefit of the entire state. And were it not for liquor shipped and brought into this State from outside there would be a still better condition shown." ${ }^{38}$

The first legislature to convene after the imposition of state liquor proscription would seek to limit COD shipments. After all, delivery of liquors from wet states into West Virginia had been a thorn in the side of drys since before the beginning of the Yost Law. As Lockard argues, "The first problem that presented itself was that of holding back liquors from surrounding states, which permitted the traffic." ${ }^{\prime 39}$ Developments in chapter four indicate that legislators and their teetotaler allies had been waging war on the COD business since the turn of the twentieth century. This time, however, lawmakers would be banning the shipment of liquors into all of West Virginia and not just individual dry counties. Mountain State solons had faced constitutional concerns during their initial attack on COD vendors in the first decade of the 1900s. ${ }^{40}$ Logically, then, one would assume that these legal debates would have only intensified with the 1915 legislature's broadened goal of banning COD deliveries into the entire state. After all, did the state of West Virginia have the right to interfere with interstate commerce, even if that particular form of commerce violated its organic law?

The passage of a key federal law in 1913 insured that the answer to this question was an unequivocal "yes." The year 1913 proved to be one of the most important years in the development of prohibition in the Mountain State. While West Virginia ASL and legislative leaders crafted and passed the Yost Law, lawmakers in Washington were busy making fundamental changes to the organic constitutional law of the United States. Prohibitionists

\footnotetext{
${ }^{38}$ First Biennial Message of Governor Hatfield, 44.

${ }^{39}$ Lockard, “The Temperance Movement," 41.

${ }^{40}$ For more information on the constitutional debate, see chapter four and chapter six of Hamm, Shaping the Eighteenth Amendment.
} 
maintained that, in order to halt COD liquor in states like West Virginia, they needed Congress to change the federal government's policy on interstate commerce. As Hamm explains, drys believed that "the 'success or failure' of prohibition depended 'upon the attitude of the general government.' The key to changing the federal government's position was the passage of an interstate commerce law. Drys crossed this 'last ditch' with the Webb-Kenyon Act of 1913."41 President Taft and other critics had constitutional qualms about the measure. According to its opponents, "By divesting intoxicating liquors of their interstate character as soon as they crossed a state line, Congress ... was delegating to the states the power to regulate interstate commerce." Ultimately, legislators passed Webb-Kenyon over the president's veto. It "prohibited the importation into a state of any intoxicating liquors that were intended to be received, kept, or used in violation of the laws of that state." 42

In spite of its dubious constitutionality, the Webb-Kenyon Law was a theoretical gamechanger for West Virginia drys. As Hamm argues, the measure "made effective state action against the interstate liquor industry. It revitalized old laws and stimulated prohibitionists to turn quickly to new tactics, including new state liquor transportation regulations." ${ }^{43}$ De facto West Virginia prohibition commissioner Fred Blue acknowledged the importance of Webb-Kenyon at a speech in Huntington on February 8, 1914. Blue reminded his audience that "the enactment of the Webb-Kenyon Law will be of considerable assistance in enforcement of the Prohibition law."44 Commissioner Blue decided to use this new federal protection to push for

\footnotetext{
${ }^{41}$ Hamm, Shaping the Eighteenth Amendment, 211-212.

42 James H. Timberlake, Prohibition and the Progressive Movement (Cambridge, MA: Harvard University Press, 1963), 162.

${ }^{43}$ Hamm, Shaping the Eighteenth Amendment, 220-221.

${ }^{44}$ American Issue (West Virginia Edition), February 16, 1914, 4.
} 
reinforcements of the Yost Law in a written response to the West Virginia ASL. He called for "three necessary amendments." First among these proposals was an adjustment to "make it unlawful for any common carrier, or its agents, to deliver intoxicating liquor ... to any person in the state for any purpose, personal or otherwise." In its approval of Blue's letter, the ASL reminded its supporters that "the Yost law was prepared before the passage of the Webb-Kenyon law. At that time it went as far as federal law would allow." ${ }^{45}$ Of course, West Virginia wets and their allies, who already believed that the original Yost Law was a bridge too far, reacted with alarm and astonishment to the news of Blue's legislative marching orders. The National Liquor Dealers' Association, for example, opined that "the proposal of Commissioner Blue is absolute confession that the Prohibition law in West Virginia has been a failure and that the only way to make it more effective is to make it more prohibitory. It is non-effective because it is too prohibitory already and not in accordance with the first principles of personal liberties." ${ }^{46}$

The West Virginia ASL had already rejected the wets' invocation of personal liberty earlier in 1914. According to the American Issue, "Personal liberty means liberty to do right. Freedom to do wrong is not liberty but license.... If [the liquor trade] is a curse then the duty of every good citizen is as clear as daylight. Demand its extinction." ${ }^{, 47}$ They received some help in their quest to slay the liquor dragon as the 1915 session convened. Drys realized that, in order to take maximum advantage of the Webb-Kenyon law, they needed to redefine how legal authorities interpreted the COD trade. The key to this effort was defining West Virginia as the point of sale instead of the wet states from where the shipments originated. They "argued that

\footnotetext{
${ }^{45}$ American Issue (West Virginia Edition), November 9, 1914, 3-4.

${ }^{46}$ Quoted in American Issue (West Virginia Edition), December 7, 1914, 3.

${ }^{47}$ American Issue (West Virginia Edition), February 16, 1914, 8.
} 
since the place of sale was dry territory, liquor shipments into such areas were intended to be used in violation of state laws prohibiting liquor sales." This attempted redefinition, of course, compelled liquor interests to file lawsuits based on the argument that "state point-of-sale laws" were unconstitutional. ${ }^{48}$ In early 1915, the United States Circuit Court of Appeals in Richmond found in favor of Mountain State drys. It decided "that the State of West Virginia can legally declare the place of sale of an article to be at the place of delivery." To the ASL, this meant "that every delivery of liquor within the state consigned by the liquor dealers to the citizens of West Virginia was a violation of the law." It also decreed that "in the police power of the State it finds authority for the prohibition of the importation of alcoholic drinks or any other articles of commerce that may be considered injurious." ${ }^{49}$ Editors at the Intelligencer saw the writing on the legislative wall. According to an editorial in late January, elements of the decision "arm prohibition legislation with weapons of great power. . . No railroad, transfer company, express company or individual may safely import liquor into West Virginia, if this theory of the law is sustained." $" 50$

Legislators moved quickly to use their reinforced weapons as the 1915 session convened. They passed three separate measures bolstering the Yost Law during the regular and second extra sessions. Codified restrictions on the COD trade dominated these new regulations. State senators passed Fred Blue's senate bill 79 by a vote of twenty-seven to three on January $27 .{ }^{51}$

\footnotetext{
${ }^{48}$ Hamm, Shaping the Eighteenth Amendment, 222.

${ }^{49}$ Wheeling Intelligencer, January 25, 1915; American Issue (West Virginia Edition), February 1, $1915,4$.

${ }^{50}$ Wheeling Intelligencer, January 25, 1915.

${ }^{51}$ Journal of the Senate of the State of West Virginia for the Thirty-Second Regular Session Commencing January 13, 1915 and the Extraordinary Session Commencing February 27, 1915 and May 18, 1915 (Charleston, WV: Tribune Printing, 1915), 161; Wheeling Intelligencer, January 27, 1915.
} 
Delegates acted with similar near unanimity two days later, authorizing the bill seventy-three to six. ${ }^{52}$ Senate bill 79 included eight sections amending the existing state prohibition law. Chief among these was an order banning liquor shipments by common carrier. According to the code, "no common carrier, for hire, nor other person for hire or without hire, shall bring or carry into this state, or carry from one place to another within this state, intoxicating liquors for another, even when intended for personal use; except a common carrier may, for hire, carry pure grain alcohol and wine."53 While it did allow the personal importation of liquor, the legislature tightened the prohibitory noose further with other measures. These included the removal of local officials for refusing to enforce prohibition, the relocation of liquor trials to other counties if officials deemed it necessary, and the granting of immunity for those witnesses testifying on behalf of the state. ${ }^{54}$

Three senators - Strother from McDowell County, Rosenbloom from Ohio County, and Gregory from Wood County - voted against the measure. ${ }^{55}$ Strother and Rosenbloom were especially vocal in their opposition on the Senate floor. During the bill's second reading on January 26, Senator Rosenbloom argued "that when the prohibition amendment was ratified it was the intent of the people to prohibit the manufacture, sale or keeping for sale of intoxicants in the State, and it was not to interfere with one's private use." He also attempted to remove the sections granting state officials the right to move trials to other counties and the half-gallon limitation on personal importation - the vast majority of his colleagues rejected these

\footnotetext{
${ }^{52}$ Wheeling Intelligencer, January 30, 1915.

${ }^{53}$ Acts of the Legislature of West Virginia, Regular and Extra Sessions, 1915 (Charleston, WV: Tribune Printing, 1915), 35.

${ }^{54}$ Acts of the Legislature, $1915,33-38$.

${ }^{55}$ Wheeling Intelligencer, January 28, 1915.
} 
adjustments. ${ }^{56}$ A day later, senators accused Strother of trying to filibuster the measure. According to the Intelligencer, "He referred to the old blue laws of Puritan days, when they burned witches at the stake ... quoted Scriptures, and wound up by asserting with emphasis that he was going to vote against the bill. ${ }^{, 57}$

The senator from McDowell County went on to make a statement that would prove to be, in hindsight, prescient as state and federal prohibition collapsed a few years later. Strother argued that "you may pass the bill, but people will satisfy their desire. I have my home, and it is my castle. If I can't get liquor one way, I may even dig a hole in my cellar and have a gallon-aday distillery. ${ }^{, 58}$ Most of the six delegates presented similar arguments in their rejection of senate bill 79 in the House of Delegates. Similar to his senatorial colleague, Ohio County's Delegate Weiss assailed the section authorizing the relocation of trials to other counties. Even Delegate Brown, a supporter of the bill, "believed this section to be unconstitutional." Weiss' attempted adjustment failed in the house. ${ }^{59}$ It is important to note that not all of the six dissenters rejected the bill because they were anti-prohibitionists. Kanawha County delegate Barlow rejected the bill because it was not dry enough. He disagreed with the personal-use exemption and explained "that he opposed any bill which would permit liquor to be brought into the State in any amount under any circumstance and for any purpose.." ${ }^{, 00}$ The Intelligencer divined the meaning of the overwhelmingly supportive votes in the legislature and even granted its tacit support for the amendments. According to the editors, "It will be seen from this vote that there

\footnotetext{
${ }^{56}$ Wheeling Intelligencer, January 27, 1915.

${ }^{57}$ Wheeling Intelligencer, January 28, 1915.

${ }^{58}$ Quoted in Wheeling Intelligencer, January 28, 1915.

${ }^{59}$ Wheeling Intelligencer, January 30, 1915.

${ }^{60}$ Wheeling Intelligencer, January 30, 1915
} 
has been no change in the minds of the people with regard to prohibition.... So long as prohibition is a part of the constitution, its inhibitive features should be strictly conserved, else it becomes a farce and encouragement to lawlessness." ${ }^{\text {61 }}$

The 1915 legislature overwhelmingly passed two more inhibitive features by the end of the second extra session in May. The first, passed during the regular session, required liquor shippers to keep written records of their cargo. Of course, this cargo could only include "pure grain alcohol and [sacramental] wine for the purposes prescribed by law." ${ }^{, 62}$ The second measure, authorized during the second extraordinary session, theoretically choked off the COD trade in West Virginia on both ends. While Blue's bill passed during the regular session banned liquor companies from shipping booze into the Mountain State, senate bill six made it illegal for West Virginians to receive the same shipments. According to the measure, "Any person violating this section shall be guilty of a misdemeanor and upon conviction shall be fined not less than one hundred dollars nor more than two hundred dollars, and in addition thereto may be imprisoned not more than three months. ${ }^{, 63}$ Dry and wet organs reacted to the 1915 amendments with predictable philosophical consistency. Pointing out that Webb-Kenyon banned liquor importation "in violation of any law of a state," the American Issue confidently opined that "under section 34 [the adjustment passed during the second extra session] of our law we need not fear the shipment of liquor into West Virginia." ${ }^{64}$ The Intelligencer, concerned over the strictness of the recent adjustments, argued "that the advocates of prohibition have weakened their cause instead of strengthened it by amending the already drastic Yost law." Focusing on

\footnotetext{
${ }^{61}$ Wheeling Intelligencer, January 30, 1915.

${ }^{62}$ Acts of the Legislature, 1915, 221-222.

${ }^{63}$ Acts of the legislature, $1915,660-661$.

${ }^{64}$ American Issue (West Virginia Edition), June 7, 1915, 8.
} 
the "rights and privileges of the citizen," the editors warned their readers that "this is nothing more than temperance run into intemperance, a factional element made drunk with power. It is destroying the very thing that prohibition stands in need of to become effective - a sustaining sentiment." 65

The alcohol interests and their wet allies used the Mountain State as a cautionary socioeconomic tale in their publications. To them, state prohibition as attempted in West Virginia had done significant damage to state coffers, not to mention the rights of the citizenry, with little discernable benefit. The National Liquor Dealers' Journal contained an article entitled "A West Virginia Lesson" in the spring of 1915. According to the publication, "A practical result of Prohibition is now being experienced in West Virginia. There is a big deficit in the treasury of that state because of the abolition of receipts accruing from the liquor licenses." Liquor dealers also doubted the moral and functional efficacy of state prohibition. They argued "that so far Prohibition has not in any sense whatever benefitted West Virginia morally. ... In a little dry town close to Wheeling there are no less than 150 illegal liquor dens. So that while the state is losing hundreds of thousands of dollars per year because of Prohibition, liquor drinking is going on just as brisk as usual."

The United States Brewers' Association launched by far the most aggressive attack on West Virginia state prohibition in its 1915 Year Book. The wet group included a ten-page investigation of the "Record of Prohibition in West Virginia." This piece assailed the Yost Law on almost every level and from almost every angle. The writer argued that the "F.O. Blue issued upon [the Yost Law's first anniversary] a statement in which he claimed that prohibition in one

\footnotetext{
${ }^{65}$ Wheeling Intelligencer, May 26, 1915.

${ }^{66}$ Quoted in American Issue (West Virginia Edition), March 29, 1915.
} 
year had reduced drunkenness 'practically seventy-five per cent' and decreased crime 'practically 50 per cent.' Further along in this article I will demonstrate to the reader the utter unreliability of Mr. Blue's figures." The author attempted to prove this unreliability by pointing out that the state did not regularly register crime statistics and that the two years compared 1913-1914 and 1914-1915 - were skewed because the coalfields hosted widespread strikes during 1913-1914 and not during 1914-1915, thus artificially enhancing crime rates during the first year. ${ }^{67}$ According to the writer, "West Virginia is another prohibition State the finances of which have become badly disarranged." The Yost Law removed $\$ 650,000$ of license revenue and necessitated the passage of a new tax bill. "The Omnibus Revenue Law increases the property tax from ten to fourteen mills on the dollar, the highest tax rate ever known in West Virginia. Previous to the passage of the prohibitory law, the property tax ... was only six mills on the dollar." 68 The USBA also assailed the power of the Mountain State's prohibition bureaucracy. According to the article, "In view of the fact that Commissioner Blue and his agents enjoy all of the powers vested in the attorney-general of the State, their authority is superior to local officials.... A careful examination of the powers with which it is clothed has convinced me that as long as the 'Blue Army' lives, liberty is menaced in West Virginia." Of course, as the USBA argued, a state bureaucracy as large and powerful as "Blue's Army" was also subject to widespread "oppression and graft." 69

\footnotetext{
${ }^{67}$ The 1915 Year Book of the United States Brewers' Association, Containing the Reports Delivered at the $55^{\text {th }}$ Annual Convention Held in Springfield, Mass., October 13-16, 1915, and Added Chapters (New York: United States Brewers' Association Publishing, 1915), 165 and 172.

${ }^{68}$ The 1915 Year Book of the USBA, 26-27.

${ }^{69}$ The 1915 Year Book of the USBA, 170-171.
} 
At the end of the article, the author pointed out "Some Observations in Conclusion." These observations included a summary of the failures of state prohibition in every corner of West Virginia. In the state's capitol city, for example, "forty per cent of the time of the justice courts ... is taken up by trying cases of violation of the liquor laws. Liquor comes in by railroad, by automobile, by river and by every conceivable means. And Charleston is the 'dryest' town in the State!"70 These almost farcical law enforcement conditions extended to the Mountain State's border towns. Citizens in Ohio River locales and in the Eastern Panhandle could simply cross the border, frequent an illegal saloon, or wait for shipments from Maryland. Of course, "the average mountaineer of West Virginia can make 'fair' liquor while you wait. . . You can get it 'warm from the still,' and whole barrels of it are secreted in rafts and floated down the Kanawha to Charleston and way stations."71 Finally, the heavy financial toll exacted by state prohibition in West Virginia's cities created a negative attitude towards liquor proscription among many citizens. As the article stated, "Popular resentment is not in the least veiled. Good men will tell you that their state is bankrupt and that prosperity in the cities has been struck a heavy blow by prohibition."72

The aggressive attacks on the Yost Law by liquor interests during its infancy required equally assertive and defensive responses from state officials and their dry allies in 1915 and 1916. These retorts usually focused on the sometimes speculative socioeconomic benefits of liquor proscription. During his 1915 message to the legislature, Governor Hatfield conjectured that the decrease in crime, industrial accidents, and mental illness referrals resulting from state

\footnotetext{
${ }^{70}$ The 1915 Year Book of the USBA, 174.

${ }^{71}$ The 1915 Year Book of the USBA, 174.

${ }^{72}$ The 1915 Year Book of the USBA, 174.
} 
prohibition "will work to the relief of our tax-payers and will guarantee a higher standard of citizenship from every point of view."73 Fred Blue attempted to defend his teetotaler regime against the wet contention that prohibition led to a fiscal crisis in a speech in Clarksburg. Blue contended that, because the state had run a deficit before the end of the liquor license system, it was not entirely the fault of state prohibition that West Virginia suffered from a larger budget shortfall in $1915 .^{74}$ He also advanced the familiar dry argument that liquor proscription limited crime in his first official report as de facto Commissioner of Prohibition. According to Blue, "The state has been greatly benefited by prohibition. True, in some counties there have been large numbers of indictments for violations of the prohibitory laws. But, on the whole, crime has largely decreased." The commissioner backed this contention with comparative crime statistics from several Mountain State cities. ${ }^{75}$ While arrests for drunkenness did decrease between the last year of free liquor and the first year of state prohibition, one wonders if the underground nature of illegal alcohol made fewer West Virginians subject to arrest.

Mountain State evangelicals also registered their support for the law they had helped to pass a few years earlier. West Virginia Baptists issued several resolutions at their Logan convention in 1916. Key among these were proclamations extolling the socioeconomic virtues of state prohibition, arguing that "there is a strong demand throughout the state for the law to be amended so as to make it more drastic," and reminding its members that eternal vigilance was the price of dry victory. ${ }^{76}$ Drys frequently reprinted supportive statements from government, industry, and labor leaders. Editors at the American Issue, for example, posed the question "does

\footnotetext{
${ }^{73}$ First Biennial Message of Hatfield, 45.

${ }^{74}$ American Issue (West Virginia Edition), March 29, 1915, 3.

${ }^{75}$ First Biennial Report of the State Tax Commissioner, 8-9.

${ }^{76}$ Quoted in American Issue (West Virginia Edition), October 23, 1916, 4.
} 
prohibition pay?" on the front page of their August 14 edition. Their answer was, of course, "yes." The article highlighted supportive statements made by the West Virginia Commissioner of Labor, Chief of the Department of Mines, President of the United Mine Workers of America (UMWA) District 17 chapter, and an excerpted article from the Coal Trade Journal. These quotations focused on the prohibition system's positive impacts on work efficiency and miner welfare. ${ }^{77}$ Fred Blue cited letters from state leaders in his annual report. According to the tax commissioner, his contention that the Yost Law had suppressed crime in West Virginia "is further sustained by the letter of M.Z. White, warden of the state penitentiary." White cited a drop in total prison population since the enactment of liquor proscription and argued that "the largest majority of [the inmates] were under the influence of liquor at the time they committed the crimes for which they are convicted." The superintendent of the Huntington State Hospital opined that cases of "alcoholic insanity" had dropped 75 percent since the imposition of the Yost Law. Finally, Blue shared excerpts from the same UMWA letter his allies at the Mountain State ASL had reprinted in August. ${ }^{78}$

The United States Supreme Court rendered a decision on January 8, 1917, that bolstered the legitimacy of the prohibitionists' anti-importation measures passed during the 1915 legislative session. In the Clark Distilling Company v. Western Maryland Railroad Company and Clark v. American Express Company cases, shipping firms had refused "to carry liquor into West Virginia because its point-of-sale law made such shipments liable for seizure. The central issue in the Clark case was the constitutionality of the Webb-Kenyon Act; the legitimacy of the West Virginia law was secondary." In a split decision, the Supreme Court ruled that the

\footnotetext{
${ }^{77}$ American Issue (West Virginia Edition), August 14, 1916, 3.

${ }^{78}$ First Biennial Report of the State Tax Commissioner, 9-10.
} 
Mountain State retained the right to ban personal-use shipments and that Webb-Kenyon was constitutional. This meant that "common carriers could refuse [liquor] shipments, and courts could not force them to accept such shipments." Wets asserted that the decision would cool off agitation for national prohibition now that states could legally protect themselves and "that it would slow down state prohibition because now many states would be trying to go bone dry and people would refuse such an extreme policy." Dry forces, however, "saw the Clark decision as a key step to total prohibition." One ASL leader opined that "the ruling "cleared the decks for action for the final overthrow of the beverage liquor traffic." ${ }^{, 79}$ New de facto Commissioner of Prohibition Walter Hallanan reiterated the dry position in his 1917-1918 report. Hallanan credited former commissioner Fred Blue for successfully managing the state's position in the Clark case. According to Hallanan, "This is truly an epoch-making decision in the history of prohibition." The new commissioner hailed the decision as a clarification and reinforcement of the rights of the individual states over the liquor trade. Hallanan announced that "the States have plenary power to deal with the subject of liquors as they choose."

Legislators used these powers to enhance the Yost Law during the 1917 session in Charleston. State politicians had attempted to choke off the COD liquor trade with their adjustments in 1915. With the Clark decision in early 1917, dry West Virginians now had the legally protected right to enforce their anti-importation laws. In the eyes of many teetotaler activists and administrators, however, it was time to up the ante and stop the prevalent flow of bootleggers crossing into the Mountain State as a result of the Yost Law's liberal personal-use

\footnotetext{
${ }^{79}$ Hamm, Shaping the Eighteenth Amendment, 224-225.

${ }^{80}$ Second Biennial Report of the State Tax Commissioner of West Virginia, Ex-Officio State Commissioner of Prohibition for the Fiscal Years 1917-1918, Walter S. Hallanan, State Tax Commissioner in Public Documents, West Virginia, 1917-1918, Volume Two (Charleston, WV: Tribune Printing, 1918), 4-5.
} 
loophole. Citing Commissioner Blue's recommendations, Governor Hatfield opined that "in order to correct [bootlegging] this condition it seems to me that the legislature should define the amount that may be brought into the state... so that the loophole in the law which has been taken advantage of by unscrupulous persons who engage in the sale of intoxicating liquors may be eliminated." ${ }^{\prime 11}$ The West Virginia ASL reassured its members that "the League takes the stand that it is not necessary to legalize shipments of liquor into the state." However, according to the American Issue, "if liquor is allowed to enter the state at all it should be where one personally carries it into the state and that the amount should be made so exceedingly small that no one can afford to leave the state for all the liquor he would be allowed to carry home with him." 82

The Mountain State ASL's seemingly resigned position on the 1917 session's impending prohibition legislation proved to be as noteworthy as it was prescient. Lawmakers were willing to strengthen the Yost Law; they were just unwilling to stem completely the tide of personal-use liquor. After all, it was one thing to limit personal importation of liquor into the state to stop bootlegging. It was quite another thing to cut off completely the one remaining avenue by which thirsty West Virginians could quench their thirst for liquor. Paradoxically, wet journalists and politicians seized on this seemingly duplicitous teetotaler position and criticized anti-liquor representatives for avoiding a bone-dry prohibition law. On the upper house floor, Senator Rosenbloom of Ohio County, a noted anti-prohibitionist, attempted to strike out the one-quart importation loophole contained in Senate Bill 116. He argued "that that would give West Virginia practical prohibition. 'Under present conditions it has been a flat failure."’83

\footnotetext{
${ }^{81}$ Second Biennial Message of Governor Henry Hatfield to the 1917 Legislature (n.p., n.d.), 61.

${ }^{82}$ American Issue, (West Virginia Edition), January 20, 1917, 1.

${ }^{83}$ Quoted in Wheeling Register, January 17, 1917; delegates and senators are identified by county of residence in JC Dillon, ed., West Virginia Blue Book, 1976 (Charleston, WV: Jarrett Printing, 1976), 280-285 and 290-310.
} 
Rosenbloom had hardly seen the light on state prohibition. Rather, as Jack Blocker has described in his work, the senator realized that completely cutting off liquor importation would cause the Yost Law to lose what support it enjoyed and remove the last consumption safety valve for thirsty residents. According to another senator, "such an amendment was intended to make the bill unpopular." 84

Supporters of the measure expressed concerns both about the wisdom of acceding to yet another adjustment to the organic prohibition law and its relative strength. Senator Hough, a dry politician from Brooke County who ended up voting against the bill, opposed the one-quart every thirty days loophole and refused to support "any more statutes upon the prohibition question until I see better enforcement of the present laws. ${ }^{" 85}$ Senator Carter proclaimed "that West Virginia voted for prohibition in 1912 and now it is the duty of the legislature to abolish the importation of liquor." Senator Lowe argued that Senate Bill 116 would begin a process of gradually lowering the personal importation exemption amount until it disappeared.

Rosenbloom attempted to amend the bill a couple more times, but the vast majority of the body rejected his adjustments. Ultimately, the untouched bill passed twenty-four to three on January 26 as most dry politicians swallowed their teetotaler pride. ${ }^{86}$ The Wheeling Register quickly assailed the state senate for passing such a duplicitous bill. According to the editors, "If the prohibitionists and members of the legislature really want to make the state 'bone dry,' the 'one quart per month' clause should be striken out." The wet organ went on to point out "what good would the old Masoic laws have been had Moses written (if he did write) on the tables of stone:

\footnotetext{
${ }^{84}$ Wheeling Register, January 27, 1917.

${ }^{85}$ Journal of the Senate of the State of West Virginia, 1917, 126.

${ }^{86}$ Wheeling Register, January 27, 1917.
} 
'Thou shalt not steal' - except once a month. 'Thou shalt not kill' - except once a month. 'Thou shalt not bear false witness against thy neighbor' - except once a month?"87

In spite of concerns from both sides of the aisle, the bill breezed through the House of Delegates a few days later. As in the upper house, there were attempts by several representatives to amend the measure. Delegate Weiss of Ohio County, for example, tried to increase the importation limit from one to four quarts. Dry Delegate Bray of Greenbrier County advanced amendments banning the importation and transportation "of any quantity of intoxicants whatsoever." The vast majority of teetotaler delegates, whether they liked the importation clause or not, closed ranks around the bill because they feared "that to begin to amend would possibly cripple the measure in such a manner that it would not pass the Senate when, amended as proposed, it would necessarily be introduced there again." ${ }^{88}$ The measure passed on January 31 by a vote of eighty-six to five, with only Ohio County Delegates Emsley, Otto, Whitaker, and Weiss and Hampshire County's Delegate Carder rejecting Senate Bill 116. The West Virginia ASL, which along with other dry groups and the de facto prohibition commissioner had written the law, could not hide its pride in the American Issue. ${ }^{89}$ As the federation claimed, "That sentiment for prohibition is stronger in West Virginia than ever is evidenced by the action of the Legislature in passing the McAboy - Harvey bill." ${ }^{, 90}$ Even the Intelligencer admitted that support for the measure appeared to be overwhelming in its editorial entitled "Nearly Unanimous." According to the editors, "The passage of the quart limitation bill ... shows very clearly that the people of West Virginia have again ratified through their representatives in the 
legislature their faith in prohibition." The Wheeling daily even dismissed the importance of its local representatives' votes, arguing that "the fact that the Ohio county delegation voted solidly against the measure conveys no other significance than that the gentlemen were reflecting the sentiments of the large majority of their constituents." ${ }^{.11}$

Indeed, as it had in 1912, Wheeling appeared to be one of the few localities in the Mountain State standing against the state prohibition system. The ASL and Intelligencer were probably not overstating the overwhelming support for the Yost Law in legal and political circles. Legislators and pro-law and order journalists - with the possible exception of the Wheeling Register - were willing to give state liquor proscription a chance. However, what they failed to recognize at the time was that, in accepting an increasingly uncompromising, airtight, and ultimately unpopular form of prohibition, they were undermining their own cause. In its 1916 yearbook, the United States Brewers Association (USBA) listed relatively liberal importation regulations in the various states and argued that "these statements would seem to show that sentiment in favor of total abstinence has not yet reached any such proportion as would indicate that a prohibition era is at hand." ${ }^{.2}$ The 1917 adjustments to the Yost Law also included clauses that could have been interpreted by average citizens as attacks on personal liberties and property rights - the very same talking points advanced by wet groups. The Mountain State ASL, of course, considered the 1917 legislative package "an extremely strong act." These enhancements included the possible forfeiture of a tenant's residential lease if the tenant "used the premises in violation of the Prohibition law," the loss of a citizen's business license if that

\footnotetext{
${ }^{91}$ Wheeling Intelligencer, February 1, 1917.

92 The 1916 Year Book of the United States Brewers' Association, Containing The Principle Reports Delivered at the $56^{\text {th }}$ Annual Convention Held in Cleveland, Ohio, November 21-24, 1916, and Added Chapters (New York: United States Brewers' Association Publishing, 1916), 170.
} 
citizen's establishment housed any prohibition violations, and even the loss of one's vehicle license if their car carried more than one quart of booze. In addition, the law deemed a second offense of carrying more than one quart of liquor into the state a felony with a prison sentence of from one to five years. ${ }^{93}$

While ASL leaders supported a tighter and tighter Yost Law, they realized that "its effectiveness will depend not only upon the activity of the officers of the law, but upon the stand taken by the friends of the law." ${ }^{94}$ The group they left out in this statement was the average, undecided Mountain State resident - the West Virginian who may have supported the idea of state prohibition in 1912 but started to doubt his decision by the late 1910s. Of course, other West Virginians simply flaunted the law and never stopped drinking. According to historian Deborah Weiner, "Although the more reputable saloon moved into other lines of business, much of the [southern coalfields] populace did its best to ignore prohibition. Jews, like others, continued to be consumers." ${ }^{95}$ Some bureaucrats and law enforcement officials also willfully violated the Yost Law. For example, as Weiner cites, "One man who grew up in Welch recalled that wine for his bar mitzvah was supplied by the county sheriff." $" 96$

Drys and their legislative allies attempted to alleviate this particular problem by writing into the prohibition law mechanisms for the removal of public officials who failed to enforce state prohibition. Originally inserted during the 1915 session, legislators enhanced the clause in 1917. According to the section, "If any mayor of a municipality, or the person acting as such, the municipal police, county, or district officer, shall fail, refuse or neglect to discharge any duty

\footnotetext{
${ }^{93}$ American Issue (West Virginia Edition), May 5, 1917, 3.

${ }^{94}$ American Issue (West Virginia Edition), May 5, 1917, 3.

${ }^{95}$ Deborah R. Weiner, Coalfield Jews: An Appalachian History (Urbana: University of Illinois Press, 2006$), 102$.

${ }^{96}$ Weiner, Coalfield Jews, 102.
} 
imposed upon him by law, prohibiting the manufacture, sale, keeping and storing for sale intoxicating liquors, he shall be removed from office." ${ }^{97}$ Editors at the Intelligencer grudgingly supported this particular clause, arguing that "as long as we have the prohibition law it ought to be enforced because it is the law, and not evaded because it is not endorsed by what is called public sentiment in any particular community. . . . Condoning the abrogation of one law is a step toward lessening the respect for all law."98

Of course, Mountain State residents would soon be obliged to respect and enforce an even more complete form of liquor proscription. The West Virginia ASL had shifted its focus to a national prohibitory system by $1917 .{ }^{99}$ The ASL tied much of its campaign for national prohibition to a particularly nasty combination of caterwauling wartime "patriotism" and antiGerman American bigotry. Congress passed a constitutional prohibition amendment on to the states - usually their legislatures - in December of $1917{ }^{100}$ The West Virginia delegation left little doubt that they hailed from an already arid state. All five of the Mountain State's congressmen voted for the amendment's submission. ${ }^{101}$ Before and as drys waited for the individual states to decide on the national amendment, they pushed for various wartime prohibition measures. These laws were ostensibly marketed "in the interest of efficiency in the army and navy and for the sake of conserving the food supply by stopping the waste of grain which goes into the manufacture of intoxicating liquors." Of course, the agitation for a war-

\footnotetext{
${ }^{97}$ Acts of the Legislature of the State of West Virginia, Regular Session, 1917 (Charleston, WV: Tribune Printing, 1917), 182.

${ }^{98}$ Wheeling Intelligencer, February 1, 1917.

${ }^{99}$ While this shift is impossible to quantify, it becomes clear that they were expanding their efforts to the national campaign by American Issue (West Virginia Edition), September 22, 1917.

${ }^{100}$ Timberlake, Prohibition and the Progressive Movement, 175.

${ }^{101}$ American Issue (West Virginia Edition), December 29, 1917, 2.
} 
related liquor proscription regimen was also "an appeal to patriotism." 102 Washington passed laws in the spring and summer of 1917 that forbade alcohol in and around military installations, banned the sale of alcohol to servicemen, and prevented foodstuffs from being used in the brewing of liquor products. ${ }^{103}$

This pro-American assault continued over the next few years as national politicians pushed the country closer and closer to nationwide prohibition. As Hamm argues, "The frenzied emotions of war mobilization carried over into the drive for national constitutional prohibition. The prohibitionists draped their political tactics in patriotic bunting. The war made it easy for drys to portray the predominantly German American brewers as subversives, if not traitors."104 The West Virginia ASL used this anti-German sentiment to push its agenda in the American Issue. Connecting German-American groups, brewers, and the Kaiser himself, the ASL claimed that "the American army received more injury in this transaction [a saloon owner in Ashland, Kentucky, selling booze to mobilizing troops] than it will receive from many thousands of German bullets. .. . How soon will this nation declare its independence of the Germanized saloon, the kaiser's ally in the United States?" beer and wine to the manufacturing ban and disallowed "the sale of all intoxicating beverages" in the fall of 1918. Because these new measures went into effect by the summer of 1919, "the nation actually went dry under War Prohibition on July 1, 1919, rather than on January 16, 1920, when the Eighteenth Amendment took effect."106

\footnotetext{
${ }^{102}$ American Issue (West Virginia Edition), April 21, 1917, 4.

${ }^{103}$ Timberlake, Prohibition and the Progressive Movement, 174.

${ }^{104}$ Hamm, Shaping the Eighteenth Amendment, 240.

${ }^{105}$ American Issue (West Virginia Edition), January 26, March 16, May 25, 1918, 1, 3, 3.

${ }^{106}$ Timberlake, Prohibition and the Progressive Movement, 180.
} 
Like many other state legislatures meeting in January of 1919, Charleston wasted little time in passing the national prohibition amendment. ${ }^{107}$ Governor John Cornwell left little doubt in the minds of the legislators that he supported the measure. According to Cornwell, "For our own protection, if for nothing else, I imagine the Legislature will cheerfully and speedily align West Virginia with the States that have already ratified the Amendment."108 On the very same day as Cornwell's address (January 8), the state senate unanimously adopted Senate Joint Resolution One. ${ }^{109}$ The House of Delegates decided on the measure on January 9. They passed the resolution for national constitutional prohibition seventy-eight to three. Ohio County delegates were the only ones to vote in the negative. ${ }^{110}$ It was not at all uncommon for states to ratify national constitutional prohibition quite quickly. This condition also occurred in Congress during the consideration of the actual amendment in 1916 and 1917. Hamm argues that "drys discovered that the war power was a handy tool to use against their enemies. The emergency surrounding war mobilization precluded long debate on the prohibition amendment." ${ }^{111}$ The Senate Resolution engendered little debate in Charleston. According to the Intelligencer, "Only one speech was made in opposition to the passage of the resolution, that by Delegate Richards who made his protest particularly against the haste with which the resolution was taken up."112

\footnotetext{
${ }^{107}$ American Issue (West Virginia Edition), January 25, 1919, 4.

${ }^{108}$ Biennial Message of Governor John J. Cornwell to the Legislature of 1919, January 8, 1919 (Charleston, WV: Tribune Printing, n.d.), 32.

${ }^{109}$ Wheeling Intelligencer, January 9, 1919.

${ }^{110}$ Wheeling Intelligencer, January 10, 1919.

${ }^{111}$ Hamm, Shaping the Eighteenth Amendment, 240.

${ }^{112}$ Wheeling Intelligencer, January 10, 1919.
} 
By the winter of 1920, it frankly did not matter how quickly the states had ratified the national prohibition amendment - it was a reality. West Virginia lawmakers had contracted war fever and had acceded to a theoretically airtight form of liquor proscription ostensibly for the Mountain State's own protection. The state prohibition enabling act that they had passed in 1913 was a shell of what the Yost Law and its federal constitutional counterpart had become by the beginning of the twenties. By 1921, Charleston would remove the few loopholes remaining in the state measure and impose upon West Virginia a complete system of prohibition. Many Americans, West Virginians included, may have been conditional prohibitionists when they accepted state prohibition, but national prohibition removed the possibility of importation safety valves or legal moderation. ${ }^{113}$ Under this new system, a citizen was either a teetotaler or a criminal - there simply remained no gray area in the eyes of the law. As one West Virginia judge uttered in 1923, “There is no such thing as personal liberty. Liberty consists in doing such things as may suit our own convenience so long as it does not interfere with the rights of another or with the public."114

The 1919 legislative session passed further enhancements to the Yost Law in their continuing rear-guard action against illicit liquor. These enhancements were largely based on the recommendations of de facto prohibition Commissioner Walter Hallanan. The commissioner called for "the seizure and confiscation of automobiles and other vehicles of conveyance used in the unlawful transportation of intoxicating liquors." Another recommendation, based on the perception that "our present statute is woefully deficient in prescribing a reasonable penalty for those engaged in the manufacture of [moonshine] liquor," requested that lawmakers classify

\footnotetext{
${ }^{113}$ Blocker, Retreat from Reform, 239.

${ }^{114}$ Annual Report from State Commissioner, 1922-1923, 9.
} 
illicit distilling as a felony. ${ }^{115}$ The legislature obliged and passed Senate Bill 129. This measure gave the state extensive power over the personal property of Yost Law violators. Vehicles used to carry illegal alcohol were now "subject to seizure, forfeiture, and confiscation by the state." In addition, "any person owning, operating, or having any interest in any moonshine still, shall be guilty of a felony" and liable for fines and jail time. ${ }^{116}$ Hallanan did not, however, necessarily push for the elimination of the one-quart loophole in his 1918 report. He believed that impending federal war prohibition would take care of the liquor traffic. ${ }^{117}$ The next regular legislative session closed this last importation loophole. By 1921, it was illegal "for any person to bring or carry into the state or carry from one place to another within the state ... any quantity of intoxicating liquors." 118

While there appeared to be significant cooperation between prohibition officials and politicians, a significant schism existed between Governor Cornwell and Commissioner Hallanan. In his address to the 1919 extra legislative session, Cornwell pointed to possible abuses and corruption within the Prohibition Department and admitted that "I had been forced to the conviction that our method of enforcing the Prohibition Law is wrong and inefficient." This frontal attack on Hallanan and his agents was partially designed to guard against abuses against innocent citizens and to "maintain the confidence of the people." Governor Cornwell also wanted to establish a state police force and argued that "if the $\$ 40,000$ used to employ special

\footnotetext{
${ }^{115}$ Second Biennial Report of Hallanan, 10, 16-17.

${ }^{116}$ Acts of the Legislature of West Virginia, Regular Session, 1919 (Charleston, WV: Tribune Printing, 1919), 384 and 389.

${ }^{117}$ Second Biennial Report of Hallanan, 16.

${ }^{118}$ Acts of the Legislature of West Virginia, Regular and Extraordinary Sessions, 1921 (Charleston, WV: Tribune Printing, 1920-21), 415.
} 
agents of the Prohibition Department is applied to the maintenance of high-class, uniformed, State Police, officers of the law, it will go a long way toward supporting such a Department, which will exterminate illicit stills, stop bootlegging and prevent many other crimes."119

Commissioner Hallanan and the Wheeling Register assailed Cornwell for the content of his legislative address. Hallanan demanded proof of the governor's charges and suggested that Cornwell attacked him because he opposed the state police bill. The commissioner also claimed that Cornwell "now has a 'tin badge' detective employed in an attempt to gather evidence which might in some way reflect upon the administration of the prohibition department."120 Editors at the Register pleaded for an end to the Cornwell - Hallanan spat and asked for proof, and, if necessary, an investigation of the Prohibition Department. They argued that "the Governor and the entire state know that the prohibition laws are not being enforced, but can it be proved when so many are opposed to their enforcement?"121 Governor Cornwell did not appreciate the Register's position. In a March 22 letter to W.L. Brice of the Democratic daily, Cornwell stated that "I am sorry that the Charleston Gazette and Wheeling Register, the two, big Democratic papers of the state, are absolutely giving me no support in my fight with the corrupt and criminal elements of the Republican Party. Of course, I know the motive controlling the Gazette."122

Evidence does suggest that Governor Cornwell's concerns were grounded in more than just political positioning. As early as 1917, Cornwell contacted Commissioner Hallanan with his

\footnotetext{
${ }^{119}$ Special Message of Governor John J. Cornwell to the First Extraordinary Session, March 11, 1919 (Charleston, WV: Tribune Printing, n.d.), 7-9.

${ }^{120}$ Quoted in Wheeling Register, March 20, 1919.

${ }^{121}$ Wheeling Register, March 21, 1919.

122 Cornwell to Brice, March 22, 1919, John Jacob Cornwell Papers, Box 99, West Virginia and Regional History Collection, West Virginia University, Morgantown, WV.
} 
concerns about possible corruption within the prohibition department. In a letter to Hallanan that he copied to the West Virginia ASL, the governor singled out a former slot machine owner and current McDowell County agent named Ben Gay. According to Cornwell, "support and maintenance [of the prohibition department] will be contingent upon the dismissal of Mr. Gay and the appointment of some one [sic] of your choice ... who will properly enforce the law and is in sympathy with it."123 During his spat with Commisssioner Hallanan two years later, the Governor engaged the Pinkerton's National Detective Agency with a personal check "to investigate the work of some state prohibition agents who, I believe have been interested in the illegal sale of whiskey." ${ }^{124}$ The Pinkerton's operative, E.P.R., billed Cornwell for a six and a half day investigation in western and southern West Virginia. While the agent found circumstantial evidence of fraud on the part of prohibition agents, the governor decided "in view of the thin air and complicated situation here, I felt further investigation, at this time, would be useless. I think [E.P.R.'s] work was all that any one [sic] could have done under the circumstances." 125

Cornwell's political friends and local judicial officials also corresponded with the governor at the time of the Hallanan fight. They confirmed many of the chief executive's suspicions. In one case, Governor Cornwell wrote C.W. Ferguson, Wayne County Prosecuting Attorney, and asked for his help in stopping bootleggers from crossing the Big Sandy Bridge under the protection of local prohibition agents. ${ }^{126}$ Ferguson responded several days later with a

\footnotetext{
${ }^{123}$ Cornwell to Hallanan, April 2, 1917, Cornwell Papers, box 99.

${ }^{124}$ Cornwell to C.C. Clark of Pinkerton's Cincinnati office, March 6, 1919; Memos, investigative and expense reports are located in the Prohibition Department Investigation, 1919-1920 folder in the Cornwell Papers, box 99.

${ }^{125}$ Cornwell to Clark, March 18, 1919, Cornwell Papers, box 99.

${ }^{126}$ Cornwell to Ferguson, May 24, 1919, Cornwell Papers, box 99.
} 
supportive letter. In it, the prosecutor stated that "I have been aware all along that there was something 'rotten in Denmark' with the Prohibition Department, and I did not need your controversy with Mr. Hallanan to inform me that all was not well in Prohibition circles.” Ferguson then made a claim that suggested a shockingly fraudulent level of coordination between local prohibition officials and political interests. The attorney claimed that "I was told in Huntington a few days ago that the new chief deputy prohibition officer . . . had ordered all of the prohibition men out of Kenova and Huntington and sent them back in the hills in chase of imaginary moonshiners in order to give the Harshbarger political henchmen a chance to load up and stock up with wet goods ... for the big election." 127

The state formed the Department of Public Safety (DPS) on June 29, 1919. In his 1921 legislative address, Cornwell wasted no time in justifying the existence of his new police force. According to the governor, because some local law enforcement and political officials were not always willing to cooperate in the amelioration of vice violations like bootlegging and illicit distilling, the DPS was "just as necessary as the police department of a city."128 According to Cornwell’s successor, Ephraim Morgan, “In 1921 the Legislature, responsive to public sentiment, placed the enforcement of the prohibition laws in the hands of the State prohibition commissioner, removing that office from the department of the State tax Commissioner." Morgan appointed W.G. Brown to the position of Prohibition Commissioner, confident that the new bureaucrat was "in complete accord and sympathy with the law and who has made an honest

\footnotetext{
${ }^{127}$ Ferguson to Cornwell, May 26, 1919, Cornwell Papers, box 99.

${ }^{128}$ Biennial Message of Governor John J. Cornwell to the West Virginia Legislature, January 12, 1921 (Charleston, WV: Tribune Printing, n.d.), 33-34.
} 
and impartial effort to enforce it." ${ }^{29}$ The official Prohibition head wasted little time cleaning house. Less than two weeks after being appointed on the first of October, 1921, Commissioner Brown sent a letter to every employee in the Prohibition Department stating that "I am accordingly treating all appointments made by Commissioner Hallanan as terminating on October $1^{\text {st }} \ldots$ I shall expect you to 'carry on' during this month. If you so desire, you may send me your application for appointment with your references."130

By the 1920s, Mountain State prohibitionists and the officials they depended on enjoyed bone-dry laws, strong penalties for violations, and a state office completely committed to dry enforcement and purged of its most corrupt elements. The mountains had, theoretically, been dried. However, in some ways, West Virginia had become wetter than it had ever been before. As historian Bruce Stewart argues, "Prohibitionists might have gained support for their cause, but they were never able to eliminate either the demand for or supply of alcohol." ${ }^{131}$ Regardless of the law, Americans get what they want. This attitude was no different in the case of liquor. As legislators continued to tighten the noose around alcohol, West Virginians simply found alternative ways to quench their thirst. What resulted was a feedback loop of enhanced enforcement and increasingly aggressive violation. They started by exploiting the Yost Law's COD loophole. They moved on to manipulating the personal-use exemption. They then made it and bought it themselves. At every point, Mountain State officials reacted and passed

\footnotetext{
${ }^{129}$ First Biennial Message of Governor Ephraim Morgan to the Legislature of West Virginia, 1923 (Charleston, WV: Tribune Printing, n.d.), 20-21.

${ }^{130}$ Fourth Biennial Report of the State Commissioner Prohibition of West Virginia for the Fiscal Years 1921-1922, W.G. Brown, State Commissioner of Prohibition in Public Documents, West Virginia, 1921-1922, Volume Two (Charleston, WV: Tribune Printing, n.d.), 5-6.

${ }^{131}$ Bruce Stewart, Moonshiners and Prohibitionists: The Battle over Alcohol in Southern Appalachia (Lexington: The University Press of Kentucky, 2011), 217.
} 
progressively more constrictive adjustments to the existing liquor proscription infrastructure. Yet, West Virginia remained awash in illegal hooch.

The main culprit in the Mountain State - and most of the Appalachians - was moonshine liquor. It is important to note that moonshining was not a new American industry. However, it certainly picked up in intensity during the 1920s. As Prohibition Commissioner Brown pointed out in his 1921-1922 biennial report, "conditions have so changed that the main problem of the state at present is the suppression of the manufacture and distribution of 'moonshine' liquor within the state. With the advent of national prohibition on January $16,1920 \ldots$ there should have been, under ordinary conditions, a corresponding falling off in violations." Even though bootlegging across state lines had been theoretically stopped by national prohibition, liquor crimes did not abate. Brown opined that "extraordinary conditions complicated the situation." According to the Commissioner, World War I had slowed down local courts and dry forces rested on their laurels after national prohibition. Also, the Yost Law did not adequately address the rise of the moonshiner at first - "the savage successor of the brewer, who had begun to make his appearance in rural districts and out of the way places as soon as the saloon was closed." Additionally, the State Tax Department was not the correct bureaucracy in which to place prohibition enforcement as the tax commissioner was preoccupied with his original task and the state did not appropriate enough funding for proper enforcement. Perhaps most insightfully, Brown identified "a decided let-down in the moral tone of the whole people as a result of the war. Men seemed to have become a little 'weary in well-doing,' and this spirit was reflected in a corresponding laxity in law enforcement."132

\footnotetext{
${ }^{132}$ Fourth Biennial Report of Commissioner Brown, 10-11.
} 
Moonshine production had been steadily growing in the United States even before the beginning of national prohibition. According to one USBA study, the number of stills seized had increased from 1,911 in 1910 to 4,087 in $1918 .{ }^{133}$ After 1920, however, the illicit liquor trade exploded. As Stewart points out, "The advent of [North Carolina] statewide prohibition in 1908 and national prohibition in 1919 only intensified North Carolinians' appetite for liquor and increased the profitability of moonshining. The struggling economy added to the problem." This was also the case in the Mountain State. Of the 3,549 total arrests made by the DPS in its first year of service, nearly a third $(1,177)$ were liquor related. The State Police made 387 moonshine arrests alone. ${ }^{135}$ The Department of Prohibition also had its hands full with illicit distillers. In the fifteen months between July 1920 and September 1921, prohibition agents made 1,459 arrests and captured 882 stills on their own without local assistance. In the following nine months between October 1921 and June 1922, they made 1,200 arrests and seized 625 stills. ${ }^{136}$ In his 1925-1926 report, Prohibition Commissioner Ross Well labeled the years between 1919 and 1925 as "the "Moonshine Period." He went on to claim that "persistent and systematic application of the law in every section of the state had by the close of 1924 largely suppressed 'moonshining,' and this form of violation continues on a much smaller scale than formerly."137

\footnotetext{
133 The 1918 Year Book of the United States Brewers' Association (New York: United State Brewers' Association Publishing, 1919), 109.

${ }^{134}$ Stewart, Moonshiners and Prohibitionists, 217.

${ }^{135}$ Department of Public Safety Report to the Governor, December 1, 1920, Jason Arnold, Superintendent, in Public Documents, West Virginia, 1919-1920, Volume One (Charleston, WV: Tribune Printing, n.d.), 4.

${ }^{136}$ Fourth Biennial Report of Commissioner Brown, 18-19.

${ }^{137}$ Sixth Biennial Report of the State Commissioner of Prohibition of West Virginia for the Fiscal Years 1925-1926, Ross Wells, State Commissioner of Prohibition in Public Documents, West Virginia, 1925-1926, Volume Four (Charleston, WV: Tribune Printing, n.d.), 8.
} 
Commissioner Wells was delusional. Illicit distilling still overwhelmed state agents in the late 1920s. The Department of Prohibition seized 628 stills during fiscal years 1928 and 1929 and 629 between 1929 and 1930. During this three-year period, only five counties (Gilmer, Hancock, Monroe, Preston, and Tyler) went without a still confiscation by a prohibition agent. ${ }^{138}$ Moonshining remained as common as it was widespread throughout West Virginia at the end of the 1920s. Prohibition, state or national, was not working in the Mountain State. According to Cashman, "Prohibitionists had a choice of alternative responses to a difficult situation: either to recognize that the problems were part and parcel of prohibition and could only be pursued by proper enforcement or to assume the problems were temporary setbacks." ${ }^{" 139}$ West Virginia drys chose the latter. While teetotalers in other parts of the country could no longer blame bordering wet states for the ineffectiveness of dry laws and decided to blame immigrants, Mountain State prohibitionists laid the failure of state and federal prohibition at the feet of law enforcement. ${ }^{140}$

Almost every person or organization with an interest in the Yost Law chimed in on why prohibition violations occurred. West Virginia ASL Superintendant O.M. Pullen claimed in a 1923 letter to Governor Morgan that prohibition "is effective in direct proportion to the honesty and integrity of the officials charged with its enforcement, and in every case where prohibition is a failure this condition is directly traceable to the inefficient, unsympathetic, antagonistic, and crooked [his emphasis] officers." ${ }^{\text {141 }}$ The Methodist Episcopal (ME) Church also questioned the

\footnotetext{
${ }^{138}$ Eighth Biennial Report of the State Commissioner of Prohibition of West Virginia for the Fiscal Years 1929-1930, W.G. Brown, State Commissioner of Prohibition in Public Documents, West Virginia, 1929-1930, Volume Five (Charleston, WV: Jarrett Printing, n.d.), 12-13.

${ }^{139}$ Cashman, Prohibition, 143-144.

${ }^{140}$ Cashman, Prohibition, 144.

${ }^{141}$ Pullen to Morgan, undated (c. 1923), E.F. Morgan Papers, Box 22, West Virginia and Regional History Collection, West Virginia University, Morgantown, WV.
} 
integrity of West Virginia officials during their 1922 conference. As members of the temperance committee resolved, "Realizing the laxity on the part of many of our state officials in the enforcement of the statutes pertaining to prohibition and other laws, we urge them to do their sworn duty, and urge our people to heartily cooperate with them in the performance of the same." ${ }^{142}$ Governor Morgan called on the people of West Virginia to help plug the law enforcement dam in 1923. He commented that "those who advocate the maintenance of law and order should realize that it is their duty to support the law, which implies more than simply obeying it. It is the moral duty of every good citizen not only to obey the law, but to assist in its enforcement." 143

Lockard claims that "the law was in the hands of capable, efficient, and sincere men. On the whole, it was well enforced." 144 While some prohibition officials were indeed honest, Lockard was overstating the situation. Even when agents properly enforced the national and state liquor proscription laws, multi-layered bureaucratic inefficiencies hamstrung their efforts. Too many officials from too many different offices attacked the illicit liquor trade at the same time. Because of the combination of the state Yost Law and the federal amendment, law enforcement at different levels had to cooperate. Unfortunately, as Hamm asserts, "Not many drys seemed to realize that the doctrine of cooperative exercise of state and national power over liquor, which had so long been part of their movement, could lead to lax or no enforcement of the amendment and help to contribute to the collapse of national prohibition." ${ }^{145}$

\footnotetext{
${ }^{142}$ Minutes of the West Virginia Conference of the Methodist Episcopal Church Held in First ME Church, Fairmont, West Virginia, September 27 to October 2, 1922 (Parkersburg, WV: Scholl Publishing Company, c. 1922), 55.

${ }^{143}$ First Biennial Message of Morgan, 22.

${ }^{144}$ Lockard, "The Temperance Movement," 41.

${ }^{145}$ Hamm, Shaping the Eighteenth Amendment, 255.
} 
Department of Prohibition, State Police, Federal, and local officers all targeted liquor violators at the same time in West Virginia. While arrest records suggest that there was some coordination between these overlapping agencies, the most common type of Prohibition Department action was unilateral. Between 1929 and 1930, for example, state prohibition agents made 4,838 arrests. Of these, 1,589 were made by the department with no assistance from other agencies. The next most common circumstance was a shared collar between prohibition and county or municipal officers. ${ }^{146}$ In 1923, the Commissioner of Prohibition Brown openly criticized the lack of enforcement coordination. He admitted that "it is a matter of regret that there has not been the cooperation between this department and that of the Department of Public Safety that was evidently intended by our law makers, and that our citizens have a right to expect." ${ }^{\prime 147}$ Even when there was interdepartmental cooperation, the sheer volume of antiliquor legislation made accurate enforcement that much more difficult. Brown also pointed out to the governor that "the frequent changes in our law have made it very difficult for the local officers to know, with certainty, just what the law was at any given time, much less the average citizen. ... I found, soon after assuming my duties as Commissioner, that local officers as a rule were amazingly ignorant of its provisions."

Much like the law enforcement officials of today who are charged with enforcing prohibitory drug measures, prohibition agents often found themselves outmanned and outgunned in the Mountain State. Moonshiner violence against government authority was certainly not a new condition in the 1920s. During the late nineteenth century, "resistance to enforcement of the

\footnotetext{
${ }^{146}$ Eighth Biennial Report of the State Commissioner of Prohibition, 13.

${ }^{147}$ Annual Report from State Commissioner of Prohibition for Fiscal Years 1922-1923, 26, in E.F. Morgan Papers, Box 29, WVRHC.

${ }^{148}$ Annual Report from State Commissioner, 1922-1923, 3.
} 
federal whiskey tax culminated in whitecapping - vigilante violence directed at federal revenue agents."149 In his 1927 address to the Legislature, Governor Howard Gore detailed the dangers of Yost Law enforcement. According to Gore, "It is a matter of record in our State Police Department that fully ninety per cent of the operators of moonshine stills and a very large per cent of the rum runners are armed." 150 State prohibition deputies were susceptible to particularly vicious attacks by illicit distillers. In one case, "a miniature coffin . . f filled with cartridges of several calibers, was found by L.D. Cradle near his home at Abney. Fixed to the coffin was a note which read, 'Thou shalt not bear witness.' Cradle took the find as a warning to him, for he had been waging a war against moonshiners and bootleggers in his vicinity."151

Threatened violence spilled over to real vigilantism around and during the 1920s. Even before the advent of the State Department of Prohibition, moonshiners murdered an officer while he was in bed sleeping with his wife. ${ }^{152}$ Three years later, a state prohibition agent fell to an assassin's bullet in Wayne County while waiting for a train to the county courthouse. Officials speculated that he "was probably shot because of his activities in trying to curb the making of liquor in this county."153 These conditions, along with the corruption and inefficiency inherent to the liquor proscription system, made prohibition a farce. According to Link, "By the early 1920s it had become clear that the new moral policy of southern state governments, embodied in

\footnotetext{
${ }^{149}$ Link, The Paradox of Southern Progressivism, 312.

${ }^{150}$ First Biennial Message of Governor Howard Gore to the Legislature of 1927 (Charleston, WV: Tribune Printing, 1927), 15.

${ }^{151}$ Charleston Daily Mail, July 15, 1922.

${ }^{152}$ Charleston Daily Mail, August, 12, 1919.

153 Wayne County News, February 16, 1922; the Officer Down Memorial Page website lists seven prohibition agents killed in the line of duty - www.odmp.org/agency/5583-west-virginia-department-of-prohibition-west-virginia.

This is not an exhaustive list.
} 
prohibition, was a failure. ... Moral reformers learned that rallying public opinion against alcohol was one thing, and that enforcing prohibition was entirely another."154 One "aged citizen of Colonial ancestry" reminded Governor Morgan that prohibition "enforcement is impossible." According to the man, "enforcement methods - however gratifying to tyrannous fanatics, to salaried reformers, to bribe-takers and to money making illicit sellers - can only increase the antagonism to prohibition. ... In conclusion, let it be said that against such wide-spread antagonism the Volstead [Federal] law can never be really enforced - not even if the entire army or navy are turned against the people."

West Virginia did not have use of the army or navy. The State Department of Prohibition employed only twelve deputy commissioners at $\$ 2,400$ a year by $1926 .^{156}$ Of course, these twelve deputies were not the only officials attempting to enforce the prohibition law. While other departments prosecuted violators and the 1921 legislature granted the Prohibition Department the "authority to summon ... any male citizen of the county who has attained the age of twenty-one years, to aid and assist in making an arrest or raid," it was never enough. ${ }^{157}$ Federal officials and especially their dry allies, faced with America's return to normalcy in the 1920s, were "unwilling to admit the [enforcement] problems at all and reluctant to ask for additional appropriations for enforcement at a time government was cutting back on expenditures generally."

\footnotetext{
${ }^{154}$ Link, The Paradox of Southern Progressivism, 321; the author provides a detailed discussion of prohibition enforcement efforts in Virginia in chapter 10.

155 "An aged citizen" to Morgan, undated (c. 1923), E.F. Morgan Papers, Box 22, WVRHC.

${ }^{156}$ Sixth Biennial Report of the State Commissioner of Prohibition, 52.

${ }^{157}$ Acts of the Legislature of West Virginia, 1921, 413-414.

${ }^{158}$ Cashman, Prohibition, 143.
} 
In spite of problems with their dry laws, prohibitionists remained politically powerful in the late 1920s. Effectively, groups like the ASL looked good while enforcement went poorly. Dry power in West Virginia peaked in 1928 and early 1929. In a 1928 letter to League headquarters, state ASL Superintendant O.M. Pullen bragged that "the United States Senator, all six of our Congressmen, all the state officers, including the state senators elected, are dry. ... The most sweeping dry and moral victory ever won in West Virginia in the 25 years of experience in public life was that one of last Tuesday."159 The Women's Christian Temperance Union (WCTU) also experienced a surge in influence during the 1920s. As historian Barbara Howe observes, "'By 1927, there were seventy-eight unions in the state and 6290 members."160 Teetotaler politicians exercised this enormous political power during the 1929 legislative session. They passed what the Charleston Gazette described as a "bone-dry" adjustment to the Yost Law by an overwhelming margin. The measure banned malt extracts and made possession of distilling equipment a crime. ${ }^{161}$ Delegate Hill of McDowell County, one of the eight representatives who voted against the bill, expressed his concerns over the growing power of prohibition and law enforcement officials in the Mountain State. According to Hill, "This bill will give grafters, thugs and murderers an additional excuse to prey upon the poor and defenseless people of our state, to break down their doors, smash their furniture and to insult, abuse, beat and murder them."162

\footnotetext{
${ }^{159}$ Pullen to Ernest Cherrington, November 8, 1928, Temperance and Prohibition Papers of the ASL - West Virginia Miscellaneous, Box 2 (Roll 4), Anti Saloon League Collection, Westerville Public Library, Westerville, $\mathrm{OH}$.

${ }^{160}$ Barbara J. Howe, “West Virginia Women's Organizations, 1880s-1930 or 'Unsexed Termagants... Help the World Along,"” West Virginia History 49 (1990): 3. Accessed on www.wvculture.org (October 16, 2009).

${ }^{161}$ Charleston Gazette, March 7, 1929.

162 Journal of the House of Delegates of the State of West Virginia for the $39^{\text {th }}$ Regular Session, Commencing January 9, 1929 (Charleston, WV: Mathews Printing and Lithographing Company, 1929), 880-881.
} 
While West Virginia antiliquor interests were undoubtedly aware of wet concerns, they believed they had the unassailable political power to trump them. As historian K. Austin Kerr points out, "After the dry forces struck what they thought was a deadly and permanent blow to the liquor traffic, they were able to maintain a façade of enormous and virtuous political power." ${ }^{\text {"63 }}$ The West Virginia ASL believed they had confirmed this power with Herbert Hoover's landslide victory over Al Smith in 1928. The headline, "Hoover and Prohibition Victorious: Prohibition Wins in Nation-wide Referendum," greeted readers of the American Issue in November of 1928. Editors opined that "the one dominate [sic] issue in this campaign was prohibition. Governor Smith himself so considered it and pinned his hopes to it." ${ }^{\text {164 }}$ This powerful façade came crumbling down along with the stock market in the fall of 1929. Kerr states that "Hoover and Republicans were blamed for the collapse of the American economy. When the Democrats swept into office after 1930 the dry legislative support evaporated, public support for prohibition seemed to be dying, and the repeal movement raged though most of the nation like a prairie fire." 165

In West Virginia, the crash fundamentally reshaped the legislature overnight. During the 1929 session, the GOP enjoyed a sixty-three to thirty-one edge in the House of Delegates and a twenty-four to six advantage in the state senate. By 1931, Democratic delegates outnumbered Republicans sixty-eight to twenty-six, and the Democratic Party retook senate control (twenty-

\footnotetext{
${ }^{163}$ K. Austin Kerr, Organized for Prohibition: A New History of the Anti-Saloon League (New Haven, CT: Yale University Press, 1985), 10.

${ }^{164}$ American Issue (West Virginia Edition), November, 1928, 1.

${ }^{165}$ Kerr, Organized for Prohibition, 11.
} 
four to six) by 1933. ${ }^{166}$ Republican Governor William Conley’s job remained safe until 1933 since he had assumed office several months before the crash. ${ }^{167}$ Conley fought for the Yost Law even as the political winds began to blow against him. At a speech to the West Virginia ASL in 1929, the governor reminded members that, during his inaugural address he had spoken in favor of prohibition. Conley quoted himself as saying that "I am not one of those who believe that dry enforcement is a failure... The prohibition laws are no longer an experiment. Crime cannot be permitted to break down and force the repeal of laws violated." ${ }^{\prime 68}$ The governor put his words into action when he vetoed a medicinal whiskey bill passed by the 1932 extra session. Conley deemed the bill, passed in order "to raise revenue," unconstitutional primarily because the West Virginia Constitution forbade the extra legislature "from transacting any 'business' except that stated in the proclamation by which it was called together.",169

Legislators, now mostly from the opposition party, ignored the governor's concerns. Both chambers overrode Conley’s veto. ${ }^{170}$ Things got progressively worse for West Virginia teetotalers in the late 1920s and early 1930s. The WCTU experienced a precipitous drop in membership around the turn of the decade. According to Howe, "even before national prohibition ended, membership began to decline. With the onset of the Depression, members could no longer afford the dues. Once the decline started, it became an avalanche. By 1938, the

\footnotetext{
${ }^{166}$ Legislature of West Virginia: Manual of the Senate and House of Delegates, Seventy-Eighth Legislature, 20072008 (Beckley, WV: BTW Printing and Office Supplies, 2008), 325.

167 John G. Morgan, West Virginia Governors, 1863-1980 (Charleston, WV: Charleston Newspapers, 1981 ), 129 and 139.

${ }^{168}$ Quoted in State Papers and Public Addresses of William Conley, Governor, March 4, 1929 to March 4, 1933 (Charleston, WV: Jarrett Printing, n.d.), 62-63.

${ }^{169}$ State Papers and Public Addresses of Conley, 368.

${ }^{170}$ Acts of the Legislature of West Virginia, Regular and Extraordinary Session, 1933 and Extraordinary Session, 1932 (Charleston, WV: Allied Printing, n.d.), 31.
} 
WVWCTU had only seven hundred members." ${ }^{\text {171 }}$ The ASL also experienced growing concerns over its finances and an erosion in subscriptions (membership) during the 1920s. In a letter to Superintendant Pullen, Earnest Cherrington warned that "since 1928 . . we have been facing an increasingly difficult financial situation and now discover that an important factor in that matter has been the dwindling of old subscriptions." Cherrington went on to admit that "we have had the most difficult financial problem in 1930 that we have had since national prohibition was adopted." ${ }^{172}$

State officials also faced the well-coordinated and widespread dissemination of antiprohibition propaganda during the twenties and early thirties. Lockard argues that this "insistent campaign on the part of liquor interests to undermine the state enforcement act" was one of the main reasons that more and more West Virginians turned against prohibition. ${ }^{173}$ Govenor Conley agreed. In his 1931 legislative message, Conley lamented the influence of wet messaging. According to the governor, "Propaganda against prohibition is reaching the public mind through every available avenue. ... Criticism is directed against the Department of Prohibition from a number of sources, including individual citizens and organized groups of citizens, who would have West Virginia retrace her steps." The state, in an effort to turn back this wet onslaught, commissioned its own "campaign of education," published a Prohibition Department bulletin, and reauthorized scientific temperance instruction in schools in $1927 .{ }^{174}$

\footnotetext{
${ }^{171}$ Howe, "West Virginia Women's Organizations," 3.

${ }^{172}$ Cherrington to Pullen, July 23, 1931, ASL Collection, Westerville Public Library.

${ }^{173}$ Lockard, "The Temperance Movement," 43.

${ }^{174}$ Second Biennial Message of Governor William Conley to the Legislature of 1931, January 14, 1931 (Charleston, WV: Jarrett Printing, n.d.), 23-24; Lockard, "The Temperance Movement," 41.
} 
According to Prohibition Commissioner Brown in the 1930 bulletin, "The Association Against the Prohibition Amendment, the 'Rational League of America' and some thirty or more allied organizations are quietly engaged in almost every locality in the state. . . Prohibition is assailed on the editorial page of every newspaper that can be mustered into the fight."175 The Charleston Gazette had certainly been mustered into the anti-proscription fight by the end of the 1920s. Editors reprinted a Morgantown Press editorial that claimed "there are new stories published in various cities telling about high school boys and girls buying moonshine liquor at certain business establishments. ... This nation needs temperance, but more and more it appears prohibition cannot and will not bring about such a condition."176 It appears that, by 1929 , protection of children was not the exclusive rhetorical domain of American prohibitionists. Gazette editors also advanced the wet contention that prohibition laws led to widespread violence and violations of civil liberties. According to the Democratic daily, "We read a good deal in the papers these days of prohibition officers who run up and down the land shooting innocent persons, searching cars in which no liquor is found, illegally invading homes and in general playing hob with the already threadbare bill of rights." 177

By 1930, this wet messaging began to work in the Mountain State. The Literary Digest commissioned prohibition polls in 1930 and 1932 to gauge American attitudes towards liquor proscription. The 1930 poll showed that over 69 percent of citizens favored either repealing or modifying prohibition to allow wine and beer sales. About 62 percent of West Virginians voted

\footnotetext{
${ }^{175}$ State Department of Prohibition Bulletin, September to October, 1930 (Charleston, WV: Jarrett Printing Company, n.d.), 2 in Temperance and Prohibition Papers of the ASL - West Virginia Miscellaneous, Box 2 (Roll 4), ASL Collection, Westerville Public Library.

${ }^{176}$ Morgantown Press, quoted in Charleston Gazette, March 4, 1929.

${ }^{177}$ Charleston Gazette, March 6, 1929.
} 
for repeal or modification. ${ }^{178}$ This anti-prohibition tsunami only grew larger in 1932 as over 73 percent of Americans polled in favor of outright repeal. Over 65 percent of Mountain State residents agreed that it was time to end prohibition. ${ }^{179}$ The writing was on the wall in West Virginia. Most citizens had tired of the prohibition experiment. By 1933, their elected representatives began to carry out the peoples' anti-proscription sentiment. The Legislature authorized a bill legalizing beer of less than 3.05 percent alcohol on the last day of the session. ${ }^{180}$ Governor Herman Guy Kump, who vowed to veto "measures only in clear contravention of the constitution or fixed policy of the administration," allowed the legislation to pass without his signature. ${ }^{181}$ Politicians intended the beer bill to be a revenue enhancer in the midst of a state financial crisis. According to its supporters, "Revenue aggregating more than $\$ 1,000,000$ is expected."182

The 1933 session went much further than simply legalizing weak beer. Solons authorized a referendum on repeal of the state prohibition law to be held during the 1934 general election. ${ }^{183}$ Legislators also provided for "a special election on June 27 [1933] to select delegates to a state convention on repeal of the eighteenth amendment." ${ }^{184}$ The entire prohibition system in the Mountain State was now imperiled. On the eve of the special election, dry leaders doubted

\footnotetext{
${ }^{178}$ Herbert Treadwell Wade, ed., The New International Year Book: a Compendium of the World's Progress for the Year 1930 (New York: Dodd, Mead and Company, 1931), 650.

${ }^{179}$ Frank H. Vizetelly, ed., The New International Year Book: a Compendium of the World's Progress for the Year 1932 (New York: Funk and Wagnalls Company, 1933), 696.

${ }^{180}$ Charleston Gazette, March 12, 1933.

${ }^{181}$ Charleston Daily Mail, March 14, 1933; Wheeling Intelligencer, March 18, 1933.

${ }^{182}$ Wheeling Intelligencer, March 18, 1933.

${ }^{183}$ Huntington Herald-Dispatch, March 10, 1933.

${ }^{184}$ Charleston Gazette, March 11, 1933.
} 
"President Roosevelt's promises of tax relief in repeal of the eighteenth amendment." According to the Huntington Herald-Dispatch, however, "The Anti-Saloon League leader [F. Scott McBride] insists the liquor traffic is taking advantage of the nation's economic distress to exploit the drink traffic. There are many who believe the Anti-Saloon League took advantage of the war-time hysteria to exploit the prohibition cause. To their way of thinking this makes it fiftyfifty as regards exploitation." 185 John F. Woods of the Central Labor Union was one of many to support the eighteenth amendment's repeal. He argued in a radio speech that "labor is first interested in the repeal of the $18^{\text {th }}$ amendment from an economic standpoint. ... We feel that these [high and regressive income] taxes are in a large measure necessitated because the different units of government are deprived of revenue through the $18^{\text {th }}$ amendment." ${ }^{\text {,186 }}$

On Election Day, the majority of West Virginians sided with repeal of national prohibition. Citizens rejected the eighteenth amendment 218,638 to $136,552 .{ }^{187}$ Newspapers attempted to frame the wet vote in geographic and socioeconomic terms. According to the New York Times, "The repealists gained as ballots from the industrial centres rolled in, offsetting the staunch prohibition stand of the hill dwellers and farmer folk in the less populous areas." 188 While more urban counties tended to grant heavier majorities, this urban-rural explanation was not entirely accurate. Historian David Kyvig points out that 58 percent of residents from outside West Virginia's urban areas voted for repeal. ${ }^{189}$ A year and a half later, West Virginians repealed the Yost Law during the 1934 election. Citizens gave state prohibition the boot by a

\footnotetext{
${ }^{185}$ Huntington Herald-Dispatch, quoted in Charleston Gazette, June 2, 1933.

${ }^{186}$ Quoted in Huntington Herald-Advertiser, June 25, 1933.

${ }^{187}$ Lockard, "The Temperance Movement," 50-51.

${ }^{188}$ New York Times, June 28, 1933.

189 David E. Kyvig, Repealing National Prohibition (Chicago: University of Chicago Press, 1979), 179.
} 
majority of nearly $40,000 .{ }^{190}$ The dry era in the Mountain State was over. As one citizen opined on the eve of the 1933 national repeal vote, however, "Intelligent thinkers recognize, however, that the important question is not: 'Shall I vote for repeal?' but: 'If the amendment is repealed, what are we going to have?' No one seems, however, to know the answer to this question."191 As the Mountain State faced its first winter without prohibition, even the state's leadership was not entirely sure. The system that they erected, while designed to operate as a halfway measure between prohibition and intemperance, would eventually presage West Virginia's growing economic dependence on vice.

${ }^{190}$ The vote was approximately 276,000 to 238,000; Lockard, "The Temperance Movement," 52-53.

${ }^{191}$ Quoted in Huntington Herald-Dispatch, June 23, 1933. 


\section{CONCLUSION AND EPILOGUE}

West Virginia imposed state prohibition on its citizens on July 1, 1914. While the transition to a dry society was relatively quiet in the days leading up to July 1 , this tranquility belied the sixty-year battle waged between Mountain State "wets" and "drys" over liquor proscription. Beginning in the 1850 s among evangelical Protestants, the anti-liquor movement pushed for different levels of alcohol proscription. By the 1880s, drys were agitating for a state prohibitory amendment to the West Virginia Constitution. The legislative efforts of these preprogressive activists failed on multiple occasions. This political disappointment peaked with the statewide rejection of a prohibition referendum in 1888. In short, while teetotalers were able to secure local and county-level prohibition via ordinances and commission elections and chip away at the saloon trade through incremental adjustments to state liquor law, West Virginia was not yet ready to climb aboard the water wagon.

Around the turn of the twentieth century, Mountain State drys had activated a more sophisticated and well-funded propaganda campaign. The key to this development was the founding of the West Virginia Anti-Saloon League. Better organization was not enough, however, to explain why West Virginians would eventually authorize state liquor proscription in 1912. The Mountain State also experienced a rapid form of industrialization that changed its socioeconomic and political environment. These changes enhanced a philosophical shift from a laissez-faire, Gilded Age sensibility defined by intense political and social localism to an outlook more closely aligned with Progressive-era activism. In other words, before the turn of the twentieth century, West Virginians accepted localized liquor proscription, but tended to avoid more bureaucratic or statewide anti-alcohol fixes. Once industrialization hit and progressivism 
seeped in, however, Mountain State residents were more likely to accept the idea of imposing their beliefs on their neighbors.

In 1912, West Virginia voters overwhelmingly authorized a constitution amendment providing for statewide prohibition. Unfortunately for drys, in spite of their best efforts at closing off loopholes and plugging the dam, the Mountain State was never as dry as the Yost Law dictated. Bureaucratic inefficiency, corruption, and widespread illicit distilling delegitimized the law in the eyes of many West Virginians. By the time progressivism waned and America entered the Great Depression, most Americans - Mountain State citizens included wanted state and federal prohibition to go away. West Virginians repealed national prohibition in 1933 and the Yost Law in 1934.

The rise and fall of state prohibition in West Virginia lends valuable insight and complexity to many of the Mountain State's post-bellum social, economic, and political struggles. "Vending Vice" is the story of the temporary victory of northern industrialization and centralized bureaucracy over southern Bourbon Democracy and localism. This tension existed in numerous states during the industrial period, but it was especially noticeable in West Virginia. It is also the story of socioeconomic change and upheaval, and the defensive imposition of middleclass, Protestant values over an increasingly diverse population. In the end, though, it is the story of the breakdown of the progressive impulse after World War I, the collapse of the post-war economy, and the gradual acceptance by most West Virginians - and their government - that liquor can be more than simply a social evil. This dissertation ends with the repeal of prohibition in 1934, but struggles over alcohol and vice did not end in 1934.

The new liquor control section of the West Virginia Constitution read: "The Legislature shall by appropriate legislation regulate the manufacture and sale of intoxicating liquors within 
the limits of this State, and any law authorizing the sale of such liquors shall forbid and penalize the consumption and the sale thereof for consumption in a saloon or other public place." According to legal scholar Robert Bastress, a 1935 state court decision (State v. McClung) determined that the clause "leaves the question of the extent to which liquor will be permitted to legislative discretion: The legislature may ban it entirely, tightly control it, or allow abroad distribution." ${ }^{\prime 1}$ This flexibility led to considerable debate when legislators convened in 1935 to erect a liquor control structure. Some solons wanted an open license system and others favored a state-run monopoly. Senator Luther Jones pushed a plan that would "call for a state monopoly of wholesale liquor sales and for an open license system of retail sales." Jones argued "that the only way to rid the state of the bootlegger is to make liquor easily attainable by all who want it." Governor Kump advanced another plan. In his 1935 message to the legislature, Kump argued that "in my opinion there is no satisfactory solution to the liquor problem.... The best that is possible is to limit and control excessive use, and to shield our people from the sinister influence of intemperance. ... May I emphasize this thought: the state must control the liquor traffic, or the liquor traffic will control the state."3

Some Mountain State residents worried that the governor's plan to set up a state monopoly of liquor sales would lead to political corruption. One Williamson hotel owner argued that "it has been said on all sides that a state monopoly, with its retail stores plan, can be built into a powerful political machine, I do not believe we want to do that. As a matter of fact over in

\footnotetext{
${ }^{1}$ Robert M. Bastress, The West Virginia State Constitution: A Reference Guide (Westport, CT: Greenwood Press, 1995), 173.

${ }^{2}$ Charleston Gazette, January 19, 1935.

${ }^{3}$ Quoted in John G. Morgan, West Virginia Governors, 1863-1980 (Charleston, WV: Charleston Newspapers, 1981), 145.
} 
Mingo County machines get so rotten about every eight years that they are turned out of office."4 Ultimately, Kump's preferred scheme won out and the legislature passed his state monopoly system on February 22, $1935 .^{5}$ The new measure's wording suggested that state officials wanted it both ways. They wanted legalized liquor, but they wanted to limit and control access to it. Legislators designed the system "to assure the greatest degree of personal freedom that is consistent with the health, safety, and good morals of the people of the state." ${ }^{\circ}$ This stated goal embodied an instructive mixture of latent prohibitionist calls for "good morals" and antiprohibitionist "personal freedom." Regardless of the competing social visions behind the state monopoly plan, West Virginia quickly built an impressive system of state-run liquor stores. According to the first Liquor Control Commission report, "there were ' 62 stores open from May 9 through August 9, 1935, as well as two agencies,' or non-public distribution centers."7

The Mountain State suddenly found itself in the business of vending vice, and business was good. According to E. Kidd Lockard, "The financial benefits of the plan have been large. Since the law became effective March 1, 1935 until November 30, 1936 the profit realized was $\$ 3,755,939.39$ from sales totaling $\$ 14,730,608.09$ at 86 stores and agencies and $\$ 273,383.62$ from manufacturers' licenses." ${ }^{8}$ A revenue stream like this would have been unthinkable just a few years earlier. Prohibition, after all, was thought to be good for the economy in the period before the Depression. When wet politicians argued that a national prohibitory system "would

\footnotetext{
${ }^{4}$ Wheeling Intelligencer, January 30, 1935.

${ }^{5}$ Charleston Gazette, February 23, 1935.

${ }^{6}$ Quoted in Joseph Platania, “West Virginia's State Stores: A Legacy of Prohibition,” Goldenseal 25 (Spring 1999): 47.

${ }^{7}$ Platania, “West Virginia's State Stores," 47.

${ }^{8}$ E. Kidd Lockard, “The Temperance Movement in West Virginia” (MA thesis, West Virginia University, 1937$), 44$.
} 
destroy about one-third of the federal revenue and lead to a corresponding increase of general taxation," then, most citizens did not take heed. As James Timberlake asserts, "National prosperity, together with the federal income tax and other sources of revenue opened up by the war, promised to more than offset the loss." ${ }^{9}$ In fact, dry activists leaned more and more heavily on the perceived financial perks of liquor proscription in the 1920s. According to David Kyvig, "Indeed, with enforcement more difficult than expected, they cited prohibition's economic benefits as a major justification for maintaining it. . . Right up to the moment of collapse, both prohibition advocates and the unsympathetic attributed prosperity to the influence of the liquor ban."10

Understandably, these economic arguments became less and less compelling as America sank further and further into the Depression. After the collapse, "the tables were turned, and the claims of prohibition's effect on the economy were used against the law." Members of the antiprohibition movement asserted that it was harmful and unfair to tax recovering industries at high rates when large amounts of revenue could be extracted from the liquor trade. ${ }^{11}$ West Virginia politicians actively applied these anti-prohibition arguments in 1933 and 1935 with the legalization of beer and the authorization of the state store liquor monopoly. While state solons may have ostensibly passed these bills to cut down on bootlegging and protect the "good morals" of the state, they were really easy revenue enhancers in a time of economic dislocation. The 1933 legislature also legalized horse racing. Legislators specifically designed the measure to raise funds for the state. As the Charleston Daily Mail reported, "Described as a revenue

\footnotetext{
9 James H. Timberlake, Prohibition and the Progressive Movement (Cambridge, MA: Harvard Press, 1963), 176.

${ }^{10}$ David E. Kyvig, Repealing National Prohibition (Chicago: University of Chicago Press, 1979), 130-131.

${ }^{11}$ Kyvig, Repealing National Prohibition, 131 and 133.
} 
measure, the [horse racing] bill levies a tax of 10 per cent of the money bet." ${ }^{\prime 2}$ When considered in the long duration, the crash and subsequent legislative reactions emerge as the turning points in West Virginia's political and economic attitudes toward and expectations of liquor and other forms of vice. The actions taken by the 1933 and 1935 legislatures are the first examples in the modern history of the Mountain State when politicians, faced with significant economic crises, leaned on vice as economic development - they would not be the last.

Between the end of the Depression and the beginning of the Reagan administration, West Virginia politicians faced a seemingly endless cycle of booms and busts. For the most part, leaders did not establish connections between revenue creation, economic development, and vice. The state made several administrative changes and structural adjustments to its alcohol control authority in the 1950 s and 1960s. ${ }^{13}$ However, political leaders still leaned on non-vice revenue plans - liquor and gambling was not yet an option. When West Virginia's economy began to falter in the 1970s, though, leaders like Jay Rockefeller, and later, Arch Moore, began to revisit liquor and gambling as viable means for revenue creation and economic development. ${ }^{14}$ Some would attribute the decision in the 1970s to turn to vice as further evidence of the loosening of American morals. The reason for this new economic direction had more to do with the politics of the time.

The traditional remedy for a crisis like this would have been to increase taxes. State politicians, including Mountain State politicians, were no longer able to fall back on this option alone. Widespread revolts against taxation, in spite of a higher demand for social services

\footnotetext{
${ }^{12}$ Charleston Daily Mail, March 13, 1933.

${ }^{13}$ Platania, “West Virginia's State Stores," 47.

${ }^{14}$ For more on the recession of the 1970s and 1980s, see Thomas F. Stafford, Afflicting the Comfortable: Journalism and Politics in West Virginia (Morgantown: West Virginia University Press, 2005).
} 
cultivated during the 1960 s, swept through America. ${ }^{15}$ If state politicians wanted to raise revenue by the late 1970 s and early 1980 s, they would have to look into other options.

Gambling via state lotteries emerged as a viable way to raise needed revenue without raising the ire of residents and voters. ${ }^{16}$ West Virginia lawmakers opened the floodgates of vice and economic development in 1983 by authorizing a vote on a state lottery. In 1984, over two-thirds of citizens approved the constitutional amendment. ${ }^{17}$ By 2007, the Mountain State had almost every form of gambling imaginable. As the economy continued to struggle in the late 1980s and early 1990s, West Virginia leaders again decided to liberalize proscriptions on vice. Governor Gaston Caperton decided to privatize liquor sales in $1990 .{ }^{18}$ Caperton's decision to pursue divestiture was one based purely on revenue enhancement. In fact, the profits from the sale of state liquor stores to private industry were "essential to the governor's economic program.",19 The divestiture netted the Mountain State $\$ 26.5$ million in $1991 .^{20}$

Both of these strategies allowed elected officials to raise funds without angering their respective electorates. As political scientists Richard Brisbin and Patrick Pierce argue, "Gambling allowed the generation of necessary new revenue without making politically

\footnotetext{
${ }^{15}$ Patrick A. Pierce and Donald E. Miller, Gambling Politics: State Government and the Business of Betting (Boulder, CO: Lynne Rienner Publishers, 2004), 1-2 and 22; for more on this phenomenon, see Lisa McGirr, Suburban Warriors: Origins of the New American Right (Princeton, NJ: Princeton University Press, 2001) and David O. Sears and Jack Citrin, Tax Revolt: Something for Nothing in California (Cambridge, MA: Harvard Press, 1982).

${ }^{16}$ Pierce and Miller, Gambling Politics, 60. For more detailed information on the rise of legal gambling in West Virginia, see Richard A. Brisbin and Patrick A. Pierce, "Casting the Dice: The Development of Legalized Gambling Policy in West Virginia," The West Virginia Public Affairs Reporter 25 (May 2008): 2-17.

17 Thomas A. Garrett, “An Economic Analysis of State Lotteries in America” (PhD diss., West Virginia University, 1998), 22.

18 Platania, "West Virginia's State Stores," 47.

${ }^{19}$ Wheeling Intelligencer, February 22, 1990.

${ }^{20}$ www.avabca.com
} 
unpopular tax increases that might embolden challengers for their seats." ${ }^{, 21}$ Theoretically, though, liberalized liquor regulations and new forms of gambling like video lottery and casino table games violate the West Virginia Constitution. Just like their prohibitionist forefathers, though, modern-day vendors of vice simply run roughshod over such concerns. The Constitution forbids the public consumption of alcohol. West Virginia lawmakers get around this clause by considering beer nonintoxicating and deeming that loosely defined "private clubs are not saloons or other public places." ${ }^{22}$ The State Constitution also contains a gambling prohibition. Gaming officials in the Mountain State are able to circumvent this proscription because the Court of Appeals ruled "that 'lotteries' [which are legal] should be construed broadly." As long as leaders define advanced gambling services like table games and "hot spots" as lotteries, then, they are not violating the West Virginia Constitution. Similar to the transformation of the anti-saloon Yost Law into a bone-dry prohibition measure, many pro-lottery citizens wonder what they really authorized. As Brisbin and Pierce point out, "Passage of the Lottery Amendment by West Virginia voters in 1984 has had a policy impact far greater than anyone would have thought at the time. ${ }^{.23}$

In the last 150 years, West Virginia has transformed from one of the driest and most prohibitive states in the country to one of the wettest and loosest. The question today is: has the Mountain State swung too far from imposed morality to regressive vice? While they dwell on opposite sides of the question, yesterday's prohibitionists and today's vice vendors share important commonalities. Chief among these is the fact that both groups were willing to

\footnotetext{
${ }^{21}$ Brisbin and Pierce, "Casting the Dice," 15.

${ }^{22}$ Bastress, The West Virginia State Constitution, 173.

${ }^{23}$ Brisbin and Pierce, "Casting the Dice," 5 and 16.
} 
manipulate economic and political circumstances and constitutional frameworks to reach their respective goals. The difference dwells in why they manipulated the system. As K. Austin Kerr argues, "Prohibition was a reform, a version of an uplift sentiment that was widespread during the Progressive era and that extended beyond World War I." Wets had a contrasting goal. Kerr asserts that "when Americans rejected the prohibition reform in 1933, they acted from motives sharply different from the ideals of those reformers who would destroy the liquor traffic in order to foster the improvement of society." 24

Initially, West Virginia citizens rejected prohibition because it did not work. Many Mountain State politicians, on the other hand, saw dollar signs in legalizing beer sales and erecting a state monopoly system. This cynical calculation only continued later in the twentieth century as lawmakers leaned more and more on vice as a convenient way to raise revenue without raising taxes. Rank and file prohibitionists, as nasty as their leadership became towards the end of the dry regime, were at least earnest. They were not trying to save their jobs or wring more money out of their constituents; most truly believed they were making their state and nation a better place. Unfortunately, in West Virginia, it took these activists and their neighbors twenty years to admit that their grand experiment could not work - some never did. How long will it take modern-day vice vendors to realize that, as more and more surrounding states legalize the very same supposedly harmless revenue enhancers, economic development built upon a foundation as shaky as liberalized liquor and gambling is not made to last?

\footnotetext{
${ }^{24}$ K. Austin Kerr, Organized for Prohibition: A New History of the Anti-Saloon League (New Haven, CT: Yale University Press, 1985), 277.
} 


\section{BIBLIOGRAPHY}

\section{Manuscript Collections}

Anti-Saloon League. Temperance and Prohibition Papers of the ASL - West Virginia Miscellaneous. Anti-Saloon League Collection, Westerville Public Library, Westerville, Ohio.

Cornwell, John Jacob. Papers. West Virginia and Regional History Collection, West Virginia University, Morgantown, West Virginia.

Glasscock, William. Papers. West Virginia and Regional History Collection, West Virginia University, Morgantown, West Virginia.

Morgan, E.F. Papers. West Virginia and Regional History Collection, West Virginia University, Morgantown, West Virginia.

Society of the Sons of Temperance, 1851-1856. Minute Books. West Virginia and Regional History Collection, West Virginia University, Morgantown, West Virginia.

White, A.B. Papers. West Virginia and Regional History Collection, West Virginia University, Morgantown, West Virginia.

Women's Christian Temperance Union, 1897-1934. Minutes. West Virginia and Regional History Collection, West Virginia University, Morgantown, West Virginia.

\section{Government Documents}

Acts of the Legislature of West Virginia at its $11^{\text {th }}$ Session, 1872-3. Charleston, WV: Walker Public Printer, 1873.

Acts of the Legislature of West Virginia at its $13^{\text {th }}$ Regular Session, Commencing January 10, 1877. Wheeling, WV: Johnston Public Printing, 1877.

Acts of the Legislature of West Virginia at its $17^{\text {th }}$ Session, Commencing January 14, 1885. Wheeling, WV: Taney Printer, 1885.

Acts of the Legislature of West Virginia at its $20^{\text {th }}$ Regular Session. Charleston, WV: Donnelly Public Printers, 1891.

Acts of the Legislature of West Virginia at its $26^{\text {th }}$ Regular Session. Charleston, WV: Tribune Printing, 1903. 
Acts of the Legislature of West Virginia at its Extraordinary Session, 1904. Charleston, WV: Tribune Printing, 1904.

Acts of the Legislature of West Virginia, Extraordinary Session, 1908. Charleston, WV: Tribune Printing, 1908.

Acts of the Legislature of West Virginia, Thirty-first Regular Session, 1913. www.wvculture.org.

Acts of the Legislature of West Virginia, Regular and Extra Sessions, 1915. Charleston, WV: Tribune Printing, 1915.

Acts of the Legislature of West Virginia, Regular Session, 1917. Charleston, WV: Tribune Printing, 1917.

Acts of the Legislature of West Virginia, Regular Session, 1919. Charleston, WV: Tribune Printing, 1919.

Acts of the Legislature of West Virginia, Regular and Extraordinary Sessions, 1921. Charleston, WV: Tribune Printing, 1921.

Acts of the Legislature of West Virginia, Regular and Extraordinary Session, 1933 and Extraordinary Session, 1932. Charleston, WV: Allied Printing, n.d.

13th Census of the United States, Taken in 1910, Volume I, Population, General Report and Analysis. Washington, DC: Government Printing Office, 1913.

"Biennial Report of the Auditor of West Virginia, 1899-1900, Part One (1899)." In Public Documents of West Virginia, Part One (1900-1901). Charleston, WV: Butler Publishing, 1901.

"Biennial Report of the Auditor of West Virginia, 1911-1912." In West Virginia Public Documents, 1911-1912, Volume One. Charleston, WV: Union Publishing, 1912.

"First Biennial Report of the State Tax Commissioner of West Virginia, Ex-Officio State Commissioner of Prohibition for the Fiscal Years 1915-1916, Fred O. Blue, State Tax Commissioner." In Public Documents, West Virginia, 1915-1916, Volume Two. Charleston, WV: Tribune Printing, 1917.

"Second Biennial Report of the State Tax Commissioner of West Virginia, Ex-Officio State Commissioner of Prohibition for the Fiscal Years 1917-1918, Walter S. Hallanan, State Tax Commissioner." In Public Documents, West Virginia, 1917-1918, Volume Two. Charleston, WV: Tribune Printing, 1918.

"Fourth Biennial Report of the State Commissioner of Prohibition of West Virginia for the Fiscal Years 1921-1922, W.G. Brown, State Commissioner of Prohibition.” In Public 
Documents, West Virginia, 1921-1922, Volume Two. Charleston, WV: Tribune Printing, n.d.

"Sixth Biennial Report of the State Commissioner of Prohibition of West Virginia for the Fiscal Years 1925-1926, Ross Wells, State Commissioner of Prohibition." In Public

Documents, West Virginia, 1925-1926, Volume Four. Charleston, WV: Tribune Printing, n.d.

"Eighth Biennial Report of the State Commissioner of Prohibition of West Virginia for the Fiscal Years 1929-1930, W.G. Brown, State Commissioner of Prohibition." In Public Documents, West Virginia, 1929-1930, Volume Five. Charleston, WV: Jarrett Printing, n.d.

"Department of Public Safety Report to the Governor, December 1, 1920, Jason Arnold, Superintendent." In Public Documents, West Virginia, 1919-1920, Volume One. Charleston, WV: Tribune Printing, n.d.

Dillon, JC., ed. West Virginia Blue Book, 1976. Charleston, WV: Jarrett Printing, 1976.

Harris, John T., ed. West Virginia Legislative Handbook and Manual and Official Register, 1916 (rev.). Charleston, WV: Tribune Printing, 1916.

Journal of the Senate of the State of West Virginia, 1863. Wheeling, WV: McDermott Printing, 1863.

Journal of the House of Delegates of the State of West Virginia, 1864. Wheeling, WV: McDermott Printing, 1864.

Journal of the Senate of the State of West Virginia, 1864. Wheeling, WV: McDermott Printing, 1864.

Journal of the House of Delegates of the State of West Virginia, 1866. Wheeling, WV: Frew Publishing, 1866.

Journal of the House of Delegates of the State of West Virginia, 1867. Wheeling, WV: Frew Publishing, 1867.

Journal of the Senate of the State of West Virginia, 1870. Wheeling, WV: Frew Printing, 1870.

Journal of the House of Delegates of the State of West Virginia for the Sixteenth Session, 1881. Wheeling, WV: Johnston Printing, 1881.

Journal of the House of Delegates of the State of West Virginia, for the Adjourned Session, 1882. Wheeling, WV: Johnston Publishing, 1882. 
Journal of the House of Delegates of the State of West Virginia for the $18^{\text {th }}$ Session, 1885. Wheeling, WV: Taney Printers, 1885.

Journal of the Senate of the State of West Virginia for the $18^{\text {th }}$ Session, 1885. Wheeling, WV: Taney Printers, 1885.

Journal of the House of Delegates of the State of West Virginia for the $26^{\text {th }}$ Regular Session, Commencing January 14, 1903. Charleston, WV: Tribune Printing, 1903.

Journal of the Senate of the State of West Virginia for the $26^{\text {th }}$ Regular Session, Commencing January 14, 1903. Charleston, WV: Tribune Printing, 1903.

Journal of the House of Delegates of the State of West Virginia for the Extraordinary Session of 1913 and the Thirty-first Regular Session, Commencing January 8, 1913. Charleston, WV: Tribune Printing Company, 1913.

Journal of the Senate of the State of West Virginia for the Extraordinary Session, Commencing January 2, 1913 and the Thirty-first Regular Session, Commencing January 8, 1913. Charleston, WV: Tribune Printing Company, 1913.

Journal of the Senate of the State of West Virginia for the Thirty-Second Regular Session Commencing January 13, 1915 and the Extraordinary Session Commencing February 27, 1915 and May 18, 1915. Charleston, WV: Tribune Printing, 1915.

Journal of the Senate of the State of West Virginia for the $33^{\text {rd }}$ Regular Session, Commencing January 10, 1917 and the Extraordinary Session, Commencing February 24, 1917 and May, 1917. Charleston, WV: Tribune Printing Company, 1917.

Journal of the House of Delegates of the State of West Virginia for the $39^{\text {th }}$ Regular Session, Commencing January 9, 1929. Charleston, WV: Mathews Printing and Lithographing Company, 1929.

Legislature of West Virginia: Manual of the Senate and the House of Delegates, Seventy-Eighth Legislature, 2007-2008. Beckley, WV: BTW Printing and Office Supplies, 2008.

Walker, Francis., ed. A Compendium of the Ninth Census of the United States, June 1, 1870. Washington, DC: Government Printing Office, 1872.

West Virginia Journal and Bills of the Senate, 1881. Wheeling, WV: Public Printers, 1881.

West Virginia Journal and Bills of the House of Delegates, 1883. Wheeling, WV: Public Printers, 1883.

West Virginia Journal and Bills of the Senate, 1883. Wheeling, WV: Public Printing, 1883. 
West Virginia Journal and Bills of the House of Delegates, 1887. Charleston, WV: Public Printing, 1887.

\section{Speeches and Public Addresses}

First Biennial Message of Governor AB White to the Legislature of West Virginia, Session of 1903. Charleston, WV: Tribune Printing, 1902.

Biennial Message of Governor AB White to the Legislature of West Virginia, Session of 1905. Charleston, WV: Tribune Printing, 1905.

Regular Biennial Message of Governor Dawson to the Legislature of 1909. Charleston, WV: News Mail, n.d.

Regular Biennial Message of Governor Glasscock to the Legislature of 1911 Regular Session. Charleston, WV: New-Mail Company, 1911.

Regular Biennial Message of Governor Glasscock to the Legislature of 1913, January 2, 1913. Charleston, WV: Union Printing, 1912.

First Biennial Message of Governor Henry Hatfield to the 1915 Legislature. Charleston, WV: Tribune Printing, 1915.

Second Biennial Message of Governor Henry Hatfield to the 1917 Legislature. n.p., n.d.

Biennial Message of Governor John J. Cornwell to the Legislature of 1919, January 8, 1919. Charleston, WV: Tribune Printing, n.d.

Special Message of Governor John J. Cornwell to the First Extraordinary Session, March 11, 1919. Charleston, WV: Tribune Printing, n.d.

Biennial Message of Governor John J. Cornwell to the West Virginia Legislature, January 12, 1921. Charleston, WV: Tribune Printing, n.d.

First Biennial Message of Governor Ephraim Morgan to the Legislature of West Virginia, 1923. Charleston, WV: Tribune Printing, n.d.

First Biennial Message of Governor Howard Gore to the Legislature of 1927. Charleston, WV: Tribune Printing, 1927.

Second Biennial Message of Governor William Conley to the Legislature of 1931, January 14, 1931. Charleston, WV: Jarrett Printing, n.d.

State Paper and Public Addresses of William Conley, Governor, March 4, 1929 to March 4, 1933. Charleston, WV: Jarrett Printing, n.d. 
Cherrington, Ernest H., ed. The ASL Yearbook: An Encyclopedia of Facts and Figures Dealing with the Liquor Traffic and Temperance Reform, Volume 1 (1908). Columbus, OH: AntiSaloon League Publishing, n.d.

--_--., ed. The ASL Yearbook: An Encyclopedia of Facts and Figures Dealing with the Liquor Traffic and Temperance Reform, Volume 2 (1909). Columbus, OH: Anti-Saloon League Publishing, n.d.

---- ., ed. The ASL Yearbook: An Encyclopedia of Facts and Figures Dealing with the Liquor Traffic and Temperance Reform, Volume 3 (1910). Westerville, OH: American Issue Publishing, n.d. 
., ed. The ASL Yearbook: An Encyclopedia of Facts and Figures Dealing with the Liquor Traffic and Temperance Reform, Volume 4 (1911). Westerville, OH: American Issue Publishing, n.d.

Year Book of the United States Brewers' Association. New York: United States Brewers' Association Publishers, 1909.

Year Book of the United States Brewers'Association. New York: United States Brewers' Association Publishers, 1910.

United States Brewers Association: The Yearbook and Proceedings of the $53^{\text {rd }}$ Annual Convention Held in Atlantic City, NJ, Friday and Saturday, October $3^{\text {rd }}$ and $4^{\text {th }}, 1913$. New York: United States Brewers’ Association Publishing, 1914.

The 1915 Year Book of the United States Brewers' Association, Containing The Reports Delivered at the 55 $5^{\text {th }}$ Annual Convention Held in Springfield, Mass., October 13-16, 1915, and Added Chapters. New York: United States Brewers' Association Publishing, 1915.

The 1916 Year Book of the United State Brewers' Association, Containing The Principle Reports Delivered at the 56 ${ }^{\text {th }}$ Annual Convention Held in Cleveland, Ohio, November 21-24, 1916, and Added Chapters. New York: United Brewers' Association Publishing, 1916.

The 1918 Year Book of the United States Brewers' Association. New York: United States Brewers' Association Publishing, 1919.

\section{Meeting/Conference Minutes}

Minutes of the Fifteenth Annual Session of the Baptist General Association of West Virginia. Parkersburg, WV: Elletson Book and Job Printer, 1879.

Minutes of the Seventeenth Annual Session of the Baptist General Association of West Virginia. Parkersburg, WV: Elletson Book and Job Printer, 1881.

Minutes of the Baptist General Association of West Virginia, Session of 1882, Nineteenth Annual, Held at Hinton, West Virginia. Parkersburg, WV: George Elletson, Printer, 1882.

$20^{\text {th }}$ Annual Session of the Baptist General Association of West Virginia, Held at Charleston, WV, November 6 to 9, 1884. Akron, OH: Beacon Publishing, 1884.

West Virginia Baptist Annual and Proceedings of the $25^{\text {th }}$ Annual Session of the Baptist General Association, Held at Alderson, WV, October 17-20, 1889. Alderson, WV: Argus Printing House, 1889. 
Minutes of the $32^{\text {nd }}$ Annual Meeting of the Baptist General Association of West Virginia, Held in the First Baptist Church in Wheeling, WV, October 14-18, 1896. n.p., n.d.

Minutes of the $34^{\text {th }}$ Annual Meeting of the General Association of West Virginia, Held in the Fairmont Baptist Church, Fairmont, WV, October 12-16, 1898. Huntington, WV: Banner Printing, 1898.

Minutes of the Western Virginia Conference of the Methodist Episcopal Church for the years 1848 to 1857 . n.p., n.d.

Minutes of the West Virginia Annual Conference of the Methodist Episcopal Church, Held at Morgantown, WV, March 21, 1866. Wheeling, WV: Ewing and Company Printers, 1866.

Minutes of the West Virginia Annual Conference of the Methodist Episcopal Church, Held at Fairmont, WV, March 11, 1874. Wheeling: WV: Daily Intelligencer Steam Book and Job Press, 1874.

Minutes of the West Virginia Conference of the Methodist Episcopal Church, Held at Moundsville, WV, October 5-10, 1881. Akron, OH: Beacon Publishing, 1881.

Minutes of the West Virginia Conference of the Methodist Episcopal Church, Held at Clarksburg, WV, October 4-9, 1882. Akron, OH: Beacon Publishing, 1882.

Minutes of the $41^{\text {st }}$ Annual Session of the West Virginia Conference of the Methodist Episcopal Church, Held at Parkersburg, WV, October 5-11, 1887. Morgantown, WV: New Dominion Steam Printing House, 1887.

Official Journal and Minutes of the $43^{\text {rd }}$ Annual Session of the West Virginia Conference of the Methodist Episcopal Church, Held at Point Pleasant, WV, September 18 to 23, 1889. Wheeling: West Virginia Printing Company, 1889.

Official Journal and Minutes of the Forty-Sixth Annual Session of the West Virginia Conference of the Methodist Episcopal Church, Held at Huntington, WV, September 21 to September 26, 1892. Wheeling: West Virginia Printing Company, 1892.

Official Journal and Minutes of the Forty-Eighth Annual Session of the West Virginia Conference of the Methodist Episcopal Church, Held at Charleston, WV, September 12 to September 17, 1894. Wheeling: West Virginia Printing Company, 1894.

Official Journal and Minutes of the Forty-Ninth Annual Session of the West Virginia Conference of the Methodist Episcopal Church, Held at Buckhannon, WV, September 18 to September 24, 1895. Also the Lay electoral Conference. Wheeling, WV: WJ Johnson, Printer and Binder, 1895. 
Official Journal and Minutes of the $57^{\text {th }}$ Annual Session of the West Virginia Conference, Methodist Episcopal Church, Sessions, Held at Wheeling, West Virginia, September 30 to October 5, 1903. Published by the Secretaries, c. 1903.

Official Journal and Minutes of the West Virginia Conference of the Methodist Episcopal Church, $60^{\text {th }}$ Annual Session held at Sistersville, WV, October the third to the eighth, 1906. Published by the Secretaries, c. 1906.

Official Journal and Minutes of the West Virginia Conference of the Methodist Episcopal Church, Sixty-third Annual Session held at Mannington, WV from September the twentyninth to the fourth of October, 1909. Published by the Secretaries, c. 1909.

Official Journal and Minutes of the West Virginia Conference of the Methodist Episcopal Church, Sixty-fifth Annual Session, Held at Charleston, WV from October the fourth to October ninth, 1911. Published by the Secretaries, c. 1911.

Minutes of the West Virginia Conference of the Methodist Episcopal Church Held in First ME Church, Fairmont, West Virginia, September 27 to October 2, 1922. Parkersburg, WV: Scholl Publishing Company, c. 1922.

Minutes of the First Annual Session of the Synod of West Virginia of the Presbyterian Church, Held at Parkersburg, West Virginia, October 18-20, 1904. Morgantown, WV: Acme Publishing, 1904.

Annual Reports of the Women's Christian Temperance Union, West Virginia, 1886-7-8. Keyser, WV: Mountain Echo Printers, 1888.

Minutes of the $18^{\text {th }}$ Annual Convention of the Women's Christian Temperance Union West Virginia, 1900. Fairmont, WV: Union Printing, 1900.

\section{Books}

Bastress, Robert M. The West Virginia State Constitution: A Reference Guide. Westport, CT: Greenwood Press, 1995.

Blocker, Jack S. Retreat from Reform: The Prohibition Movement in the United States, 18901913. Westport, CT: Greenwood Press, 1976.

Blue, Frederick O. When a State Goes Dry: A Brief Study in Law Enforcement. Westerville, OH: American Issue Press, 1916.

Bordin, Ruth. Woman and Temperance: The Quest for Power and Liberty, 1873-1900. New Brunswick, NJ: Rutgers University Press, 1990.

Cashman, Sean Dennis. Prohibition: The Lie of the Land. New York: The Free Press, 1981. 
Cherrington, Earnest H., ed. The Evolution of Prohibition in the United States of America: A Chronological History. Westerville, OH: American Issue Press, 1920.

Engelmann, Larry. Intemperance: The Lost War Against Liquor. New York: The Free Press, 1979.

Fones-Wolf, Ken. Glass Towns: Industry, Labor, and Political Economy in Appalachia, 18901930s. Urbana: University of Illinois Press, 2007.

Hamm, Richard F. Shaping the Eighteenth Amendment: Temperance Reform, Legal Culture, and the Polity, 1880-1920. Chapel Hill: University of North Carolina Press, 1995.

Johnson, Mrs. Ned. Mountaineer Memories: 1883-1893. Undated Typescript.

Kerr, K. Austin. Organized for Prohibition: A New History of the Anti-Saloon League. New Haven, CT: Yale University Press, 1985.

Kyvig, David E. Repealing National Prohibition. Chicago: University of Chicago Press, 1979.

Lerner, Michael A. Dry Manhattan: Prohibition in New York City. Cambridge, MA: Harvard Press, 2007.

Lewis, Ronald and Ken Fones-Wolf., eds. Transnational West Virginia: Ethnic Communities and Economic Change, 1840-1940. Morgantown: West Virginia University Press, 2002.

Link, William A. The Paradox of Southern Progressivism, 1880-1930. Chapel Hill: University of North Carolina Press, 1992.

McGirr, Lisa. Suburban Warriors: Origins of the New American Right. Princeton, NJ: Princeton University Press, 2001.

Morgan, John G. West Virginia Governors, 1863-1980. Charleston, WV: Charleston Newspapers, 1981.

Parsons, Elaine Frantz. Manhood Lost: Fallen Drunkards and Redeeming Women in the Nineteenth-Century United States. Baltimore: Johns Hopkins University Press, 2003.

Parsons, Stanley, et al., eds. US Congressional Districts and Data, 1843-1883. New York: Greenwood Press, 1986.

-_-_. US Congressional Districts and Data, 1883-1913. New York: Greenwood Press, 1990.

Pickett, Deets., ed. The Cyclopedia of Temperance, Prohibition and Public Morals. New York: Methodist Book Concern, 1917. 
Pierce, Patrick A. and Donald E. Miller. Gambling Politics: State Government and the Business of Betting. Boulder, CO: Lynne Rienner Publishers, 2004.

Rice, Otis and Stephen Brown. West Virginia: A History, $2^{\text {nd }}$ ed. Lexington: University Press of Kentucky, 1993.

Riddel, Frank S. The Historical Atlas of West Virginia. Morgantown: West Virginia University Press, 2008.

Sears, David O. and Jack Citrin. Tax Revolt: Something for Nothing in California. Cambridge, MA: Harvard Press, 1982.

Spooner, Walter W., ed. The Cyclopedia of Temperance and Prohibition: A Reference Book of Facts, Statistics, and General Information on All Phases of the Drink Question, the Temperance Movement, and the Prohibition Agitation. New York: Funk and Wagnalls, 1891.

Stafford, Thomas. Afflicting the Comfortable: Journalism and Politics in West Virginia. Morgantown: West Virginia University Press, 2005.

Stewart, Bruce. Moonshiners and Prohibitionists: The Battle over Alcohol in Southern Appalachia. Lexington: The University Press of Kentucky, 2011.

Szymanski, Ann-Marie. Pathways to Prohibition Radicals, Moderates, and Social Movement Outcomes. Durham, NC: Duke Press, 2003.

Thomas, Jerry. An Appalachian New Deal: West Virginia in the Great Depression. Morgantown: West Virginia University Press, 1998.

Timberlake, James H. Prohibition and the Progressive Movement. Cambridge, MA: Harvard University Press, 1963.

Tindall, George Brown and David Emory Shi. America: A Narrative History, Volume Two, $7^{\text {th }}$ ed. New York: W.W. Norton and Company, 2007.

Vizetelly, Frank H., ed. The New International Year Book: A Compendium of the World's Progress for the Year 1932. New York: Funk and Wagnalls Company, 1933.

Wade, Herbert Treadwell., ed. The New International Year Book: A Compendium of the World's Progress for the Year 1930. New York: Dodd, Mead, and Company, 1931.

Weiner, Deborah R. Coalfield Jews: An Appalachian History. Urbana: University of Illinois Press, 2006.

West Virginia State Gazetteer and Business Directory, 1900-1901, Volume VII. Detroit: RL Polk and Company, 1900. 
West Virginia State Gazetteer and Business Directory, 1912-1913, Volume XIII. Detroit: RL Polk and Company, 1912.

Williams, John Alexander. West Virginia and the Captains of Industry. Morgantown: West Virginia University Press, 1976.

\section{Journal Articles}

Baker, Paula. "The Domestication of Politics: Women and American Political Society, 17801920.” The American Historical Review 89, no. 3 (June 1984): 620-647.

Brisbin, Richard A. and Patrick A. Pierce. "Casting the Dice: The Development of Legalized Gambling Policy in West Virginia." The West Virginia Public Affairs Reporter 25, no. 1 (May 2008): 2-18.

Bush, Carletta H. "Religious Fervor in the Fairmont, WV Field: Calls for Revival in the Coal City, 1908-1919." Unpublished article. www.are.as.wvu.edu/cbush.htm.

Fox, Hugh F. "The Saloon Problem." Annals of the American Academy of Political and Social Sciences, Volume 32, Regulation of the Liquor Traffic (November 1908): 61-68.

Howe, Barbara H. “West Virginia Women's Organizations, 1880s-1930s or 'Unsexed Termagants . . Help the World Along." West Virginia History 49, no. 7 (1990): 81102. www.wvculture .org.

Jackson, J.C. "The Work of the Anti-Saloon League." Annals of the American Academy of Political and Social Sciences, Volume 32, Regulation of the Liquor Traffic (November 1908): 12-26.

Jacobs, James Henry. “The West Virginia Gubernatorial Election Contest, 1888-1890.” West Virginia History 7, no. 3 (1946). www.wvculture.org.

Platania, Joseph. "West Virginia's State Stores: a Legacy of Prohibition." Goldenseal 25, no. 1 (Spring 1999): 46-47.

\section{Theses and Dissertations}

Garrett, Thomas A. "An Economic Analysis of State Lotteries in America.” Ph.D. diss., West Virginia University, 1998.

Lockard, E. Kidd. "The Temperance Movement in West Virginia.” M.A. Thesis, West Virginia University, 1937.

Thurston, Karina. "Lenna Lowe Yost, Temperance, and the Ratification of the Women's Suffrage Amendment by West Virginia.” M.A. Thesis, West Virginia University, 2009. 
Tucker, Gary J. "William E. Glasscock: Thirteenth Governor of West Virginia." Ph.D. diss., West Virginia University, 1978.

\section{Websites}

www.odmp.org/agency/5583-west-virginia-department-of-prohibition-west-virginia.

www.uselectionatalas.org.

www.wvabca.com. 